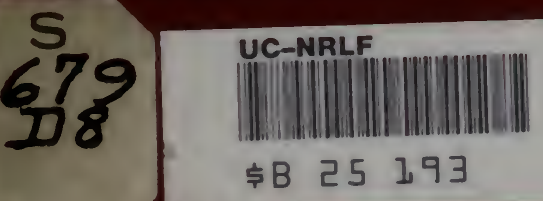

\title{
HOW TO USE
}

RED CROSS DYNAMITE enencis

DU PONT CO. 

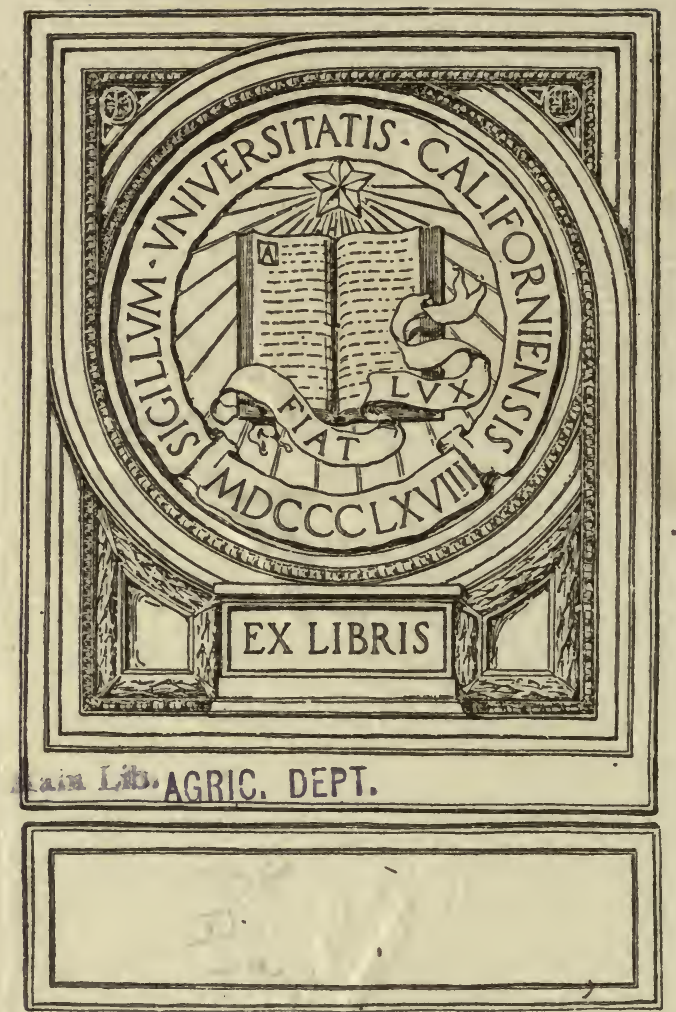
Digitized by the Internet Archive in 2007 with funding from Microsoft Corporation 


\section{+ RED CROSS DYNAMITE}

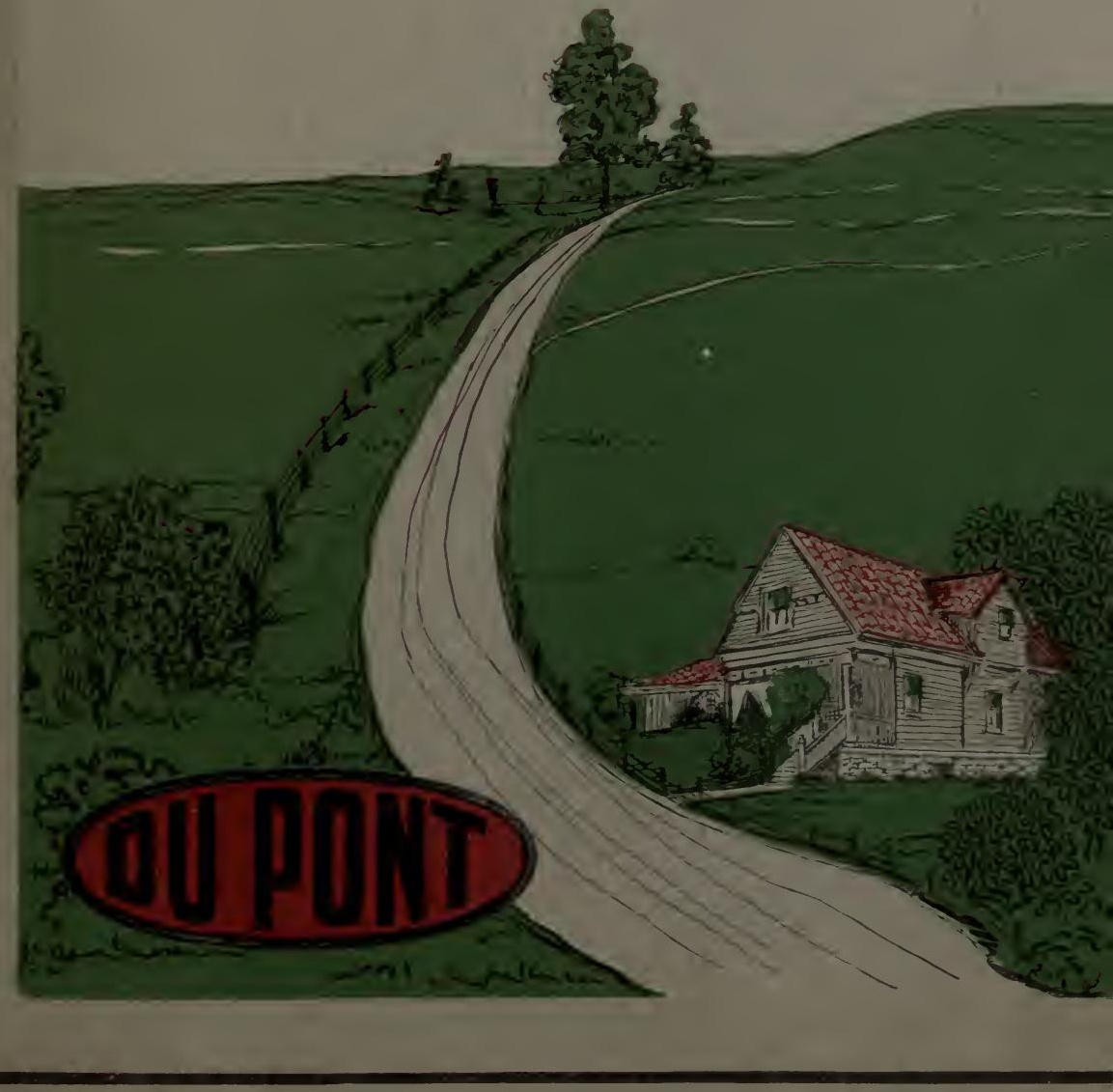




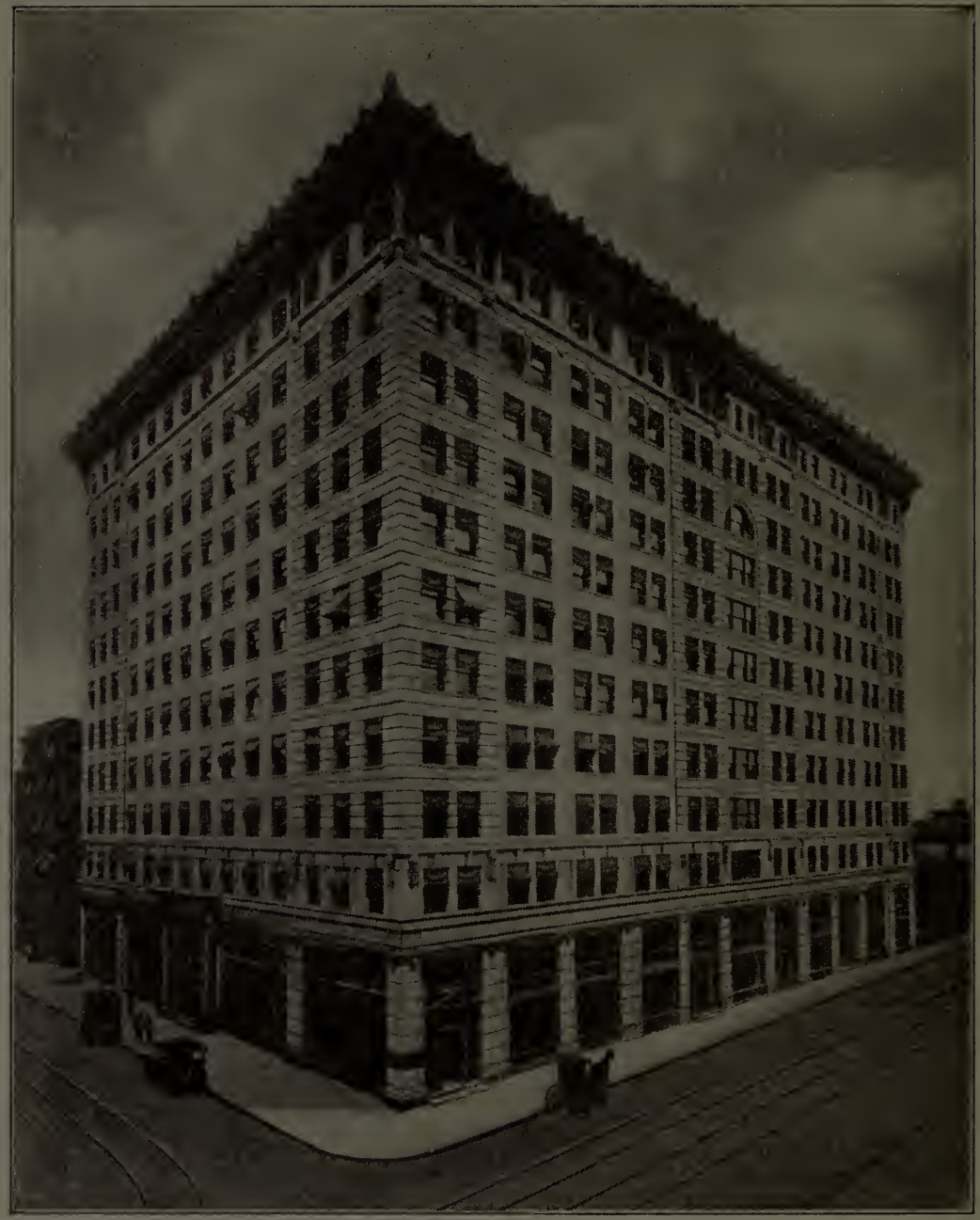

\section{E. I. DU PONT DE NEMOURS POWDER COMPANY} ESTABLISHED 1802 HOME OFFICE: WILMINGTON, DEL.

BRANCH OFFICES

BIRMINGHAM. ALA. BOSTON. MASS. BUFFALO, N.Y. CHICAGO, ILL. CITY OF MEXICO DENVER, COLO. DULUTH, MINN. HAZLETON, PA. HOUGHTON, MICH.
HUNTINGTON, W. VA. JOPLIN, MO. KANSAS CITY, MO. MEMPHIS, TENN. NASHVILLE, TENN. NEW ORLEANS, LA. NEW YORK, N. Y. PHILADELPHIA, PA. PITTSBURG, KAN.
PITTSBURGH. PA. PORTLAND, ORE. SALT LAKE CITY, UTAH SAN FRANCISCO, CAL. SCRANTON, PA. SEATTLE, WASH. SPOKANE, WASH. SPRINGFIELD, ILL. ST. LOUIS, MO.

We have magaxines and carry stocks at all important trade centers throughout the United States and are in position to fill orders promptly through your dealer. 


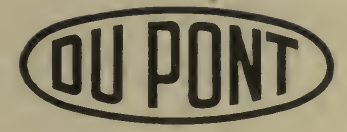

\section{FARMER'S HANDBOOK}

INSTRUCTIONS

IN THE USE OF

DYNAMITE

FOR

CLEARING LAND

PLANTING AND

C.UL T IVA T IN G

TREES, DRAIN-

AGE, DITCHING

AND SUBSOILING

Copyright, 1912

E. I. du Pont de Nemours Powder Co.

Established 1802

Wilmington, Delaware 


\section{.369}

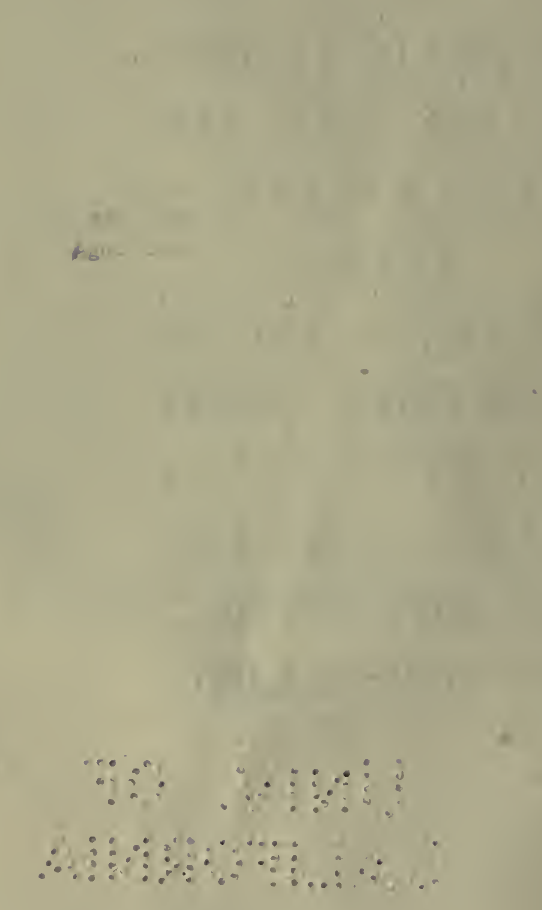

$1 ! 150$. 


\section{N D E X}

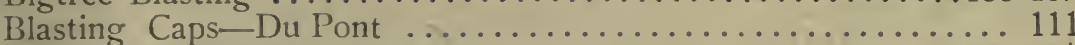

Blasting Circuits .................................. 146

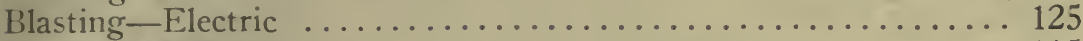

Blasting Machines ............................ 115

Blasting-Principles of $\ldots \ldots \ldots \ldots \ldots \ldots \ldots \ldots \ldots \ldots \ldots \ldots \ldots \ldots \ldots \ldots \ldots$

Blockholing Boulders ............................ 140-141

Bore Holes-Location of in Stump Blasting.............. 127

Boulder Blasting ......................... 140

Boulder Blasting-Charges for ................. 143

California Hardpan Blasting . ...............71, 87, 153

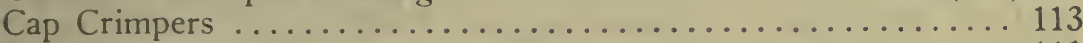

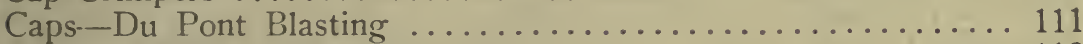

Caps and Fuse-Preparing . . .................... 119

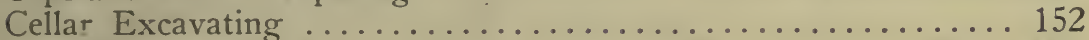

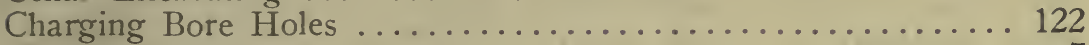

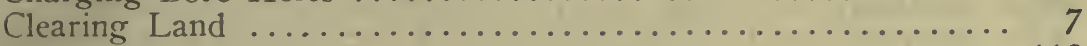

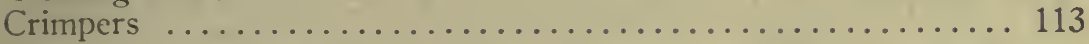

Deep Plowing-Increases Crops ................ 77

Ditch VViring .......................... 146

Ditches-Cross Section of Blasted.................. 144

Ditch Blasting Without a Blasting Machine............. 147

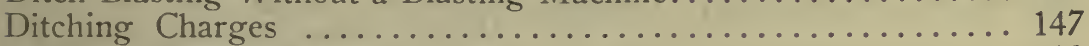

Ditching Cranberry Bogs ...................... 39

Ditching Diagrams .......................... 1446-149

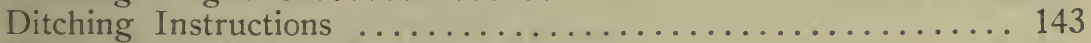

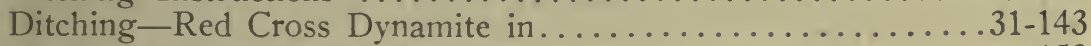

Drainage-Charges for Deep ...................... 150

Drainage Instructions . . . . . . . . . . . . . . . . . . . 149

Drainage-Frog Ponds ...................... 149

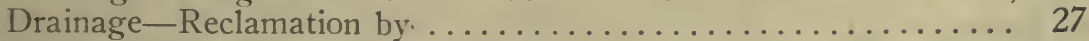

Drainage-U. S. Map....................... 24

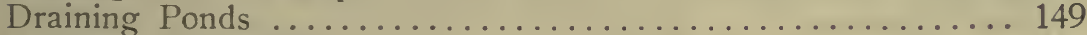

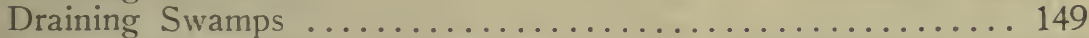

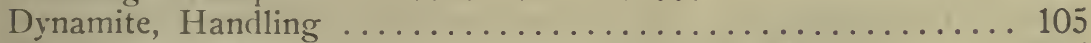

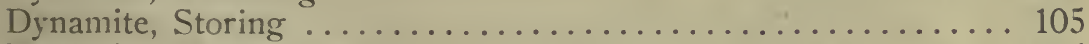

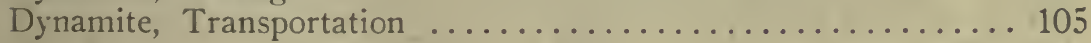

Electric Blasting ........................... 125

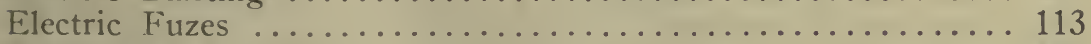

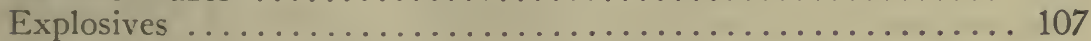

Fertility of Soil-Depths of $\ldots \ldots \ldots \ldots \ldots \ldots \ldots \ldots \ldots \ldots 48$

Fertilizers-Effects of Subsoiling on................ 89

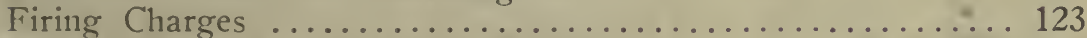

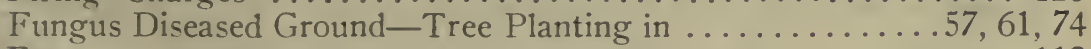

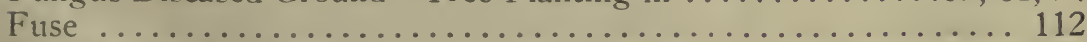

Fuse Lengths-Table of ...................... 140

Fuzes-Electric ............................. 113 


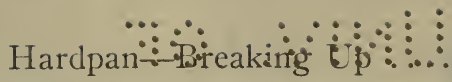

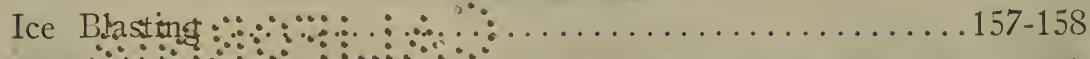

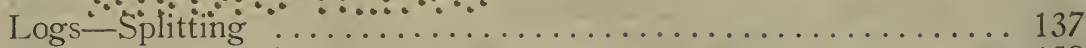

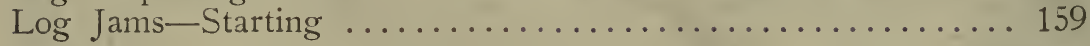

Mudcapping Boulders ...........................

Orcharding-A Revolution in ....................... 45

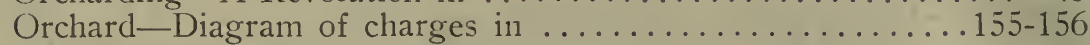

Orchard Rejuvenation ........................... 74,155

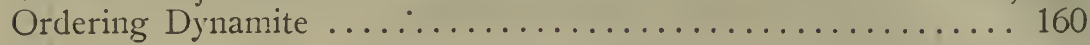

Plant Growth-Principles of $\ldots \ldots \ldots \ldots \ldots \ldots \ldots \ldots \ldots \ldots$

Planting Trees $\ldots \ldots \ldots \ldots \ldots \ldots \ldots \ldots \ldots \ldots \ldots \ldots \ldots \ldots \ldots \ldots \ldots \ldots \ldots, 154-157$

Pond Drainage ................................. 149

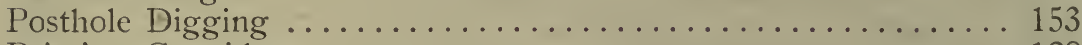

Priming Cartridges .................................... 120

Propagated Blast ............................. 147

Red Cross Dynamite-Safety of ................... 108

Road Building ................................... 151

Root Penetration-Depth of $\ldots \ldots \ldots \ldots \ldots \ldots \ldots \ldots \ldots . . .61$

Second Growth Stumps-Blasting .................. 137

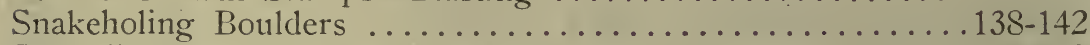

Spreading Root Stumps-Blasting ....................... 129

Stump Blasting-Instructions for................. 127

Stump Blasting-Table of Charges-Western Fir Stumps....... 133

Western Pine Stumps...... 133

Western Cedar Stumps..... 133

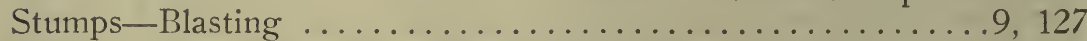

Stump Pullers-Red Cross Dynamite Superior to ............ 11

Stumps-Splitting ............................ 137

Subsoil-Best Time to ................................ 104

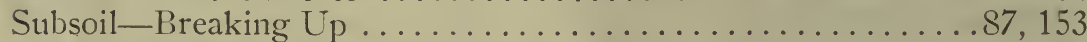

Subsoil Charges-Table of ..................... 87

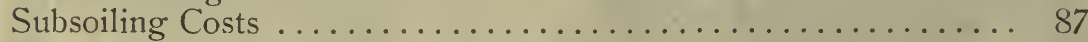

Subsoiling-Duration of .......................... 102

Swamp Drainage ................................ 149

Tamping Bore Holes ............................ 122

Tap Rooted Stumps-Blasting......................... 128

Terracing Land to Stop Soil Washing .................. 91

Thawing Dynamite ..................................... 110

Tools for Agricultural Blasting ......................... 116

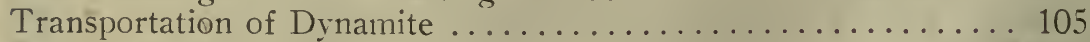

Tree Planting .............................. 43, 154-157

Tree Planting-How To Do It . . . . . . . . . . . . . . . . . . 69. 154

Tree Planting With Red Cross Dynamite .................. 43-154

Trees-Felling .................................. 137

Turpentine Industry - Red Cross Dynamite in the ......... 21

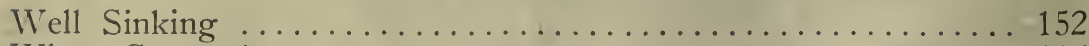

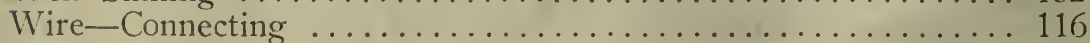

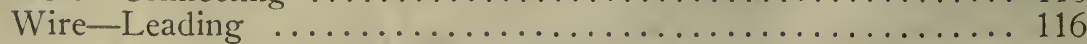




\section{HOW TO READ AND USE}

\section{$\underline{\underline{\text { THIS BOOK }}}$}

This book has a double purpose, namely, to present the advantages of using Red Cross Dynamite on the farm, and to give detailed instructions as to the best methods of using same.

Every farmer, orchardist or other person interested in a farm or orchard should read this book from cover to cover at least once, in order to get a general idea of the utility of Red Cross Dynamite on the farm, and how to handle it safely, economically and efficiently.

Next consider how you could use Red Cross Dynamite to advantage on your farm or in your orchard. Then figure out how much Red Cross Dynamite you need and order it at-least three weeks in advance of the time you expect to use it. Then spend your spare time during those three weeks in carefully studying all of the instructions that pertain to the particular uses of Red Cross Dynamite that apply to your proposed work.

It is especially necessary that you become thoroughly familiar with the method of priming Red Cross Dynamite cartridges and of charging bore holes.

A great deal of information can also be obtained by reading the letters from farmers and orchardists who have had experience in the use of Red Cross Dynamite, as their descriptions of methods employed contain many good practical points.

It must be borne in mind that to the average farmer, dynamite is something absolutely new which he has never even seen and knows practically nothing about. He cannot therefore do too much reading about Red Cross Dynamite so that when he does handle it he will not injure himself through ignorance or carelessness, but will use it intelligently, safely and profitably. 


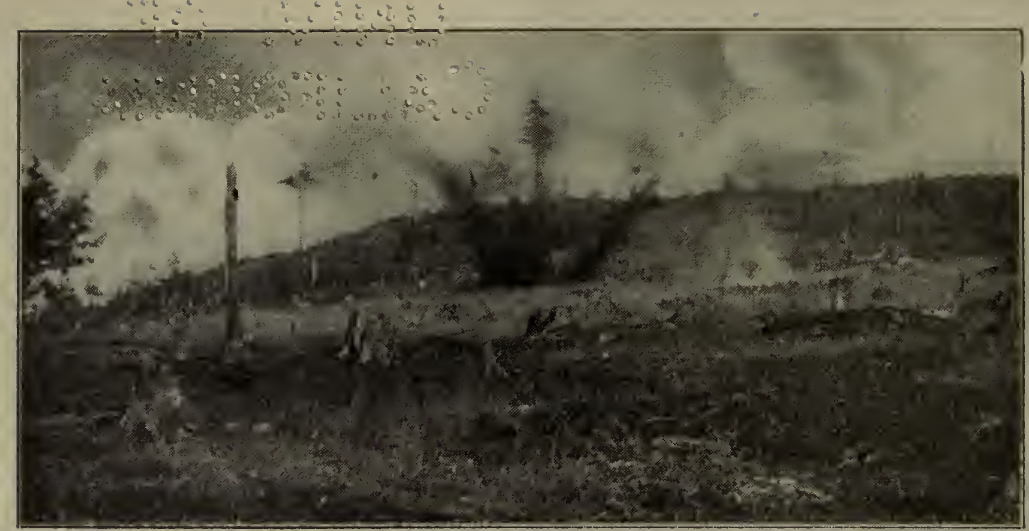

FIG. I.-WASTE LAND NEAR HIBBING, MINN. FARM OF G. G. HARTLEY

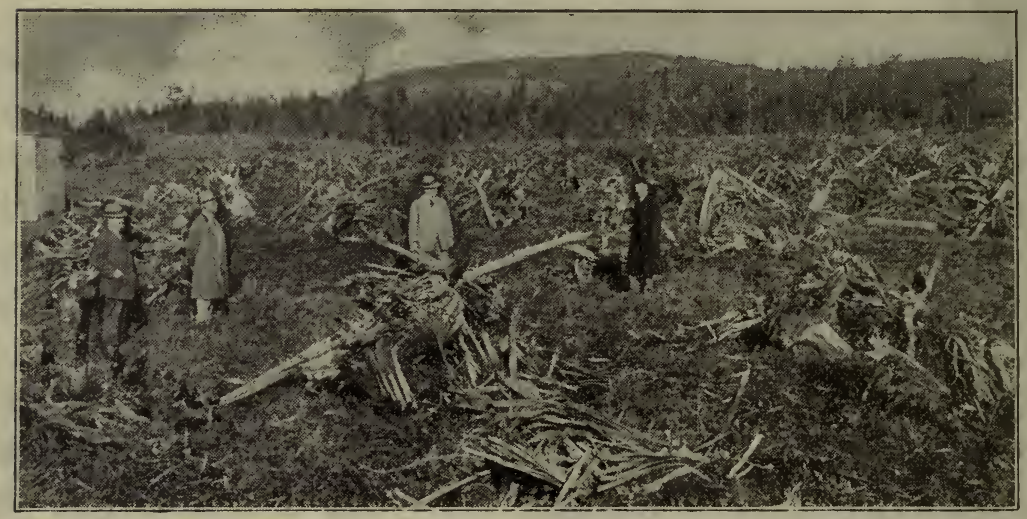

FIG. 2.-SAME LAND WITH STUMPS BLASTED

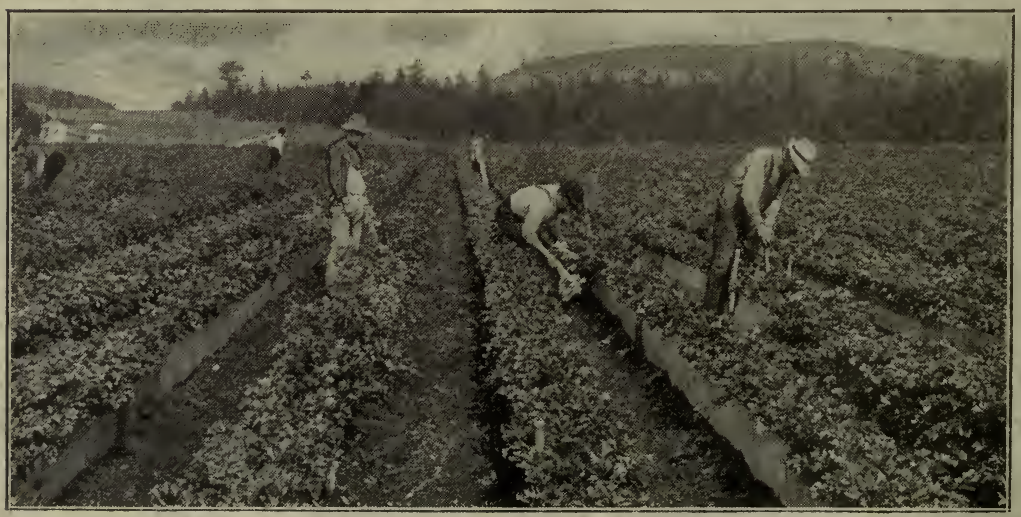

FIG. 3.-SAME LAND 10 MONTHS AFTER BLASTING, YIELDING $\$ 800.00$ WORTH OF CELERY PER ACRE 


\section{Clearing Farm Land With Red Cross Dynamite}

Ever since the first white man started a permanent settlement in this country, the transformation of forests into farms has been carried on continually and at an ever-increasing speed. So great is the magnitude of the land clearing operations today, so large is the annual expenditure in this work, that it has become a factor of prime importance in the national economy and the necessity for a careful study of all its phases to the end of improving the varicis methods now in practice, is everywhere recognized.

If, after the passing of the wood chopper and the sawmill, the land were ready for the plow, there would be no problem to solve; but a great area covered with stumps, thirty, fifty, a hundred, two hundred to the acre-with a number of boulders scattered here and there-is very far from a crop-bearing condition.

When the farmer of the old school already had more acres than he could cultivate- $\mathrm{a}$ few acres that needed clearing of stumps and boulders - a few acres that might have been drained-a few acres that were especially adapted to growing a particular crop but hardly seemed worth while to "bother with"-these acres naturally were neglected.

Even some of the new school of farmers, pledged to the new methods of cultivation, are leaving those old, obstructing features of soil surface to the elements, accepting the fact that, as they have never been removed, it isn't worth while at this late day to spend time and money on them.

Now, READER, does not the above apply to your case? Haven't you one particular field containing stumps and boulders which is an eye-sore which you think it is hardly worth while to bather with? Have you ever stopped to consider the cost of the damage to your implements these obstructions have caused you? F-ave you ever reasoned that you have been losing yearly HALF A DOLLAR'S worth of produce which might have been grown in the ground occupied by each stump or boulder, and cultivated with less effort than is required to dodge them? We ask you to reason these points out in order that you may recognize the DOLLARS AND CENTS which you could today have deposited in your bank, if you had used a little Du Pont Red Cross Dynamite for their removal.

You undoubtedly realize that in growing "two blades of grass where only one grew before" you are receiving from the same amount of labor and from the same investment of dollars, an increased yield of $100 \%$-a premium which accrues to the ledger balance uncler the general heading of "Enterprise."

You must also appreciate that an acre of land which lies nonproductive for a season is comparable with its money value buried under a stone, or with its value in machinery lying idle under the roof of a manufacturing plant.

Therefore, to make every acre of your farm profitable becomes of first importance, because land that lies waste is taxed and has chargeable to it year after year its proportionate fixed expense.

In this section we endeavor to bring before you the many advantages to be clerived by clearing your farm of stumps and boulders by the use of Du Pont Red Cross Dynamite. 


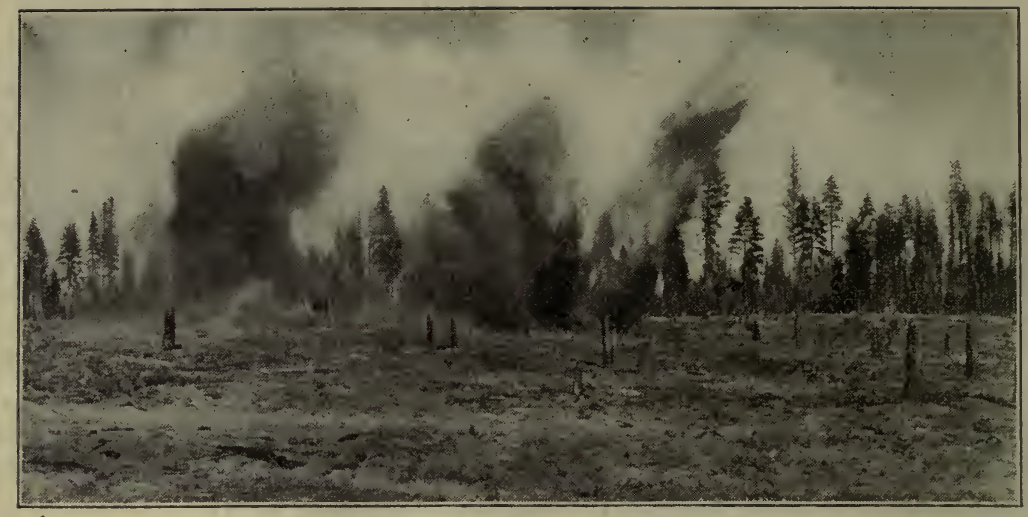

FIG. 4.-ARCADIA ORCHARD CO., DEER PARK, WASHINGTON, CLEARING THE LAND

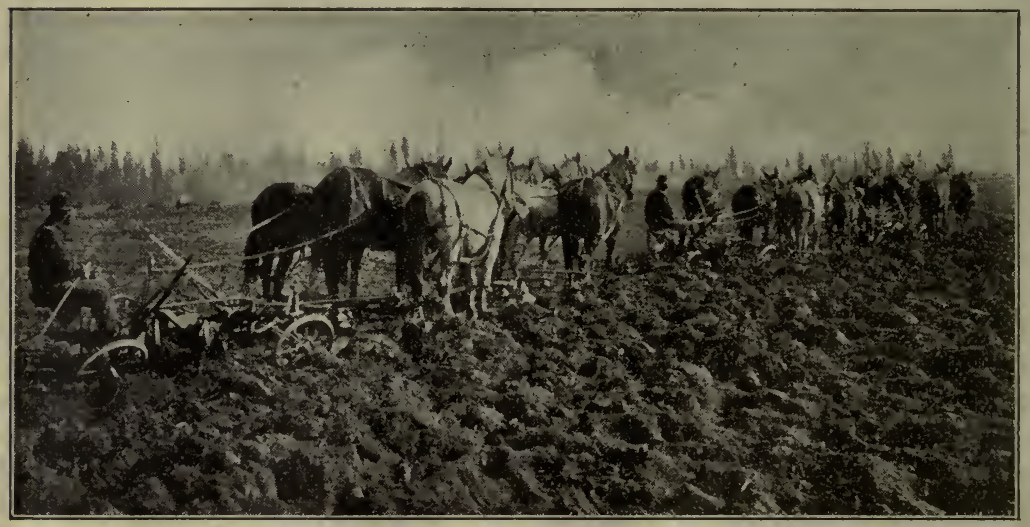

FIG. 5--SAME. FIRST PLOWING OF CLEARED LAND

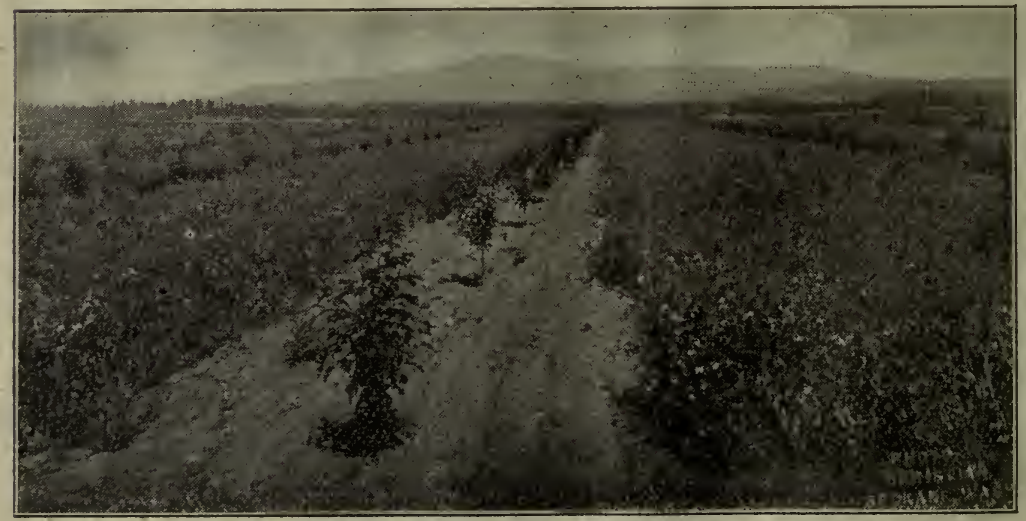

FIG. 6.-SAME. PLANTED WITH FRUIT TREES AND PEAS 


\section{Why Red Cross Dynamite is the Best Stump Remover}

When Red Cross Dynamite is properly used, stump or boulders are not only blasted out of the ground but are broken into pieces which can be easily handled.

\section{Red Cross Dynamite a Money and Labor Saver}

Since I learned how to use dynamite, I have discarded the stump puller entirely, and will not use it again, as I figure dynamite is a money and a labor saver, as well as a time saver, and if we are to make any headway in this section clearing land, we must use dynamite or we will not have farms until we are old men.

The stumps often average 100 to the acre, and to get these out with a stump puller would require an enormous amount of labor and in addition the wear and tear on harness, and strain and chances of injuring horses must be considered. Dynamite removes all these difficulties, and also can be used under conditions where it would be impossible to employ team labor.

Stumps when split with dynamite burn easily. Stumps pulled with a puller have to be repiled sometimes several times, in order to get them to burn. Besides the extra labor involved in burning, the humus is entirely burnt out of the soil adhering to the roots of the stumps, and this loss is a large one, as we are beginning to learn.

The use of dynamite for blasting boulders is becoming very general, and is so cheap as to make the use of other means of disposing of them ridiculous.

For ditch digging in wet and low places, dynamite certainly is the thing, as it cheapens the cost of doing the work, permits of ditching being done where it is impossible to get in with machinery and horses, and also allows of the work being done in a short time.

Last year (1911) I used 1,300 pounds of Red Cross on about thirty-five acres and will use nearly as much this year, and cheerfully recommend it for land-clearing purposes.

$$
\text { JORGEN JUHL, Askov, Minnesota. }
$$

When a stump is properly blasted but little of the soil is thrown out with it, and it is not necessary to spend time and money clearing the earth from roots. Burning out stumps is an exceedingly slow and incomplete process and besides destroys the humus in the soil for many yards around so that several years of special fertilization of that spot is necessary.

Only a very small outlay is necessary at one time when Red Cross Dynamite is used, and two men can work at as little relative cost as a dozen or a hundred.

\section{Red Cross Beats Stump Puller in Many Ways}

The 700 stumps on the ten acres that I have cleared have been blasted with dynamite, with the exception of about two acres, which was done with a team and stump puller. I find the dynamite so much cheaper and better that I cannot afford to use a stump puller.

Dynamite will break the stump and leave it so that it can be handled, while a stump puller leaves it so large that it is impossible to handle without breaking. I consider the latter method entails an expense of about 50 per cent. more.

I also find that the stump is free from dirt when dynamite is used, which is not the case with a stump puller. I find that the ground works easier and is more productive where dynamite is used, as it shakes up the soil and breaks the hard soil under the stump which a puller will not do.

Also, for the boulders it cannot be beat, as one can remove a boulder in a few minutes, which a stump puller will not handle, and which has to be drilled and broken in pieces before it can be handled even if pulled from the ground.

I think a man and a box of dynamite will remove more stumps in a dav than two men and a team with a stump puller. 


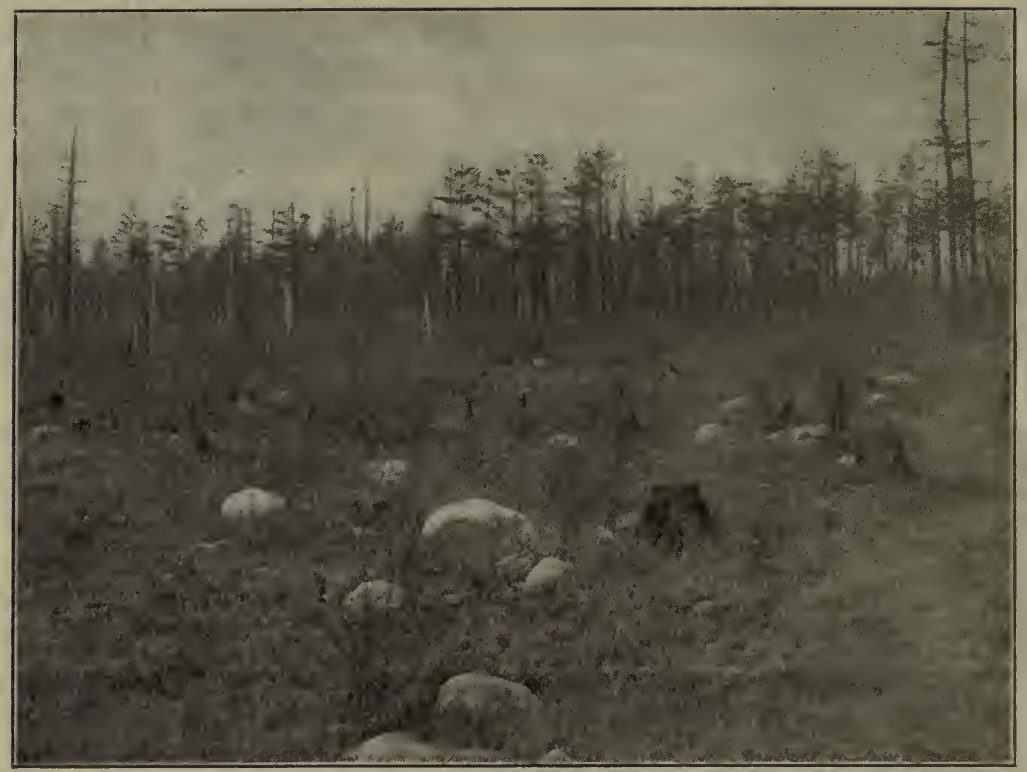

FIG. 7.-A TYPICAL PIECE OF WASTE LAND

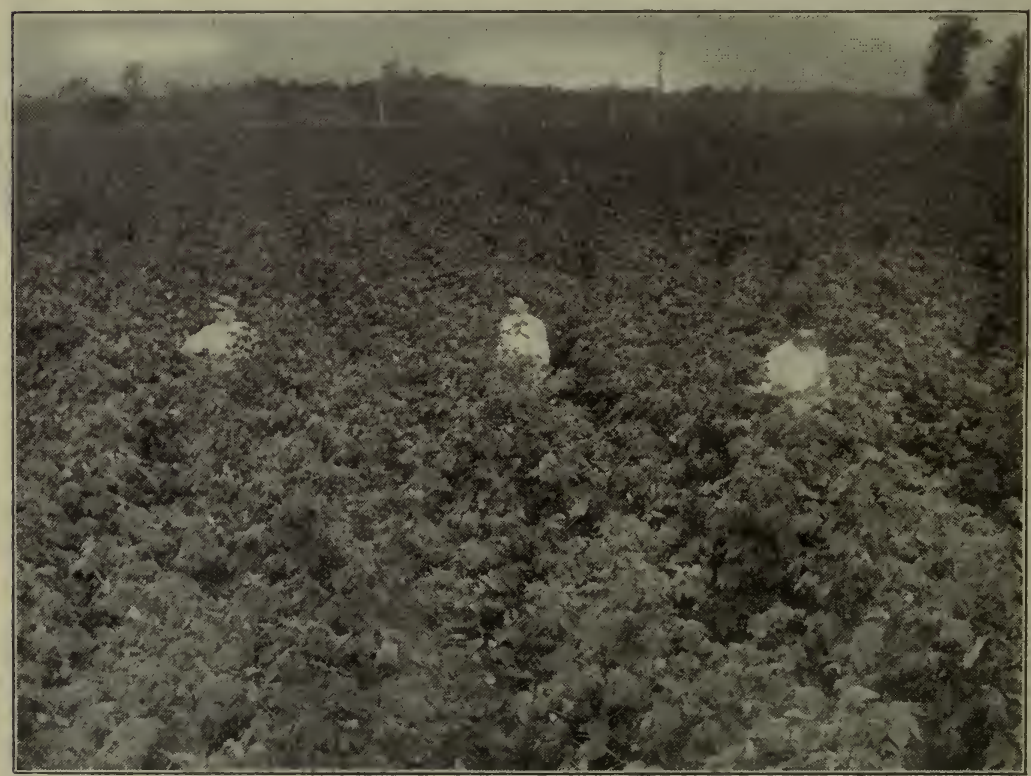

FIG. 8.-FINE COTTON ON RECENTLY CLEARED I.AND. PLANTATION OF H. J. MCELROY, CUBA, ALA. 


\section{Red Cross Superseding Stump Puller Everywhere}

It is a matter of considerable interest, to one who takes the trouble to investigate it, to see how Red Cross Dynamite is superseding the stump puller in land-clearing operations. Wherever the two methods have come into close competition, the latter has been completely vanquished. Says a prominent Farmers' Institute man, in an article in the Ninneapolis Farmers' Institute Annual for 1908: “After using the stump puller for years I have laid it aside and shall never take it to the field again, simply because I cannot afford to use it." We quote from the report of an Eastern Experimental Farm: "There is a contractor who has for a long time claimed that he can clear land much cheaper and better with a stump puller than with dynamite. We determined to have it proven to us and so signed a contract to have 10 acres cleared in 30 days. It is now 60 days and the stumps are partially out of about 2 acres. In fact the remaining roots are so numerous that it is almost impossible to plow. Dynamiters go in next week."

A bulletin from an Experimental Farm in the Lake States cut-over region, says: "Dynamite is now used almost exclusively by men who have "nade a study of clearing land. It is surely the quickest, easiest, and most practical way to remove stumps and boulders yet known."

Without commenting on such unquestioned and authoritative statements, let us consider a few of the advantages obtained by using Red Cross Dynamite.

1. FRAGMENTATION AND DISPOSAL. Dynamite not only removes the stump but also breaks it into pieces which are easily handled. When stumps are pulled, they cannot be disposed of otherwise than by burning in the field. Often this is rendered difficult by the dirt which pulls up with and remains attached to the stump. Dynamite so shatters the stumps that all dirt is removed and a great quantity of excellent fuel is gotten from the fragments.

\section{$\$ 30.00$ Worth of Red Cross Dynamite Increases Value of Farm From $\$ 25.00$ per Acre to $\$ 75.00$}

I have recently finished clearing out oak, chestnut, poplar and walnut stumps ranging from eight inches to eight feet in diameter, on all of which I used 40 per cent. Red Cross Extra Dynamite.

This work cost me, including the labor, on an average of 30 cents per stump or $\$ 30$ per acre; while by any other method the work would have cost at least 50 cents per stump or $\$ 50$ per acre. Furthermore, this land was worth but $\$ 25$ per acre before stumping it, while its present value is from $\$ 60$ to $\$ 75$.

These stumps were mostly large; some were eight feet across, but I took them out with ten and twelve sticks of dynamite. I don't think much of the stump puller; the ones on which the stump puller was used had to be dynamited before I could remove them, using as high as five sticks on some to get them torn up. We have tried most all ways of getting them out and find Red Cross Dynamite the best. 


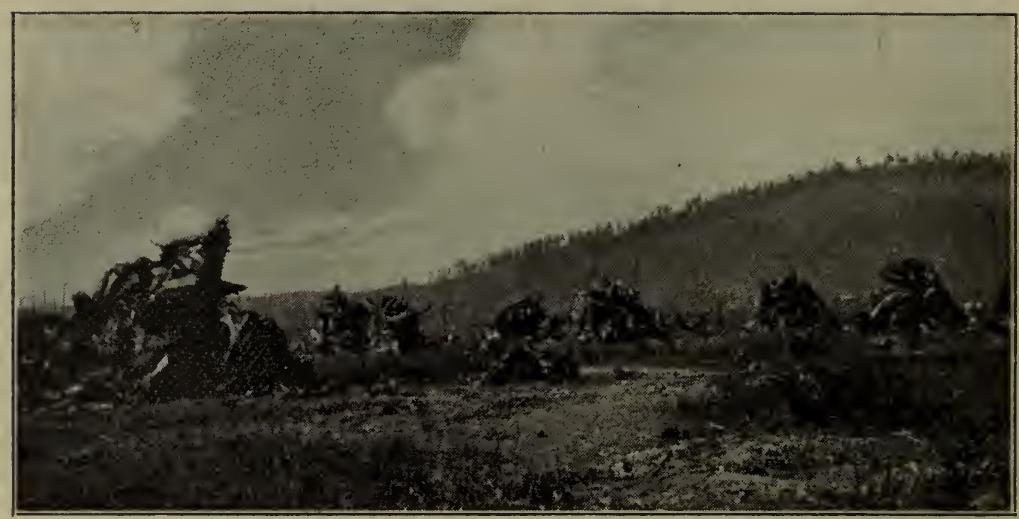

- FIG. 9.-BLASTED STUMPS. MICHIGAN LAND AND LUMBER CO., CAREYWOOD, IDAHIO

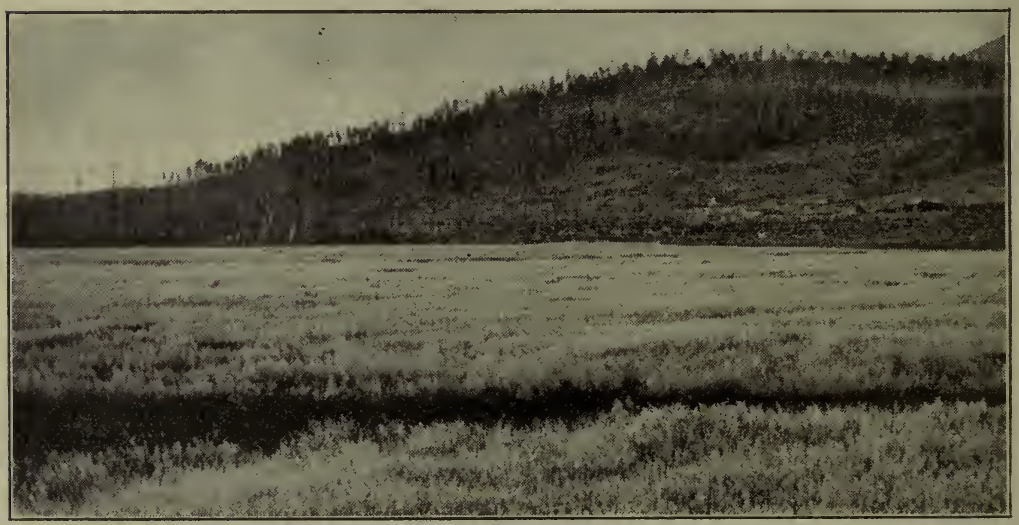

FIG. I0.-SAME LAND]BEARING FINE CROP OF OATS

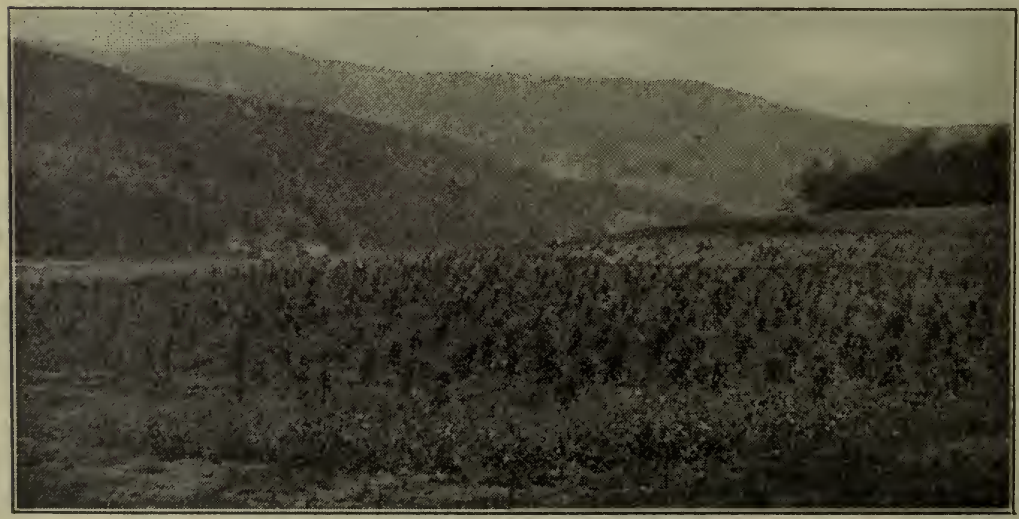

FIG. $x$. - CORN ON CLEARED LAND, 75 BUSHELS TO ACRE, ONE YEAR AFTER CLEARING. FARM OF J. C. LOOKER, RIXFORD, PA. 
2. FOR SWAMP WORK. In swampy or wet grounds any other method of stump removal is out of the question. Red Cross Dynamite will do the work anywhere man can place it.

\section{Land Cleaned, Drained and Subsoiled at One Operation and at One Cost}

I have had quite some experience with dynamite for blasting stumps and have had great success. Altogether, I have cleared about twenty acres of 600 gum and cypress stumps from one to five feet in size, using Du Pont Red Cross 40 per cent. Dynamite.

Dynamite is the cheapest way to clear land by half and more, and if it is done right and in tight land, it loosens it up so water sinks and the air gets in and makes it produce much better.

$$
\begin{aligned}
& \text { W. L. WOOD, } \\
& \text { Morrilton, Ark. }
\end{aligned}
$$

3. SPEED OF OPERATION. One man with a reasonable amount of skill should be able to blast out THREE stumps during the time employed in taking one out by any other means, as there is no waste of time and labor cost in cutting the roots, breaking of machinery, etc.

\section{Why Red Cross Dynamite is Faster Than Stump Puller}

I have used both the stump puller and Red Cross Dynamite, but have abandoned the stump puller because it costs too much in labor and breakage, and, worst of all, it is too slow. Try as you may, you will be compelled to dig out and cut the biggest roots, as there are no stump-pullers made strong enough to pull stumps of any size without digging and cutting anchor roots.

Nature made the stump and anchor roots on which the tree stood sufficiently strong to resist any ordinary storms, and it is but rarely that you see a tree uprooted by anything less than a tornado. Now if we are going to uproot or remove this stump by a pull, we will have to get one stronger than any it has ever before been subject to, before the tree was cut. In other words, we will have to make a chain stronger than the tempest, a cable rope and machinery stronger than the winds, not to mention the rules of leverage, as the wind gains power on the stump by the height and amount of limbs on the tree. The stump puller does not have any advantage in that respect, as it should remove the stump by a direct pull, and an ordinary stump will resist an enormous strain.

Dynamite works to the contrary; its work is underneath the stump, with a sudden jerk and an explosion hursting the roots before they have a chance to resist any power.

As to comparison of costs in the two methods: With a puller, it requires about three men, one team, and costly repairs. A machine, no matter how strongly made, when subjected to violent strains will weaken and some parts of it will break. Now, a good day's work with puller and gang (Io hours), three men at $\$ 2-\$ 6$; one team at $\$ 1$, totaling $\$ 7$ per day besides repairs, will remove not over fifteen stumps, more often not over ten.

With dynamite, the same amount of men and other expense will remove in the same length of time at least forty stumps, and, besides removing the stumps and breaking them up into pieces more easily handled, will also, while it blasts a stump, break up hardpan if any exists.

$$
\begin{aligned}
& \text { CLAUD HANSEN, } \\
& \text { Jamestown, Kan. }
\end{aligned}
$$




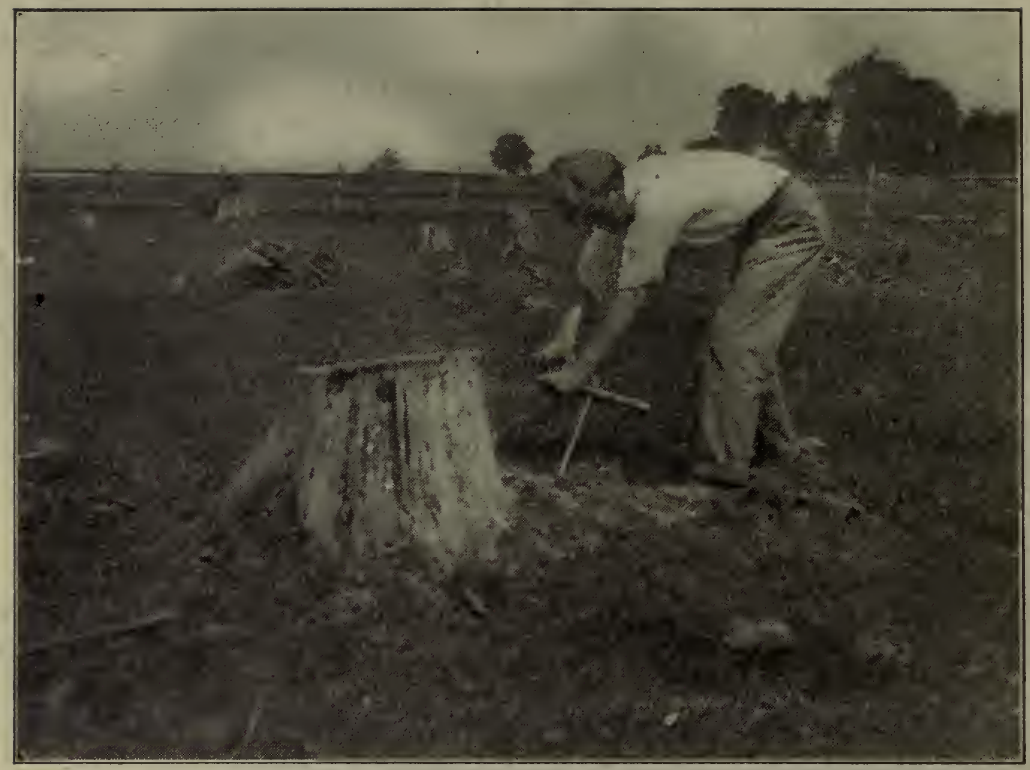

FIG. 12.-BORING HOLE UNDER STUMP WITH DIRT AUGER. THIS IS NOW USUALLY DONE WITH A PUNCH BAR

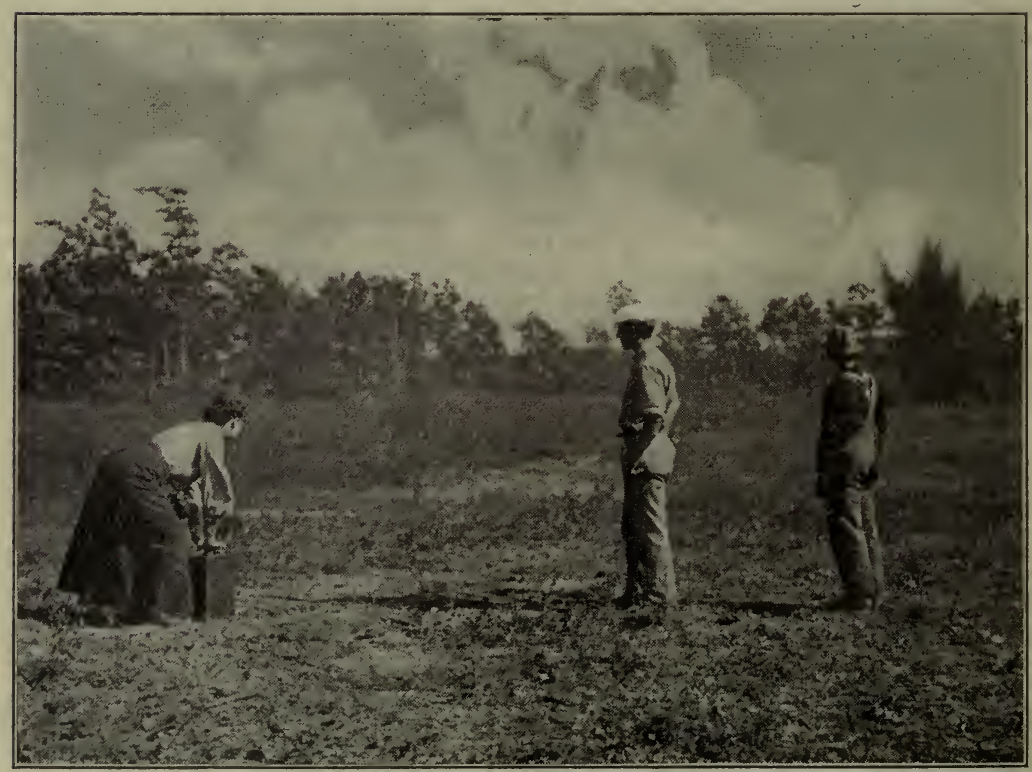

FIG. I3.-WOMAN OPERATING BLASTING MACHINE 
4. COST. Taking into consideration initial expense, labor, teams. replacing broken machinery, and time wasted, Du Pont Red Cross Dynamite is at least twice as economical as any other method yet devised.

Stump pullers are costly. A good quality one-horse machine cannot be secured for less than $\$ 100$ to $\$ 125$. One horse, a man, and a boy are needed to operate it. The cables of this type, being rather light, cannot be used for heavy work, which oftentimes necessitates the services of a heavier machine. Such a one would cost from $\$ 175$ to $\$ 250$ and would require a team and at least three men to work it. The initial cost then is prohibitive to many farmers, for a machine of this sort is not one which will be used year after year, like a harvester. After the stumps are removed, it is no longer of use, and you have doubtless seen, on more than one occasion, an old puller, slowly being converted into iron rust, in some far off field corner. Wages, cost of repairs, delays caused by the breakages, which inevitably occur, with resulting loss of time on the part of a crew of men, all these join to bring the cost of operation up to a high figure.

Large stumps have to be split with explosives and boosened for the puller. This necessitates the handling of each piece separately, taking considerable time. A little Red Cross Dynamite put under that stump would have entirely removed it and quicker too. The initial cost of dynamite is trifling and it may be purchased as needed, so that there is no depreciation in value. One man can blast stumps as well as two, so that every farmer can do his own work if he wants to without hiring extra men.

Stump pulling machines are not furnished with sweep or bedpieces, which the farmer must make for himself. There is need for strong cables, spreader chains, whiffletrees, hooks, and like details for the strain upon these parts is enormous. He must have at hand material to replace any of these when broken, and a set of axes and mattocks to assist the machines. Where the ground contains stone or gravel, the latter become rapidly dulled, and require frequent sharpenings. In some parts of the South it is the custom to use both a yoke of oxen and a team of mules with the machine, the first to do the actual pulling, and the last to move the machine from place to place. The blaster needs very few tools and they are easily carried.

Because of the different amount of work done by dynamite and by stump puller, in a given period of time, it is impossible to compare the costs of each per day, at least directly. It is more feasible to compare the cost per acre or per averaged-sized stump, because blasters seldom keep accurate accounts of the different items, and owners of pullers are likewise neglectful; it is not easy to get hold of any accurate figures. We are able to furnish statistics as to the relative costs of the two methods in the Southern Pine regions. We are indebted to the Mississippi Agricultural Experiment Station, for the basis of the computation. 


\section{Cost With Mechanical Puller}

Puller and two yoke of oxen, per day.......\$5.00

Three men at $\$ 1.50$ per day.............. 4.50

Total....................... \$9.50

Number of stumps averaged, per day..........40

Cost per stump $1-40$ of $\$ 9.50=\ldots \ldots \ldots \ldots \ldots \ldots .24$

\section{Cost By Blasting}

(Labor figured at $\$ 1.50$ per day)

Cost of boring stump.............. 025

Cost of charge of dynamite (average)....... 07

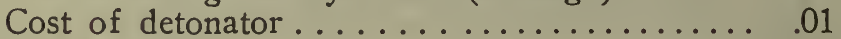

Cost of fuse ........................

$\$ .115$ or $11 \mathrm{c}$.

This indicates a saving of at least 12c. per stump by the use of dynamite. Figuring 100 stumps to the acre, which is certainly not excessive, the saving will be $\$ 12.00$ per acre.

The extremely low cost of blasting a stump is further illustrated by these figures which we quote from the Engineering Contracting Magazine of May 13, 1908. They refer to the blasting of 3,500 stumps 18 inches to $71 / 2$ feet in diameter, averages, of course, being given. This work was done on Long Island.

\section{Cost per Stump}

Labor (at $\$ 2.00$ per day) ................ $\$ .059$

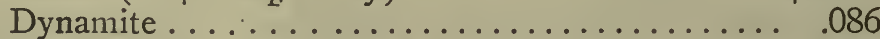

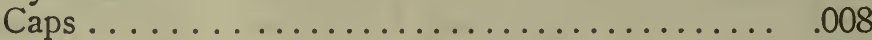

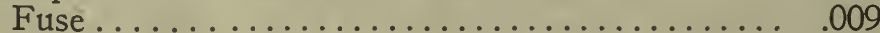

Total cost per stump..............\$.162

By preparing the charges the evening before, one man blasted 100 stumps in one day, thus reducing the labor item to a little over 2c. per stump. It will be observed that these were very large stumps. Of course, the skill of the blaster counts for much. The more care and judgment is used, the more economical the blasting.

\section{Dynamite Cheaper Than Stump Puller}

I blasted from my property 1,000 white pine stumps averaging about two and a half feet, all of which were removed very successfully with Red Cross Dynamite.

This land was always unproductive prior to 1910 when I started to farm, but by removing these stumps I have reclaimed about eight acres, which were planted to corn and potatoes in 1910 and 1911.

I have approximately 7,000 more stumps on this property, all of which will be removed as quickly as possible, and it will be dynamite for me all the time, as I find its use easily one-half cheaper than it was possible to do this work with a team and stump puller.

We had a stump puller but sold it as we found that dynamite did the work easier, cheaper, and quicker and the results were better. 


\section{Stump Puller Discarded for Red Cross Dynamite}

During December, 1911. I used 40 per cent. Red Cross Dynamite for clearing white oak stumps ranging from two to three feet in diameter.

This work, labor and all, cost about 15 cents per stump or an average of $\$ 36.60$ per acre as compared with a cost of at least 35 cents per stump or $\$ 84$ per acre by using a stump puller. Another thing, the land was practically worthless, but after clearing it is valued at $\$ 90$ per acre.

There is no other method which can be compared with dynamite. I have a horse stump puller and yet I use dynamite in preference to the puller.

GEO. L. FISCUS, Egg Harbor, N. J.

\section{Dynamite Cheaper Than a Donkey Engine}

There was a piece of land on my property which I wished to clear. During the first week in March I moved about forty fir and cedar stumps with Red Cross (low freezing) Dynamite, 40 per cent.

This work cost me about $\$ 1$ per stump, a total of $\$ 40$. The stumps ranged from one-and-a-half to three feet in diameter, and would have cost $\$ 2.50$ per stump or a total of $\$ 100$, taken out by any other method.

I have quite a number of stumps to move this fall, averaging about three feet in diameter, and will certainly use Red Cross Dynamite.

There was a donkey engine working on my neighbor's place, but I beat it with my dynamite.

BURT P. WEISE, Carrolton, Wash.

\section{Finds Stumps an Expensive Luxury}

I removed ten acres of stumps last spring from a field that I put in corn, and six acres in the fall, which were put in wheat. I have made up my mind never to farm around stumps in the future, but to take them out with dynamite. If your readers think my judgment is not good I only ask them to give it a fair trial. I thought like a great many others that it was too expensive, but if you count loss of land where the stumps stand, loss of time in working around them, chances of spoiling young horses, causing sore shoulders, breakage of machinery, worry and inconvenience of the man who does the work, you will find it economical rather than expensive.

HOMER C. SMALL, Martinsburg, W. Va.

\section{Red Cross Removes 10,000 Stumps; Trebles Land Value}

During the last four years I have blasted about 10,000 pine, poplar, elm, oak, and spruce stumps, ranging from 10 inches to 4 feet in size, on all of which 40 per cent. Red Cross Dynamite was used.

I cleared about 100 acres at a cost of about $9 \mathrm{r} / 2$ cents per stump, or $\$ 10$ per acre and feel very certain that by any other method this work would have cost at least 25 cents per stump or $\$ 25$ per acre.

Before removing these stumps this land was worth about $\$ 16$ per acre, but today each acre is worth $\$ 60$. It has been planted to corn and potatoes, and I invariably get better crops off the land cleared with dynamite than off other land not so cleared. I also secured a better stand on spots from which the stumps have been blasted than from other portions. In fact, I feel that the use of Red Cross Dynamite has enabled me to blast and burn the stumps cheaper than I could remove the same stumps after they were pulled. Red Cross Dynamite will be used exclusively on the 200 acres that I am going to clear next year.

I have a neighbor who had a "Smith" grubber. Last summer he worked in a twelve-acre field six weeks with two men and one team. They cleared about nine acres and the stumps are still on the edge of the field. About the same time, in an adjoining field. 1 blasted and burned every stump on fifteen acres in seven weeks, and did it alone.

C. E. SAUNDERS, Bergville, Minn. 


\section{Red Cross Cleared Land Increased in Value $\mathbf{4 0 0 \%}$}

During 1909 I cleared tiwelve acres of new ground of gum, hickory, white and red oak stumps, ranging from twelve to thirty-six inches in size.

On this work I used 40 per cent. Red Cross Extra Dynamite and while the very cheapest figure at which I could have cleared this land by any other method would have been from 50 cents to 75 cents per stump or $\$ 25$ per acre, Red Cross Dynamite did the work at about 20 cents per stump or $\$ 10$ per acre.

In addition to the above, the land increased in value from $\$ 25$ to $\$ 100$ per acre. It was planted to alfalfa during 1909 and produced a much better crop than the adjoining land on which no dynamite had been used. I noticed also that it grew very luxuriantly on spots from which stumps had been removed.

As fast as I would blow the stumps out, I would have them loaded on wagons and sold for $\$ 1.50$ per load. They were blown in such pieces as to make them very fine for fireplace wood, not needing any more splitting and the people in the neighborhood were very eager for them.

I regard the dynamite method a very fine way to clear land of stumps and take pleasure in stating that I was well pleased with results obtained. After deducting the amount received for the wood, it will bring the expense down to a very small item per stump and I shall certainly use Red Cross Dynamite on the other twelve-acre plot which I will clear sometime this year.

\section{H. A. BEATTIE, Starkville, Miss.}

\section{Used a Ton of Dynamite a Week}

It is only fair for me to report the success that I am having with dynamite as an agent in blowing stumps on my 100 -acre tract of woodland at Beartown, Lancaster County.

I am using a ton of dynamite a week in this work and with the capable force that I now have the results are marvelous. Great chestnut and oak stumps succumb to the dynamite as easily as lifting a match. The benefit derived from this method is incalculable as it practically loosens the earth or subsoil from stump and is making plowing very easy. I have a stump puller on this tract, but it cannot be compared with dynamite as it pulls out stumps leaving roots, and I cannot possibly clear over a quarter of an acre a week with it.

Anyone is welcome to come and see the results. I have a large picture taken showing the tract clear, which the photographer will no doubt let you have if you care to use it. work.

I thank you for the help that your company has displayed in furthering my FRANK S. BARR, Lancaster, Pa.

\section{Advantages of Mudcapping Boulders} 1911:

Extract from report of demonstration at Grand Rapids, Minn., July 18,

"This work was new to Mr.'A. J. McGuire, Superintendent of the N. E. Experimental Farm, and he was amazed to see large boulders which two and three teams could not handle broken up in pieces so small that they could be lifted into a wagon by one man. He had been in the habit of drilling holes twelve inches deep in the large rock and splitting them with 40 per cent. dynamite, which split the rocks but did not break them up small.

"The rocks were all granite and some of them presented round smooth surfaces on which to place the dynamite and others had good shoulders against which to place the dynamite. In the latter case a saving of two-third pounds of dynamite was effected on large rocks. Mr. McGuire emphatically stated that he would mudcap large rocks in future and expend his surplus energy in some other directions rather than drilling granite." 


\section{After Using Red Cross Dynamite Would Not Sell Land for $\$ 100.00$ per Acre Which Was Not Worth $\$ 5.00$ Before}

I follow agricultural blasting among the farmers of this section, and have used a great amount of dynamite in this work.

In stump blasting I have used dynamite on all kinds and all sizes of stumps in cultivated and uncultivated fields, and my experience has been that it is not only quicker and more satisfactory than any other method but it is cheaper by two-thirds.

As to boulder blasting probably the following experience may be of some interest to you:

In 1904 one of my neighbors bought a farm of about 108 acres. There was one field of about twenty-five acres that had never been cleared up, and boulders lay so thick that I have crossed the entire twenty-five acres without stepping on the ground. They ranged in sizes from one-half ton to twenty tons, and many of them weighing from five to eight tons were imbedded in the ground so that I could see nothing but the top.

I contracted with Mr. Buechner to break up all the boulders on this twentyfive acres in shape to draw. I used four boxes of 40 per cent. Extra Red Cross (low freezing) Dynamite, which, together with my labor charge, cost him $\$ 78$ to get all these boulders ready for a team.

Before I started to work on this land it was absolutely worthless, but since then I have seen sixty-two bushels of wheat to the acre grow on that field, also fifty-two bushels of oats per acre and 140 bushels of corn. Furthermore, Mr. Buechner has since refused about three times the price that this farm cost him, and it was nothing but Red Cross Dynamite that put it in shape.

\section{R. T. VAN DUSEN, Manlius, N. Y.}

It is all quite true what Mr. Van Dusen stated. The land was not worth $\$ 5$ before, but is as good now as any in the neighborhood. I would not sell it for less than $\$ 100$ per acre.

GODFREY BUECHNER, Manlius, N. Y.

\section{Breaking Boulders}

I have had excellent results in removing boulders and breaking them up with mudcaps. In Massachusetts, many boulders of granite formation, known as "hardheads" are found. They are usually round and smooth and frequently the larger portion of them is buried in the ground. They are regarded as a hard proposition by experienced blasters. If only a part of the boulder shows above the surface, I sound with a three-eighth inch steel rod five feet long with a sharp point and poker handle, to determine the size and position of the stone underground. I then place a relatively small charge of dynamite under one end or one side, the discharge of which rolls the boulder out upon the surface of the ground. It then takes a small charge of dynamite to completely shatter it. I frequently dispose of the pieces by placing them back in the hole, thus saving the expense of carting them away. There is usually room in the hole for all of the pieces and still allow for eighteen inches of top soil over them.

IVINTHROP FILLEBROWN, Bryantville, Mass.

\section{Largest Boulders Successfully Blasted}

I am sending you a photograph of a rock which weighed between six and eight tons. As shown by the picture one man could handle any piece of it after the blast. The farmer for whom this blasting was done had spent for labor from $\$ 50$ to $\$ 60$ in clearing five or six acres of small boulders. I cleared about as much for $\$ 8$ by using Red Cross Dynamite.

\section{H. NANGLE, Thorndale, Texas.}




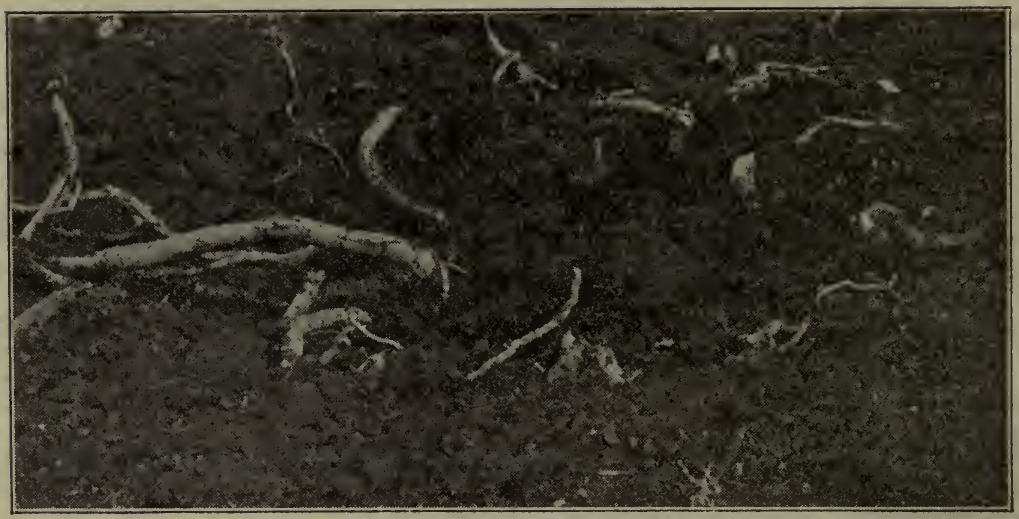

FIG. 14.-SHOWING HOW BLAST BRINGS OUT ROOTS

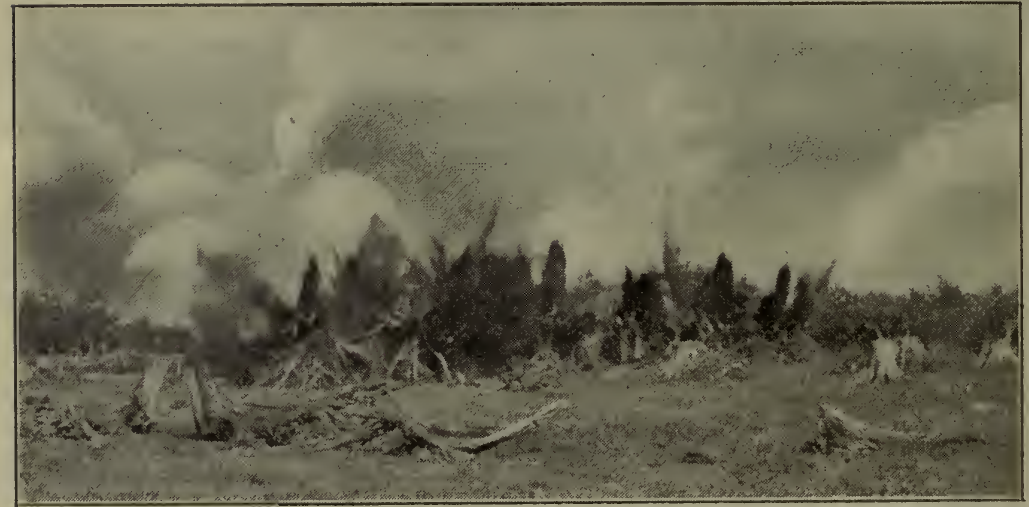

FIG. 15.-GROUP BLAST WITH BLASTING MACHINE, BARKSDALE, WIS.

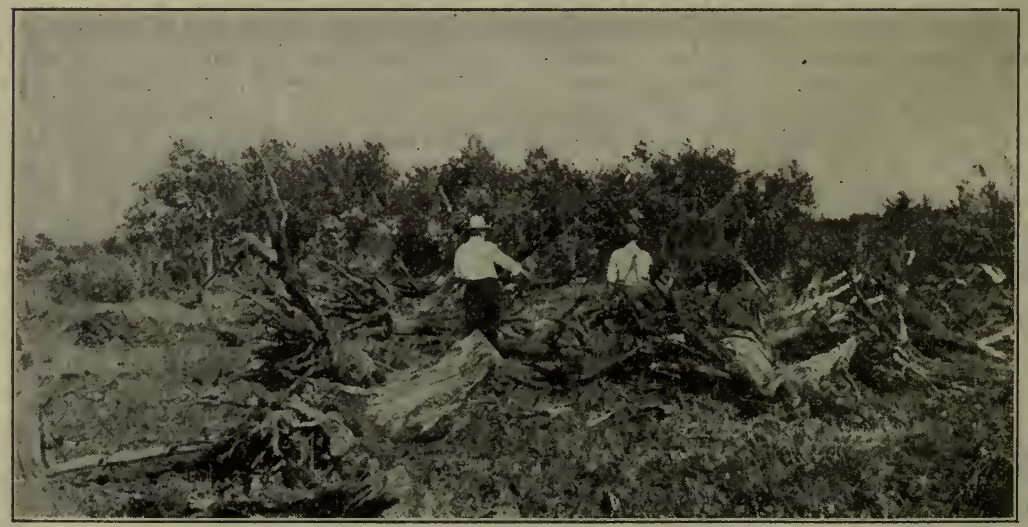

FIG. 16.-AFTER THE BLAST, BARKSDALE, WIS. 


\section{Red Cross Dynamite in the Turpentine Industry}

\section{What It Means to Owners of Cut-over Land and Turpentine Manufacturers}

The manufacture of turpentine and rosin is a very important industry in seven of our Southern States. In 1909 there were 1,585 establishments engaged in manufacturing these products. The capital invested in the business was $\$ 12$,375,000 and 41,959 officials and workmen were employed in the industry.

There were produced 555,000 casks of turpentine, valued at $\$ 17,680,000$ and $1,906,000$ barrels of rosin, valued at $\$ 18,255,000$, in the year 1910 .

Although it is a well-known fact that the stump contains a larger proportion of the material from which turpentine, rosin, tar, wood oil, creosote, etc., are obtained, than is contained in the trunk and branches of the tree, nevertheless until lately only the trunk and branches have been utilized by many manufacturers due to the excessive cost of getting the stump out of the ground and breaking it up into sizes that would go into the "hogs." Lately, however, the National Turpentine Company, of Georgia, has done some experimental work with excellent results. These experiments are of as much interest to owners of cut-over land in the vicinity of turpentine manufactories as to the turpentine manufacturers themselves.

In the course of making these experiments the National Company started using stump pullers, which required in themselves a rather heavy investment of capital, and to properly use which they were compelled to employ large crews of men and teams of horses, making the cost excessively high. Later, it was suggested to them that dynamite could do this work much more efficiently and economically. The experiment was tried and Mr. T. B. Gautier, President of the Company, made the following report:

"When measured, the stump wood amounted to seventeen cords. The total cost of explosives and labor was $\$ 50.59$, or an average of about $\$ 3.00$ per cord. These seventeen cords treated yielded eight gallons more of turpentine per cord, thirty pounds more of rosin and twenty gallons more of tar than ordinary wood. I am very much pleased with these results and expect to use dynamite for this purpose hereafter. I certify that the attached report is correct."

\section{Labor Cost}

Boring holes, 1 man $71 / 4$ days at $\$ 1.25 \ldots \ldots \ldots \ldots \ldots \ldots \ldots . . \ldots \ldots \ldots \ldots \ldots \ldots . \ldots \ldots$ Chopping roots, etc., 1 man $281 / 2$ hours at 15 cents per hour...... $4.271 / 2$ Piling and loading, 1 man $23 / 4$ days at $\$ 1.25 \ldots \ldots \ldots \ldots \ldots \ldots . \ldots . . . \ldots 33 / 4$ Piling and loading, 1 man $21 / 2$ days at $\$ 1.25 \ldots \ldots \ldots \ldots \ldots \ldots \ldots . . . \ldots 11 / 4$

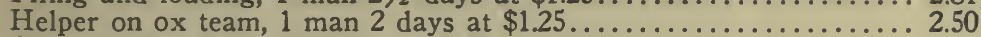

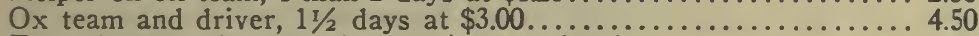
Extra help loading cars, 2 men $1 / 4$ day at $\$ 1.25 \ldots \ldots \ldots \ldots \ldots \ldots \ldots .63$

Total labor

\section{Explosives}

$3041 / 2$ cartridges dynamite ........................ \$19.87

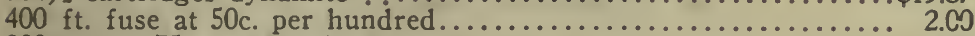

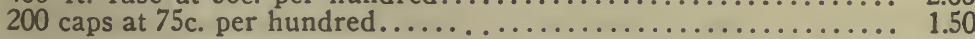

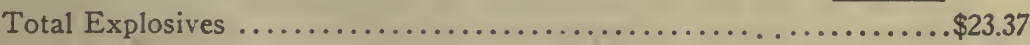

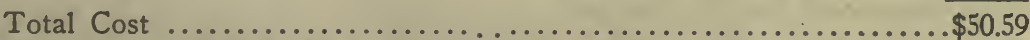

154 stumps were blasted; 17 cords produced; cost per cord........... 3.00

One cord stump wood produced 8 gallons more turpentine, 30 pounds more rosin and 20 gallons more tar than one cord of tree wood.

Value of this increase:

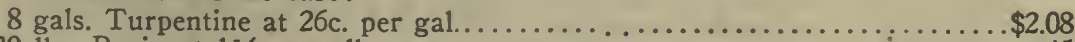

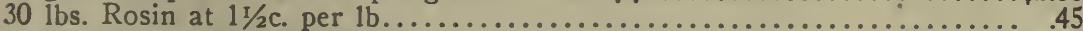

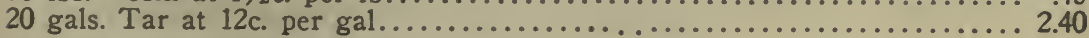


Giving a net profit of $\$ 1.93$ in favor of stump wood.

The blaster who conducted these experiments for the Turpentine Company reports that the Turpentine Manufacturers are very much pleased with the results and that land owners are now figuring on using dynamite for removing stumps from their properties and selling them to the Turpentine Company for $\$ 3.00$ per cord, because that is what the Company is willing to pay for pine stump wood.

It is an admitted fact that land which has been covered with pine forests is very rich in plant foods and will yield bounteous crops if utilized for farms or orchards. The drawback heretofore has been to get the land cleared of stumps. The lumber companies have already cut the marketable timber. Some of the cut-over lands are still the property of the lumber companies. Many thousands of acres, however, have been sold at low prices to settlers who have been laboriously clearing it by digging, grubbing and burning a little at a time as they have leisure to devote to it.

These cut-over lands can now be cleared up rapidly at no actual expense to the settlers and lumber companies for they will be able to sell the stumps to the Turpentine Companies at a price that will, at least, fully cover the cost of the dynamite and labor used in the clearing work.

Apart from the far-reaching importance which this has to the agricultural development of these seven Southern States, it is of greater magnitude to the poor settler, who will now be able to clear his lands and get them into shape for the production of large and profitable crops. Lumber companies still owning cut-over pine lands can now clear them and sell them as cleared land for at least double the price they can secure for them as stump encumbered land. In short, by clearing the land, they double its value at no expense to themselves, because the cost of the clearing is more than paid for by the money received for turpentine from the stump.

\section{Value of Products Obtained From Dynamited Pine Stumps Exceeds Value Obtained From Tree Wood}

We obtained nine cords of wood from seventy-five stumps at a total cost of approximately $\$ 3.10$ per cord delivered at our plant. This included a haul of about half a mile.

The value of the product obtained from this wood exceeded the value obtained from the tree wood. We have a crew at work shooting stumps now and expect to start another crew next week. From present appearances we will use larger quantities of Red Cross Dynamite in the near future.

ATLANTIC TURPENTINE \& REFINING CO., E. B. Smith, Gen. Supt., Savannah, Ga.

\section{Pine Stumps Blasted Out, Split and Ready for the "Hogs" at $\$ 2.66$ per Cord}

As to the cost of producing stump wood for our plant with dynamite.

The cost of the first sixteen cords was approximately $\$ 2.66$ per cord for shooting out the stumps, chopping them to suitable size for our purpose and piling them ready for the wagons.

We have gotten out several car loads of stump wood at prices varying from $\$ 2.61$ to $\$ 2.98$ per cord.

We have recently made our first run of stump wood with very satisfactory results.

Today we are ordering our second shipment of explosives and expect to use sarge quantities of dynamite in the future.

STANDARD TURPENTINE COMPANY, Per Frank L. Fogarty, Acting Assistant Treasurer. 
The foregoing clearly proves the advantages of clearing land with dynamite instead of by any other means, and the following is a condensed outline of the benefits derived by doing this work.

The stump-covered site of a former piece of woods is, as you know, new, rich soil that needs no fertilizer.

You also know that pulling stumps with a machine is the hardest kind of work-liable to seriously injure yourself or your horses, and certain to require a lot of work to get rid of the stump after pulling.

Then, too, it leaves the field full of holes, that must be filled; and plowing the hard, packed soil around old roots is no joke.

If instead of pulling the stumps you burn them out, the intense heat required destroys the humus in the soil all around the fire and you will have a burned field requiring a good deal of cultivating instead of new fertile soil.

You can dynamite all those stumps for about one-third the cost of pulling and chopping them up.

The blast splits up the stump into firewood, removes all the dirt, breaks all the main roots, and loosens the soil for yards around.

You can blast fifty stumps in the time it would take to pull and chop up one or two.

One man can do all the work, if necessary.

After the stumps are all blasted out, you will have a new, rich field, easy to cultivate, and which will yield bumper crops.

If you want to remove a whole tree, Red Cross Dynamite will lift it bodily out of the ground, and it will usually fall with the wind. When this is done, there is no stump to remove.

The split stumps can be removed easily to one place, burned, and the ashes saved for spreading on the land or for leaching.

If whole stumps are preferred for making fences, they may be blown out whole by regulating the charges.

Boulders, which you are now obliged to plow around, can be broken up into easily-handled blocks by a single blast.

Red Cross Dynamite not only removes your stumps and boulders but at the same time subsoils your land. The action of the explosion is such as to loosen and shake up the subsoil for a considerable distance around, the blast thereby rendering the land porous and mellow. It is an easy matter to pick out, after crops are grown, the various places where stumps have been blasted because of the great difference in yield as compared with the rest of the field.

All of the foregoing claims are conclusively proven by the letters of disinterested parties, who have tried our methods, which are quoted in this booklet. Follow their advice; take advantage of their experience; join the Red Cross Army and be the happy, prosperous owner of a productive, sightly farm. 


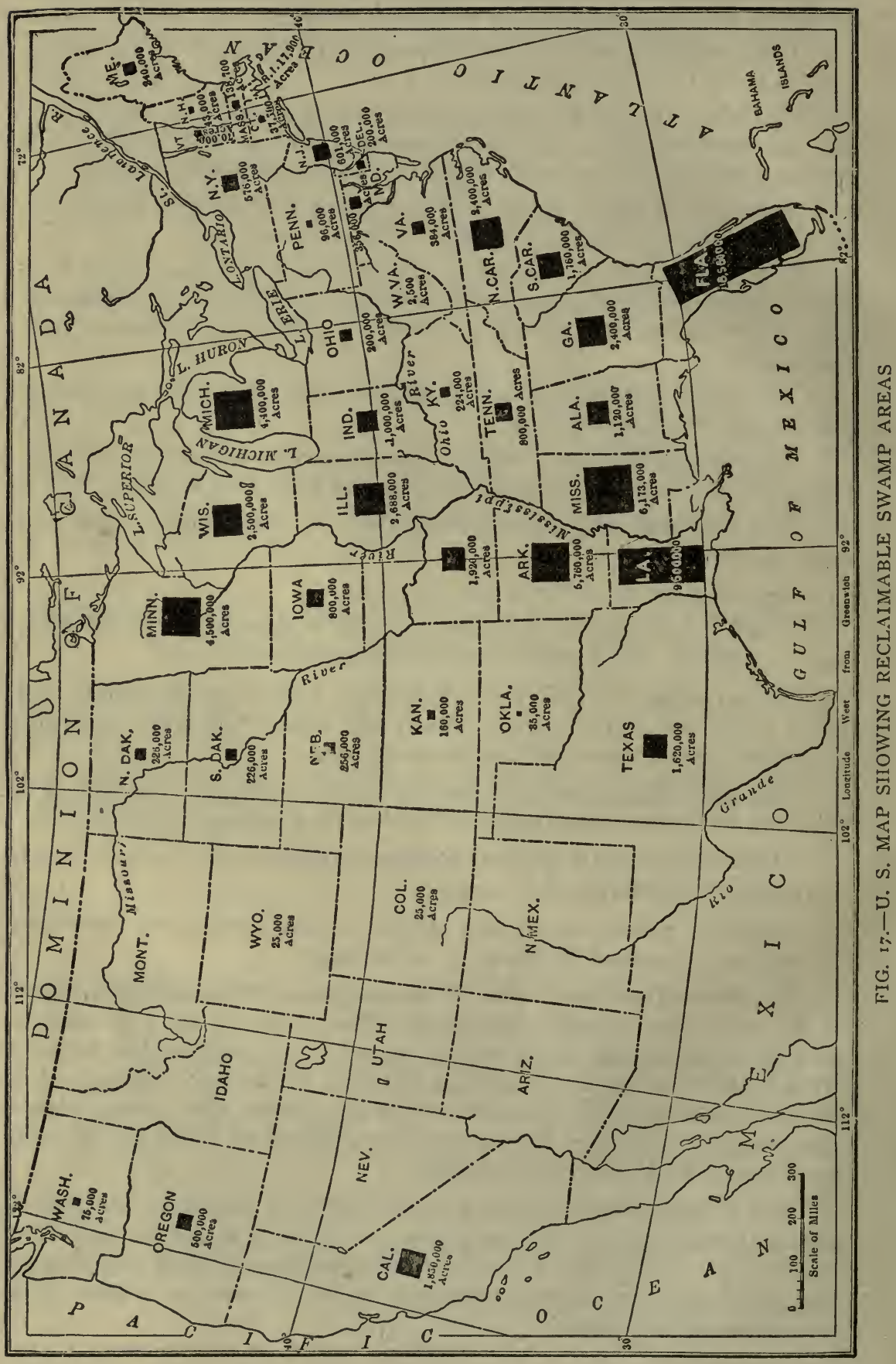




\section{I T C H I N G AND \\ DRA I NA GE}

W I T H

\section{RED CROSS \\ DYNAMITE}

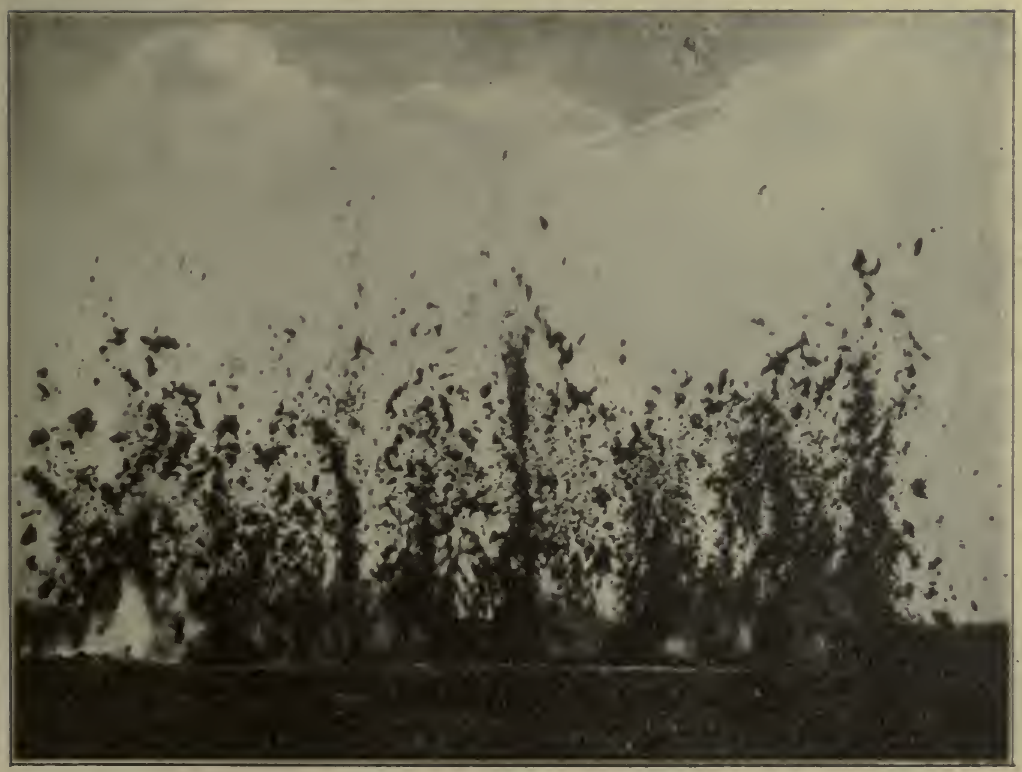

FIG. 18.-110 FOOT DITCH BLAST, ELK GROVE, SACRAMENTO CO., CALIF. 


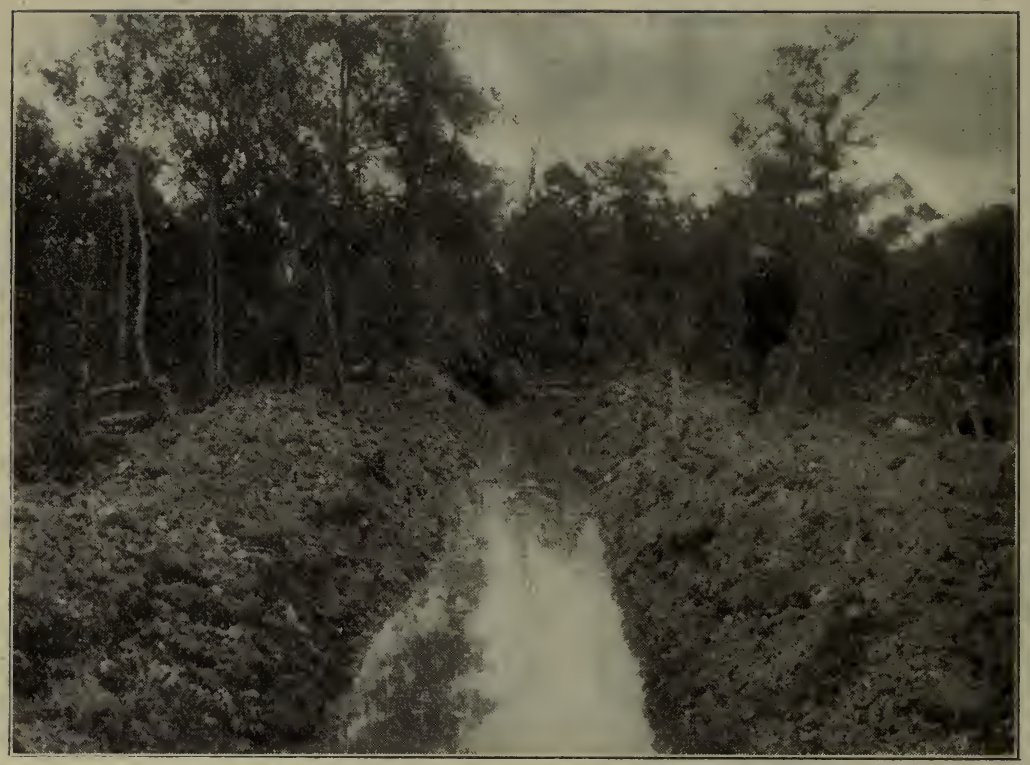

FIG. 19.-GOVERNMENT EXPERIMENT IN BLASTING DITCHES, CHARLESTON, S. C.

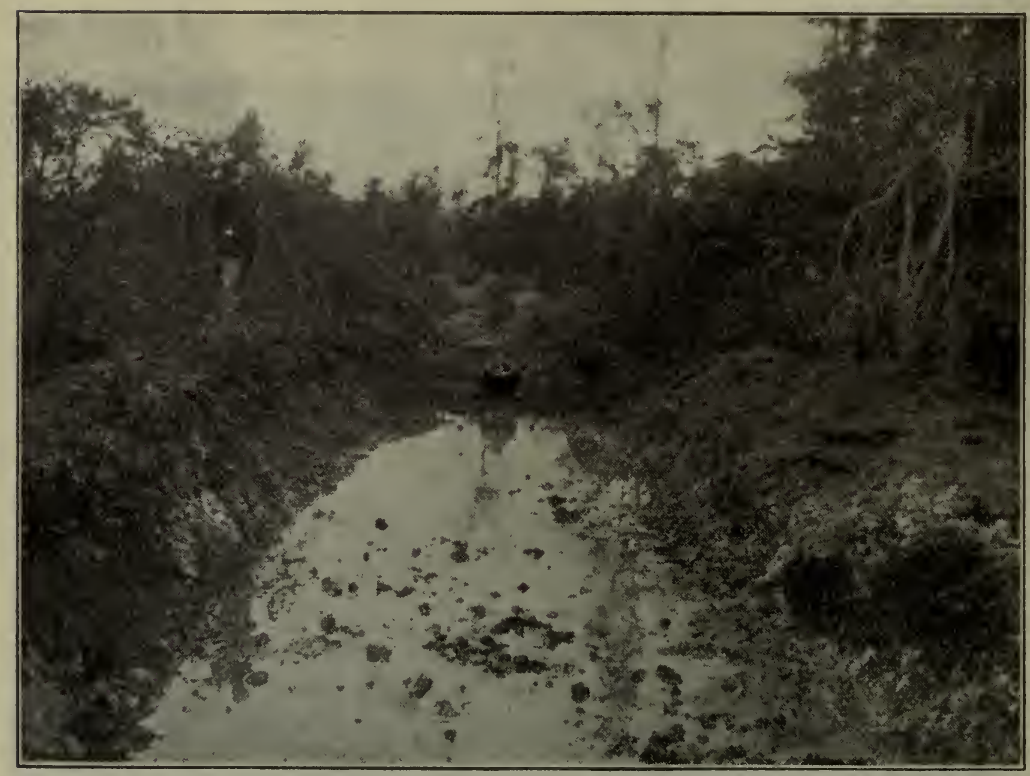

FIG. 20.-ANOTHER DITCH. SAME EXPERIMENT 


\section{Reclamation by Drainage}

The First National Drainage Congress met in Chicago December 9, 1911. Among the facts presented were the following:

That there are in the United States more than 75,000,000 acres of swamp land that are non-productive.

That the drainage of this land will reclaim it for agricultural pursuits and add several billions of dollars to the wealth of the nation.

The location of these reclaimable swamp lands and their approximate areas are shown in the table below:

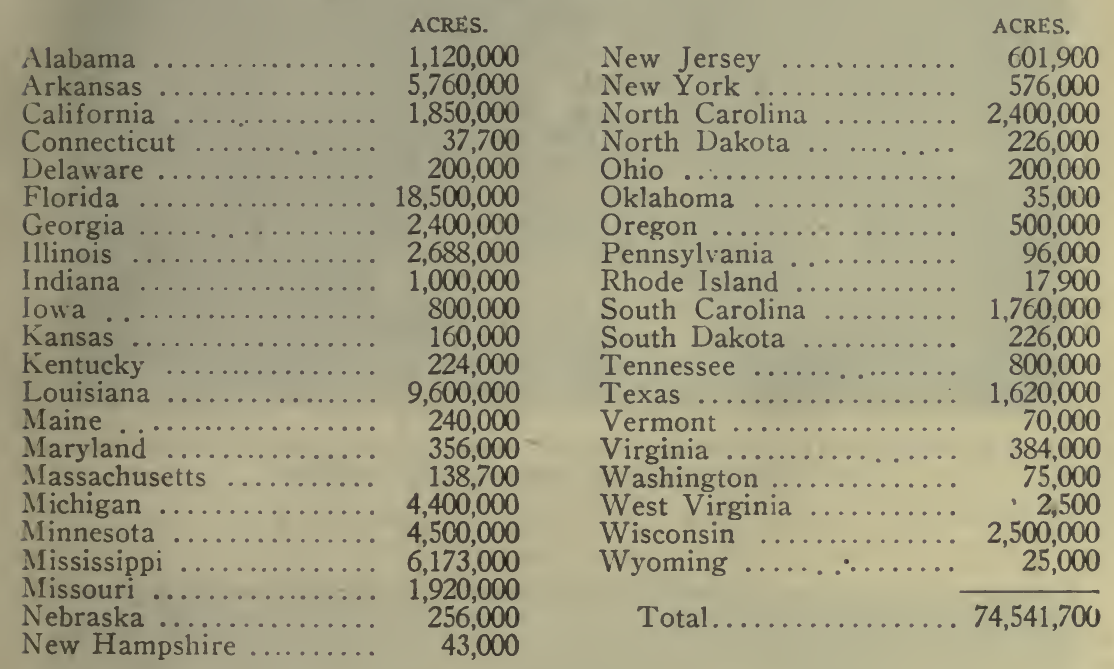

A writer in a Southern publication gives the following interesting information regarding the swamp areas of the United States and the value of these areas if they were drained.

"The latent wealth in $10,000,000$ acres of reclaimable delta and overflow lands of Louisiana is so much greater than any discovery of mineral wealth in gold deposits that was ever made that it is hard to make a comparison. If that land were reclaimed, settled and cultivated, with a settler and his family on every ten-acre farm, it would yield every year food products that could be sold for gold aggregating a thousand million dollars a year. And if it were known that along the marshes of your coasts and under the waters of your bayous there was $\$ 1,000,000,000$ contained in gold deposits of some form, you would have a gold rush from every part of the world that would bring greater multitudes to your state than the gold discovery of 1849 took to California.

"There is no place in this world where such latent possibilities of agricultural wealth exist on such a stupendous scale as in Louisiana.

"This whole question of land reclamation or drainage is of enormous importance nationally. There are estimated to be $74,541,700$ acres that can be reclaimed by drainage and it is scattered through forty states." 


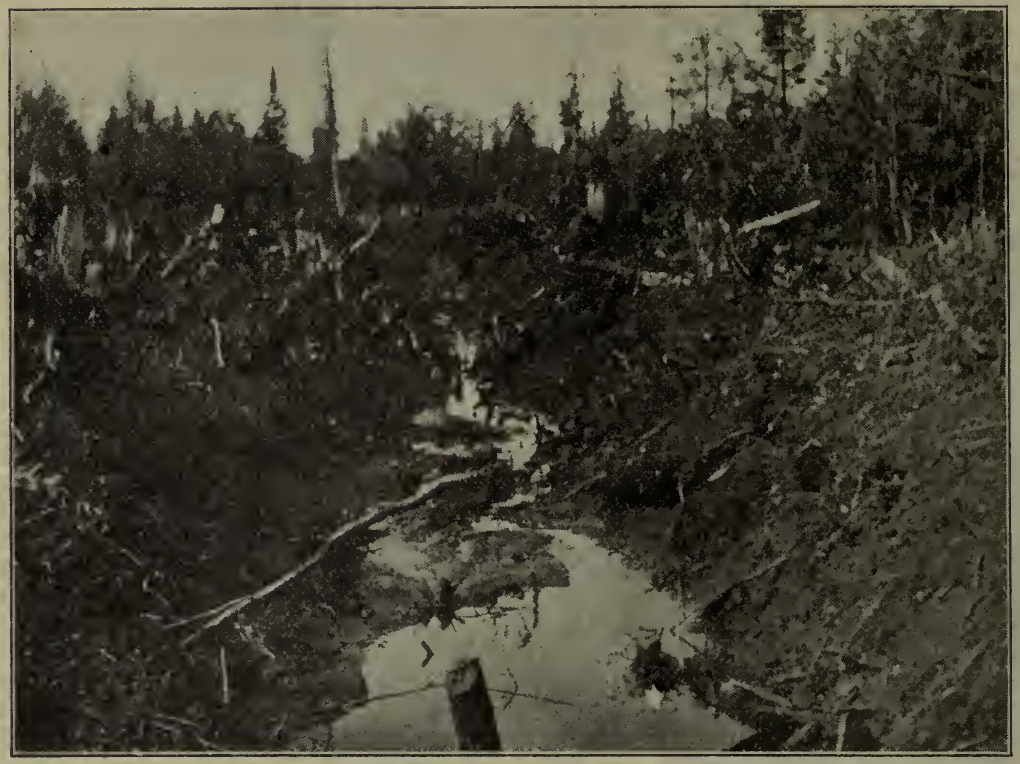

FIG. 21.-DYNAMITING DIGS DITCHES THROUGH LAND THAT CANNOT BE ECONOMICALLY HANDLED OTHERWISE c

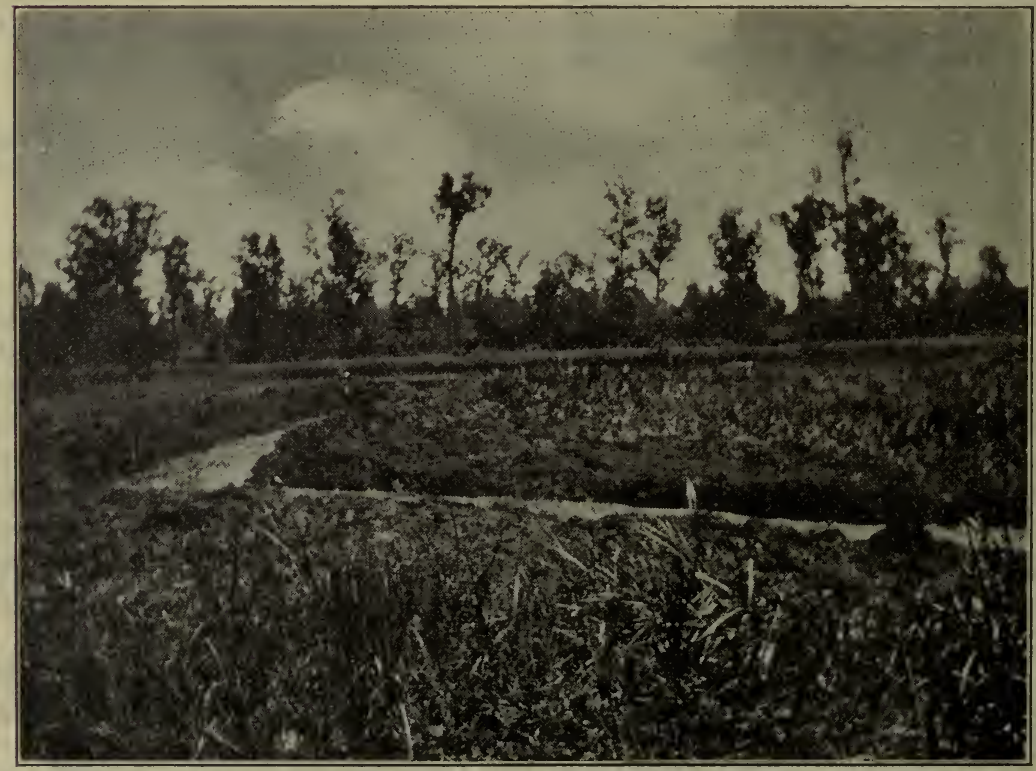

FIG. 22.-A DITCH BLASTED AROUND A CORNER IN ONE BLAST 
Col. Will L. Sargent, traveling immigration agent of the joint Texas and Louisiana Immigration Bureau, is another enthusiastic believer in reclamation by the drainage process and has spent a great deal of his time studying land conditions, soil possibilities, the results of reclamation, the crops that are produced after the land has been reclaimed and every other phase of the subject.

"The reclamation, by drainage, of our. wet lands will produce better health," declared Col. Sargent, "and if the 74,000,000 acres in the United States were reclaimed and divided into 40-acre farms there would be added 1,850,000 new farms. And if each farmer spent $\$ 350$ per annum the purchasing power of this class of farmers alone would mean $\$ 647,500,000$ that would go into the various channels of trade, etc."

Continuing further along that line, Col. Sargent said: "Estimating five persons to the family for each of the 40-acre farms, the agricultural population of the United States would be increased 5,550,000. Under intense cultivation these lands could be made to produce, at a most conservative estimate, $\$ 50$ per acre, or $\$ 3,700,000,000$, as an additional production of wealth which would be distributed throughout the country.

"The federal government places the cost for draining at from $\$ 2$ to $\$ 30$ per acre. Let us place the average cost at $\$ 25$ per acre. and you will find that the total cost for reclaiming the $74,000,000$ acres would amount to $\$ 1,850,000,000$. Any drained project, if served by transportation, judiciously managed, will yield a much larger profit as an investment than almost any other line that is conservative that one can engage in. Besides, it is a safe investment.

"The cost of drainage, as compared with other work of improvement, is small," continued Col. Sargent. "The average cost of the reclaiming of arid and semi-arid lands for irrigation in the western part of the United States, which is done by the federal government under the Cary Act, is about $\$ 36$ per acre, some projects costing as high as $\$ 100$ per acre. It is a safe conclusion to say that a person can acquire at least two acres of drained land for the cost of one of irrigated lands. Besides the greater portion of the lands subject to drainage already have, or there are nearby, transportation facilities as well as settlement, which is seldom the case with irrigated projects.

"If these rich lands were drained and placed upon the market, we would not only stop the great tide of emigration from the United States to Canada, but in turn could secure many Canadians that are well-to-do, and who have become tired of that frigid climate and desire to migrate where they do not have to house their stock and themselves nine months in the year to keep from freezing, thereby consuming the most of their products made during the short-crop season."

In order to present the magnitude of the swamp areas of this country, it is simply necessary for us to state that it equals about onesixth of the entire cultivated areas of the country.

These swamp lands are exceedingly rich in humus and valuable plant foods. When drained and prepared for cultivation, they will produce larger crops than any other existing soils. 


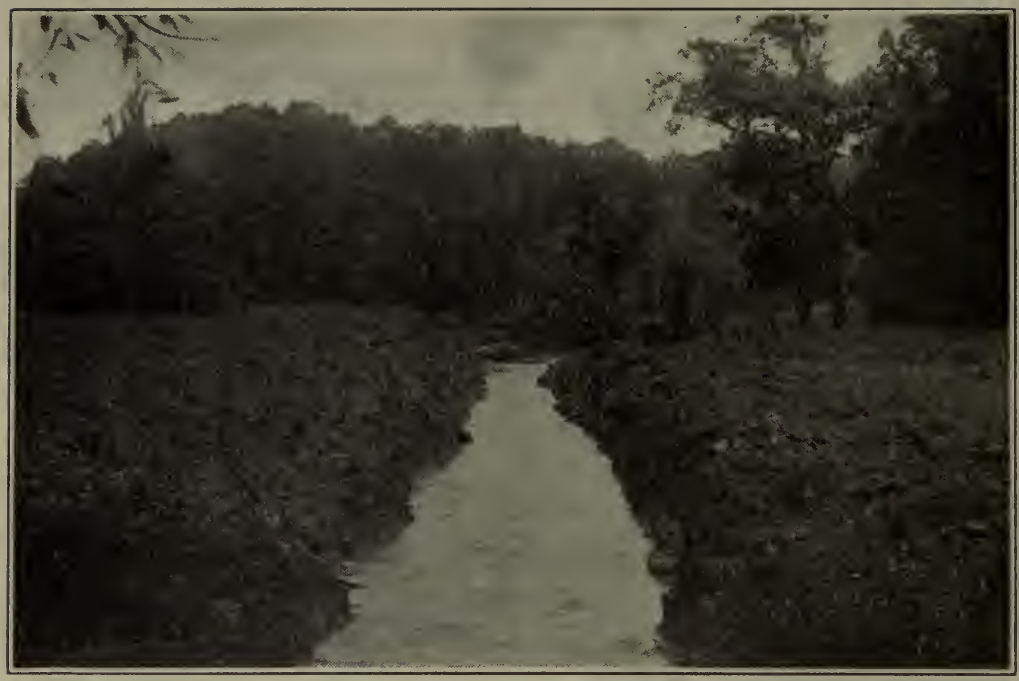

FIG. 23.-DITCH BLASTED AT WESTCHESTER, PA., TO CHANGE COURSE OF STREAM

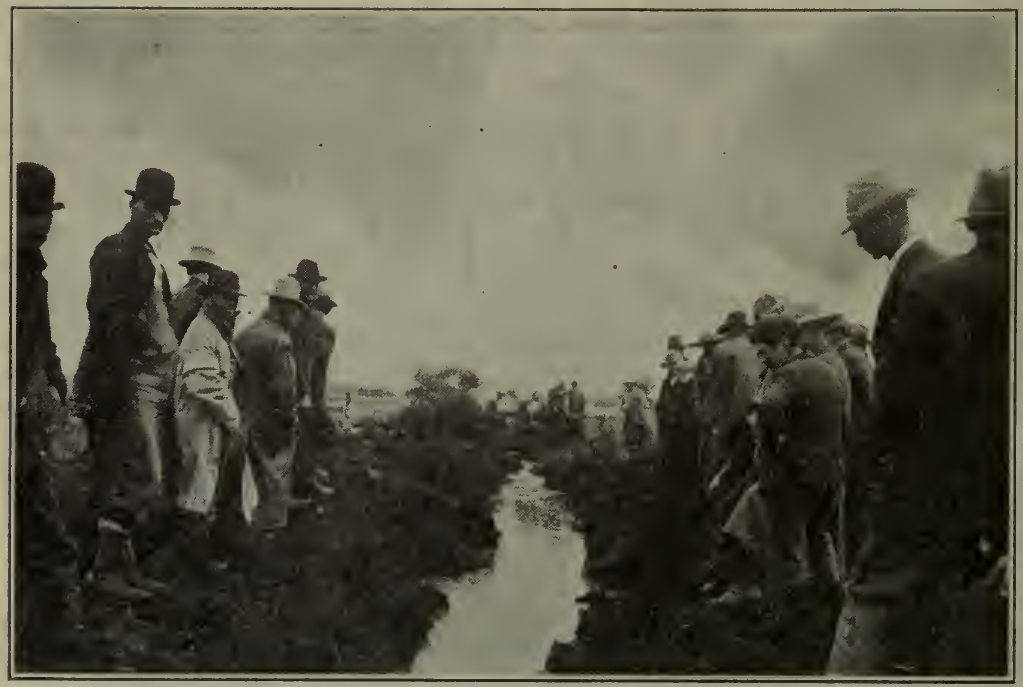

FIG. 24.-DITCH BLASTED IN HEAVY SOIL AT ALBANY, ORE. 


\section{[. Advantages of Red Cross Dynamite for Ditching}

Farmers have been using Red Cross Dynamite for draining swamps and wet fields for many years, and much valuable farm land has been reclaimed and made available for cropping by so doing. The cost of the work and of the explosives is very small compared with the value of the land reclaimed.

The draining is accomplished in one of two ways, depending upon conditions. Sometimes it is better to drain wet land by ditching, while at other times it is more practicable to permit the water to escape by a process of seepage through the soil.

It is not always possible to drain by ditching. Whether it can be done in that way depends upon whether the slope of the land permits. If the swampy or wet spot is low, surrounded on all sides by hills, ditching would not work. The drainage can then best be done by subsoil blasting. This is done by exploding charges of dynamite sunk deep in the ground, which breaks up the hard soil and allows the water to find an outlet through the sand and gravel beneath. Whether this is practicable, of course, depends upon the thickness of the stratum of impervious subsoil and also upon its depth beneath the surface soil.

For ditching, blasting is superior to old time pick and shovel methods in every way. One of the most difficult problems the modern farmer has to face is the securing of farm labor. Therefore, any method of doing farm work which makes possible the employment of fewer men is recognized as a good thing. To dig a big ditch quickly by manual labor requires the employment of a number of men for a considerable period of time. Where are the men to be had? Using dynamite for ditching solves the farmer's problem. One man equipped with a pointed steel bar, a sledge hammer and a supply of dynamite cartridges, fuse and blasting caps, or electric blasting machine, can excavate as much ditch in one day as many men could dig out with picks and shovels.

Blasting a ditch is a very simple matter. After making the holes the proper depth with the pointed bar or punch, the blaster places the dynamite cartridges at the bottom of the holes, and then explodes the charges. The dynamite does all the work. If soil conditions are favorable, the result is a nice, clean ditch of the required depth and width, the earth being spread evenly over the ground along the banks. and turning in the water clears away what little of the dirt may have fallen back into the trench after the blast. The cost of ditching with dynamite runs from 8c. to 12c. per cubic yard, compared with an average cost of $25 \mathrm{c}$. per cubic yard when the work is done with pick and shovel.

Dynamite is not recommended for excavating large ditches having a depth greater than 6 feet, or width greater than 16 feet, but within these limits it is the quickest and usually the cheapest means for ditching.

In large reclamation projects the main canals can usually be excavated cheaper by dredging machines, but for laterals and sub-laterals Red Cross Extra Dynamite is better. 


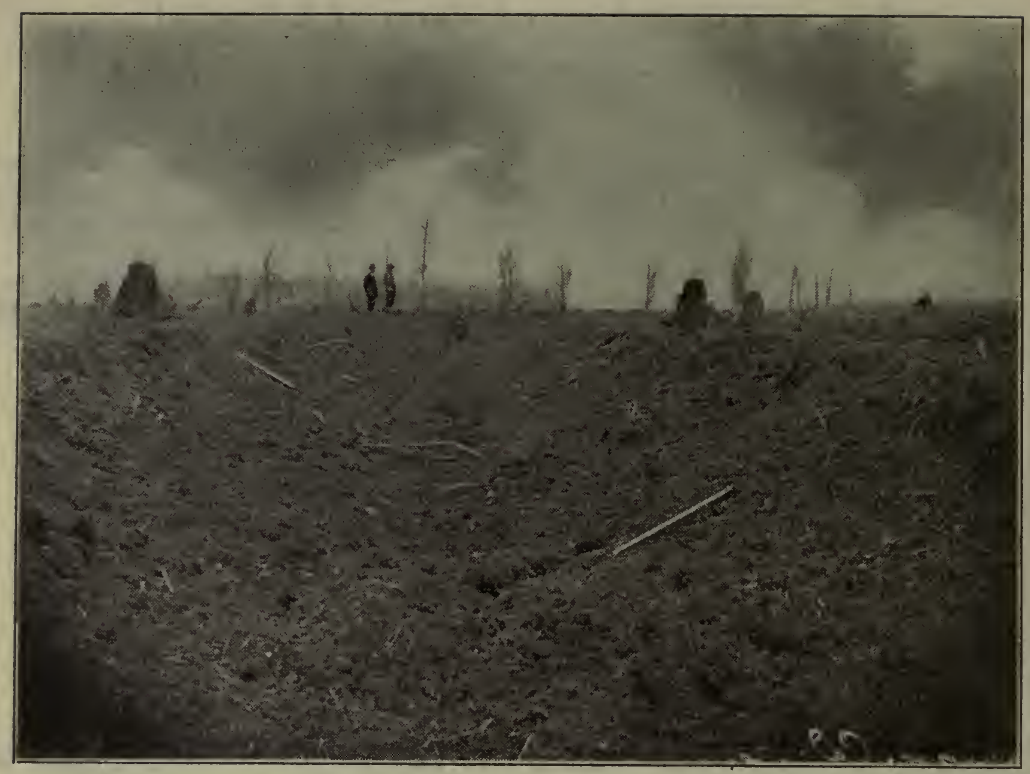

FIG. 28.-AFTER A BIG DITCH BLAST AT DIEHLSTADT, MO.

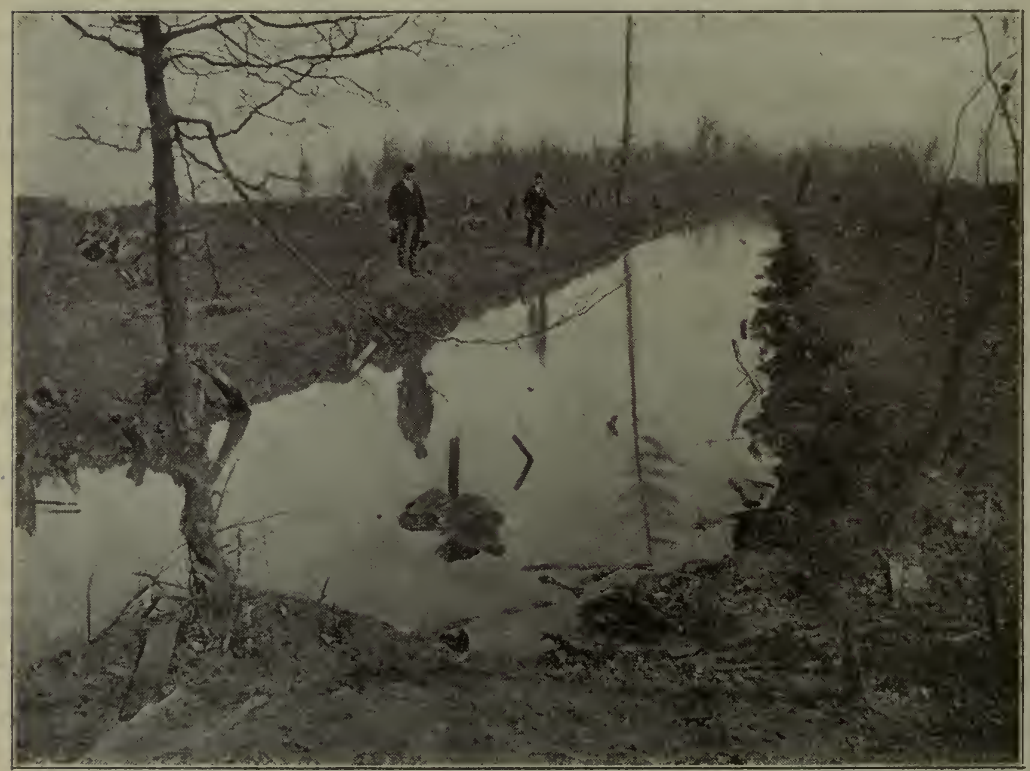

FIG. 29.-SAME DITCH AS IN UPPER VIEW, FILLED 


\section{Land Value Increased $\$ 130.00$ per Acre}

IVhiteside, Kansas, February 21, 1912.

In reference to the wet land shot for me by Mr. A. G. Crabb:

There never has been any water stand on this land since shooting. It cost me about fifteen dollars $(\$ 15.00)$, and I have had as good oats on it as on any of the field. This year it is in wheat, and the wheat looks better where the pond stood than on the rest of the field.

Before shooting this land was worthless, but I have since refused $\$ 130.00$ per acre.

GEORGE IV. SIEGRIST,

Hutchinson, Kansas.

\section{Du Pont Dynamite Saves $\$ 435.00$ for This Missouri Farmer and Increased Value of His Farm by Increased Crops}

On March 10th, 1911, a large ditch was shot at Diehlstadt, Mo., on the farm of Mr. Max L. Ostner. See opposite page, showing finished ditch and water flowing through it.

The length of the ditch made was 1,720 feet. Three rows of holes, 3 feet apart each way, were drilled, the rows being staggered. The center row of holes were 3 feet 8 inches deep and the two outside rows 3 feet deep. In each of the centre holes were loaded 3 cartridges, Hercules $50 \%, 11 / 4 \times 8$, and in each of the outside holes 2 cartridges. It was originally planned to fire the entire 1,720 feet of ditch with one set of primer holes, i. e., two holes in each row, these holes being loaded with an extra cartridge, containing the cap and fuse. When fired 500 feet of the ditch was cleaned out, and it developed that there was a dry sand ridge in the centre of the 1,720 feet which extended about 400 feet, this preventing the entire 1,720 feet from being excavated with the one priming. A second primer group was arranged and in this shot 800 feet of ditch was made. Several extra primings were necessary to get the dry sand ridge blown out cleanly. There was about 1 foot of water in all the holes blasted with the exception of those in the dry sand ridge. The soil in the remainder of the ditch was a sandy loam with some mixture of clay.

The ditch made was 16 feet wide at the top, 8 feet wide at the bottom and averaged 4 feet in depth. It was fairly well cleaned out all along.

The total cost of the ditch was $\$ 329.00$. There was moved 3,058 cubic yards of material, costing $10.76 \mathrm{c}$. per cubic yard for the entire work, against $25 \mathrm{c}$. per cubic yard if the ditch had been dug by pick and shovel.

The temperature at the time of demonstration was 62 degrees $F$., in the sun, and 49 degrees in the shade. The temperature of the water in the holes was 35 degrees Fahrenheit.

\section{Dynamite Cuts Cost in Two}

\section{Onamia, Minn., Aug. 9, 1911.}

In regard to ditching with dynamite will say, it's grand in wet ground. The ditch dug on my place would cost me at least $80 \mathrm{c}$. per rod, and with dynamite it was less than half; and then such quick work. One minute after loading was done the water came running in like the ditch had been there all the time. I think it was fine. 


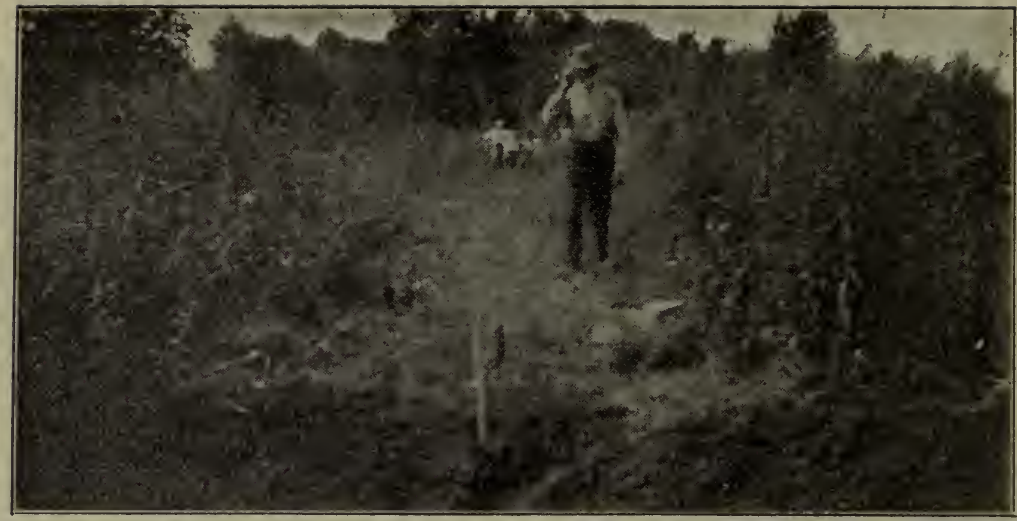

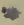

FIG. 25.-BEFORE THE BLAST, BURKETT FARM, NEWBURGH, N. Y.

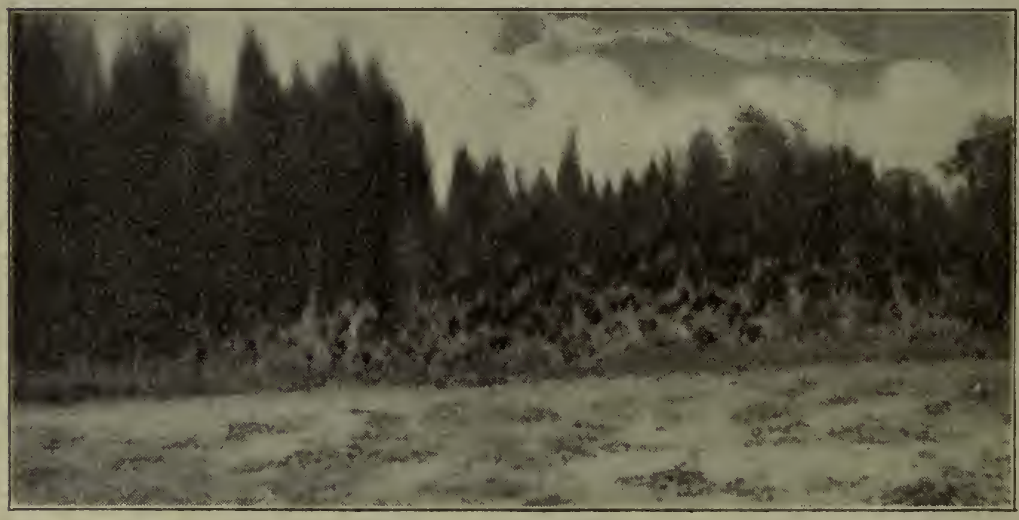

FIG. 26.-THE BLAST

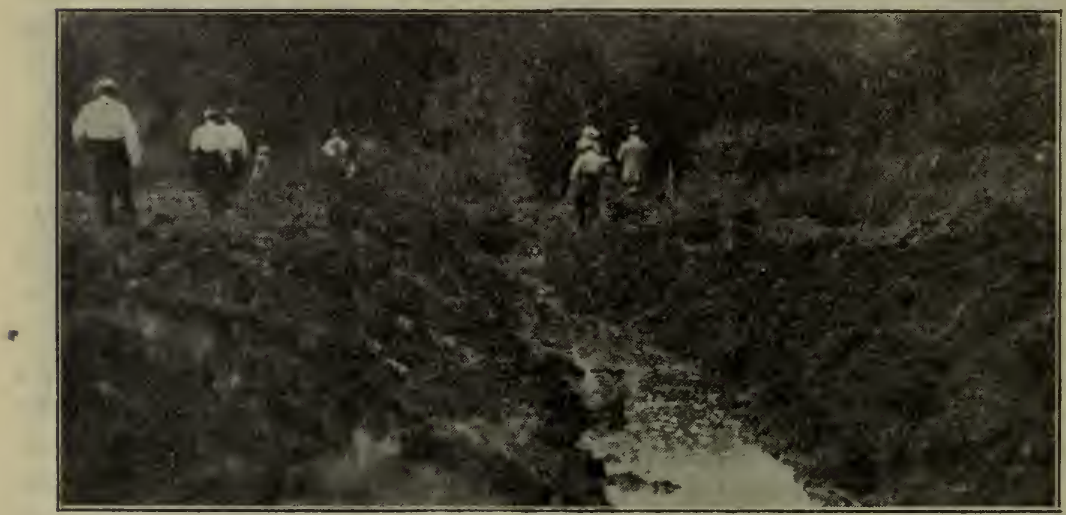

FIG. 27.-A FEW MINUTES AFTER THE BLAST 


\section{Successful Ditching on Farm of Editor of}

\section{American Agriculturist}

Newburgh, N. Y., JuLy 18, 1911.

"The dynamite demonstration on my farm last week was an emphatic success. The ditching was a complete surprise to everybody. The dynamite certainly did the work and made as pretty a ditch as ever I saw. (See 1 ts on page 32 .)

"The subsoiling work I am confident is full of promise. I shall follow all these matters very carefully from year to year and record just what results have been obtained.

"C. N. BURKETT."

\section{A Professional Blaster's Report of Some Drainage Blasts}

HUtChinson, Kan., JANUARY 16, 1912.

E. I. du Pont de Nemours Powder Co.

Wilmington, DeL.

Gentlemen:

Received your letter, have read it over carefully and would say that the Severance Farm, where I dynamited has raised in value fifty dollars per acre and also that the Wells Place three miles south of Hutchinson where I dynamited to drain ground, was just in small patches, but he got enough wheat off the blasted ground to pay for shooting his whole eighty acres.

As for Mr. Spankenberg $r$ he had a big basin in the middle of his field. I went out there last Februa $y$ and shot fifty pounds of Du Pont $40 \%$ Red Cross on this five acres and in one week from the day I shot this we had six inches of rainfall (in one week) and Mr. Spankenberger rode out to his field expecting to find a pond as usual, but to his surprise his ground was dry, no water standing in this basin. This was a poor corn year in this country, but Mr. Spankenberger raised corn enough on this basin to more than pay for shooting this land.

Mr. Jake Siegrist, four miles southwest of Hutchinson, had a piece of land similar to Mr. Spankenberger's and I shot fifty pounds of dynamite on it and he raised a corn crop on it this year. Also Mr. George Siegrist at Whiteside. Kan.. had a piece of land on his place of five acres that was worthless. I shot thirty pounds of dvnamite on this ground one year ago and today this ground is worth seventy dollars per acre.

I went up into Pawnee County two years ago and shot a piece of ground that was under water two feet deep at the time, consisting of thirty acres. I drained the water all off that ground with twenty-five pounds of dynamite and Mr. Ford plowed this up and sowed it to alfalfa and he has got as nice a field of alfalfa now as there is in Pawnee County.

I also dynamited thirtv tree holes for Mr. Friends in Rozel. Kans., and he did not lose a tree. I also dynamited thirty tree holes for Mr. Smith and every tree he planted lived but one. I dynamited thirty-one tree holes for Mr. Yaggar of Rozel. Kans., and his trees all lived, and trees don't grow in this country in an ordinary tree hole.

All of those places I have told you about I have kept personal track of and I know what they were and what they are now, besides dozens of others.

Yours truly,

A. G. CRABB,

720 E. 7th Street, Hutchinson, Kans. 


\title{
Ten Days' Work in One Day
}

Relative to the demonstration of ditching work given by your company on May 16th, at Vandalia, I would advise that the result of this demonstration was highly satisfactory to all interested.

The ditch averaged 4 feet deep and 6 feet wide at the top. Owing to the fact that the work was done in dry ground it was necessary to use a battery in connection with same. This increased the cost of the work. In the manner in which the ditch was shot, t1. expense averaged $\$ 1.30$ per rod, Had the ground been wet the cost would have been $90 \mathrm{c}$. per rod. To have done the work with teams and scrapers would have cost us $\$ 1.50$ per rod and required 10 days to complete the work that was done in one day.

Yours truly,

GEO. F. SNERLY,

District Drainage Commissioner, Fayette County, Ill.

\section{Does Four Days' Work in Three Hours}

London Grove, PA., November 6, 1911.

I am pleased to advise that I have used Red Cross Dynamite for draining swamps on my property, reclaiming about one-eighth of an acre, which has always been unproductive. This is now pasture land.

This land was arained by ditching, and I found the use of dynamite for this work less than one-third the cost of digging by hand and then hauling away the dirt. The time consumed in ditching with dynamite required about three hours for one man, and by the old method of digging it would have taken one man at least four days. This would have left dirt on the ridge along the drain, whereas by using dynamite it was distributed evenly along the sides.

T. S. GROFF.

\section{Uses Dynamite in Irrigation Ditching}

\author{
Billings, Montana, Feb. 17, 1912.
}

Last spring (1911), your Mr. J. C. Horgan made four shots on my place. The idea was to loosen up the gravel and hardpan so that the water would drain from the low ground into the drain ditch which traverses my property.

Hitherto, during the irrigating season, water would stand on low areas of my ground, and it would be necessary for me to run lateral drain ditches from the main ditch to the low spots. Mr. Horgan put holes down about five feet and charged them with one and one-half pounds of Dupont Red Cross dynamite.

This summer the ground thus shot absolutely drained into the main drain and water would not stand on it, so 1 can recommend this system to any wishing to overcome similar conditions.

Yours truly, BILLINGS GREENHOUSE CO., By J. W. Partington.

\section{Endorsed by Experiment Station}

We have done some remarkably efficient ditching work at a small cost (compared to teams and pick and shovel) by using dynamite. I have in mind a piece of ditch 50 feet long, 6 feet wide, and 3 feet deep, which was dug at a cost of $123 / 4$ cents per cubic yard. An argument that greatly favors using dynamite in this particular kind of work is that no water holding banks are thrown up, resulting in almost perfect surface drainage. Another feature greatly in favor of using dynamite in ditching is the rapidity in which it can be done. When the ground is wet and heavy, and farming operations are at an enforced standstill, then is the time to do the best work in ditching-with dynamite.

. PAUL D. PERKINS, Supt. Angleton Station, Texas Agricultural Experiment Stations. 


\title{
8000 Acres Reclaimed by Ditching
}

Hernando, Miss., Jan. 15, 1912.

Your letter received this A. M. in regard to the use of explosives. I have had a very remarkable success in this line, especially in blasting stumps, ditches and hardpan.

There was a large drainage district in this county, called Hurricane Swamp Land District, comprising about eight thousand $(8,000)$ acres of land not susceptible to cultivation. Bonds were issued to the amount of $\$ 10,000^{\circ}$ for a ditch 8 feet wide and from $2 \frac{1}{2}$ to 10 feet deep. My father was interested in several thousand acres of land in this district, so he bought the bonds and carried out the contract of excavating the canal.

I was put in charge of the above work and completed the canal, using over two thousand $(\$ 2,000)$ dollars worth of Red Cross Dynamite bought from Levi Joy \& Company, of Memphis, Tenn. I started this work, removing the stumps with a stump puller, but found I had struck a hard proposition. My first order for one thousand $(1,000)$ pounds of $40 \%$ dynamite made the stumps come so easy that I thought blasting the ditch was possible, so I began and in a few days could remove more dirt for $\$ 1.50$ invested in dynamite than $\$ 3.00$ of shovel work. I made average of handling dirt at $111 / 2 \mathrm{c}$. per cubic yard where it would have cost me 20c. to shovel same. Where the cut was more than $6 \mathrm{ft}$. negroes would not attempt to use the shovel but wanted barrows. So here is where Mr. Negro lost out, as the dynamite blew it out most successfully.

The above canal was in made land from 4 to 10 feet deep and required considerable boring to get under some of the largest stumps, but after the explosion I had no bother with pulling the remains off right of way. In using the stump puller it was more trouble to remove the stumps after being pulled as the dirt remaining on some of the stumps would weigh tons and had to be loosened and knocked off with the use of two (2) sticks of dynamite. When using dynamite a man could roll it off with little trouble right away, and without the dynamite he could have hardly pulled it off with eight yoke of cattle.

This land that was worthless is now the finest land in the county. I have used the $40 \%$ dynamite in all of my work and we attribute the fast coming and washing due to the use of your explosives. I hope to dynamite about 15 acres of my own farm between now and the 15th of March. The above work will be subsoiling as we have a very heavy clay subsoil in this district. I thoroughly understand setting trees with dynamite and all its branches.

Yours very truly,

N. C. BANKS,

Box 14, Hernando, Miss.

\section{Straightens Creek With Dynamite}

\author{
YALMAR, Mich., Sedt. 21, 1911.
}

The ditching proposition hit me the most and would never believe until I saw your men do it here, as the creek was making all kinds of turns and swings and cutting my farm up in an awful shape, and I could have had it done long before this if I had only known how, and with a great deal less labor and at half cost than to do it with a team and scraper. Even then it would have been very hard to get it done on account of all the roots and big stones there are in places which were easily shot out with dynamite.

The ditch they shot here to my measure was 80 feet long and 7 feet wide and $31 / 2$ at bottom, $31 / 2$ feet to 4 deep with the cost of $\$ 2.25$, which would cost me close to $\$ 1.25$ per rod if I was to have it done with team and scraper or with a shovel. 


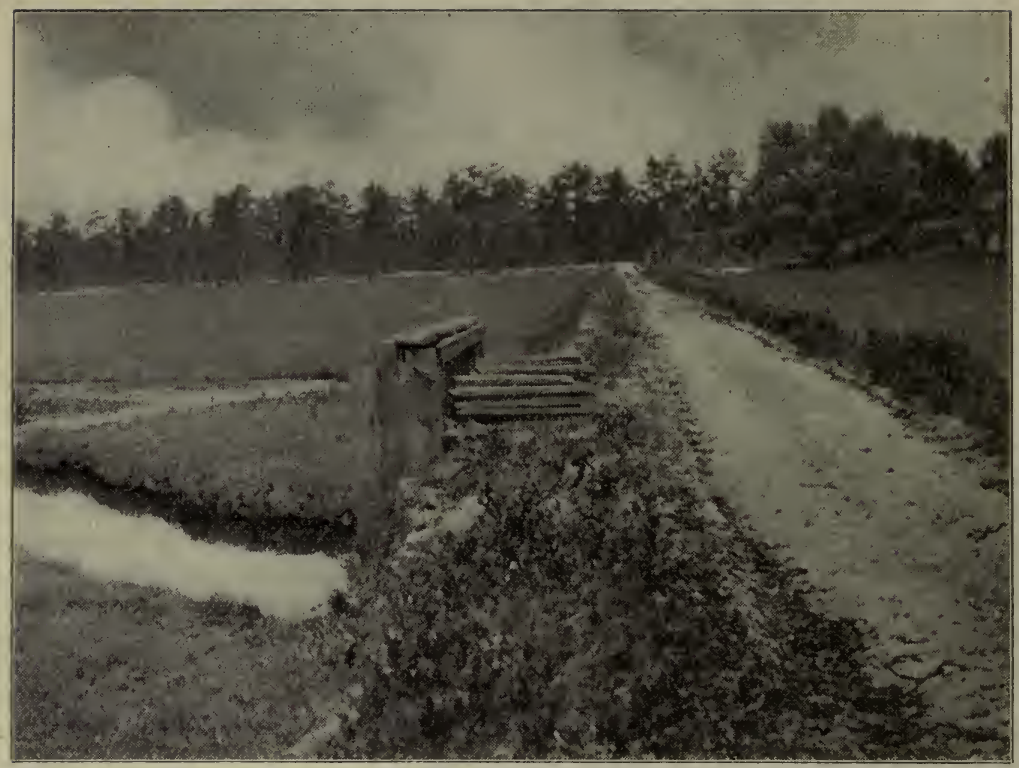

FIG. 30.-DITCH BLASTED WITH DYNAMITE. RIDER CRANBERRY BOGS, HAMMONTON, N. J.

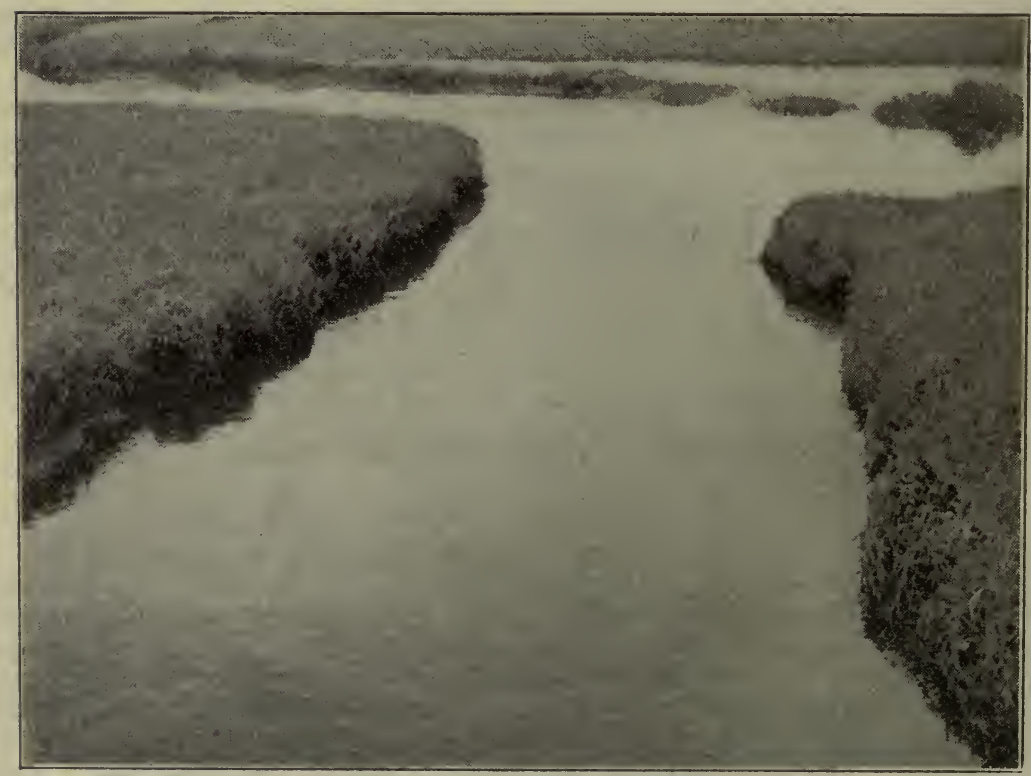

FIG. 3r.-ANOTHER DYNAMITED DITCH ON RIDER BOGS 


\section{Ditching Cranberry Bogs}

This class of ditching differs from the ordinary because what is required is not merely a means of removing surplus water from land, but also a means of flooding the same land several times a year.

The sort of land best adapted for cranberry culture is ideal for ditching with dynamite because wet and heavy.

The method used is by propagated blast from a central detonator, no blasting machine or electric fuzes being required.

The letter printed below is from one of the country's leading cranberry growers and a pioneer in the use of dynamite for ditching, he having successfully used it for twenty years. At the 1911 annual meeting of the American Cranberry Growers Association, Mr. Rider stated he had never experienced any casualties in using dynamite and considered it safer to handle than gasoline.

Note his statement regarding effect of blasting on fungus. This bears out similar experiences of orchardists.

\section{Dynamite Successfully Used for Twenty Years in Cranberry Growing}

Mr. A. J. Rider, Secretary of the American Cranberry Growers' Association, of Hammonton, N. J., writes:

I have used dynamite in the development of my cranberry enterprises with success and economy for the past twenty years. In removing obstructions from water courses, opening ditches and preparing the way for dams and flood-gates, it is especially useful. I keep a supply on hand at all times, and my foremen are all instructed in its use. The saving in time and labor thus effected is very great.

Dynamite will make a straight ditch and under conditions with which nothing but a dredging machine could cope. In excavating for flood-gates the mud walls are temporarily packed so solidly that water hardly seeps through. A crowbar and a stick of dynamite will stop a leak in a dam that would otherwise require hours, and possibly days of labor. All cranberry plants are susceptible to fungus diseases, and much experimenting has been done by growers and government experts to control this enemy. Without being able to give scientific reasons I owe it to dynamite that there has never been fungus growth at Hampton, one of my largest plantations, where I have used it freely.

If the advantages to be obtained through the use of dynamite were brought to the attention of all large cranberry growers I believe you would be doing them a great service.

$$
\text { Very truly yours, }
$$

A. J. RIDER.

\section{Ditching With Dynamite Costs $1 / 4$ Ordinary Method}

\section{St. Louis, Mo., February 8, 1912.}

We take pleasure in advising you that in the month of November, 1911, we dug a ditch with dynamite-about 500 yards long, 10 feet wide and 4 feet deep. The result was very satisfactory and gratifying, and the cost was not much more than one-fourth of digging the ditch by ordinary methods.

If you have any prospective patrons in this section of the country, will take great pleasure in giving them the facts, and if they care to, showing them the result of the ditching done by us.

Very truly yours,

ISLAND REALTY AND INVESTMENT CO. 


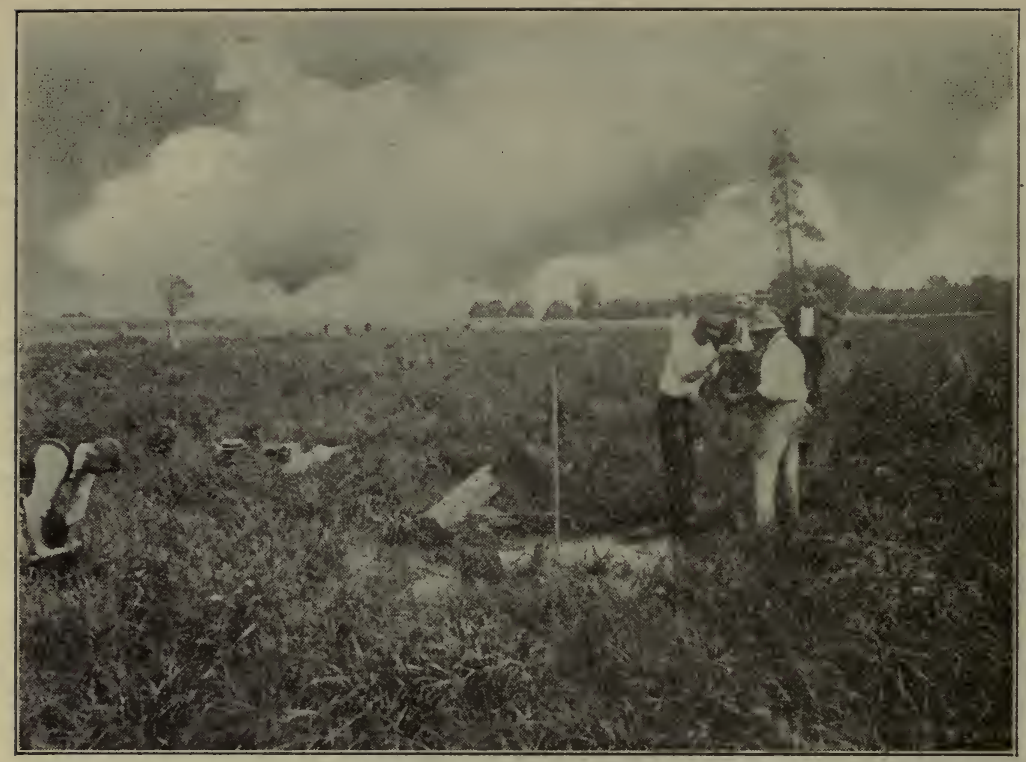

FIG. 32.-PLACING CHARGE FOR DRAINING POND AT NEWARK, DEL.

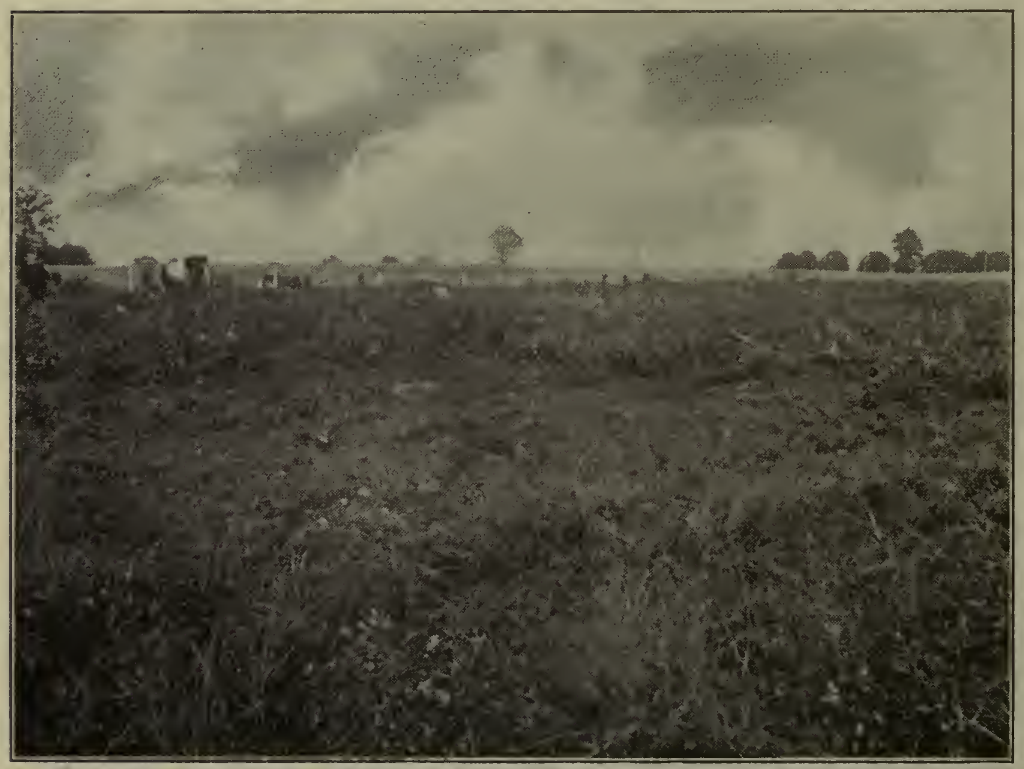

FIG. 33.-A FEW MINUTES AFTER THE BLAST OF POND 


\section{Draining Frog Ponds or Wet Spots}

Swamps and ponds, except where they are close to rivers, lakes or the ocean, are caused by spring or surface water collecting on low ground without a lower outlet and which is underlaid by clay or other subsoil that the water cannot sink through. When it is not practicable to drain these swamps by ditching they can often be permanently dried up by shattering the impervious subsoil in the lowest places with dynamite.

\section{Former Pond Yields $\$ 75$ per Acre Crop}

UNITED STATES DEPARTMENT OF AGRICULTURE. BUREAU OF PLANT INDUSTRY,

Washington, D. C.

Office of Farmers' Co-operative Demonstration Work. Morrillton, ARK., Jan. 18, 1912.

E. I. du Pont de Nemolrs Powder Co.

Wilmington, Del.

\section{Gentlemen:}

As per your request, I here give you my experience with dynamite as a water sinker in my field in Georgia.

I had a lime sink in my field and the water would collect in that basin and would cover about one acre and a half of ground, so some years when we had excessive rainfall I could not plant it to anything.

My brother came to see me on a visit and he said: "Why don't you put down a hole 25 or 35 feet and shoot it with dynamite and sink the water?" So I put down a hole $23 \mathrm{ft}$. and shot it, and it sunk the water.

I weighed the corn that I gathered from the $11 / 2$ acres the first year and I got a few pounds more than 100 bushels of just as goud corn as I have made in my life. This made more than $\$ 75.00$, whereas I had been getting nothing from this land, besides it was very disagreeable to have to work around this wet spot each year.

That was the only year I gathered the corn separately, although it seemed to be better every year I cultivated it until I sold the farm, and I do know that the land worked better every year. This experience of mine, and the results which I secured is what makes me recommend subsoiling with dynamite so strongly. Yours very truly,

JOHN W. PARLIN, Special Agent.

FIG 34 BLASTING THE POND SHOWN ON OPPOSITE PAGE

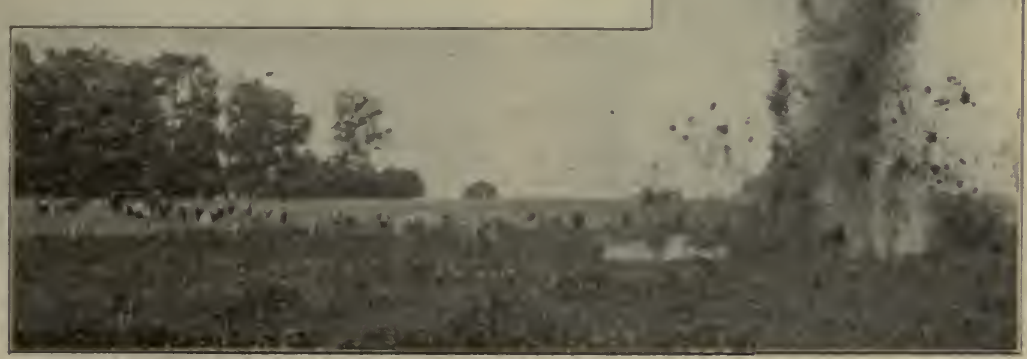




\title{
Ditching With Dynamite Endorsed by High Authority
}

\author{
UPPER PENINSULA STATION \\ Leo M. Geismar, Supt. \\ Michigan EXPERIMENT Station
}

Сhatham, Mich., March 11, 1912.

I have used many tons of dynamite within the past twenty years, both in removing stumps and for breaking up large boulders, and having never seen dynamite used for digging ditches, I became interested in a demonstration which your Company made in this neighborhood last summer. The test was made on a side hill underlaid with a ledge of magnesian limestone about five feet below the surface. Springs about half-way up the side hill kept the lower half of the hill and about six acres of the level ground below in an extremely wet condition. The soil is a sandy loam which contains a few small boulders and many large, flat stones thrown into various positions and weighing from 20 to sometimes over 150 pounds each. Hand digging in such ground is necessarily slow, for ditches have to be dug wide at the bottom to keep from caving in, and many large stones must be either broken up or removed with crowbars. There are several of these side hills in this neighborhood, and two men rarely average more than a rod and a half a day in digging ditches on such ground.

To cut the water off, a ditch four rods long was blasted out with dynamite, the amount used being evidently more than would have been necessary, for it not only opened a ditch of ample width, but shattered nearly a foot of the solid ledge of rock in the bottom. The cost was as follows:

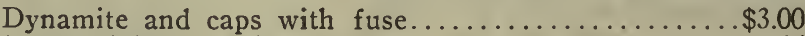

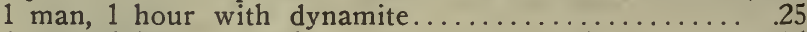

1 man, 2 hours cleaning out bottom of ditch....... .35

Total......................... $\$ 3.60$ or 90 c. à rod

With two men digging one and a half rods a day and getting each $\$ 1.75$ a day, the cost per rod would have been $\$ 2.33$ or over two and a half times more than the cost of digging with dynamite. This demonstration convinces me that on ordinary ground, especially heavy clay, the cost of digging with dynamite must be less than one-half the cost of hand digging. Furthermore, the work of digging with dynamite is done so rapidly that the advantage thereof cannot well be overlooked.

$$
\text { Very respectfully yours, LEO M. GEISMAR, Supt. }
$$

\section{Underdrainage Increases Land Value $\$ 100.00$ per Acre}

Fayetteville, N. Y., Nov. 4, 1911.

You may be interested in learning that $I$ had about six acres of worthless land, which was mostly bog and trash, that has been successfully drained with Red Cross Dynamite.

This land was always covered with water, due undoubtedly to a stratum of shale limestone underneath, but by drilling down through this limestone from 8 to 12 feet deep at the lowest spots in the swamp, "I not only succeeded in draining the entire six acres, but since then it has been planted to corn and potatoes and now to alfalfa, which is yielding as high as five tons per acre.

The cost of this draining work was about $\$ 100.00$ including cleaning up the brush, etc., which I consider most economical. In fact, I could not have drained this bog economically excepting by the use of dynamite.

I might also add that the value of this land has been increased from practically nothing to $\$ 100.00$ per acre.

Yours very truly,

F. E. DAWLEY. 


\section{Tree Planting and Orchard Rejuvenation With Red Cross Dynamite}

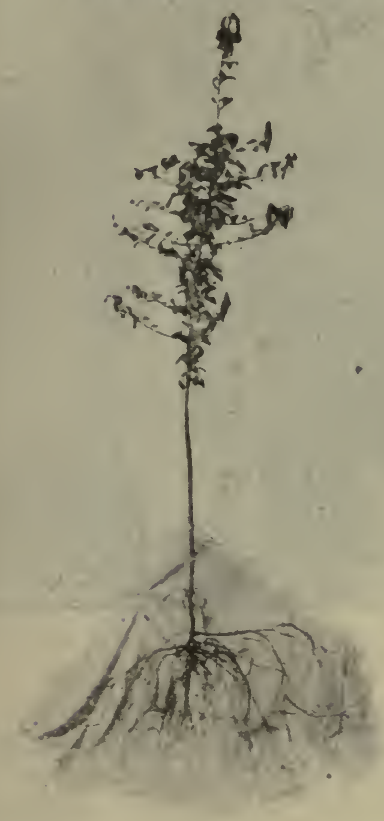

FIG. 35

Planted with Dynamite

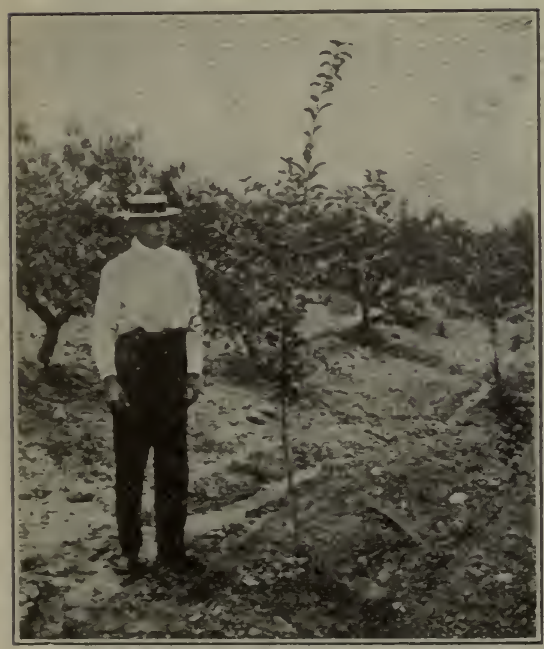

FIG. 37

Planted with Dynamite

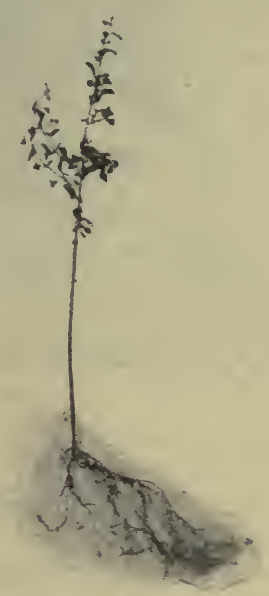

Fig. 36

Planted with Spade

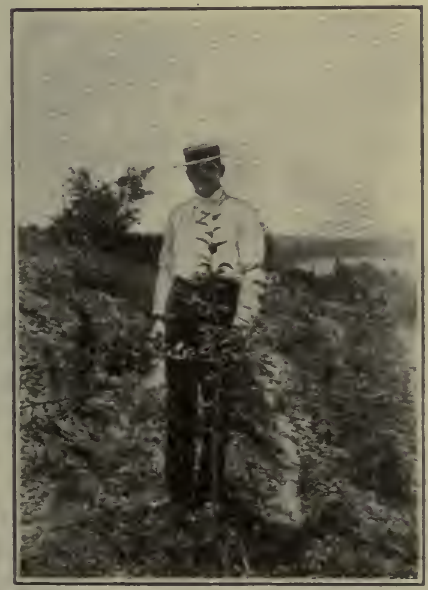

FIG. 38

Planted with Spade

One-Year-Old Apple Trees (In Ground and Dug Out) on Farm of E. G. Sexton, Canton, Ga. 

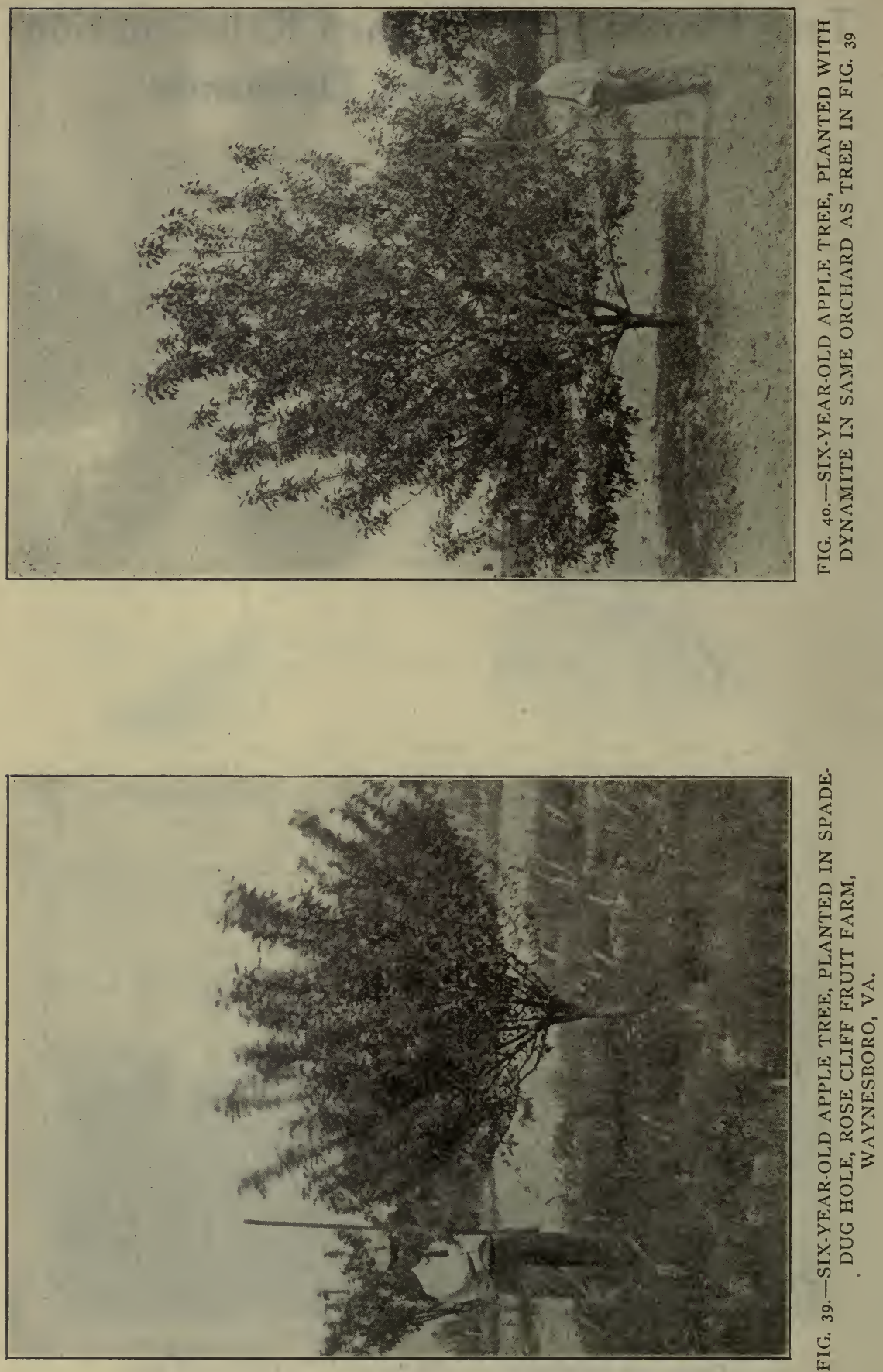


\section{A Revolution in Orcharding}

More than twenty years ago orchardists in California and in other states where hardpan is encountered, blasted tree-holes with dynamite to save the labor of digging them.

This practice led to the discovery that fruit trees set in dynamited holes developed much more rapidly than those set in spaded holes. They lived through drouths when others died. They came into bearing one to two years earlier than spade-set trees. They produced more and better fruit. Today the leading orchardists and nurserymen all use dynamite both for planting new trees and cultivating old ones, in all except loose, sandy soils.

Dynamite has almost entirely eliminated the gambling chances of orcharding. Even the frost-resisting qualities of dynamite-set trees are greater than those of spade-set trees.

In 1911 millions of fruit and nut trees were planted with dynamite.

In 1912 the number will probably be doubled or trebled.

In addition, the many millions of fruit and nut trees spade-set one to twenty years ago, may be forwarded in development or regenerated by dynamite.

Thus we are passing through an epoch of revolution in orcharding that means much to both grower and public.

\section{Proved Results From the Use of Dynamite:}

1. More Economical Than Any Other Method Because-

(a) The actual cost of planting is little if any greater than with spade.

(b) Dynamiting almost entirely prevents the big first year loss common to spade-set trees.

2. More Productive Than Any Other Method Because-

(a) Dynamite-set trees bear marketable fruit one to two years sooner than spade-set trees.

(b) The quantity of fruit is greater than on spade-set trees.

(c) The quality and color of fruit is better.

\section{The Principles of Plant Growth}

It has been conclusively proven that dynamite is an exceedingly valuable aid in the successful growing of trees. Those who have tried it are thoroughly. convinced that no method of excavating the hole in which to plant a young tree is so economical, quick, or productive of desirable after-results as blasting with dynamite. We use the word "economical" in the sense described in our article regarding costs on page 53 . 

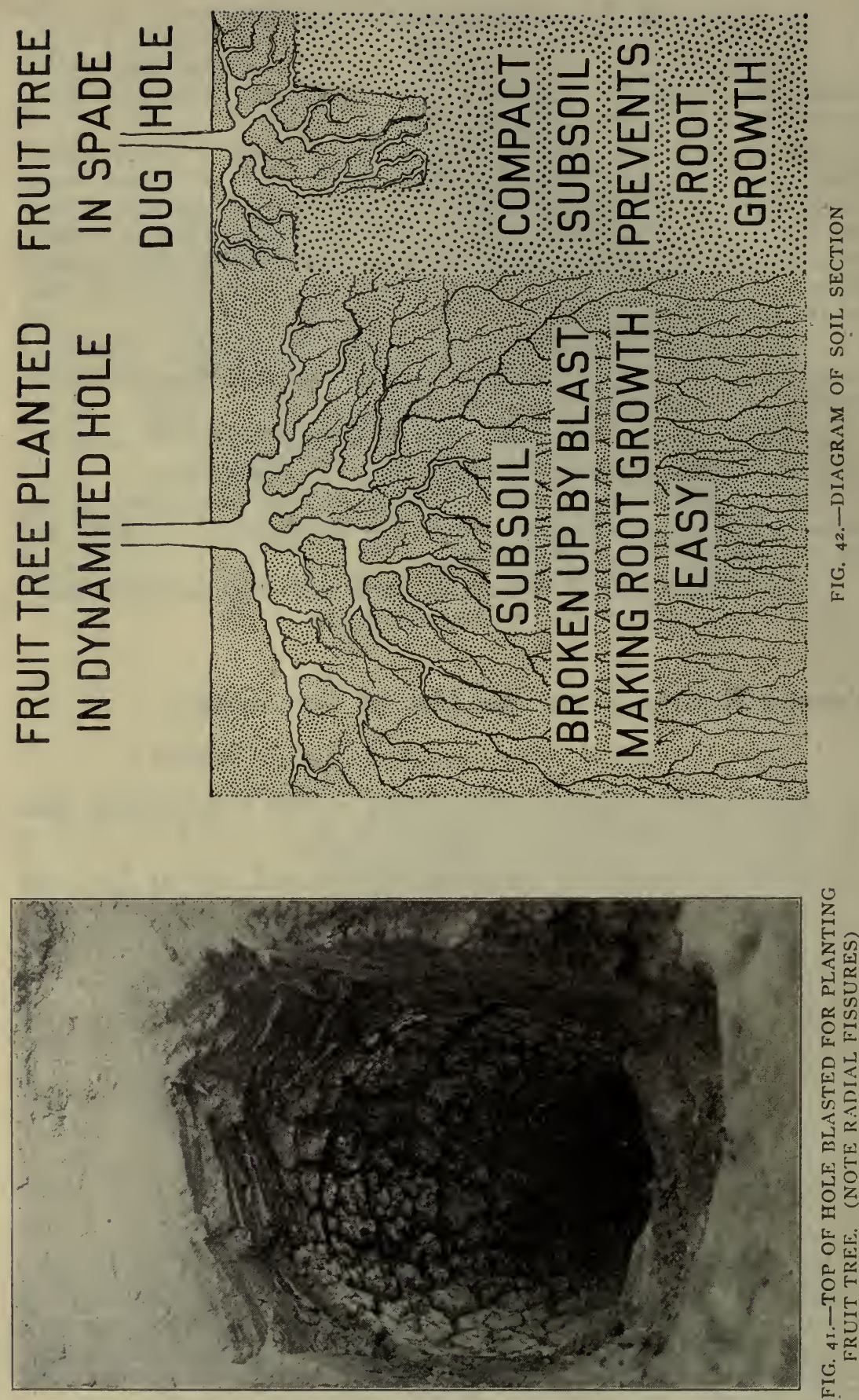
Sometime ago it was the prevailing idea that dynamite was unnecessary for tree planting unless the soil chanced to be underlaid with hardpan, in which case the explosive was regarded as valuable for breaking up the hard soil. It has been found by experiment however, that trees thrive better when planted in blasted holes than in hand-dug holes if there is underlying hardpan, or clay, clay loam or silty loams that are liable to become hard or impervious.

The explanation of this is simple. It is because the explosion of the dynamite loosens up the soil for yards around the spot, and thus makes root growth easy; whereas, digging the hole with tools tends to pack the earth around the sides and at the bottom of the hole and retard root growth.

Scientific agriculturists have discovered that water is the most important element in all kinds of plant growth. It forms a major portion of the green weight of the roots, trunk, branches, twigs; leaves and fruit of the plant. The proportion of moisture will, of course, vary in the different parts. The roots will be found to contain more moisture than the trunk, and the branches, twigs and fruit a larger percentage than the hard wood parts.

Water or soil moisture is the carrier of the tree's plant food. It also influences the temperature of the plant. In dry hot weather the evaporation of large amounts of water from the leaves of a tree has a slightly refrigerating action. It requires more heat units to raise a given weight of water one degree in temperature than it requires to cause a similar increase in the same weight of wood or stone. This is effective in saving trees from immediate harm due to quick changes of temperature. Moisture also has the effect of maintaining the stiffness of the more succulent parts of the plant. A good illustration of this is the noticeable withering of corn and other plant leaves when the supply of moisture is insufficient. Lack of moisture is just as effective in retarding the development of leaves of trees, but it is not so noticeable. Soil which is of the natural consistency to allow water to circulate freely through it and still retain or conserve it so that it is available at all times for growing plants, may be considered as ideal for agricultural purposes. Few soils possess this natural consistency. Other soils, which may be classified as good, average, or fair, must have artificial preparation in order to make them produce the result; that may be expected from the rarely-found perfect natural soil.

Few persons understand the principle of plant growth. It is not necessary, as many suppose, that the root of a plant shall come in actual contact with all of the plant food elements of the soil needed for the sustenance of the plant or tree. Plant roots have the power to draw from the surrounding soil the necessary elements of plant food, provided the soil is of such a character as to permit the passage of these elements through it. Water or moisture is the carrier of these plantfood elements through the soil and into the plant roots. This will indicate the importance of a porous soil which will permit the free passage of water through it in order that plants growing upon the surface may be properly nurtured for rapid and healthy growth. 


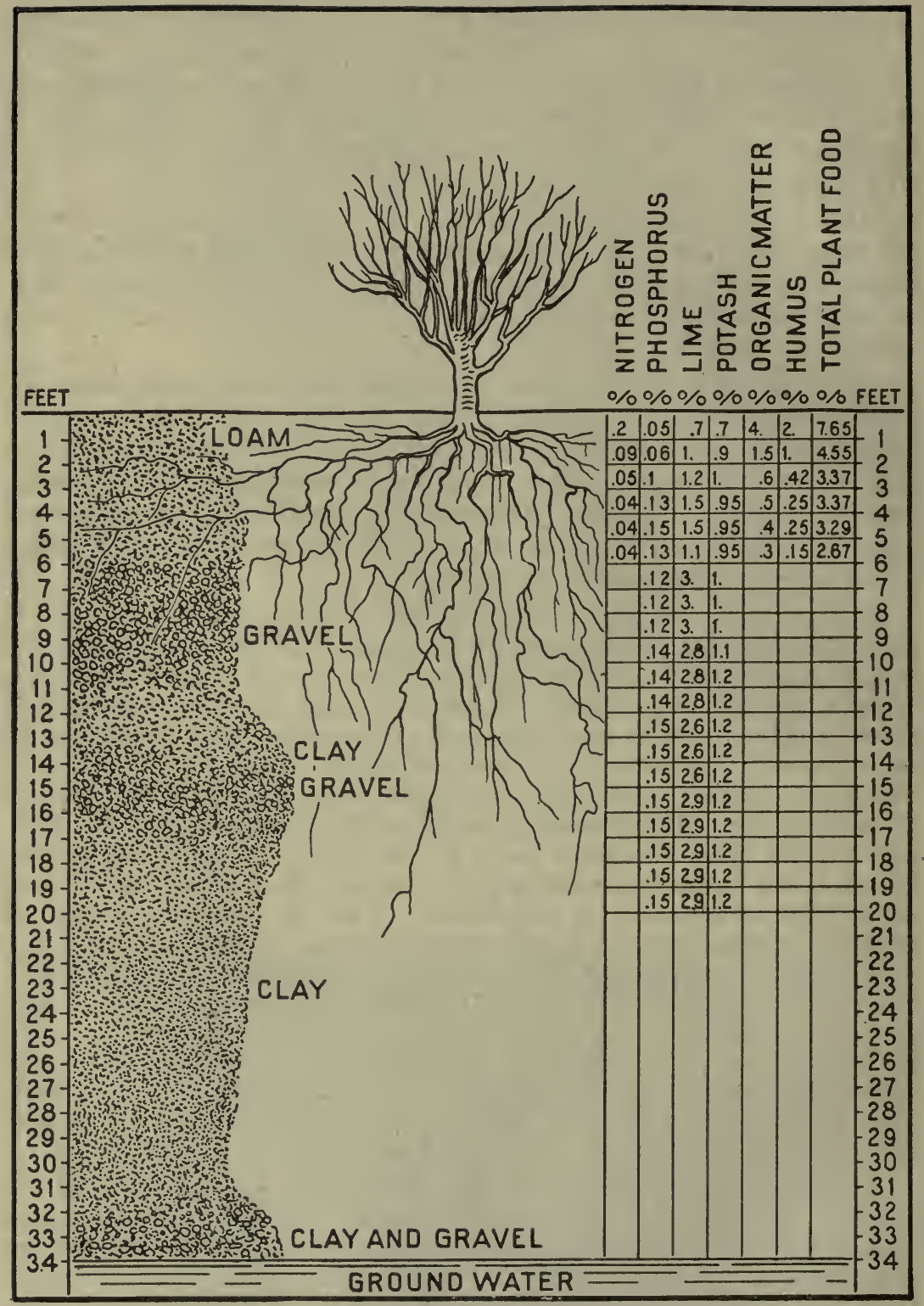

FIG. 43

Soil section showing downward growth of roots to 21 feet, and percentages of various plant foods at different depths. As the drawing and tables were obtained from different sources, the percentages do not indicate those in the soil in the drawing, but are composite percentages from analyses of different soils. 
This, together with the fact that the action of an explosive on soil causes it to become thoroughly mellowed and aerated, causes trees planted in blasted holes to show much stronger and healthier growth than trees planted under old conditions.

In order to give those who may not understand the subject an idea of the scientific principles of plant growth, we will quote W. J. Spillman, Agriculturist in charge of Farm Management Investigations, Bureau of Plant Industries, U. S. Department of Agriculture. He says in a recent bulletin:

"Plant food is dissolved in water. While a plant is growing, a constant stream of water flows up through it and evaporates at its leaves. For every pound of increase in dry matter made by the plant, from 300 to 500 pounds of water flow up through it.

"Plants in their growth make use of thirteen elements, nine of which they secure directly from the soil. These are called the mineral plant foods. They are phosphorus, potassium, calcium, magnesium, sodium, iron, silica, chlorin and sulphur. Soil consists mainly of small particles of rock. Nearly all kinds contain more or less of these mineral plant foods. Every year the soil water dissolves off a thin surface layer from each particle and plants appropriate this water, thus securing their mineral plant food. Hydrogen, another important element of plant food, is also secured from water.

"In order to produce a ton of hay on an acre of land, it is necessary that the growing grass pump up from that ground approximately 500 tons of water. In order to supply this enormous quantity of water, the soil must not only be in a condition to absorb and hold water well, but must be porous enough to permit water to flow freely through it.

"In addition to acting as a water carrier for plant life, soil must permit a proper circulation of air through it. Nearly half of the volume of ordinary soils is occupied by air spaces. Soil which becomes so compact as to stop the air passages, is too wet for most crops and needs drainage, for plant roots must be supplied with air and the soil must be porous enough to permit of its free circulation. One of the most important objects of plowing is to loosen up the soil and mix fresh air with it."

Orchardists and nurserymen who have had long experience in planting trees in holes prepared by dynamite blasts, have learned that compact subsoil is broken up by the blasts, which enable the land, thus made porous, to absorb plenty of water in rainy weather and store it up for the use of growing plants in dry weather. As Mr. Spillman says, this water in ascending to the plant roots carries with it the many necessary soluble fertilizing elements.

Few persons realize the depth of tree root expansion. In one of the "Farmers' Bulletins" issued by the United States Department of Agriculture, a cross section of orchard land is shown which we reproduce on the opposite page. Note the scale on the sides, indicating that this tree has sent its roots downward 21 feet into the soil. This is natural growth. Under normal conditions a healthy tree will seek its food in this way; but suppose a layer of hardpan or compact subsoil is encountered at a depth of two to six feet? The roots must then spread out near the surface for twenty feet or more. The result of 
this unnatural sidewise growth is that each tree in the orchard is compelled to go over into the feeding supply of its neighbor and consequently does not receive the necessary amount of plant food to properly nurture it and allow of its healthy growth. Its yield of fruit is also lessened by this forced encroaching of one tree on the feeding ground of its neighbor. Then, too, a brief dry spell exhausts all the moisture from the thin feeding ground of the tree, stopping its growth or killing it. From this it is not to be assumed that natural lateral growth is undesirable, but simply means that hardpan prevents practically all downward growth. A tree growing under these conditions is also quite likely to be blown over by wind.

Dynamite blasting proves a simple and effective remedy for this condition. The blast breaks up the hard soil and permits the roots to take their natural downward course into the lower strata in which plenty of plant food elements are available. Under these conditions, one tree is not interfered with by another; each one receives the benefit of all of the soil allotted to it when at the time of planting the surface was measured and laid out.

It must not be assumed that dynamite blasting is beneficial only when the topsoil is underlaid with hardpan. It is of the utmost importance to assist a tree, especially a young one, to send its roots out into its feeding bed as easily and rapidly as possible. The more porous and mellow the soil, provided it is one of the type of soils liable to be found in compact condition, the more rapid will be the growth. Even in the deep loamy soils of Oregon, among the most perfect for fruit tree culture found in the United States, blasting has proven extremely beneficial in forwarding the growth of young fruit trees, as is shown in the letter of Orchardist Rawley, which appears on page 63 of this booklet.

The main object to be sought in tree planting is to so prepare the ground that the growing tree can absorb the largest possible percentage of moisture from the soil which it occupies. Loosening and aerating the soil permits it to absorb more of the rainfall and store it against the future needs of the tree. A Cornell University authority advises that a tree planted in soil properly prepared, can absorb 60 per cent. of the moisture contained in it.

Professor Fabian Garcia, of the New Mexico Agricultural Experiment Station, who has conducted a considerable amount of experimental work, much of which was in an intensely practical way, makes the following statement:

"The hope and desire of every orchardist is to have the roots of his fruit trees grow down as deeply as possible. There is no doubt that the deeper the roots grow the better it is for the trees, and the longer lived they are."

\section{Dynamite Method is Most Economical}

Most fruit growers who have tried dynamite for tree planting are ready to admit that the method is productive of good results, and that the work can be done more quickly than by old-fashioned methods.

Many hesitate to adopt it, however, because they reason that it is more costly. There are some features of this question of cost that deserve serious consideration. Many people deceive themselves when they attempt to figure costs. 


\section{Dynamite Prevents the Big First Year Loss}

According to those who have used dynamite for tree planting, the loss from death of trees planted in that way is considerably lower than when trees are planted in spade-dug holes.

Mr. J. H. Baird, Superintendent of the famous Hale Georgia Orchard, of Fort Valley, Ga., one of the most experienced and highly trained orchardists in the United States, says that Mr. Hale's loss of trees planted with dynamite does not exceed 2 per cent., whereas the trees planted on their Georgia properties in the old-fashioned way have suffered losses of around 50 per cent.

\section{Dynamite Saves New Settings, Although Ground Had Never Been Plowed}

Parkersburg, W. VA., July 8, 1911.

Gentlemen.-Our first experience with dynamite in orchard work was during the spring of 1911. The season in this locality has been extremely unfavorable for starting a young orchard. The soil has been unusually dry ever since the trees were planted.

As we considered the use of dynamite in the orchard work in the nature of an experiment, we left a number of checks for comparison. We used dynamite for digging holes for planting of apples, pears, quinces, cherries and plums. In all these, the trees were planted in sod, and the ground was not broken except with dynamite. In other portions of our orchard the same kinds of trees were planted in ground that was carefully plowed and has been since cultivated several times. There is no decided difference in the trees planted by the two methods. Where the trees were planted in sod, however, without the use of dynamite, from sixty to seventy-fiv'e per cent. are dead. Whereas, where the dynamite was used, the loss will not exceed two or three per cent., and in the cases where the loss occurs, the cause is foreign to natural conditions.

In addition to the large fruits above mentioned, we have just recently cultivated a vineyard by putting in small shots one-third of a stick each, every eight feet in the row. We were led to do this a fter seeing what we believe to be decided benefits in its use for planting and cultivating apples and other fruits.

In addition to this, we used dynamite for cultivating, in a limited way, an old orchard. The trees in this orchard are from twenty to thirty years of age. Up to the present season the orchard has been badly neglected. We used one-third of a stick directly under the trunk of the tree, about three and one-half feet deep. The explosion did not disrupt the surface but evidently broke up the subsoil and destroyed the old formation which bound the roots of the trees. This was used early in the season before the trees were in bloom. These trees at this time show a decided advantage over trees in the same orchard under like conditions, which were not so treated. The growth has been at least twenty-five per cent. greater, they are loaded more heavily with fruit than the other trees, the fruit is larger in size, and the leaves and general appearance of the trees indicate a more vigorous thrifty condition. We consider the use of dynamite in the cultivation of an orchard, as above described, one of the most beneficial purposes to which its use is adapted.

Our experience, up to this time, indicates a more extensive use of dynamite in the future. Its use is both expeditious and economical. Its benefits are peculiarly apparent in a dry season like this. By its use the roots of the trees are permitted a greater penetration than would be possible by any other method, thus to a certain extent making the tree independent of surface conditions.

We used, approximately. a ton of dynamite this season, without the slightest accident. The men become familiar with its use and do not consider the labor hazardous.

ROSEMAR ORCHARD COMPANY. 


\section{Dynamiting Highly Endorsed by Chief Moore of U.IS. Weather Bureau}

WIII

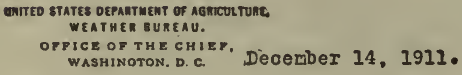

Dear Sir:

I have received your letter of the 13th instant. With regard to the 35 acres I have juat planted with apple and peech trees, ualng dynamite to blow the holes, permit me to say that I found that I oould uge the dynemite with but little, if any more, work than was required to $\mathrm{dig}$ the holes in the ordinary way. I used a force oi five men: one to cut the sticks of dynamite, attach the Iuse, and put on the caps; two to drive bolos with crovbars; one to insert charges and tamp them; and one to explode the charges. This force worked in the forenoon blowing the holes, and in the alternoon they started where they began in the morning shaping up the holcs and planting the trees. They put up from six to seven hundred trees each working day. As a teat 1 shoveled the dirt out of several holes, and found the earth'shattered fine and permeable to a depth of four or five feet and an equal distance in a norizontal direction. I am of the opinion that the trees set in these holes will make the orainary fivo years' growth in three, othex conditions being equal.

Another year I intend to loosen up the sub-soll in a field in which I shall plant corn, for the purpose of making a comparison with an adjacent field that will be planted with-

out the use of dynamite. I look forward to valuable results for the farmer from the use of explosives.

very truly yours, mului Lonore 
From this it is apparent that in considering the question of economy we must go beyond first costs. Assuming that young apple trees, for instance, cost 20 cents apiece, and that 1,000 are planted. If 2 per cent. of them die, the loss will be 20 trees, worth $\$ 4.00$. If 50 per cent. die, the loss will be 500 trees, representing a money loss of $\$ 100.00$, which the dead trees cost. To plant 1,000 trees with dynamite would cost for materials from $\$ 60.00$ to $\$ 65.00$. Leaving labor out of the calculation altogether, the orchardist saves $\$ 96.00$ worth of trees by planting with dynamite. Charging the $\$ 65.00$ blasting cost against that, still leaves him $\$ 31.00$ in pocket in spite of the outlay for dynamite, caps and fuse.

\section{Dynamite Saves Time and Labor}

But that is not the only saving. It seems to be very generally admitted by those who have used dynamite for tree planting that the work can be done much faster by that method than when the holes are prepared with spades. The saving in labor then becomes a large item. If trees are planted according to the most approved horticultural methods - that is, in very large holes dug out to thoroughly pulverize the soil for from two or three feet in every direction from the trunk of the tree, and to a depth of at least two feet-a laborer can plant a tree with dynamite in one-tenth the time it takes to plant it with a spade.

\section{One Blaster Replaces Twenty-five Tree Planters}

The following is quoted from a trade report of a Du Pont Salesman:

"When I called on this party (Dr. J. T. Kelley, of Quicksburg, Va.) he had about 25 men out digging holes and had never thought of using dynamite, although he had heard of it. After talking to him a few minutes I asked him if he would take the time to go over in the field and let me show him how it was done. I had the necessary explosives with me. He gave me the time and I got him to thinking. He asked me to stay all night and give him a chance to think it over. So I stayed and talked over the whole thing with him that night, and before we retired he asked me if I would go with him up the country early in the morning to where he had his men digging and show them all about it. He said if he decided to blow the holes he wanted the men to understand all about it, and that they would understand better if they saw it. By 7.15 we were at the farm and found 25 men working. He called them all to quit work and come and see how we could blow holes. I could not look the men in the face, for I felt it meant their jobs, and after I had shot a hole or two, I heard one fellow say, "That fellow is going to cut us out of our job.' Sequel: In one hour they had all been paid off for a half day's time and sent away."

\section{Dynamited Trees Bear Earlier}

There is also another feature that must be considered in connection with the question of economy-that is, the claim of experienced orchardists that trees come into bearing from one to two years earlier when planted in dynamited holes.

\section{Gained Two Years by Planting with Dynamite}

Gentlemen:-It may be a surprise to you to learn that I have been using dynamite for planting trees for a number of years, and have some shade trees planted in that way eighteen or twenty years ago. They are the finest trees $I$ have ever seen grow for their age. In the planting of peach trees I gained two years in six; in other words, I got as much fruit from a tree planted with dynamite at four years old as we usually get at six years old.

I not only plant them with it, but where a tree is failing and seems to be on the decline I start it off to growing again by firing charges from three to ten feet apart.

Nothing seems to tickle the earth so much as planting watermelons after explosion of dyna. mite from three to four feet under ground. I plant them twenty feet apart each way. Fertilize heavily and the vines bear right on until frost, the entire summer.

W. W. STEVENS, Orchardist, Mayfield, Ga. 


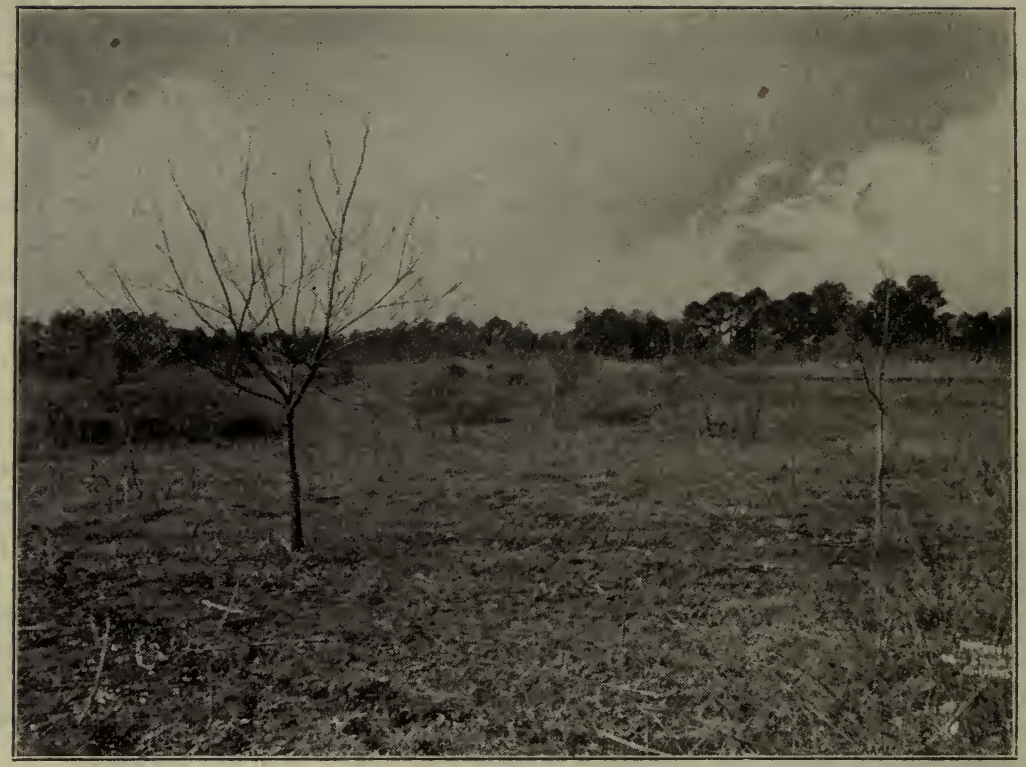

Dynamite-set

FIG. 44

Spade-set

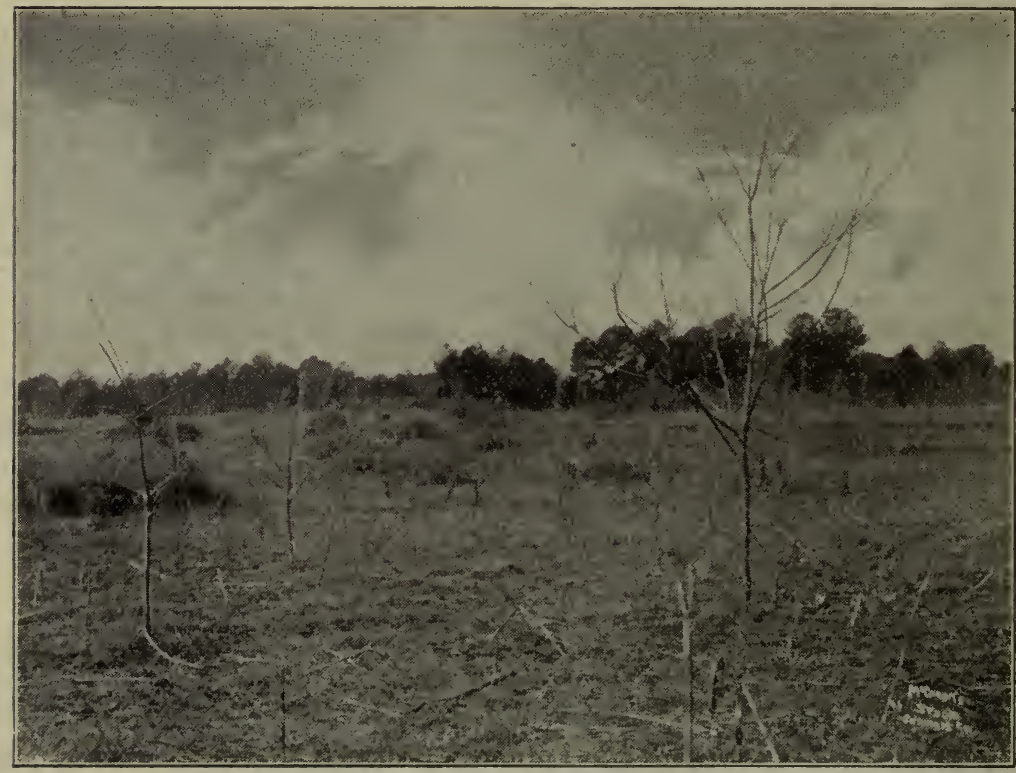

Spade-set

FIG. 45

Dynamite-set

Pecan trees planted Jan., 1906, on land of F. W. Mc.Murrain, Columbus, Ga. 
It is not contended that this more rapid growth is due to the fact that dynamite is a fertilizer, but because the blasting makes the soil thoroughly porous and mellow, and gives the tree roots an opportunity to expand easily; also because the increased moisture-storage capacity of the shattered soil forwards the development of the tree. Therefore, the value of one or two years' crops must be added to the cost of the original tree planting in spade-dug holes, or deducted from the cost of preparing the holes with dynamite. This would more than counterbalance the one to three cents per tree planting cost, which close calculating orchardists regard as the difference between planting in the old-fashioned way and planting with dynamite.

Horticultural experts state that the average tree cannot thrive when it is planted in a little spade-dug hole about the size of a large flower pot.

The proper way to plant a tree with a spade is described in a paper on tree culture read by a horticulturist at the meeting of the Kansas State Horticultural Society, held in Topeka, Kansas, in December, 1909. The following are extracts from the paper:

"The soil should be stirred as deep as it well can be, the deeper the better. In digging your tree holes, forget that you are going to plant a tree, and imagine you are going to bury the largest horse on the place, and dig accordingly. Remember it is the last chance you will have to loosen up that soil, so do a good job. "Plant your trees deep, getting the roots down where it never gets dry."

One of the largest and most successful nurseries in the country is that of the William $\mathrm{H}$. Moon Company, of Morrisville, $\mathrm{Pa}$. In their book, entitled, "How to Plant a Tree," they say: "Holes must be made so large that the roots may spread out naturally without cramping." That means for one and two-year-old nursery stock a hole at least 18 to 24 inches across and nearly as deep. When an inexperienced fruit grower claims to be able to plant a tree for three or four cents per hole, of course he tells the truth. He can; but he can't plant it right for that cost. He can also build a house for $\$ 9.00$, but do you want that kind of a house?

To dig a hole as large as these experts advise, with ordinary tools, would require much time and labor. Half a cartridge of dynamite will loosen up the ground, and make it porous in an instant.

\section{Expert Advice From a Professor of Horticulture}

\section{Deep Rooted Trees Resist Drouth and Frost}

"I believe it is of fundamental importance to plant trees in soil loose and open enough, and well enough drained so the roots can go down deep. For example, the peach trees in the deep loam where they root deep blossom as early in spring as do shallow rooted peach trees in adjacent clay soil. Those in the deep, mellow loam, however, will endure more cold and will set full crops much more frequently than do these same varieties over a hard clay subsoil. The trees mature better, apparently store up more sugars and other materials in their buds for winter, and do not have their fruit buds killed at the same temperature as do trees on hard clay subsoil. We have taken twigs in full bloom, surrounded them with a freezing chamber so as to find out at just what temperature the bloom would be killed. Those growing in the deep well-drained soil will sometimes endure as low as 26 degrees, or 6 degrees below freezing, without the flowers being killed when in full bloom. Similar trees grown where they did not root down well, would not endure drought of summer in as good health, due to the packed subsoil, and often have their flowers killed at 28 to 29 degrees or about 3 degrees below the freezing point of water."

J. C. WHITTEN,

Professor of Horticulture, University of Missouri, Columbia, Mo. 


\title{
Dynamited New Trees Successfully Survived Drouth
}

New Albany, Ind., June 29, 1911.

Gentlemen:-I used dynamite in planting my orchard of more than four thousand trees. I used one-third of a stick of $40 \%$ dynamite for each tree. I drilled a hole for each tree about two feet deep, tamped the dynamite tightly, and exploded each charge with fuse and blasting cap. The explosion loosened the soil within a radius of about four feet to a depth of about thirty-six inches.

With my long experience of planting trees, I find the use of dynamite the most successful method. The loosened soil' acts as a reservoir to hold moisture. I planted my orchard in the spring and find that my loss of dead trees will not exceed 5\%, notwithstanding the fact that we have had a six weeks' drouth, this low percentage being due to the loosened soil holding moisture. Under no circumstances would I think of planting an orchard without the use of dynamite. I recommend it as the cheapest, quickest, most successful and most satisfactory method.

NEWTON A. GREENE, Mayor, City of New Albany, Ind.

\section{Famous Orchardist Uses Dynamite in Planting and Renovating Peach Orchards}

\author{
E. I. Du Pont De Nemours Powder Co., Wilmington, Del. Feb. 22, 1911.
}

Gentlemen:-I am just back from a two weeks' stay in our Georgia Orchards.

While I was there we continued further blasting for the replanting of about 3,000 trees where they had failed in one of our older orchards. I also looked over carefully the two little blocks of trees we planted with dynamite last season and the results are even better than I had been led to believe when I left there the middle of July. In the meantime I am becoming further interested in the matter and in the recommendations for renovating some of the old apple orchards in New England and want my clients to try dynamiting a portion of the land around these trees, especially when they are in particularly strong heavy soil. Yours, J. H. HALE.

NOTE.-Mr. Hale is the owner of several of the largest commercial orchards

in the United States.

Mr. Hale wrote us as follows, December 18, 1911:

Our experiments with the use of dynamite in planting peach trees in our Georgia orchard in 1909, and continued on a larger scale the next two years, are giving us such promising results that I am inclined to go a little further into the matter in planting eight or ten thousand trees down there this winter, and possibly in planting quite a large lot of peach and apple here in Connecticut the coming spring, and so am writing now to know what special prices you can make us on the dynamite, caps, fuse, etc., delivered at Fort Valley, Georgia, as early in the month of January as possible.

J. H. HALE.

\section{Explanatory Note}

Several orchardists who have read our booklet have asked why it is that we recommend our Red Cross 20\% Dynamite for tree planting and orchard rejuvenation, when many of the orchardists who have given us testimonials, which are published in the booklet, speak of having used $40 \%$ grade.

It is because the $20 \%$ grade has not been generally carried in stock by dealers throughout the country up to a very few months ago. The $40 \%$ grade has been more conveniently obtainable and hence more generally used. Of course, the $40 \%$ strength gives very satisfactory results in tree planting, but as our experiments have convinced us that the $20 \%$ grade is fully as good and, under most conditions, a little better and is cheaper than the $40 \%$ grade, we recommend it. 


\section{Dynamite Method is More Productive}

\section{Results of Blasting on Rose Cliff Fruit Farm \\ Dynamite Kills Fungus Diseases \\ Makes Trees Grow Twice as Fast}

Having learned that Mr. James Craig, President of the Rose Cliff Fruit Farm of Waynesboro, Va., had been using dynamite in the tree planting and regeneration work in his extensive orchards for several years, we sent an investigator to obtain his views. The following is a report of the interview:

$\mathrm{Mr}$. Craig is a very progressive fruit grower. $\mathrm{He}$ is one of the first among Eastern orchardists to employ orchard heaters; as a result of this enterprise the fruit on his trees was saved in the spring of 1911, when a heavy frost killed all other fruit in the neighborhood. Mr. Craig has also used dynamite for killing fungus diseases in the ground under and around old trees which have died of fungus diseases. As a result, he has been able to use the ground for replanting, something which has been considered inadvisable previously.

Our representative obtained a number of photographs of trees on Mr. Craig's property, some of which we reproduce in this booklet.

Figure 40 shows a six-year-old apple tree planted in ground prepared by exploding a half cartridge of $40 \%$ strength Dynamite at a depth of eighteen inches.

Figure 39 shows a view of another tree planted in the same month of the same year by the ordinary method of digging a hole with spade and pick. By comparing the height of this tree with the man holding an eight foot rod in his hand, also shown in each picture, the difference in the size of the trees can easily be seen.

Figure 47 shows a nine-year-old tree planted in ground prepared by blasting a half cartridge of $40 \%$ strength Dynamite at a depth of eighteen inches. Figure 46 shows a nine-year-old tree planted in a spade-dug hole. The two trees just referred to are not 200 feet apart.

The soils in both plots shown are practically identical; the trees in these orchards are both of the same species of apple; but, as will be noted from the photographs, the trees planted with dynamite show very good growth, whereas the trees which were not planted with dynamite show up poorly.

In February of $1911 \mathrm{Mr}$. Craig did some blasting in his orchard, midway between his trees, with a view of loosening up the soil. $\mathrm{He}$ used in each hole one-half cartridge of $40 \%$ Red Cross Extra Dynamite, exploded at a depth of eighteen inches. One of the objects of this blasting was to break up some shale underlying a great many of the trees and preventing the deep growth of the roots. To see what results these blasts accomplished, some of the soil was afterwards dug out with shovels. It was discovered that the ground had been broken up at a radius of from six and one-half to eight and one-half feet from the point of the blast, thus giving the tree roots an opportunity for deeper and more healthy expansion. 


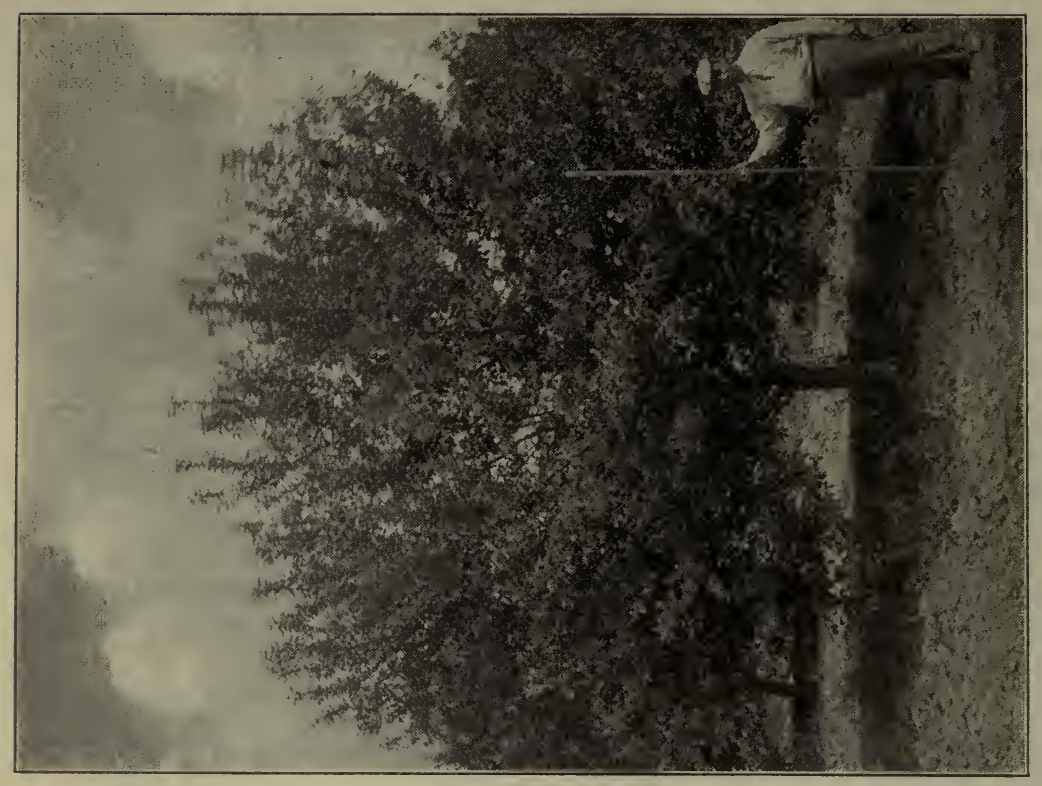

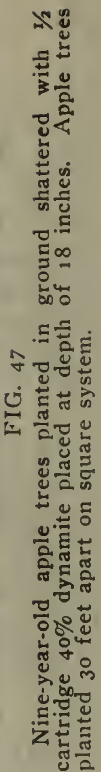

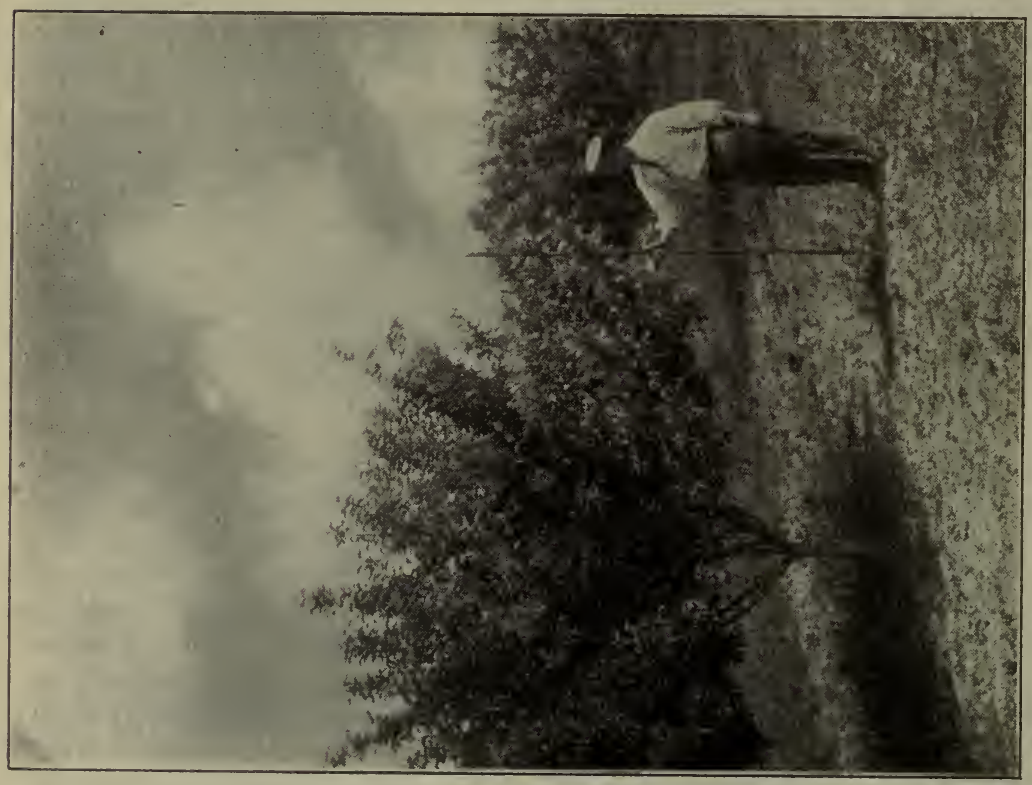

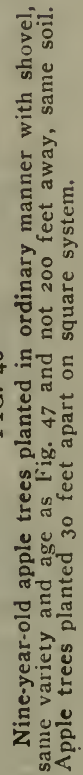




\section{A Controversy Settled}

Mr. James Craig, President, Wilmington, Dei., February, 6, 1912.

Dear Mr. Craig:

Rose Cliff Fruit Farm, Waynesboro, Va.

File A-3718: ROSE CLIFF FRUIT FARM.

Referring to the cuts used in our Tree Planting Booklet (copy of which 1 enclose), showing the comparison in growth between trees planted with spade and with dynamite in your orchard:

These pictures have been criticised by orchardists to some extent, as being an unfair comparison because the dynamited tree is in cultivated ground and the spaded tree is in ground not so well cared for.

1 understand some people who have visited your orchard have also said that the smaller tree had not received the same attention in spraying, pruning, etc., as the larger tree.

Will you be kind enough to advise me whether there is any truth in these statements, and whether you think the pictures we are using are an unfair comparison or not.

I enclose a stamped envelope for reply, and would greatly appreciate your attention to this matter. Very truly yours,

GEORGE FRANK LORD,

Manager Agricultural Division.

Mr. George Frank Lord,

Wilmington, Del.

Waynesboro, Va., February 9, 1912.

Dear Sir:

Your favor of February 6 th received. In regard to the two trees that you make a comparison of, beg to say that there is probably some slight difference in the culture and care of these two trees, yet the care that the small tree has had should have developed as large a tree as the other one, as it has been sprayed well, has been cultivated and has also had two coats of barnyard manure while the other one has not had any barnyard manure at all, yet it has good culture and has been well sprayed. I think if the other tree had been set in a dynamite hole it would have shown practically the same growth. I am sure the ground will grow as fine a tree as the one shown in the picture. Of course it can be criticised and it is right hard to make a comparison of any two trees without showing some difference in the care.

I do not doubt that dynamiting the ground planted to trees is of the greatest advantage possible. The American Apple Company, of which I am VicePresident, set the past May 500 "Delicious" trees on a sloping hillside and without any special care given them except dynamiting (as it was so late in the season we could not get the ground prepared as well as we would have liked), yet these trees have made a very fine growth, as fine as any we have set, and we only lost about three trees in the 500 , yet we had a drought that was unprecedented in this part of the country. This satisfies me conclusively that the blowing of these holes offered a loose pliable ground for many feet around which retained the moisture and in this way the trees did not suffer, but made an immense growth which can be seen by any one visiting us. Yours very truly,

ROSE CLIFF FRUIT FARM, Inc.,

Jam Es CRAIG, President.

\section{Dynamite Used in Largest Peach Orchard in U. S.}

Superintendent J. H. Baird, of the famous Hale Georgia Orchard, of Fort Valley, Georgia, writes under date of May 20th, 1911:

"The trees planted this season with dynamite are growing beautifully and we have not lost any through drouth, while those planted without dynamite have died out badly and show poor growth."

On June 17, 1911, Mr. Baird again writes:

"Vegetation is burning up here for lack of rain, but the young trees have lived beautifully; do not think we have lost over $2 \%$ of those planted with dynamite, while of the others planted in the old fashioned way we have lost from $50 \%$ up." 


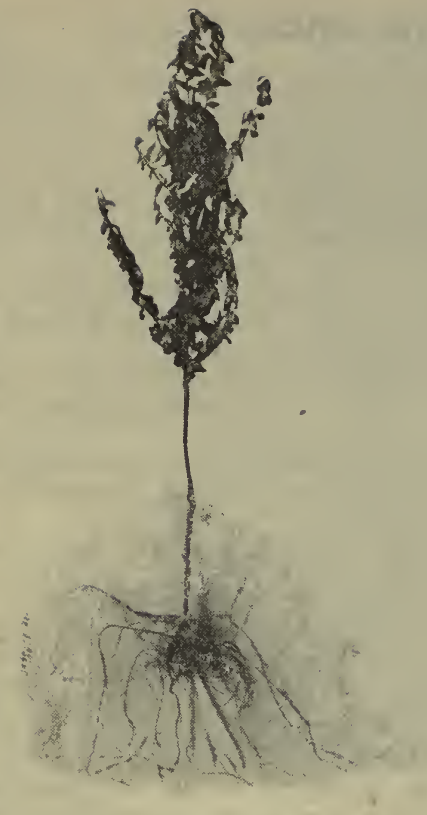

Fig. 48.-Planted with Red Cross Dynamite

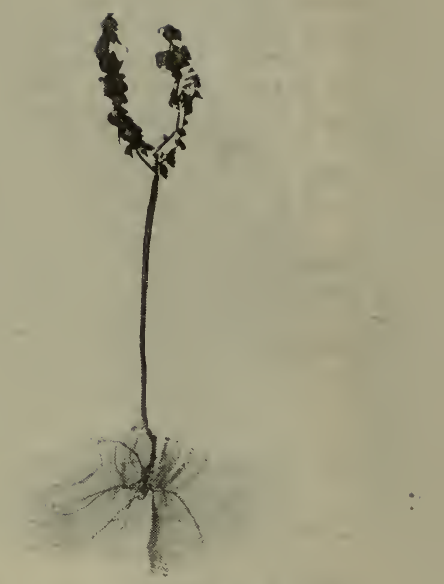

Fig. 49.-1'lanted with Spade

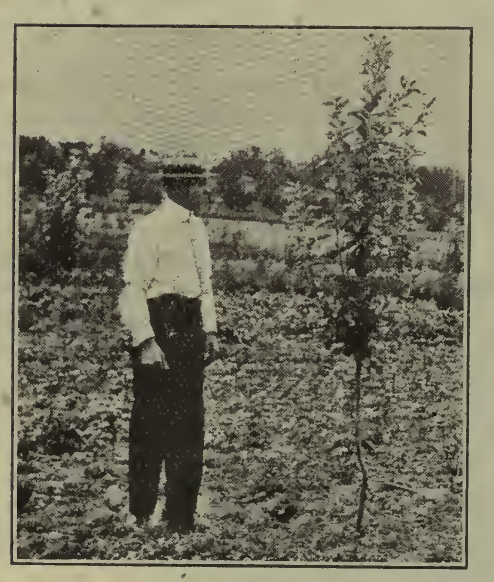

FIG. 50.-Planted with Red Cross Dynamite

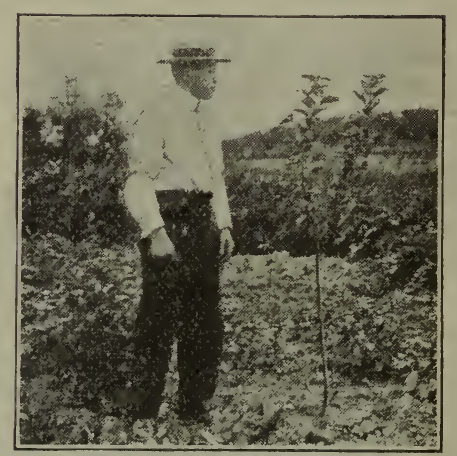

Fig. 51.-Planted with Spade

Two-Year-Old Apple Trees (In Ground and Dug Out) on Farm of E. G. Sexton, Canton, Ga. 


\section{Found That Dynamite Kills Fungus}

Gentlemen :

August 10, 1911.

A few years ago I experimented in planting trees with dynamite. It was a decided success. My neighbors observed the results and now many of them are talking of using this method hereafter. My observations were as follows:

1st. Made new land out of old. It made a drainage for stagnant waters and provision for carrying moisture down in the wet season and up in the dry season by breaking up and pulverizing the soil and establishing a capillary attraction between moisture beneath and air above.

2nd. In resetting an old orchard of diseased or dead trees, it is regarded as fatal to reset, without digging the hole and letting it stand for a year or two. If the old tree is blown out with dynamite and the ground left for a few hours with fumes imbedded, it will kill all fungus, bacteria, grubs, and animal parasites. The tree thus treated will grow and do as well as on virgin soil.

3rd. The tree will have more vigor and vitality, will grow faster, bear earlier, and be more productive and longer lived.

4th. The combined cost of blowing hole and planting tree is but a trifle more than digging hole and planting tree the old way.

\section{Very truly yours,}

J. A. TEAGARDEN, Auburn, Cai.

\section{Kills Fungus}

\section{Arbor Hill, Nurseries, Sales Grounds at Summit Station,} Brownwood, TEx., Nov. 4, 1911.

One experiment I made while at Arlington, Texas, in application of dynamite will no doubt be of interest to you.

In spring of 1910 I planted a number of cherry trees upon a plot of land that was infested in spots by rot fungus; and $I$ happened to plant one of these cherry trees in one of those spots; said tree was dead by the first of June, 1910 , with roots rotted.

Last winter I placed a stick of dynamite about 30 inches deep in the same identical spot, exploded it and immediately planted another cherry tree, which grew well during all the past summer and fall without showing any indication of root rot.

I believe the organism of root rot disease is delicate enough that a shock occasioned by explosion of dynamite will destroy it within considerable distance of centre of explosion.

$$
\text { Very truly yours, }
$$

CHAS. F. WARD.

\section{Two Men and Dynamite One Day Better Than Three Men One Week Without.Dynamite}

\section{Dear Sirs:}
A. F. Bornot Bro. Co., 17th Street and Fairmount Avenue, Philadelphia, Pa., April 26, 1911.

Your Mr. Fulmer was here Monday and together we made about one hundred holes which has enabled my gardener to plant one hundred peach trees the following day. Three men could not have done the same amount of work in a week. The ground is now very loose; I am more than pleased and would not plant another tree on my place without explosives.

Very respectfully,

A. F. BORNOT BRO. CO.

L. 


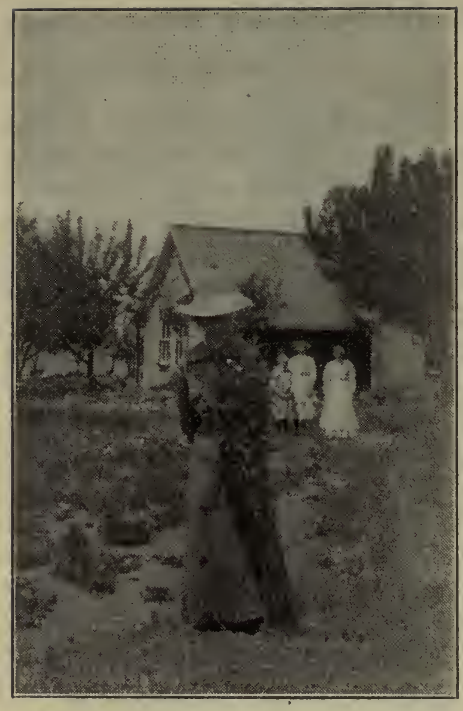

FIG. 52

Two-Year-Old Apple Tree Set in Spaded Hole

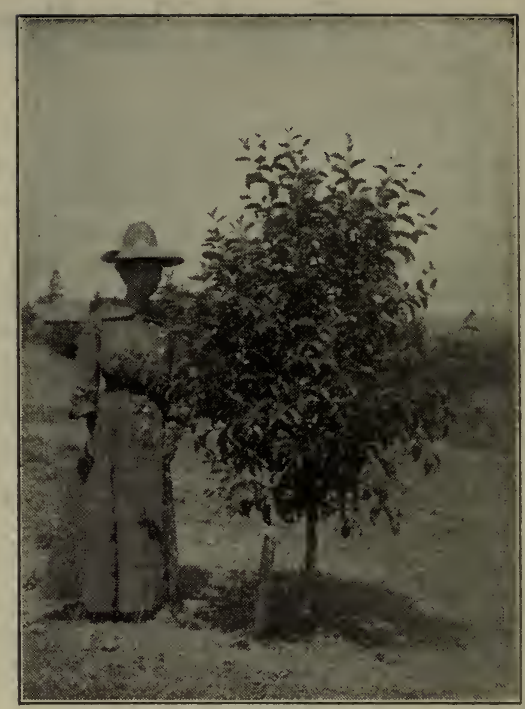

Fig. 53

Two-Year-Old Apple Tree Set in Dynamited Hole

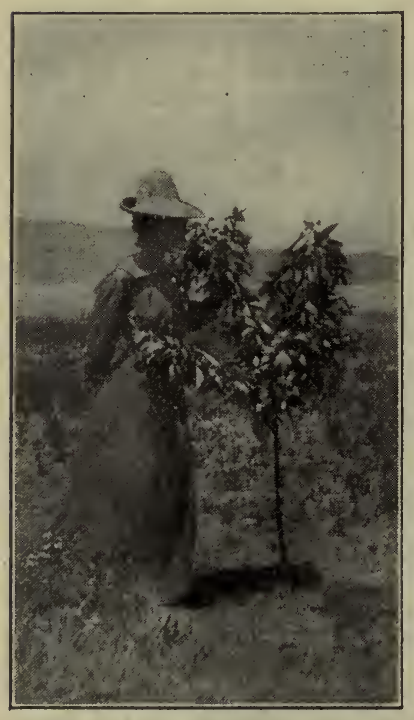

Fig. 54

Bing Cherry Tree, Two Years Old, Set in Spaded Hole

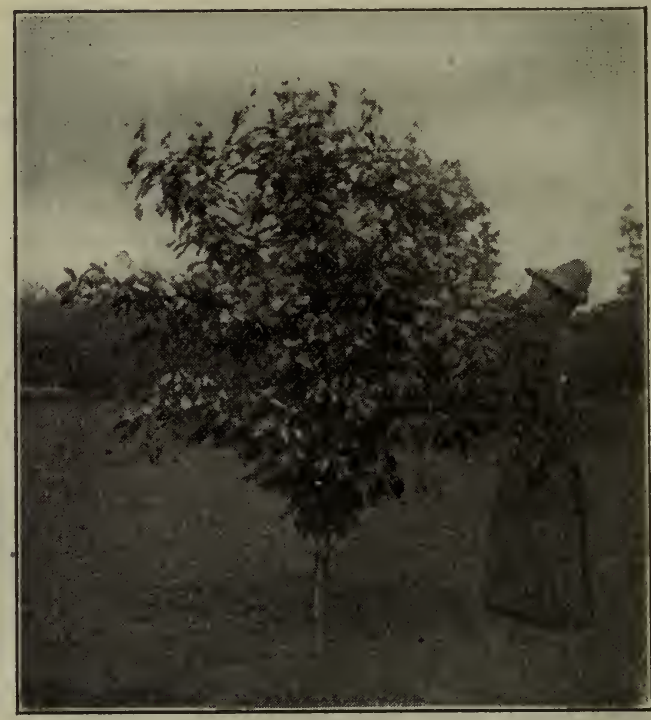

FIG. 55

Bing Cherry Tree, Two Years Old, Set in Dynamited Hole 


\section{Dynamite Tree Planting Shows Fine Results In Five Feet Oregon Loam}

Grants Pass, Oregon, May 12, 1911.

Gentlemen:-I am sending you photographs of four trees.

Figs. 52 and 53 are Bellfower apple trees; Fig. 52 was set in a spade-dug hole, and Fig. 53 in a dynamited hole.

Figs. 54 and 55 are Bing cherry trees; Fig. 54 was set in a spade-dug hole, and Fig. 55 in a dynamited hole.

These four trees were part of a shipment of year old nursery stock received and set out the latter part of March, 1909. The photographs were taken about the I5th of April, 1911, two years after setting out, just as they were coming into leaf.

Bellflower apple tree (Fig. 53) was pinched back in June, 1909, about ten weeks after planting. It was shortened in by removing some two feet of growth from each main lateral the following November. In I9ro it had the same treatment. It is a very vigorous tree with healthy foliage and fine color.

Bellflower apple tree (Fig. 52) had as good ground to grow in, but was spade-set and made such small growth it needed neither pincling back nor pruning. Not a bit of growth, not a leaf has been removed from the head of this tree since planting. The trunk is less than half inch in diameter, while the dynamite-set mate to it has several branches thicker and finer than the trunk of Fig. 52.

The Bing cherry trees (Figs. 54 and 55) have the same identical history as Bellflower apples (I'igs. 52 and 53 ) with the exception that we did not shorten in at fall pruning (Fig. 55) as much as we did apple No. 53 .

We have heavier tops and taller trees of these varieties in the orchard, but these trees are two favorites, very typical of their kind and strike a favorable average for the lot of five hundred. From 250 apple trees so set we got a perfect stand, not one died.

We use dynamite for making holes in planting trees on our very best and deepest ground, as well as the poor spots. It is much cheaper than hand labor, it is much quicker when speed is a most important point and delay will cause the loss of many trees. It insures every ad. vantage to the tree getting a good start.

After the orchard is staked, one man with a shovel removes a circle of surface soil from about the stake, usually five cuts or so, which is laid to one side to use in filling the bole to proper level before setting the tree with the roots carefully pruned back.

A second man follows the first with a crowbar and works the hole down where the stake comes out. If a stone or anything of the sort is encountered we dig it out. If a spot of hard sediment or hardpan is encountered the hole is put through. These holes are about eighteen inches deep. We use one stick of dynamite properly fitted with 18 inches of best fuse for the average hole. It is dropped to the bottom of the hole and tamped down, then the fuse is lighted. There is very little stuff thrown up, the force going downward and outward. The holes are allowed to stand probably over night, or part of the next day, are probed with a crowbar, and, if satisfactory, the sides are broken in, the top earth at one side filled in, and the hole is ready for the tree.

We have set all our trees in wet weather, which insures a storage of moisture under the tree. If one were compelled to set in dry earth, a generous supply of water should be added to settle the hole prior to throwing on top earth that makes the bed for the tree to set on. Twice each spring a circle should be worked up to a fine mulch about the depth of a spading fork, and kept loose, unbaked and free of weeds.

Last November we liad occasion to remove some fller trees, Grimes Golden apples, seven months after setting out, one of which was spade-set. They were taken up with the greatest care so we could get the roots out intact iust to prove to ourselves what difference in root growth we would find in same variety, in perfectly matched trees on the same ground from the two methods of setting.

The spade-set tree had a fine bushy and vigorous tassel of roots about a foot long. The dynamite-set tree had two roots going down some three feet. I held it out at arm's length, my hand clasped around the graft scar, and the roots touched the earth. Also it had a great quantity of medium and short growth roots. The difference was so convincing that we now have thirty acres of new orchard and every tree is set with dynamite.

You will probably be amused at my zeal, but $I$ used half sticks of dynamite in making up a rose bed, and also for a hardy border set with peonies and other perennials. Am happy to say the peony plants are now ready to bloom profusely their first season, although, hitherto, $I$ bave failed to bloom them before the second or third year.

We wouldn't undertake to clear ground or set new trees, shade or orchard, without using dynamite, notwithstanding our soil is a beautiful loam, with little stone in it, and runs from five to six feet deep. MRS. JOHN RAWLEY. 


\section{Prominent Nurserymen Describe Successful Methods}

Harrison Brothers, with nurseries at Berlin, Maryland, have 4,000 acres, which contain more than 200,000 trees, and they are among the leading nurserymen of the East. They have prepared a very complete book entitled "How to Grow and Market Fruit," retailing at 50c. a copy, containing valuable information.

They say, "What is stated here is the most practical kind of hard-won knowledge, for it outlines 'how we do it' in fruit-culture."

From the chapter on "Methods of Keeping Moisture":

"Subsoiling with dynamite is a thoroughly practical method, and should be employed on three-fourths of the farms of the East.

"By far the best way to loosen subsoil is with dynamite. This is not generally known, but orchardists will find they can reduce tillage expenses greatly and save much time with it. The exploding of from a sixth to a half pound of the right kind, two or three feet under the surface, loosens and makes fine all the soil. Young trees will make great strides if they are so planted.

"The dynamiting can be done in orchards or about trees of any age. If done rightly, it will accomplish the work without breaking or tearing away any roots, leaving the soil in condition to give the roots twice the feeding-ground they had before and providing perfect drainage and water-storing capacity. The use of dynamite is the secret of success in growing fruit by mulching systems without so much plow and harrow tillage."

From the chapter on "Cultivation":

"It is necessary to break up the subsoil, whether there is hardpan or not. The dynamite method usually is the cheapest at any time, and it is the only way by which the work can be done thoroughly after trees have been planted.

"Dynamite is the thing with which to dig holes for new trees, to break up the whole soil three or four feett deep every few years, and to help renovate old orchards, because it will do these things more cheaply and better than they can be done by any other means. If you have fruit trees, which seem to be standing still and which do not bear, no matter how, big they are, properly explode a charge in the soil around or between them, and the trees will likely get to work. In a bearing orchard, a proper charge midway between trees is always safe and is generally very effective."

From the chapter on "When Trees Will Not Bear":

"Explode three or four charges of dynamite a few feet away from each tree. Mulch the surface with a thick covering of vegetable matter, or by keeping a couple inches of dust under the tree. Feed with commercial fertilizer."

From the chapter on "Grapes":

"Vines are heavy feeders. Their roots extend far out and make a network in the soil. The proper distance to plant will be from six to eight feet apart, although sometimes this can be changed to advantage. Strong varieties. on fertile soil, need more room than small growers on poor soil. Before planting is done, the ground should be worked even more thoroughly and deeply than for a tree. Remember that you are planting something which will last a generation, not a crop to be removed in a season or two. Plow the land, use dynamite to dig the holes, and have a clearance inside the hole of at least twenty inches."

\section{Trees Planted With Red Cross Grow 50\% Better}

\section{Nitagara River Nurseries and FrUit Farm.}

Youngstown, N. Y., November 27, 1911 .

The trees planted April 23, 1910, with dynamite did so nicely that during the spring of I9I I we planted several hundred trees in holes dug with dynamite and in every case the trees so planted grew and made onc-half more growth than trees planted in the usual way.

We think so well of the process that we shall plant all of our trees during the spring of 1912 with dynamite.

On our soil, which is a very hard hardpan, we can dig the holes for one-half the cost of digging with spade. We now feel confident that the shattering of the soil is a great advantage. Last season was the dryest ever known in this section and yet our trees where holes were dug by dynamite kept green and grew right along. I think we will get a better and deeper root system.

We used only one-third of a stick for peach trees and that gave us a fine hole 2 feet deep and a good breadth. We stake our ground out, drive a hole where the stake stood, insert the charge and the work is done in an instant. One man can keep a fair gang busy following up and putting in the trees. 


\section{General Advice on Tree Planting}

\section{Setting Trees with Dynamite to Conserve Moisture}

\section{ARTHUR E. COLE, Prop, High Point Farm and Nursery, Chamblee, Ga.}

Over a large portion of our country is a hardpan of shale or tight clay near the surface. It is a menace to the productiveness of trees and all vegetables which root deeply. The scientific principle involved is the inability of such a subsoil to absorb, retain and give back to growing crops the essential moisture. On such land the water soaking through a thin topsoil fails to penetrate and finds a second drainage on this subsurface, draining off in "Wet Weather Springs" or standing in surface suspense as "Bogs." Land in this physical condition fails of an agricultural dividend. Put in proper physical condition this same land becomes, highly profitable. The way to proceed is by using dynamite. Probably no process of plowing known to agriculture can produce the good results in breaking up a tight subsoil that does this blasting with Du Pont Dynamite.

Planters of clover, and alfalfa realize this. Orchardists have come to accept it as final. Strawberries and all crops requiring a great amount of moisture respond to its use in a way almost unbelievable. Short lived crops like tomatoes and cucumbers will continue to bear through the long season where the hills are shot with cartridges of dynamite. Figs produce a crop the first year after being set where dynamited. The writer can see this from his back door as he writes. This new-found process is the foundation of a new era in agriculture and horticulture.

At the present time many thousands of trees are being set in young orchards all over the United States. Such a boom in apple and pecan planting was never before known. It is a logical answer to an unsupplied demand. The question is, will these orchards endure-will they pay?

In orchard setting, the use of dynamite is advised in practically all soils. The pecan naturally flourishes on the deep, moist, alluvial soil of river and creek bottoms. Nature has put it where it will not suffer from drought in the long, hot, dry summer and autumn through which it must hold and mature its late fruit. We can move it to our grove or back yard and succeed with it by dynamiting the ground.

Watermelons and peaches should be dynamited because they require great moisture, being fruits composed largely of water, but of all fruits demanding an unfailing and continuous supply of moisture the apple and pecan lead. Therefore, it is imperative that we dynamite as an artificial means of conserving the moisture. Unlike all other fruit, the apple grows on the end of a twig of new wood, a twig which bears no more. The apple being a biennial, sets its fruit bud for next year during July and August of this year. So we see this hard condition imposed: a winter apple must make its new growth of wood, hold its foliage, mature its present crop of fruit, and, if it is to produce again next year, the little tender twig bearing an apple must mature a new fruit spur or twig alongside of it to bring forth a healthy fruit bud next year. And all this during a long, hot summer or autumn. The demand for moisture is enormous. 
What if the tree is shallow set? What if the roots trail along close to the dry surface? What if the tree is on a dry ridge or hillside baked by the summer sun? What if on thin land, starved for both fertility and moisture?. The answer may be total failure 0 . partial failure and short lived trees, or a partial crop, or a crop only every other year, or a large per cent. of drops, or defoliated trees. READER! Observe and mark well. Your orchard dividend and its future success is in balance when you set your orchard. Remember you can never set it over the second time. No amount of regrets can retrieve a mistake made in the setting. You will spend much money bringing your orchard to a high standard by the allotted time for it to begin to bear, but no amount of money expended in after years can correct a mistake at planting time. You may have in mind plowing out a deep furrow for your row, but remember that that furrow can never be plowed again, and the root system will be influenced to confine its growth to the small amount of pulverized soil. Holes may be dug, broad and deep, but like a large plant in a small pot, the hard walls of the hole when filled with roots will cramp or turn back or callous. Either of these methods will be found wanting.

The new and eminently successful mode of land preparation for all fruit or ornamental trees and for many field or garden crops, especially in tight, dry soils, is by blasting holes with half cartridge of Red Cross Extra Dynamite or blasting the furrow with a like amount at intervals of 15 to 20 feet. If in a large orchard or a large field, a blasting machine may be used to detonate the charges. If only a few trees are to be set, the blasting should be done with fuse and blasting caps. Let the depth of the holes for setting your cartridges be governed by the state of the soil. Make a hole with auger, sharpened wood dibber, or crowbar well down into the subsoil. Tamp well with moist clay. For the best results, throw out a bushel or more of the clay that has been broken by the shot and fill with some organic matter that will slowly decompose as the years go by, mixing and cutting in well with a sharp shovel or spade. Leaf mold, woods topsoil, fence corner settlings, old bones, scrapings from under an old house or outhouse or any such matter is good. Now the roots can go down and out in an area broken and pulverized for many feet on all sides. The tree will make a rapid and healthy growth and come to bearing earlier and live many years longer. It will produce fruit annually, more fruit, larger fruit and fruit of better color because of the conserved moisture. It will resist drouth. The much talked of "insect resisting tree" is a tree healthy and vigorous enough to overcome their baneful attack.

- The writer set an apple orchard last winter, using Red Cross Dynamite, in an area where woolly aphis is known to abound; but not a single evidence of their presence has been noted.

The winter, spring and summer just past is one of the dryest on record for Georgia. Many trees, in fact a large per cent. of trees, set by the ordinary method have died. But in three orchards set by the writer with dynamite, $100 \%$ are living and doing well. As a neighboring nursery man expressed it, "These trees didn't know it had not rained." 


\section{Wanted Proofs and Got Them}

\section{A subscriber to the "Rural New Yorker" wrote the editor of the paper the following letter:}

\section{Dynamiting for Planting Fruit Trees}

What information can you give as to the use of dynamite for planting fruit trees? I expect to set out quite a few this Spring, and am wondering if it would be the thing to use on my land, which has a shallow topsoil, about 18 inches of gravelly subsoil, underneath which is a very hard, clay hardpan. The dynamite makers claim great things for their product. I would like to hear what others have to say who have used it.

Connecticut.

R. N. Y. - We want actual experience about this if we can get it.

J. W. M.

In an issue of the Rural New Yorker, published two weeks later, the following letters from subscribers were published in answer to $\mathrm{J}$. W. M.'s inquiry:

\section{Dynamiting in Tree Planting}

In answer to J. W. M., page 126, in a block of seven-year-old apple trees, about a dozen failed to make a good growth. and one of them died when four years old. Replanting, the tree failed to live througin the Sunimer. The soil is Hagerstown shale loam, and we found the shale very near the surface in this place. Before planting the third time we used about one-third stick of dynamite (say three ounces), making the hole with a bar and putting the charge about two feet under surface. The result was a mass of fine shale of about a cubic yard in extent. The tree was planted and grew and made a good growth, although the season was very dry. J. W. M. would have to get well into that hardpan with his dynamite and use more of it, say one-half pound. I think the cost would be justified in the better drainage secured, as unbroken hardpan within two feet of the surface would hardly be an ideal condition for an apple orchard.
Pennsylvania.

Pennsylvania.

I planted 150 trees with dynamite with the best success; they make a much quicker growth. They will grow in two years as much as the old way will in three years. If the soil is very hard digging, it will be found much cheaper.

Massachusetts. $\quad$ C. M. O.

J. W. M., Connecticut, wants actual experience in dynamiting holes for fruit trees. I tried that last Spring for over 100 peach trees in heavy clay subsoil on land that would raise scarcely more than 20 bushels of corn to the acre. I used an iron rock drill and drilled down about three feet, and used one-third stick 40 per cent. dynamite. The dynamite fuse and caps cost about four cents per tree, which I think is a very cheap way of digging the holes, as all I did after I shot the holes was to shovel out a few shovelfuls and set the tree. As last season was very dry with us the trees made good growth; they were headed back to about 18 inches from the ground and about five-eighths inch in diameter when set, and now they will average seven feet tall and most of them will average two inches in diameter, and some larger than that. This ground was in corn the season before, and the patch was set in straw and tended up to September. One of my neighbors set peach trees last Spring in the spade-dug system and those trees made very little growth. We have a man near New Albany, Ind., who runs a commercial orchard system; he has been trying it 12 years and I heard him say he would set no trees without dynamiting, thinking it paid largely. From what experience I have had and seen from others $I$ would certainly try dyna. mite, for it certainly tears up the subsoil and gives those roots a chance to go down to moisture, and dry as the season was, I never lost a single tree out of 104 , which I think is very good.

R. F. T. BORDEN.

In the Spring of 1911 I set 52 apple trees in filling in an old orchard where the trees had died. First tried one-fourth pound, but found that too heavy a charge as it made too large 2 hole; then used one-sixth pound charge. First I bored in about 12 to 15 inches, pushed the stick clear to the bottom, tamped it well and let it go. We could set a tree in the hole easily in five minutes, one holding the tree and treading in the dirt as the other shoveled. Not having enough dynamite, two holes were dug with shovel. Result, one of those trees died and only one of those set in holes that were dynamited. The soil is a sandy loam underlaid by sand rock about three feet below the surface. All trees were heavily mulched with straw early in the season before the drought began. Some of the trees made a new growth of more than two feet on each limb, while the tree set in the dug hole made a growth of three to six inches. An observation of the trees is proof conclusive that it paid to use the dynamite. The trees set were two years old.

We are using dynamite bere for setting grape roots, and it is a good thing for clay or

H. hardpan; do not think that it would do any good in mellow or gravel soil. It would be necessary to get the dynamite down in the clay and to tamp the ground down hard around the dynamite before firing the fuse; the explosion then would loosen the ground in all directions, and would enable the root system to extend more quickly.

Hammondsport, N. Y.

J. W.

Last Spring in preparing for planting fruit trees I decided to use dynamite, which was so entirely successful I shall give you my method. For making the holes 1 used a heavy iron bar, sinking it from 20 to 24 inches, using one-quarter stick dynamite, pulverized, then after placing cap and fuse tamped wet earth into hole. This would loosen the ground four or five feet deep and about four feet on each side, in ordinary freestone soil with heavy yellow clay subsoil. My trees made larger growth last year, where other trees in the neighborhood which were dug in made very small growth or died from the dry weather. Care should be taken to pack soil well around trees when put in. Cost of material for shooting holes was five cents each, not including labor.

Secbert, W. Va.

W. M. I.

Du PoNr Edrtor's Notz.-Neither the inquirer nor endorsers were known to us. 

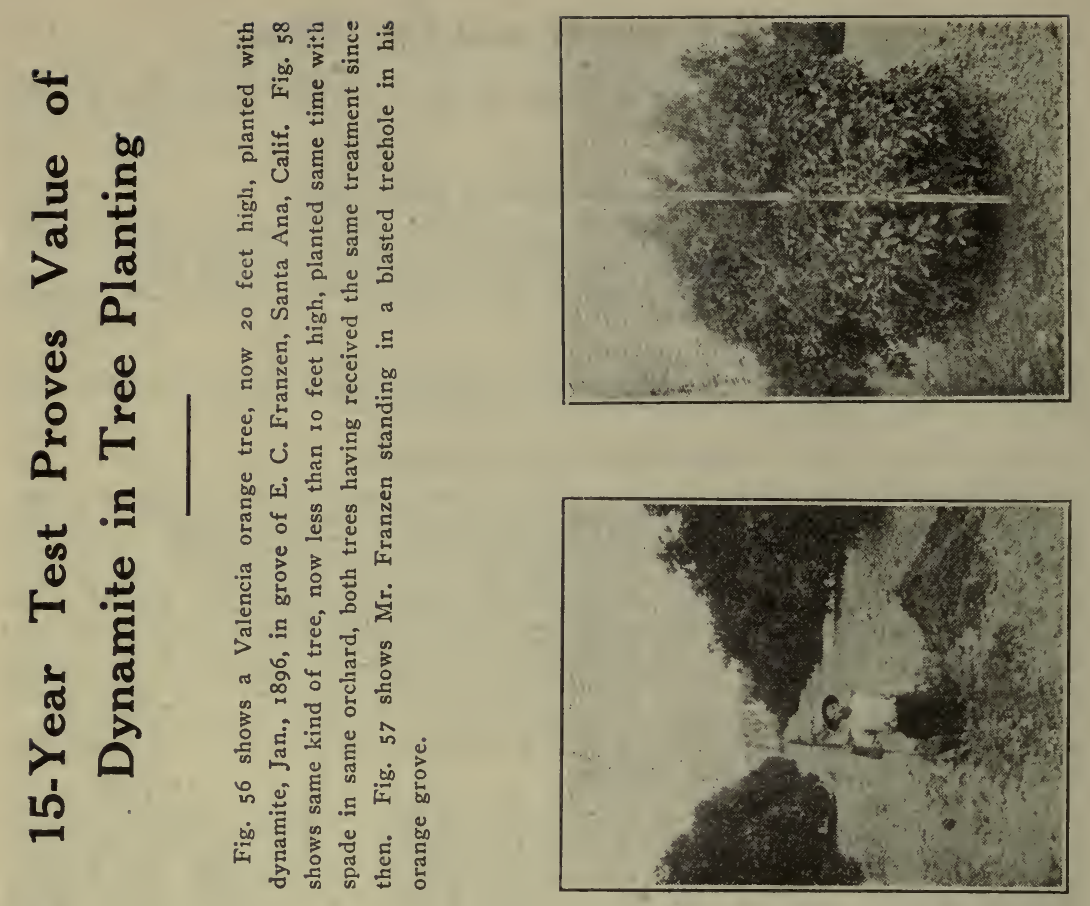

in

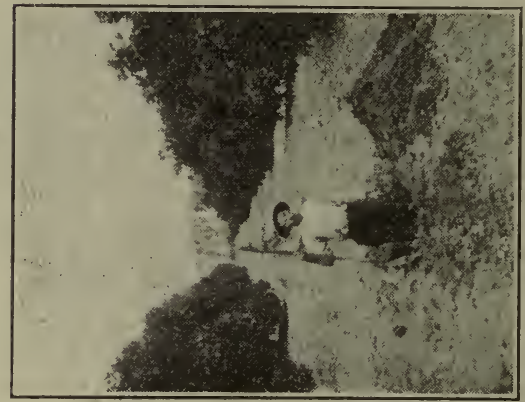

in

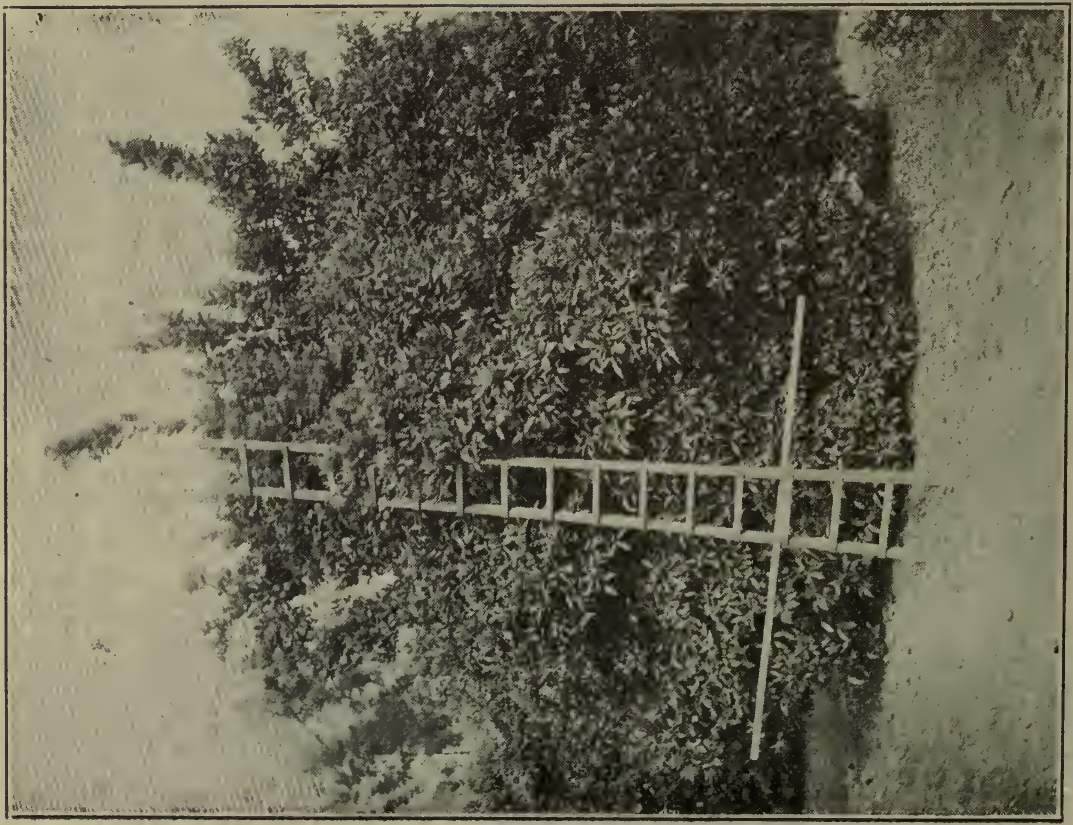

نำ 


\section{The Proper Way to Set a Tree}

\section{Some Advice on Tree Planting From the Booklet of a Prominent Nurseryman}

A. Good fertile topsoil must be used about the roots. If the tree is to be planted in impoverished ground, good soil should be provided for it.

B. Plant a tree just as deeply as it stood in the nursery row. This depth is very easily determined by the dirt line always shown at the bottom of the trunk. Failure to plant in accordance with this rule probably results in the loss of more trees than any other cause.

C. Before planting cut off all the broken or bruised parts of roots.

D. Be sure to press earth firmly about the roots, especially about the crown, so that every particle of the roots will be embedded in compacted soil.

E. A tamping stick may be used to work the soil firmly about the roots. With small trees and plants the dirt will settle firmly, if the plant is gently lifted up and down, when the hole is half filled, so that the dirt will work its way between the roots. Just before filling in all the dirt press it firmly. Be sure that the dirt is well compacted, excepting three or four inches at the top of the hole, which should be loosened by occasional cultivation.

F. If buds have begun to swell at time of planting or if the ground is dry, watering when the hole has been three-quarters filled will not only moisten the roots, but help settle the soil firmly about them. Should drought ensue afterwards, occasional watering will be necessary until the tree becomes established; watering is, however, frequently overdone and death from this cause occurs to trees and plants almost as frequently as from neglect to water.

G. Trim broken or bruised branches, also two-thirds of the previous year's growth; because the roots in their disturbed condition cannot at the outset nourish as large a top growth as before they were disturbed by moving.

$\mathrm{H}$. It is often best not to trim the leader or central stem, as a forked tree may result. Hardwood trees, like the oak and beech especially, should not have their central leader trimmed.

I. If the tree is large or in an especially exposed place where winds may loosen it, support it with wires and provide some protection where the wires come in contact with the tree trunk. A piece of burlap with a few sticks are useful to prevent the wires chafing the tree where they come in contact with it.

J. After planting, it is better to leave a cultivated area about the tree than to sod close to it. This cultivated area should be from three to five feet in diameter.

$\mathrm{K}$. Fertilizer, in the form of stable manure or compost, may be used, but should not come in direct contact with the roots. A mulch applied after the planting is usually the best way to supply this fertilizer, as it then also acts to conserve the moisture. 

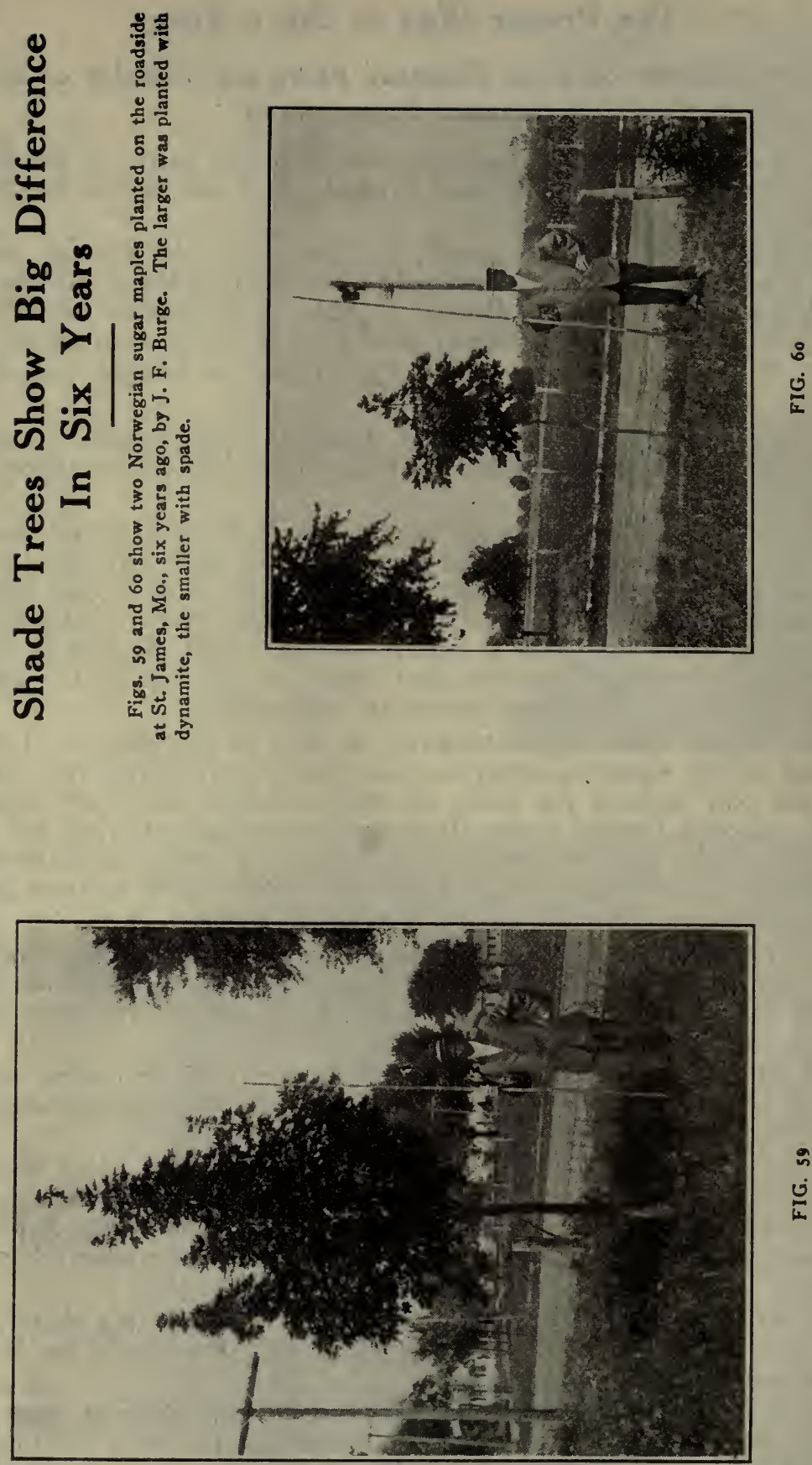

in 


\section{Blasting California Hardpan for Trees}

Sacramrato, Caz., Jan. 2 i.

Edstor Western Empire:-I have been reading several articles on plowing with dynamite, also the breaking up of hardpan by the same mcans, and would like your advice on the subject. I have ten acres underlaid with hardpan at a depth ranging from eighteen inches to four feet which is from one to nine inclies in thickness. I am desirous of planting fruit trees and would like to break up the hardpan for each tree, but find that the cost of using powder, and labor involved, is a little beyond my means. I' have seen practical tests made and examined the ground after blasting, and find it would take considerable dynamite to break the hardpan in its thickest part, also it is impossible to tell whether the hardpan is broke thoroughly or not when covered with two or three feet of soil. I wish to know if I get as good results by boring holes with an ordinary hand-power well-drilling rig. By boring a six to twelve-inch hole, five or six feet deep, it seems to me it would give as good results, and be more certain of breaking through the hardpan than dynamite. I have helped to drill several wells, and know it would only take two men a short time to go a few feet deep. If you will please advise me in the matter by letter, or in an early issue of the Western Empire, I shall be very much obliged to you.

$$
\text { - Yours truly, } \text { T. }
$$

(The editor replied as follows:)

The writer has done a very considerable amount of blasting for trees and vines, and from results fully recognizes the value of a judicious use of dvnamite for breaking hardpan.

We would not plant any hardpan land to trees without blasting every tree hole. The expense of this is not to be considered in comparison with the benefits that will come from good tree growths and profitable bearing orchards, as a result of breaking the hardpan, to give the trees deep root systems.

We think your proposition to drill well holes through the hardpan is hardly feasible. In practice, it will cost to drill the holes, then fill them with earth, then dig the tree holes, as much, or nearly so, as the cost of blasting. And after such well holes are drilled, the main object of having the largest area of ground prepared properly for the planting is not accomplished. Even if this drilling could be done at much less cost, we would not resort to it, for results in the life of the orchard would be a perpetual tax on the mistaken economy.

This is what we do:

First lay out the orchard, having whitewashed pegs where the trees are to stand. Then, instead of using the ordinarv tree planting boards, make one at least ten feet long. out of a one hy four, boring inch holes in the ends and midway between them making a notch.

In using this implement, place this notch over the tree peg, and set two pegs through the end holes and withdraw the tree peg. After the holes are dug the board is placed over the end pegs, and the notches in the board indicate the exact position where the tree should be placed.

Now dig an ample tree hole to the hardpan, and drill into it according to its thickness. From your description of the hardpan this will be an easy matter.

Much judgment is to be exercised in determining the kind of powder to use and the amount. The object to be obtained is a thorough breaking and cracking of the hardpan, and the wider the area of this action the more effective. Hence a slower action of the charge is often better than a more violent explosion. Good judgment and some experience will soon enable one to determine the depth of the drill holes, and the amounts of the powder to use.

Dynamite is made of different strengths and longer or shorter sticks can be used. Where the hardpan is a thin layer, and more or less seamed, it may be better to dig a small hole to the hardpan for the drilling rather than the larger hole as suggested.

Where hardpan is five or six feet deep, or where the subsoil is of a close, tenacious nature, it is a wise practice to make a deep hole with a bar or small earth auger at the point where the tree peg was removed, and explode a charge heavy enough to thoroughly shatter the subsoil.

\section{California Hardpan Conquered}

\section{Dinuba, Cal., October 7, 1911.}

The trees planted last spring, for which the land had been dynamited, are doing exceptionally well, in fact, much better than I expected. The demonstration you gave convinced me that the value of Du Pont explosives cannot be overestimated. My land had a heavy stratum of hardpan at an average depth of one and one-half feet, and under this hardpan was a very good subirrigated subsoil. After blasting the holes and planting the trees this spring they have not had one drop of water, either through irrigation or rainfall, and now they are in very fine condition. Z. M. DICKEY, Manager.

\section{Lemon Grove Improved}

Corona, Cal., October 14, 1911.

I am working upon the strip of orchard which was shot last fall and I find a marked improvement in the appearance of the lemon trees.

It is my intention to continue this work of blasting until I have treated all portions of our orchard where the conditions of the trees indicate the existence of a hard formation under them. W. C. McCULLY, Mgr. El Cerrito Rancho. 


\section{Success With California Hardpan}

\section{ARLINGTON HEIGHTS FRUIT COMPANY. \\ Riverside, Cal., December 16, 1911.}

\section{Gentlemen :}

Some ten years ago we began shooting in our orchards where hardpan conditions existed. You will appreciate that in most districts in California the hardpan exists to a greater or less extent. With us it is not found to any great extent, but rather in deposits here and there. Where found, whether near the surface or deeper down, it is a great detriment to the proper and rapid development of the trees, and their profitable production when grown.

For this reason we determined upon shattering the hardpan, and at first it was an expensive matter, for we used the dynamite and then, in order to make a very thorough job, blew the hole afterwards with from one-half to a full keg of black powder. At times we shattered the ground for a radius of from ten to twelve feet and blew the soil and hardpan out of the immediate vicinity of the charge. The hole, thus made, we filled with manure, using a considerable quantity. We were satisfied very soon after the first work was done some ten years ago that whatever the cost, it was well worth the doing.

We have continued doing this work and at all times have been well repaid for the expense. Our success here with this work led us to shoot the ground where hardpan conditions showed up when planting the orchard, and our success with that has led us to shoot the soil wherever it could not be easily penetrated by the root system of the young trees.

Fifteen cents spent in this way in heavy soil, prior to planting of a young orchard and a larger sum used wherever hardpan conditions exist, will many times over repay the cost whether in an old grove or in the planting of a young grove.

In an old grove it opens the soil and permits the water to go in in larger quantities, much larger quantities. It makes the root system of the trees penetrate to greater distances from the trees and to greater depths. In the young orchards it gives greater field for the young trees to spread out their feelers. The water will penetrate and distribute itself much more freely and much more effectively and in much greater quantities.

I do not hesitate in advising always, everywhere, to examine the subsoil conditions in any area about to be planted, in order to determine what conditions are to be met and how to meet them. As a general thing, hardpan is not a detriment, it is easily shattered and the conditions easily controlled under our present methods of agricultural procedure. Do not hesitate to use powderDupont's-as you can find nothing better.

Yours truly,

JAMES MILLS, Superintendent.

\section{French Prunes Do Well in Blasted Holes}

Gentlemen :

$$
\text { Saratoga, Cal., Sept. 17, } 1911 .
$$

My experience with dynamite in an orchard has been confined to removing diseased and dead trees and opening holes to plant new trees. I have found this method much more rapid and hence much cheaper than by digging. It also leaves the soil in ideal condition for planting the new tree.

There was a block of five trees that had been replanted each year for four years, without getting one to grow. Last fall the holes were dug as usual and in the bottom of each hole we exploded a stick of Hercules No. 2 (40\%) Dynamite. The trees (French prune) that were planted in these holes last winter are the strongest testimonials to the value of this process that could be offered, sending out new shoots six and eight feet long. In planting young trees in virgin soil the same results have followed, as it so thoroughly loosens up the hard ground that the young roots have every opportunity to start, causing the tree to make a vigorous growth the first year, which is most essential to the value of the tree.

Yours truly,

GUY U. SMITH,

State Assemblyman, 36th District. 


\section{Plants Six Hundred Acres for $\$ 6.00$ an Acre}

\section{Woodlake, Cal., June 30, 1911.}

During the past three years we have set out six hundred acres of lemon and orange trees and in every instance have used a stick of your dynamite (Red Cross) in the hole where the tree was planted. The trees are all healthy and doing fine. There is a very marked difference between the trees that were set in this manner and those not dynamited.

In using this dynamite we bore a hole three feet with a two inch auger at a cost of about two cents per hole, which, with the cost of the dynamite and the labor in exploding same for ninety holes per acre, is about $\$ 6.00$ per acre. There is no other manner by which the ground can be prepared so well for planting at this cost. WOODLAKE ORCHARD CO., By G. F. Stevenson.

\section{Planting Walnut Trees in California}

I planted 100 walnut trees this year with explosives and they have already grown larger than those I planted the year before where I did not use any powder in digging the holes. The powder beats anything I ever saw for making the trees grow fast. My land is mixed with sand and it is mostly black loam. I drilled my holes seven feet deep and then put in a half stick of Hercules No. 2, 40\% and a handful of Champion and tamped the holes tight. After the explosion you could shove down a stick to a depth of ten feet, and I do not figure my cost over $20 \mathrm{c}$. per hole. It would cost many times as much to dig them by hand and then the holes would not be half as good as those dug with powder. I have been using powder for many years, but never before for tree planting, but hereafter all my trees will be planted with powder, as there is nothing like it.

JAMES GRUBB, Tudor, Sutter County, Cal.

\section{Gets World's Record Breakers in Dry Farming Section}

Goodpasture, Colo., December 16, 1911.

Many years ago I saw a farmer using this on a portion of irrigated ground that he could not dig with a spade, and these few trees did much better than where the holes were dug. The thought occurred to me if this was good for irrigated ground, it ought to apply to non-irrigated, so I thought I would give it a test. I dug my tree holes 2 feet in diameter and 2 feet deep, drove a drill in the bottom of this hole about 24 inches (and by tapping the sides of this drill, it can be easily pulled out). I used about two-thirds of a stick of dynamite which opened the ground many feet.

The cost of dynamite for these holes was about 10 cents each, and the land is of such a nature that it would have cost ten times that much to dig these holes by hand. I also planted a few trees, in spade-dug holes. These trees have died, while the fruit from the trees planted in dynamite-dug holes won a world's prize.

My first planting of trees by this method of dynamiting and thorough cultivating was 180 apple trees, set in the spring of 1907, and I have only lost one and that was killed by the rabbits. Have planted many trees since by this method with good results. Trecs begin to bear the second year and look as well as irrigated ones. They are the world's record breakers.

LEE R. ROPER.

\section{"Never Again" for the Spade}

Crozet, VA., November 7, 1911.

I am using your Red Cross Dynamite every day now; and have bought 250 pounds to plant 1,000 trees, and am getting along fine, and find it $\mathrm{O}$. K. I shall never dig another hole for trees except with dynamite.

Several of my neighbors came around and I showed them the work. Then they bought dynamite to plant their trees with.

S. K. GARRISON, Grower of Apples, Peaches, Pears, Strawberries. 


\section{Proved Results in Cultivating and Regenerating Orchards:}

1. Young spade-set trees can be forwarded in development at least a year by dynamite blasting between the rows.

2. Old, failing trees can be restored to ample productiveness by blasting between the rows.

3. Fungus diseases can be eliminated by blasting under affected trees, or blowing out those killed by fungus, and planting new trees in their places.

\section{Cultivate Spade-set Trees With Dynamite}

We frequently receive letters from orchardists stating that they had planted trees in their orchards a year, two years or three years ago which are not doing well because of hardpan conditions beneath the surface soil or because of compacted soil or insufficient moisture storage capacity of soil. These orchardists express the keenest regret at having learned about tree planting with dynamite after their orchards had been planted. They tell us they believe their trees would be in a much better condition had they been planted by this method.

If their trees are alive, there is no occasion for repining. The subsoil in which the trees are planted can still be broken up by subsoil blasting between the trees. This rejuvenation work will give the trees the same favorable opportunity for growth and development that they would have had had they been planted in holes prepared by dynamite blasting in the first place.

Millions of fruit, shade and ornamental trees are standing in the orchards, parks, yards and along highways in this country. Many of them are very valuable because of the fruit they are capable of producing. Others are highly prized by their owners because they serve to ornament and shade residence properties or parks; others add greatly to the appearance of streets.

But many of these trees are in an unhealthy condition. This may be due to various causes. An investigation will show that soil conditions are at fault as often as any other cause. Many of these soil conditions may be remedied by subsoil blasting between the trees. If the soil in which the tree is planted is compacted so that it is difficult for the roots to make healthy growth into the deep subsoil, or if the soil is not sufficiently porous to permit of the absorption and storage of moisture, blasting with dynamite will prove an effective remedy.

In every part of the United States will be found trees in parks and along public highways showing signs of deterioration. Sometimes these conditions are due to the fact that the trees are planted in poor soil; sometimes because they are in soil underlaid with hardpan or compact subsoil; sometimes because their roots grow out under asphalt, cement or flag pavements which prevent them from obtaining the benefit of rainfall. In any of these cases the use of dynamite will improve the health of the tree.

The Park Commissioners at St. Louis and Joplin, Mo., and Los Angeles and San Diego, Cal., have recently used dynamite for these purposes with excellent results. In St. Louis 200 trees were planted at a cost less than the work could have been done by labor alone.

Mr. Kieth, a Park Commissioner of Joplin, Mo., is a member of the National Park Association and intends making a report to the Association of the results obtained in his city. His experience in planting walnut and black locust trees was such that he says he will always plant trees with Du Pont dynamite hereafter.

\section{Rejuvenation of Trees Within City Limits}

Every old town has many trees along the streets that are failing, from one cause or another, but mostly from root cutting on streets where sidewalks have been laid, cutting off their former supply of nourishment. In this contracted space the tree soon exhausts what little fertility is within easy reach.

Many an old dying tree have I resuscitated by a half dozen small charges of dynamite below the root system, often filling the hole after the charge is in with some fertilizer which will be scattered through the soil close by the roots, giving them the immediate effect.

$I$ use this same method in orchard dynamiting and it works wonders. Often the effect can be seen in ten days after treatment.

M. J. WALTERS, Elyria, Ohio. 


\section{0-Year-Old Orchard Successfully Rejuvenated}

Stonington, Aug. 23, 1911.

Last Spring I used your dynamite to try to improve an old apple orchard, planted over 60 years ago, which has borne little or nothing for the past four years.

The trees were planted 30 feet apart, and had been badly neglected and untrimmed.

I used a half a stick of dynamite between every tree last April, and have been much gratified at the result.

The entire orchard is loaded with apples, and their weight has broken down one tree, and broken limbs of many others.

I think the apples are much larger than usual.

I have also used dynamite in blasting out rocks, with very good results, and am intending to use it more extensively another year.

Very truly yours,

EUGENE P. EDWARDS.

\section{Saves Dying Orchard by Blasting}

Chezryale, VA., February 13 , 1912.

I noted on one or two occasions articles appearing in current magazines and papers on the use of dynamite in breaking up subsoil and cultivating in general, especially in orchards. I set out a small orchard a few years ago with rather unsatisfactory results, owing to the fact that there was a hardpan that ran in this section of the country under the topsoil at the depth of two or three feet, which in rainy weather allows no moisture to penetrate, making the ground soggy for the time being; and then during a dry spell, with no moisture obtainable from beneath the hardpan, it is only a matter of a short time before the ground is as dry as a bone.

On reading the above mentioned articles I immediately made up my mind to give dynamite a trial, for the trees were practically at a standstill for the past three years and I knew it could do not harm, and I must say that I am more than elated over the results. Where I replanted trees I had an opportunity to place a small charge to loosen the topsoil down to the hardpan, and after cleaning out the same I drilled through the hardpan and broke that up nicely with another small charge. The trees planted in this manner are running away from the rest, and at the same time those trees that I simply cultivated with dynamite have shown marked improvement over those that were simply worked the old way. Although I have had only one season to observe these results, I really expect better results from now on.

I may add that the time and labor saved is by no means a sinall item. By using dynamite, I simply had to ram the bar down about two feet, place a small charge, which cost less than two cents, and was sufficiently strong enough to puff the ground up and around a reasonable distance. With such gratifying results it makes a fellow feel bad when he thinks of the labor and time spent the past three years working around trees the old way, and I assure you from now on it will be dynamite for mine.

Very truly yours,

PAUL C. BISCHOFF.

\section{From a Professor of Horticulture}

Bozeman, Mont., Oct. 3, 1911.

I have been very much interested in the work which you are carrying on to demonstrate the value of dynamite upon the farm, but I am especially interested in the use of this material in planting trees, both as a means of digging the holes and as a means of shaking up the subsoil.

It has been intimated by some that the fruit trees in some of our irrigated sections are shallow rooted, and it is no doubt true. Two conditions are met with in arid sections, which I believe do induce fruit trees to root shallow. One is a hard subsoil, through which the tree roots are unable to force their way. This layer of subsoil is often thin and could easily be shaken up with dynamite. Once the roots of the young trees are through this soil, they would find conditions for growth good below this hard layer, commonly referred to as hardpan.

Another condition, which is just as frequently responsible, I believe, is a dry subsoil which does not invite the growth of roots in that direction. In these arid regions many of our young orchards are planted upon raw land. The subsoil is naturally very dry; and, if the soil is rather fine, it may be several years before the irrigated water applied will reach the depth to which tree roots normally go. But until the moisture is there, the roots will seek the surface soil where the moisture supply is plentiful. And when once the tree has established this shallow system of roots, it does not change.

The use of dynamite in planting would, I am sure, break up the subsoil and allow the irrigation water applied the first season to rapidly settle to the lower soil and attract the roots of the young trees in that direction. The roots well down in the soil are away from fluctuating temperature and moisture conditions and are better able to serve the tree.

O. B. WHIPPLE, Horticulturist, Montana Agricultural College. 


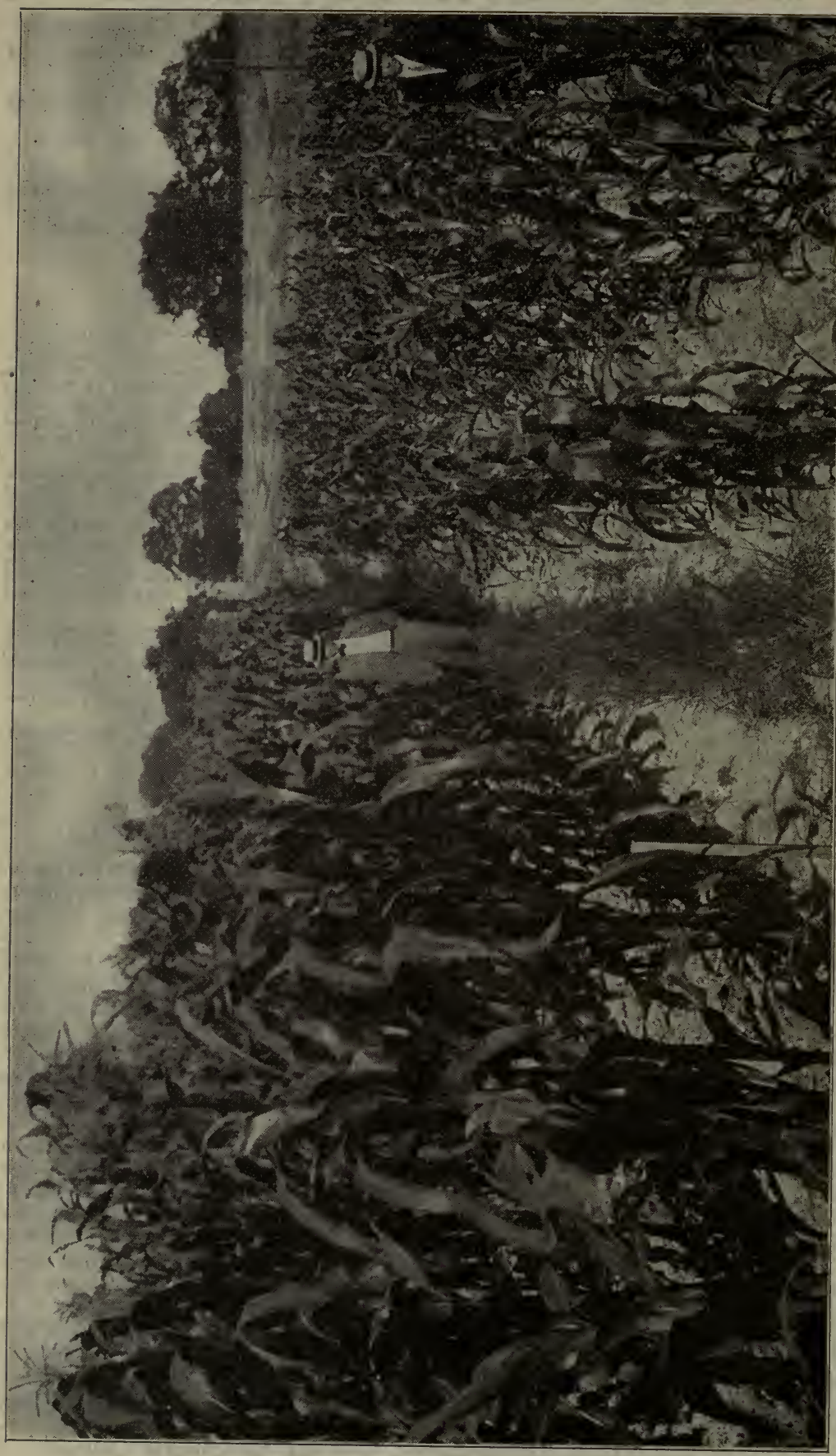

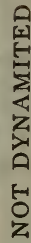

봉

z

ن

3

品

Z

뜽

은

竞

5

ธิ.

ن

ڤ

:

릉

ช

(돈

(x)

选

z

艺

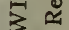

0

20 


\section{Deep Plowing or Subsoiling With Red Cross Dynamite Increases All Crops}

The value of Red Cross Dynamite in the orchard has been proved beyond question.

Let us now consider its value in the production of the vegetables and grains that constitute our chief farm products.

Of course a tree is merely a plant or form of vegetation and the process of soil preparation which will benefit an apple tree will benefit a corn stalk, or a head of cabbage, or a tomato plant, or any other form of vegetation which draws its sustenance from the soil through its roots. With the exception that different plants feed upon different plant foods, the principles of their growth and life are the same in all forms of vegetation.

But we are not obliged to go by theory or opinion. In the following pages we prove by actual photographs and incontrovertible testimony that deep plowing with Red Cross Dynamite increases the growth and fruition of corn, tomatoes, beans, grapes and watermelons, oats, alfalfa, flowers and cotton.

The almost universal condition of farm land throughout this country is that it will not grow good crops unless extensively fertilized, deeply plowed and the crops rotated carefully.

In spite of all these efforts to keep the topsoil rich and productive, the average yield per acre of all standard crops is steadily decreasing.

For generations and for centuries the top layer of our soil has been cultivated to a plow depth of four to eight inches. The same soil has been turned over, year after year, and gradually robbed of its natural, original fertility.

Deep plowing is, in most cases, the remedy for soil detcrioration. When done with a subsoil plow to a depth of sixteen to eighteen inches, there is a noticeable increase in yields. When done with Red Cross Dynamite to a depth of five to six feet there is a phenomenal increase in yields.

\section{Why Deep Plowing Increases Fertility}

The reason why deep tillage or subsoil plowing is desirable is that all the soil below the bottom of the ordinary plow cut, in other words everything below six to eight inches, is still in its primeval condition. It has never been disturbed. Chemical analyses of soils down to a depth of twenty feet show that on the average acre there are tons of plant foods which become available only when roots can penetrate to them, or when ascending moisture brings them up to the roots that cannot get down.

Alfalfa and other deep rooted plants are called "soil makers" because they penetrate this compact soil, introduce humus and provide a passageway for the descent and ascent of water which carries with it the soluble, fertilizing elements, but many subsoils are so hard that it is practically impossible for any one plant to penetrate them. 


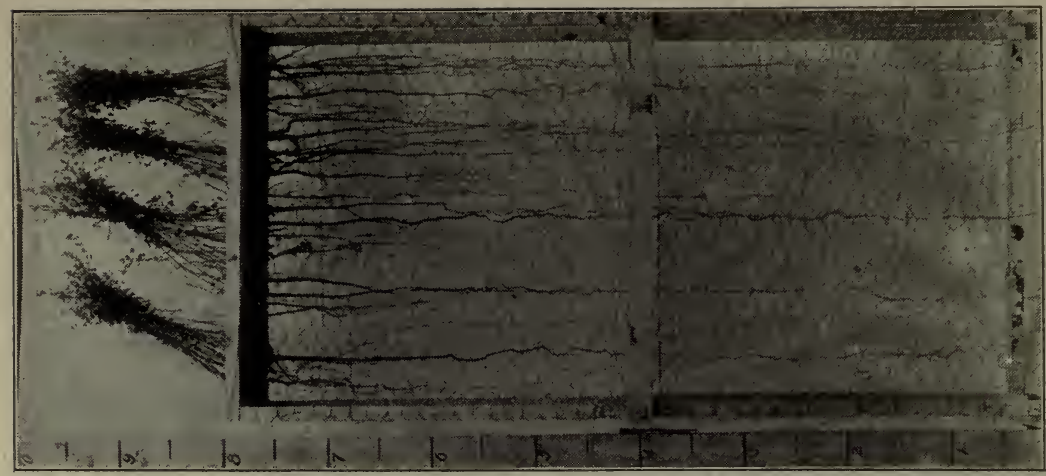

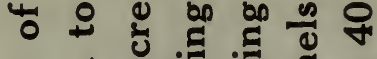

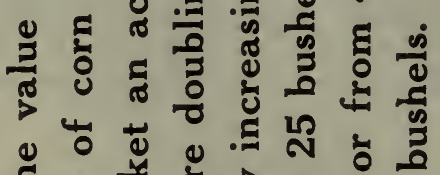

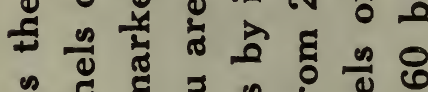

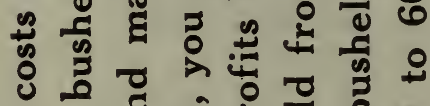

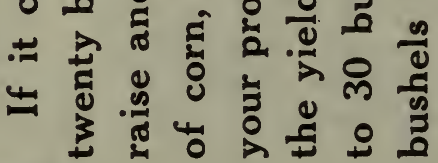

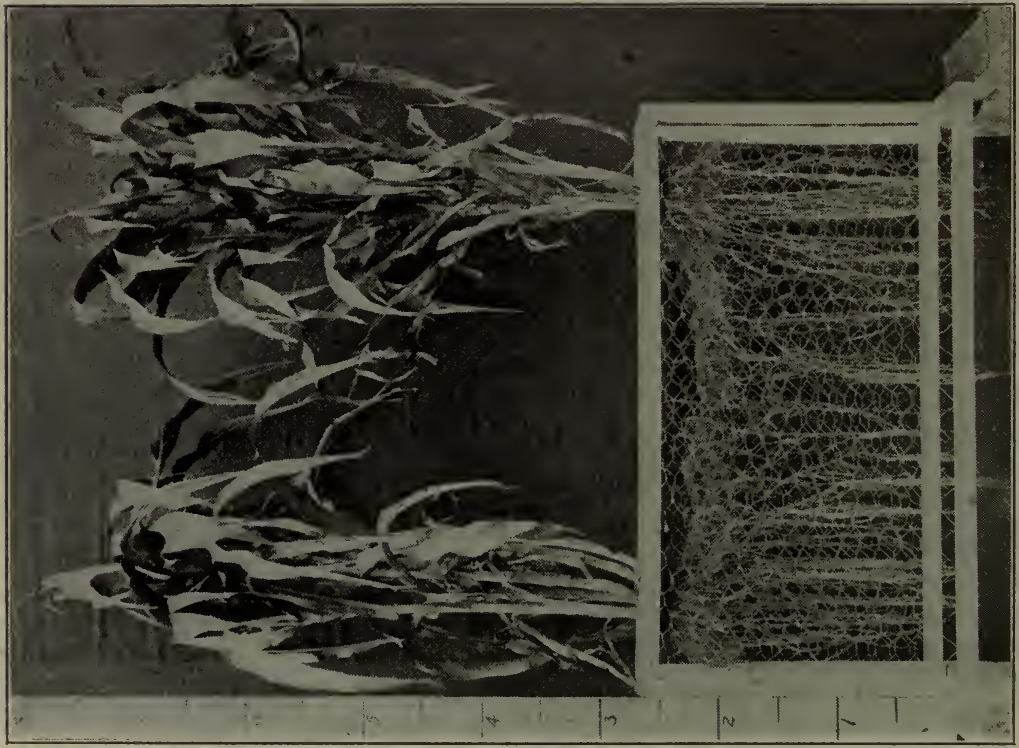


Even when this is possible there is no use in putting such a burden on the plant, because whatever vitality is expended in making its own home beneath the surface is subtracted from the vitality of the plant above the surface. In other words, the plant that has to fight for its life beneath the soil has little energy left for fruition.

If we make root growth easy and, quick by breaking up the subsoil, then we make the fertilizing elements of the subsoil immediately available and save the energy of the plant for fruition. We also create in the subsoil a porous condition favorable to the storage of water at a depth that will not keep the soil cold, and yet near enough to the roots to feed them through capillary attraction. Subsoiling also introduces air into the soil, and it is just as necessary for the roots of a plant to have air as it is for a human being to have air.

Now it is obvious that the passage of air and moisture through the soil, the growth of roots and the resulting deposit of humus, all tend to keep the soil open, hence if it is once thoroughly shattered with Red Cross Dynamite to a depth of five or six feet and the principles of crop rotation are followed thereafter, it is safe to say that that subsoil will never again get back into its primeval compact condition. Whether or not it remains as open as immediately after blasting, depends on the continuity of cropping and the proper rotation of the crops.

The effect of subsoiling virtually is to change a farm from a sixinch layer of topsoil to a six-foot layer. The only element of fertility lacking in the lower five and a half feet is humus and that will be increased by each year's deep rooting crops. The significance of this conclusion must be appreciated by any careful agriculturist, because it means a tremendous increase in available fertility and a practical means of insurance against drouth.

\section{Extracts from United States Government Bulletins:}

The advantages of removing water downward through the soil instead of over the surface may be briefly stated as follows:

"The surface soil is retained entire instead of the finest and most fertile parts being carried off with every considerable rainfall.

Any plant food in manure or other fertilizer deposited upon the soil is carried into it with the water as it percolates downward from the surface, and so becomes thoroughly incorporated with the soil.

Rain water as it passes through the soil serves a most useful purpose by dissolving and preparing crude soil material for the nutrition of plants.

The soil having been well prepared, is at all times during the growing season in readiness for the growth of plants, such growth not being hindered by stagnant water or saturation.

The frost goes out earlier in spring so that the planting season opens one or two weeks sooner than in the case of poorly drained soils.

Where stiff clays are found, the soil is made more porous, open and friable, and roots penetrate more deeply than they do with surface-drained soils. 


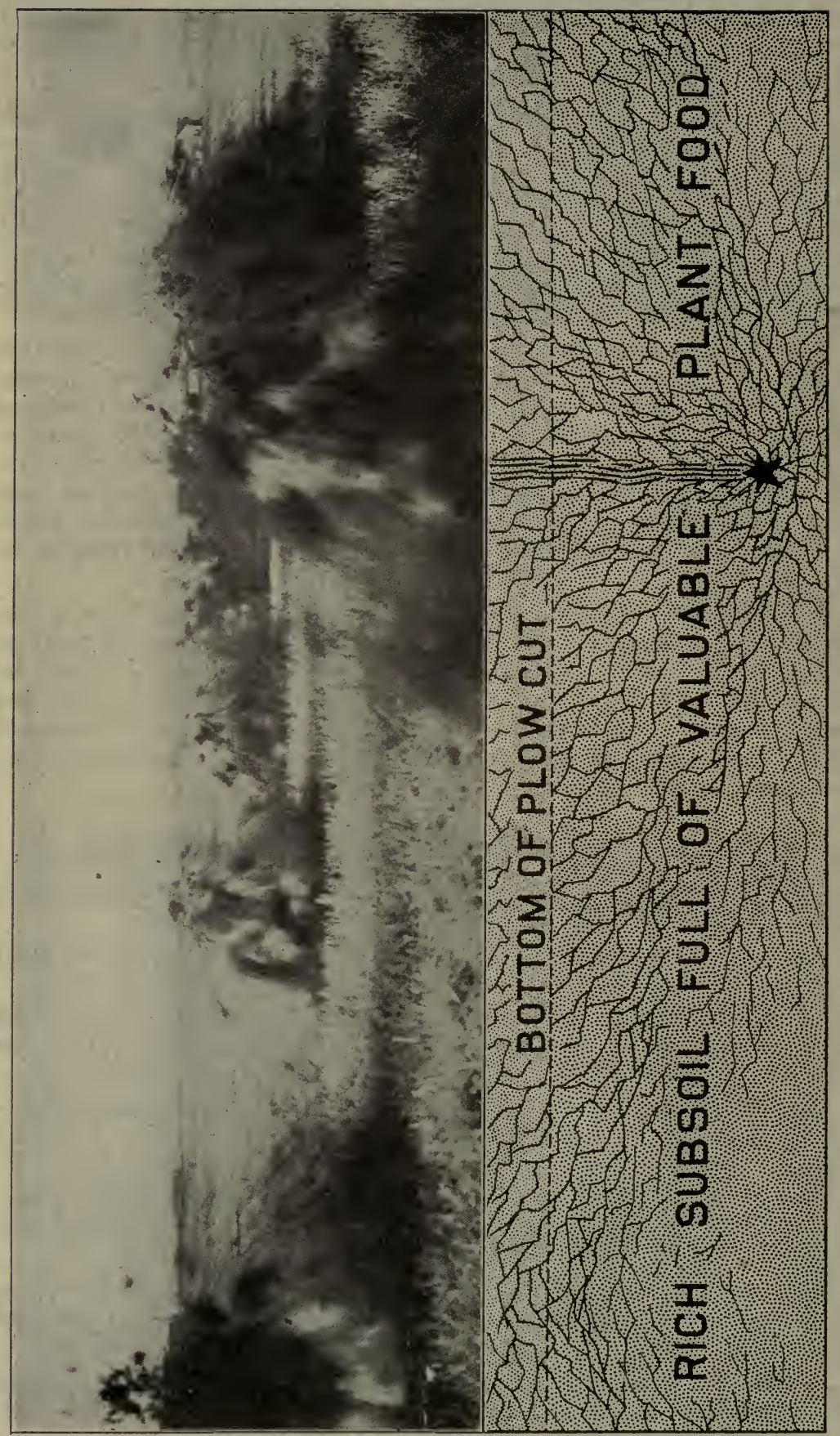

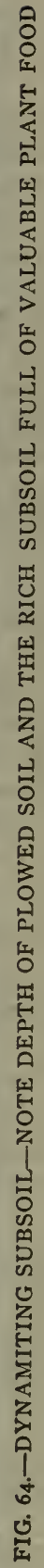


The effects of drouth are diminished owing to the large and deepened soil bed and the more favorable condition of the surface for preventing excessive evaporation of moisture.

It aids in making new soil out of the unprepared elements since it permits a free entrance of air and amtospheric heat, which disintegrates soil material hitherto unavailable for use of plants."

\section{Depth of Root Penetration}

Much misapprehension exists among agriculturists regarding the depth to which roots penetrate the soil. It is a general belief that the roots of cultivated crops do not reach to a greater depth than one or two feet.

Corn roots have been found to penetrate four feet deep and to fully occupy the soil to that depth. On drier and deeper soils they went as deep as eight feet. Roots of small grains, such as wheat, oats and barley, penetrated the soil from four to eight feet and even ten feet in depth. Perennial grasses have been found to go to a depth of four feet the first year and five and a half feet the next year, and they probably go considerably deeper during succeeding years.

Other crops have gone to the following depths: Potatoes, three feet; sugar beets, four feet; alfalfa, thirty to fifty feet. The buffalo berry penetrated the soil to the depth of fifty feet in Nebraska. In California, grape vines went down twenty-two feet; flagwort more than ten feet; goose foot, eleven feet, and hop plant, eight to ten feet.

Most of the above results were obtained in humid or sub-humid regions. Soils and climate differ in such a way as to favor a somewhat deeper root penetration in arid regions, hence it is natural to expect to find roots at even greater depths than the above.

The conditions which encourage deeper rooting are drainage, limited supply of moisture and a soil porous and fertile to a great depth. Deep, early cultivation also forces roots to seek the lower depths. Deep rooted plants are much more drouth resistant, due to the lower water supply during periods of drouth. They also have a larger feeding area, and the fertility of the soil is not depleted so quickly.

\section{Subsoiling With Red Cross Dynamite}

This is the ideal method for breaking up compact subsoil whether this compactness is due to plow sole or natural hardpan, because it breaks up the compact subsoil without throwing the subsoil on top of the topsoil or mixing the two.

The objection to mixing virgin subsoil with old topsoil is that the former contains very little humus and unless heavily fertilized is disadvantageous as a topsoil until one or two years after it has been broken up, when the action of air and moisture and the penetration of roots and other vegetable matter shall have nitrated it.

The method of subsoiling with Red Cross Dynamite is very simple. In the average soil not underlaid with extremely tough hardpan, holes one and one-half inches in diameter are put down every fifteen feet to a depth of about thirty inches. These holes may be made with a dirt auger or subsoil bar, or a churn drill may be obtained from any blacksmith which will put down the holes very easily in average soil. 


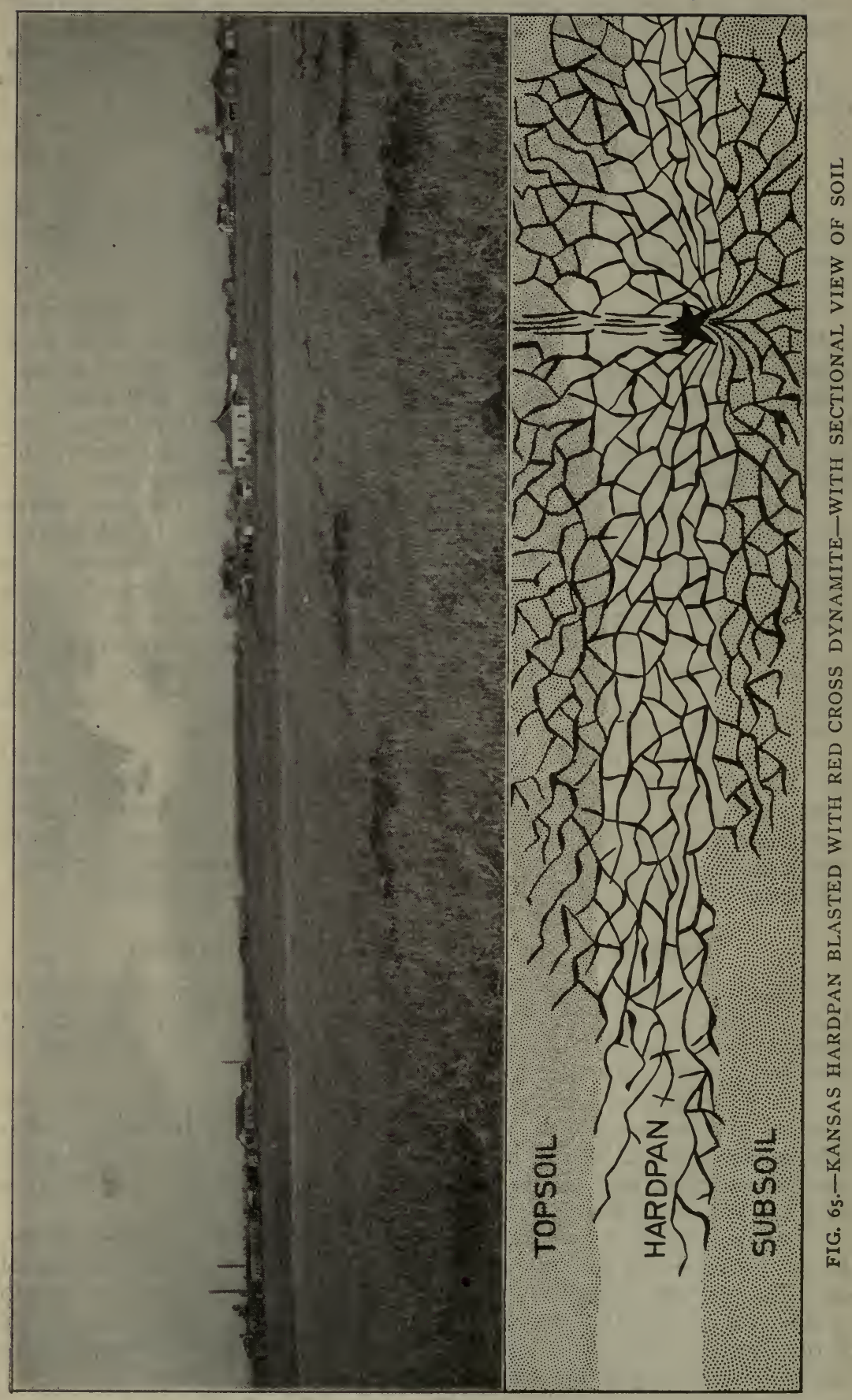


Each of these holes is then charged with a half cartridge of 20 per cent Red Cross Dynamite, which has previously been primed with a No. 6 Du Pont cap crimped on to about three feet of fuse, the length of the fuse required being enough to reach to the top of the ground. Each hole must then be tamped with a wooden tamping stick, using moist earth or clay for this purpose. The tamping must be done thoroughly, as the object of the blast is to crack and shake up the subsoil sideways and downwards rather than to blow the subsoil up into the air. For this reason, subsoiling should be done only when the ground is dry, because when it is wet the blast is almost certain to blow upwards and make a hole in the ground instead of breaking it up sideways.

After a considerable number of holes have been charged the blaster passes from one hole to another, lighting the fuses; the explosions follow about one minute after the fuse is lit. As the charge is usually effective principally underground it is not necessary for the blaster to keep any great distance away from the explosions.

Firing the charges electrically has advantages, the chief of which is that all the blasts over a large area covered by twenty or thirty holes may be fired at one time and the shaking and cracking effect of the various charges is greater because of this united action. This method is, however, more expensive.

Another advantage is that there is much less liability of a misfire, which may occur when the cap and fuse method is used, because the cap may pull out of the cartridge after it is lowered into the hole. This seldom happens when an electric fuze is used.

Detailed instructions for preparing and loading subsoil charges for both methods of blasting will be found on pages 119 to 126 .

\section{Method of Breaking Up Hardpan:}

A large part of the farms of this country are underlaid with a natural hardpan of clay which is completely impervious to water and which lies from ten to forty inches beneath the surface. Such a hardpan is a constant menace to crops. It prevents the storage of moisture and causes the topsoil to wash away in wet weather and dry out quickly in dry weather. Where the ground is level such a hardpan will cause pools of water to form in fields in wet weather which drowns out the vegetation. This hardpan must be broken before good crops can be raised on such land.

When subsoiling under such conditions the exact location of the charge must be determined by the depth of the hardpan. The holes should be placed so that the cartridge is imbedded in the hardpan. When the hardpan is very near the surface the holes should be about thirty inches in depth, but if the hardpan is very tough the holes should not be as far apart as fifteen feet. It is rarely necessary to put them closer than ten feet.

Where the top of the hardpan is from thirty to forty inches below the surface it is necessary to bore the holes deeper so as to locate the cartridge in the hardpan. With the hardpan reaching to within thirty inches of the surface, for instance, and a charge placed in a thirty-six 


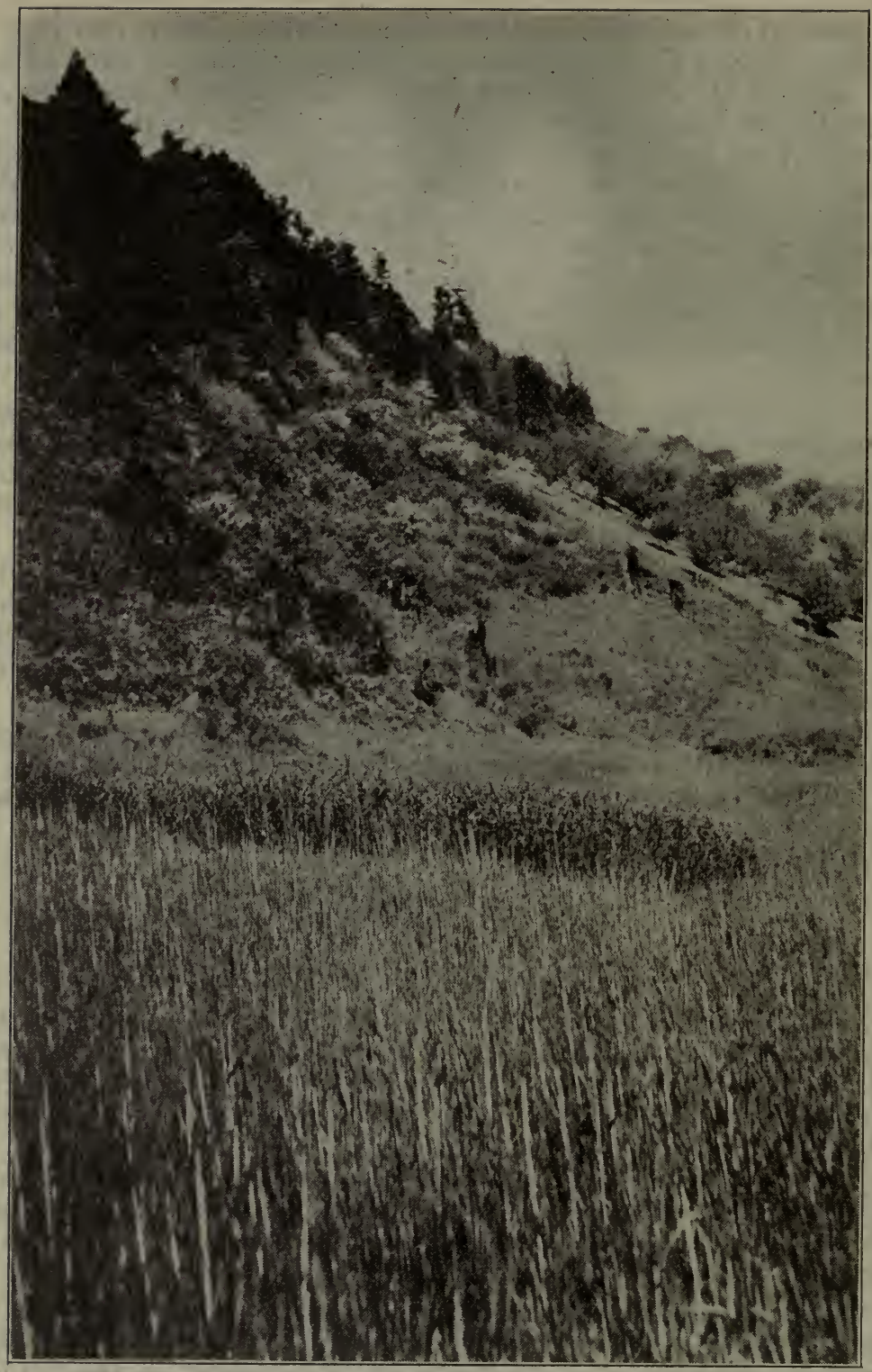

FIG. 66.-NOVEL PROOF OF VALUE OF SUBSOILING

Above view shows a California oatfield recently cleared of stumps. Wherever a stump had been blown out, the oats grew a foot higher, as shown by the dark streak. The same blast that threw out the stump broke up the subsoil underneath it. In regular subsoiling, the effect is broader because the charge is confined underground.

We are in receipt of a letter from Mr. Bud Lane, of Hope, Indiana, who has done blasting for a number of years. In his letter he tells of an experience he had with a fariner.

He blasted, for this farmer, a field of stumps; payment for this work was not to be made until three months later. When Mr. Lane called to obtain settlement the farmer claimed that the number of stumps for which he asked payment was too great. Mr. Lane said that he could prove that his estimate was true, but the farmer thought that impossible as the field was sown in wheat. They went out to the field, and on each spot where a stump had been blown out the wheat was several inches higher than in places which had not been affected by the blasting. Mr. Lane very easily proved his point in this way. 
inch hole and well tamped in, the hardpan will be broken to a depth of six or seven feet from the surface and sideways six or seven feet in all directions. Under these conditions holes at fifteen feet centers will probably be close enough because of the considerable volume of loose compact soil above the hardpan.

As hardpan frequently runs under the surface soil irregularly, the depth of the holes will have to be varied to suit the conditions in different parts of the field that is being subsoiled. The man putting down the holes can easily decide the necessary depth by the amount of resistance that the soil offers to the auger or bar.

The main thing to guard against is the location of a charge beneath a thin section of hardpan, as such a charge may break up the soil underneath the hardpan but may not break the hardpan. When the hardpan is thin it is better to place the charge a little too high than a little too low.

In parts of California and in a few other sections of the country, the hardpan is so thick and hard as to have the characteristics of stone. In such soil the charge should never be less than a whole cartridge at fifteen-foot spacing, and owing to the high cost of putting down the holes, it is often more economical to use twenty-foot spacing with two or three cartridges per hole. The high value of California land when under cultivation warrants the high cost of such subsoiling.

In rocky hardpan running near the surface a whole cartridge every ten feet will probably produce better results than four cartridges every twenty feet. While the holes for ten-foot spacing need not be quite so deep as for twenty-foot spacing there will be four times as many holes.

\section{Opinion of a Distinguished Citizen}

A pioneer in subsoiling with dynamite was General Samuel J. Crawford, ex-Governor of Kansas. Below is a letter from him that tells of his experience:

"I am glad the good work of blasting the compact subsoil and hardpan is moving along in the east as well as in the west, whether it be for the planting of trees, grain or anything else that grows from the ground. If the subsoil is loosened so that the rainfall can penetrate the earth, the roots of grain, grasses, trees, etc., will follow the water to their natural depth and draw their nourishment from five or six feet of soil instead of five or six inches of surface soil, as heretofore. Besides, the blasting creates sub-reservoirs in which to store the surplus rainfall which will supply the roots of the growing products with moisture when the dry season is on. Again, if the ground is loosened so the water can pass down into sub-reservoirs, there will be no standing water on the surface to damage the crops or keep the farmers back with their work. Such treatment, properly applied, will revolutionize the agricultural and horticultural industries throughout the country.

"The government is spending millions of money for irrigation purposes in isolated places, which, from the nature of things can only benefit a few people, while the blasting process will benefit all the farmers and fruit growers at comparatively a nominal expense. By this process most of the worn-out farms in New England and throughout the country can be reclaimed and made to produce good crops. All that is necessary is for the producers to grasp the idea and learn how to handle explosives." 


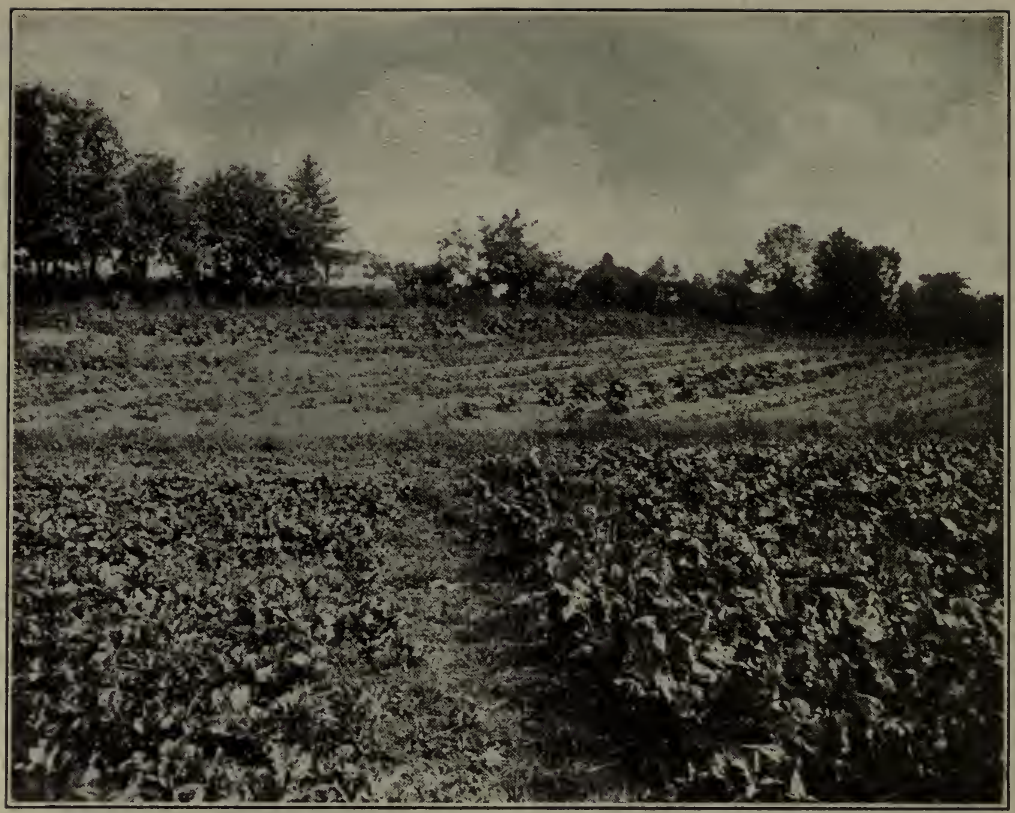

FIG. 67

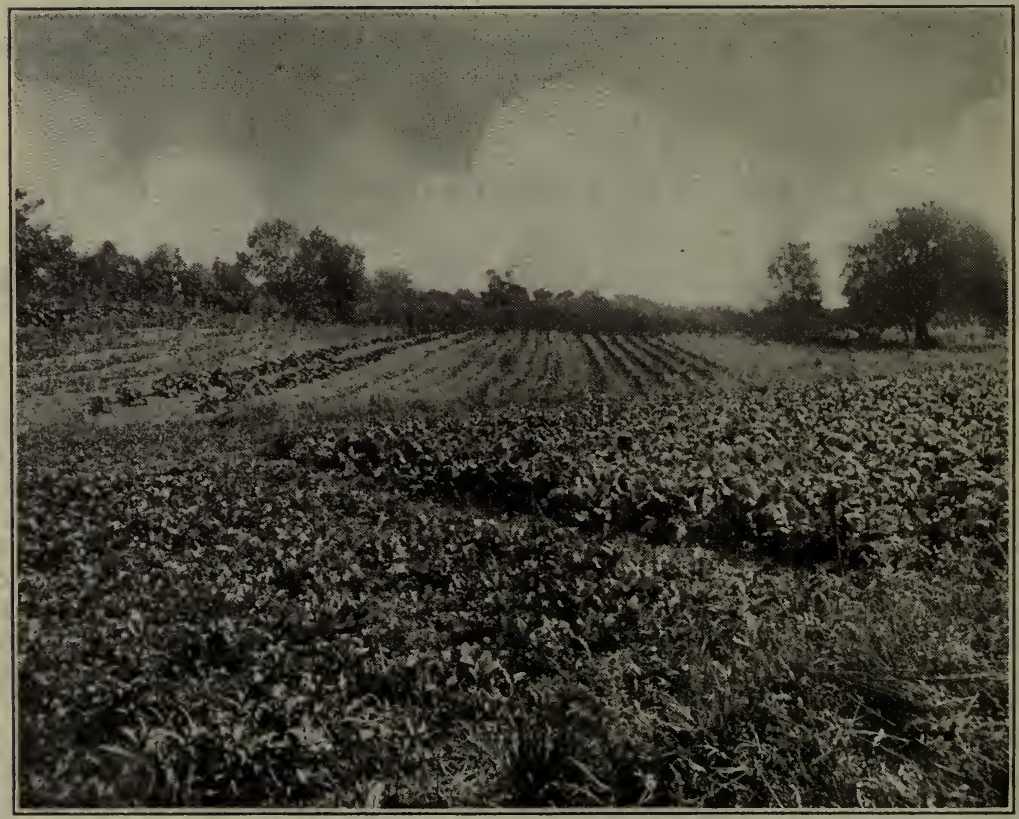

FIG. 68

Both cuts are photos showing two plots of garden beets, the ones to the right planted on ground subsoiled with Red Cross Extra Dynamite ten days after those on the left were planted on ground not subsoiled. The dynamited beets matured very early and brought 75 cents per dozen bunches, the others were much later and brought only . 40 cents per dozen bunches. Farm of H. B. Decker, E. Stroudsburg, Pa. 


\section{Cost of Subsoiling With Red Cross Dynamite}

The following table will give an approximate idea of the cost of subsoiling, referring to the cost of materials only:

\begin{tabular}{|c|c|c|c|c|c|c|}
\hline 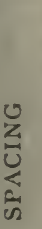 & 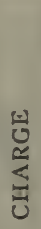 & 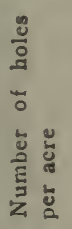 & 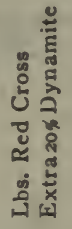 & 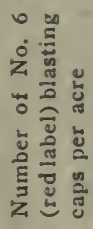 & 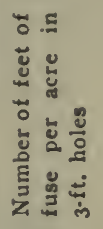 & 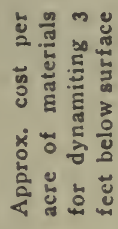 \\
\hline 15 & $1 / 2$ & 194 & 49 & 194 & 582 & 12.20 \\
\hline \multirow[t]{2}{*}{18} & $1 / 2$ & I 28 & 32 & I 28 & 384 & 8.00 \\
\hline & I & 128 & 64 & I 28 & 384 & I I . 20 \\
\hline \multirow[t]{2}{*}{20} & $1 / 2$ & 109 & 28 & 109 & 327 & 6.93 \\
\hline & I & 109 & 55 & 109 & 327 & 10.98 \\
\hline
\end{tabular}

The labor cost will of course depend on the wages paid and the ease or difficulty with which the holes are put down. Where very tough hardpan is encountered the cost of putting down the holes may amount to nearly the cost of the explosives and supplies. On the other hand, where only a plow sole is encountered the holes can be put down very rapidly and cheaply, and for that reason these tables do not include labor cost.

Where soil conditions are easy the holes can be put down at the rate of about thirty per hour. Where soil conditions are difficult it may take five minutes or more per hole. Priming the cartridges and tamping them in will take from two to three minutes per hole. In general, subsoiling will seldom cost less than $\$ 10.00$ an acre and will rarely cost more than $\$ 25.00$ an acre.

\section{Second Year Results Greater Than First}

Anderson, S. C., September 23, 1912.

In reference to breaking land with dynamite for farming purposes will say that the land so broken in the Spring of 1911 shows a greater improvement than it did the first year. The upland corn was at least $40 \%$ better than the corn raised on adjoining land that was not dynamited. I dynamited four acres this year and I find a great difference in the corn compared with the adjoining land. The greatest difference, as stated above, is the second year. I also broke some land for cotton late in the spring this year and I am much pleased with the results, as the cotton is still green and blooming and has stood the dry weather better than the other land.

Yours very truly, 


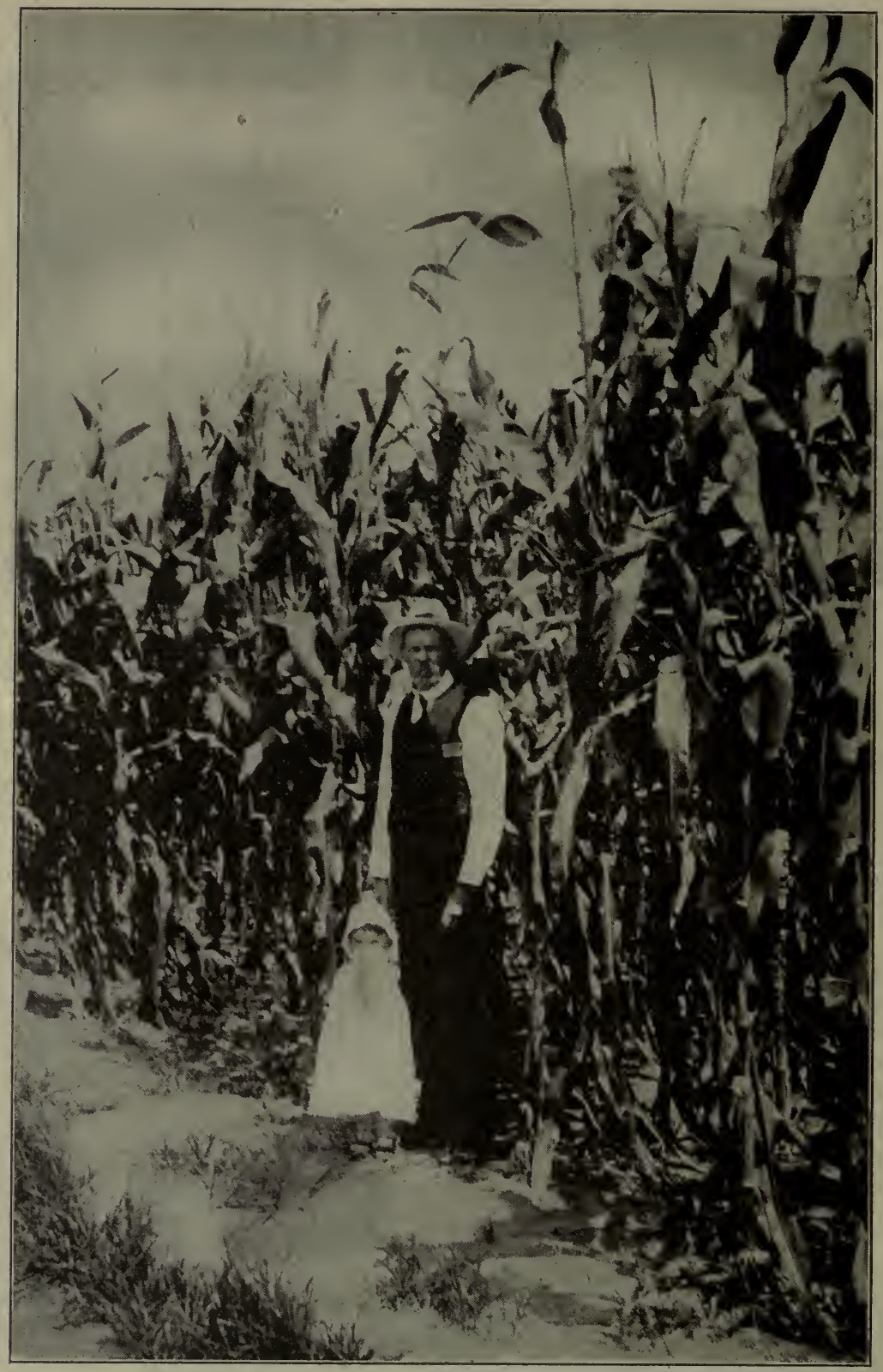

FIG. 69.-DEEP PLOWING MAKES BIG CORN YIELDS

One of the first experimenters with dynamite for deep plowing was J. H. Caldwell, of Spartanburg, S. C. He subsoiled a portion of his corn-field with dynamite and increased the yield one-third over that of the portions not subsoiled. A committee of the Chamber of Commerce of Spartanburg inspected this corn and certified to the accuracy of the figures. 


\section{Effects of Subsoiling With Red Cross Dynamite on the Action of Commercial Fertilizers}

Commercial fertilizers are ordinarily added to the soil in a very fine and readily soluble condition, and are usually incorporated with the first few inches of soil at or just before the time of seeding. This keeps them from being carried further into the soil mass through cultivation. During heavy rains when there is a considerable amount of surface run-off of the excess of water, large parts of the fertilizers thus added are at once brought into solution and lost by being carried away by the surface drainage. The fertilizing elements can, however, be carried into the deeper soils by transfusion through the soil moisture or they can be carried down with percolating water, provided the subsoil has been made sufficiently porous to permit of such percolation. Where soils are at all packed both of these processes are materially hindered, but can be relieved by a thorough breaking to a sufficient depth. Except in very rare instances these troubles occur beyond the reach of the plow and Red Cross Dynamite becomes necessary.

Thus subsoiling with dynamite will result in an enormous decrease in the loss of fertilizers by washing and also in inducing a deeper development of roots in search of foods, the importance of which is already so thoroughly understood by those now interested in promotion of deep subsoiling.

The use of a large amount of fertilizer is largely handicapped by even a short season of drouth. During the spring, when the soils contain large amounts of moisture, heavy applications of fertilizers result at once in a very luxuriant growth of succulent but shallowrooted vegetation. A plant thus developed is poorly able to combat dry soil conditions. Deep subsoiling done in connection with such heavy applications of fertilizers naturally brings about a much better soil moisture condition. This, of course, permits of very vigorous and rapid growth during the spring both above and below the surface. It also safeguards the plants against the dry summer.

For the proper development of a plant certain foods and conditions are necessary. If one of the foods is lacking or deficient in amount, the growth of the plant will correspond with the amount of this food available, and will not be influenced beyond this point by excess of other foods present. Water is, of course, one of the essential foods, so when additional foods are added as in chemical fertilizers it becomes necessary to furnish the plant with more water.

\section{Farming Menaced by Loss of Water}

\section{Has Been Lowered Almost Two Feet a Decade, Expert's Report Shows}

WASHINGTON, March 29.

The ground water of the United States, upon which the agricultural wealth of the cuuntry depends, is lowering at the rate of nearly two feet a decade, according to Prof. W. J. McGee, soil and water expert of the Department of Agriculture. He arrived at this conclusion from reports from 35,000 different points in the United States, covering every county.

Unless means are taken to check the constant lowering, dire results from drought and failure of crops are likely to ensue, declared Professor McGee.

Investigation has shown that freshets and floods are allowed to carry off a large percentage of the rainfall from lands where it should be retained. Intensive farmers near large cities, whose land is worth $\$ 400$ or $\$ 500$ an acre, Professor McGee says, take pains to keep every drop of water that falls on their land from leaving it.-From Philadelphia North American. 


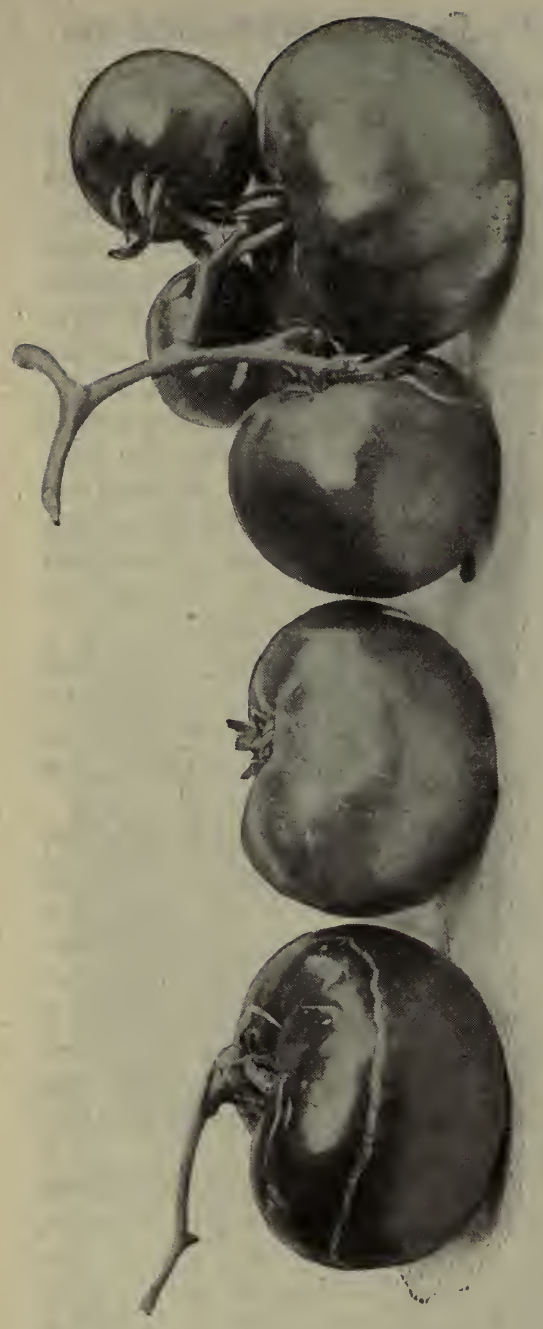

ฆั่

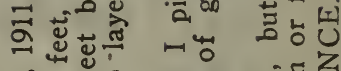

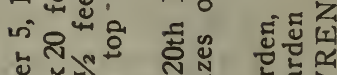

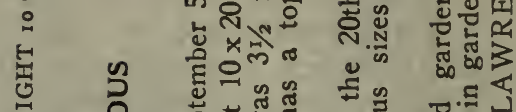

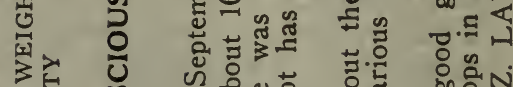

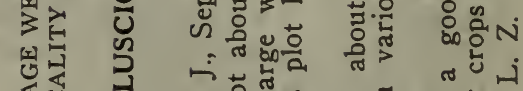

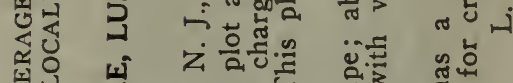

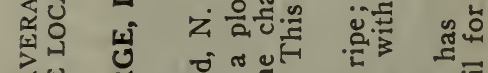

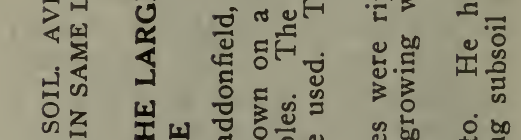

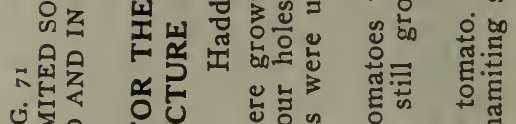

$\because<$

प U एक्ष

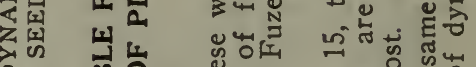

目 0 ०

ż

$z$

3.

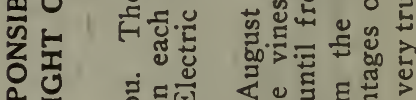

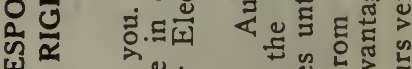

幽

纯

杄

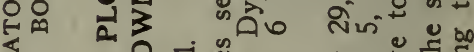

乙워

落

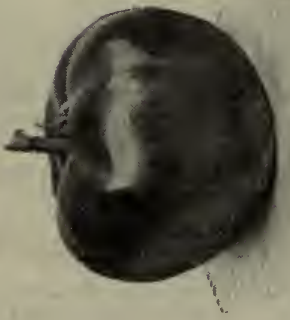

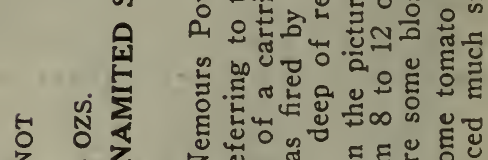

选出

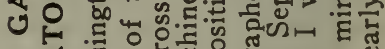

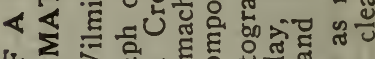
站

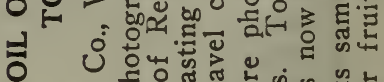
勿

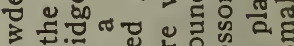

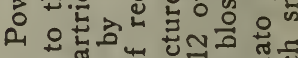

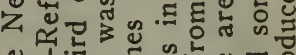

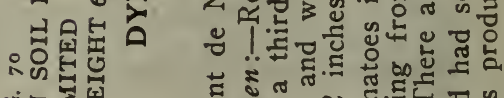

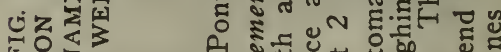
क 즘 U人

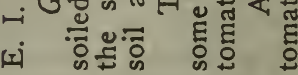




\section{Experience in Terracing}

From “St. Louis Star Farmer," Feb. 23, 1912.

Editor, "The Weekly Star Farmer:"

Land that has washed down the hill, down the branch and down the river is gone, and gone forever. Wherever the top soil is thin and sandy, a tight clay lying close to the surface and the country hilly or rolling, washing is sure to follow. The precious and friendly raindrops, like fire, are a good servant, but a bad master. If allowed to wash away all the top soil, with its plant food, they become man's worst enemy.

In the four years I have occupied my present place I have not suffered the loss of one foot of top soil from washing, and my land is hilly. I solved the problem with dynamite. At the same time I solved several other vastly important problems -the conservation of moisture, destruction of insects, and fine, porous pulverizing of soil for cultivation.

It is terracing with dynamite that we are now considering. To do this, make a land level of three pieces of scantling or any cheap, rough, straight-edge stuff; one for your bench to be 8 to 12 feet long and two pieces of equal length $2 \frac{1}{2}$ to $3 \frac{1}{2}$ feet long. At a hardware store buy a 75-cent carpenter's spirit level. Secure it on top of bench in the middle by ten-penny nails partly driven. A more simple and accurate device could not be imagined; but if you prefer, buy a land level for $\$ 10$ or $\$ 15$. Two men can level fifty or more acres a day. One takes the level and one follows with a hoe, chopping out a hoeful of dirt at each end, thus indicating your terraces. Or a man may follow with turn plow or twister, discarding hoe. Throw several deep furrows up for terrace. Now, with a number of $1 \frac{1}{2} 2$-inch iron drills follow in last furrow and drill holes 24 to 34 inches deep, every 10 to 14 feet. Insert a half stick of Red Cross Extra 25\% Dynamite, equipped with cap and fuse. Tamp well with an old broom handle or other wood tamp, light at first and gradually harder and harder till hole is filled. Use clay for tamping. Split end of fuse to effect a powderpan; turn back and light a row at a time with a torch or matches. Use your best judgment in spacing terraces, according to steepness of your grade. Much land may be saved for cultivation by dynamiting close terraces alone, and only throwing every third or fourth one up with plow. It is marvelous how this will hold hilly land together. Save your fresh land and reclaim that has begun to wash. Besides being the best means for terracing, you will literally irrigate your farm with these storehouses of moisture and will be astonished beyond measure at the ease of cultivation and crop returns.

I travel all over the Southern states from time to time, meeting nurserymen and orchardists. I have never yet seen a man who had used dynamite for stump blowing, tree setting, subsoiling or ditching who was disappointed with results. For my part, I use it for all these purposes on my place. It has more than proven its worth.

ARTHUR E. COLE,

High Point Farm and Nursery, DeKalb Co., Ga. 


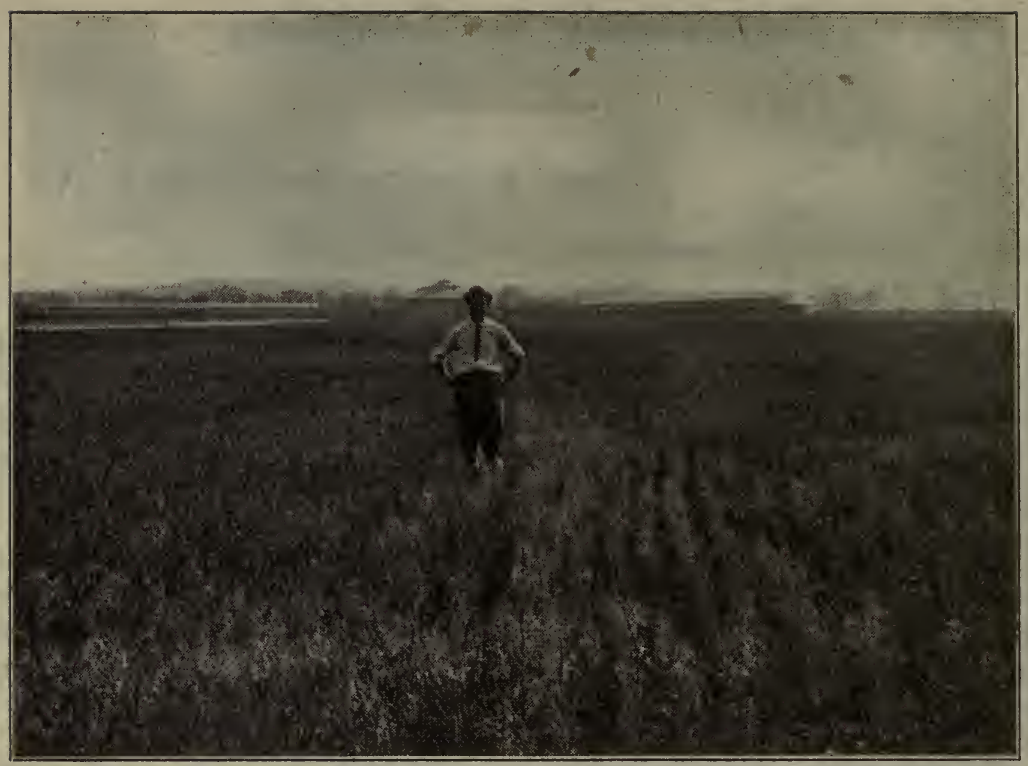

FIG. 72

OATS GROWN ON N. Y. STATE FAIR GROUNDS AT SYRACUSE ON GROUNDS NOT PLOWED WITH DYNAMITE. NOTE THIN ROWS, SHORT STALKS AND POOR HEADS

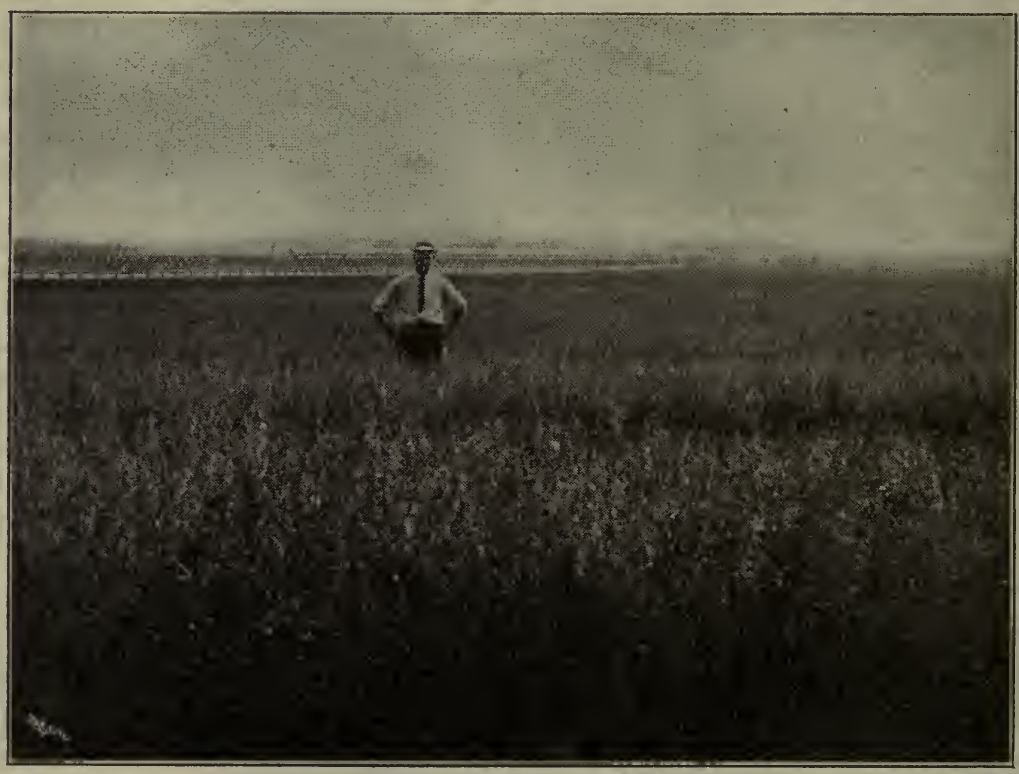

FIG. 73

OATS GROWN ALONGSIDE OF CROP IN UPPER PICTURE BUT ON GROUND DEEP-PLOWED WITH DYNAMITE. NOTE HEIGHT, VIGOROUS GROWTH AND WELL DEVELOPED HEADS 


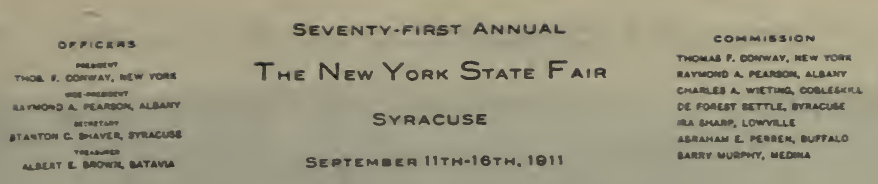

Syracuse, R.Y. Jily 27, 1911

ร. I Du Pont Do Remoure Powder Co., 90 กзаt Street, New York City.

Gentlemen:-

I am pleased to infort you that your sub-solling work has proven a great success. The oat are growing up very nicely and $\mathbf{1 1 l}$ be in full bloom by the tiwe the Fals opene. I am having the roads bullt now so that people can walk over and cee what excellent wark the Sub-golling lo doing in the bard clay 011 which you had to work with.

The facts are that we were unable to grow anything In the way of oats or any other thing until you ingroved the land by the work ae stated above and I wh to eay here that wo did not do any, fertilizirg, whatever, to thlo plece of land.

I ould be glad to recommend this to anyone, especlally the farmers, to whom the use of this Sub-Solling prooese, to my alnd, will do wonders to lmprove thelr crops.

ARP/8

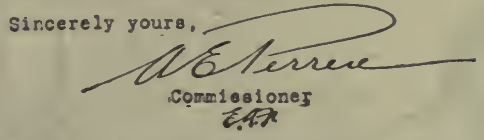

The photos of the crops on the undynamited and dynamited land, taken the same day, are reproduced on the opposite page.

\section{LA T ER}

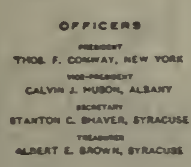

\section{SEVENTY-SECOND ANNUAL}

\section{The New York State Fair \\ SYRACUSE}

SEPTEMEER OTH-14TH, 1912

Sугасuæ0, Y. Y.. Fezruary 26th. 1912.
COMmission

THomus r. COMWAT, WEW ronk

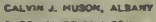

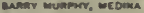

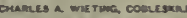
Geonse 1 . ORescoul svencuns tu Gasp. Lowvine

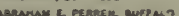

E. I. Du Port da Kemours Poscer Co.,

vilmington, Delaware.

Gantlezen:-

$$
\text { In ecfererce to our talk nith gour }
$$

representetive, in =egard to the alount of oato taken

from the land which was partiy sub-solled with cynamite,

ty your Corpary. We would oey that wa floughed up

betweet an acre and three quartere to two acreo. The

acre which was beneflad by the sub-90121=b gare forty

to forty-fire buehels of oats, and the remalning acre

y ledcel therty to twenty-fítre bushele. The extreme land

of the tro acree firthereat aনcy $f=c m$ Frero oub-8011 started

was pracilcaliy a total loss..

Sincerely youra, 


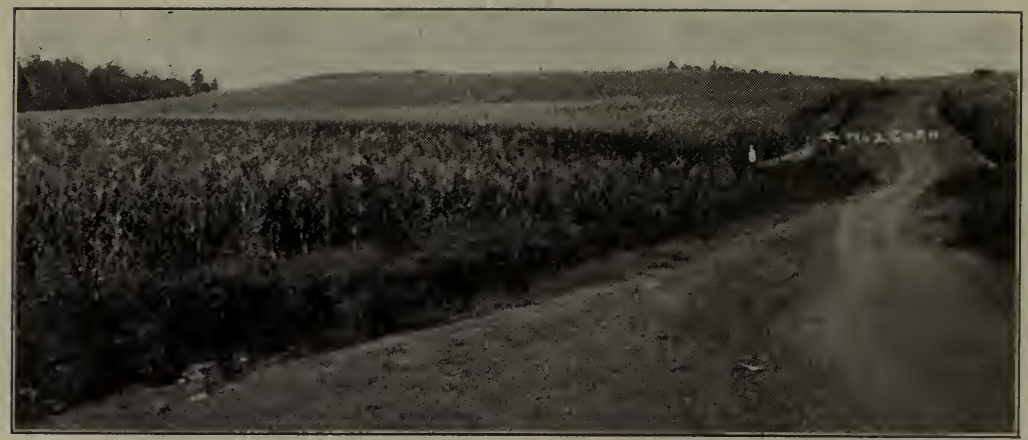

FIG. 74

SHOWING CORN GROWING ON SUBSOILED GROUND (ARROW POINT)

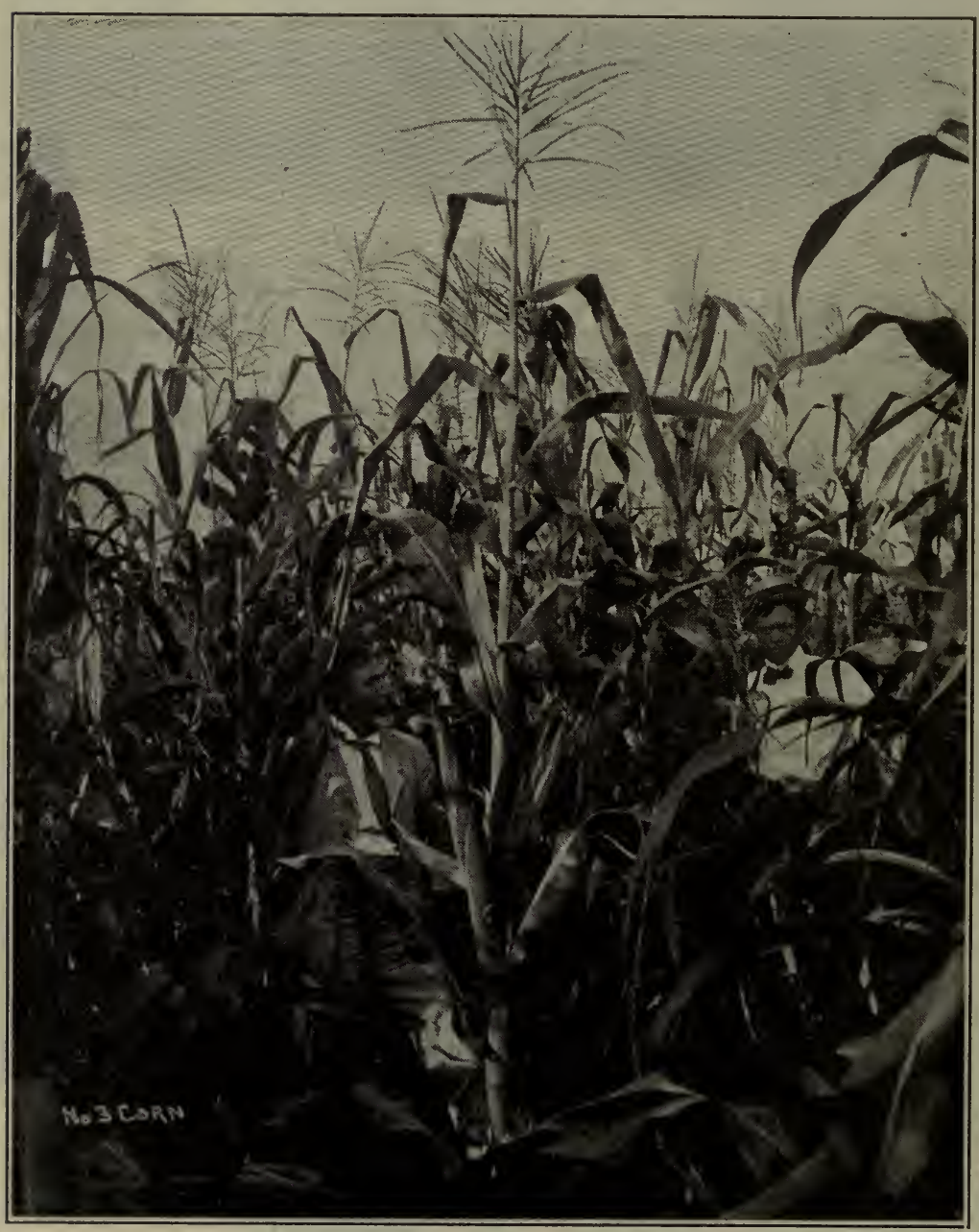

FIG. 75.-MR. FOWLER STANDING IN CORN ON SUBSOILED GROUND 


\section{Record Crop on Dynamited Ground}

From OHIO STATE JOURNAL, Columbus, Ohio, August, 10, 1911.

Among the visitors to Columbus yesterday was J. S. Fowler, of Anderson, S. C. He is one of the original dynamite farmers of the South, the new method of farming which is making the South proof against the drouths which have so often blasted the hopes of its farmers.

He brought with him pictures showing corn fields planted by the dynamite method, to prove that the stories he told of the corn crops were not fabrications, absurd as they might sound to the ears of farmers in what is supposed to be one of the great corn-raising sections of the country. The land in the western part of South Carolina is good, and Mr. Fowler said that under the old method he had raised 100 bushels of corn to the acre on his plantation, which consists of 2,000 acres, but this yield has more than doubled under the new method.

This year he prepared four acres with dynamite. Half a stick of 40 per cent. dynamite was used to each fifteen feet square, the dynamite being placed in holes punched in the ground and then fired. It cost $\$ 18.00$ an acre for the dynamiting. This stirred up the ground from three to four feet deep. It was plowed and harrowed in the usual manner and the corn drilled. Just before he came to Columbus, the time when the pictures were taken, officials from the government agricultural experiment station visited the field and estimated that the corn would yield 260 bushels to the acre. Mr. Fowler says that he does not believe that it will go that high, but states that he expects over 800 bushels from the four acres. Some of the stalks of corn have from three to five ears and all are large. The corn is about fifteen feet high and very uniform. 'Next year he expects largely to increase his dynamite acreage. One dynamiting does for years, it is said, and the corn requires but little rain, as what does fall is held in the ground. Mr. Fowler says that the cotton crop in the South this year will be a record-breaker, in spite of the reports of dry weather. "We have learned many lessons," he said. "We are plowing deep for our cotton and the dry weather does not damage us as it once did. This year streams are dry, the cotton mills have closed because of failure of water power, but there has not been any damage done to the crops. Our new methods of farming have made us practically independent of the mid-summer drouths, and the cotton speculators who are counting on a short crop because of dry weather are going to be badly stung.

"Cotton has never looked better than this year in all the Southern States in which I have been, and the weather has never been so dry. Under old methods of planting the crop would have been almost a total failure. But now it does not show any damage at all. The Southern farmer is taking up new methods, and already he is beating the big yields once reported from Northern farms. This fall hundreds of old farms will be dynamited and next year they will raise immense crops of corn and cotton. It costs money, but we are getting it back and have never been so prosperous." (See page 87.) 


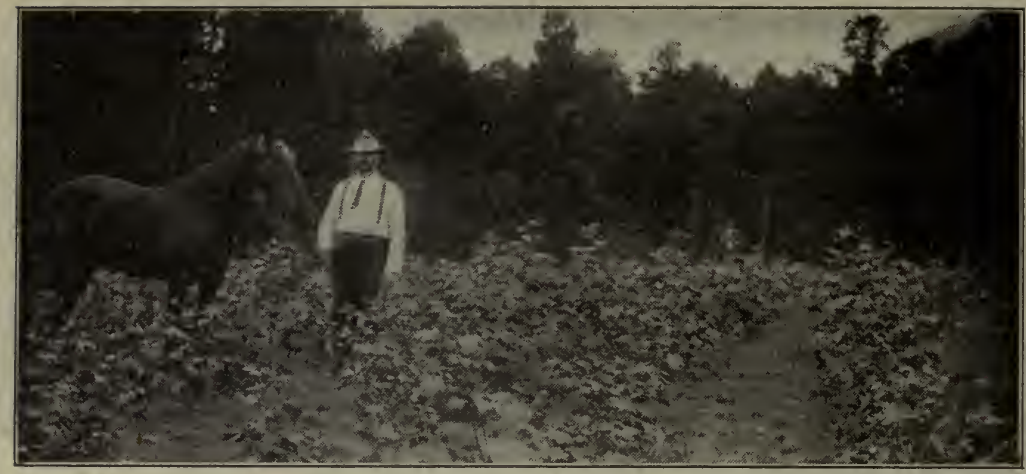

FIG. 76.-COBB'S COTTON, 1911-NOT SUBSOILED

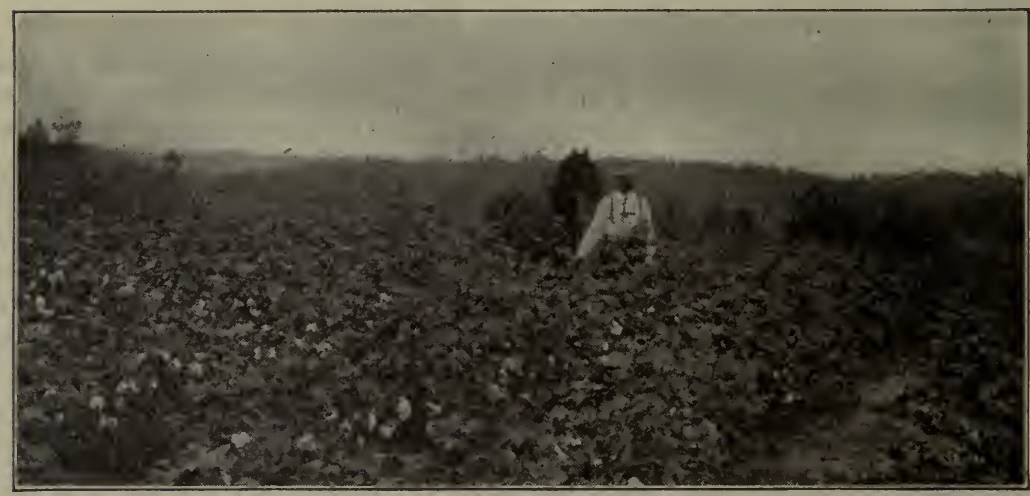

FIG. 77.-COBB'S COTTON, 191I-SUBSOILED

\section{Dynamiting Subsoil of Cotton Field Doubles Crop}

Walhalla, S. C., August 5, 1911.

Gentlemen: I wish to tell you about my experience of using dynamite on part of a field of cotton. The size of the plot was thirty feet by ninety feet. The soil of the whole cotton field was given the usual cultivation before sowing the seed. I am very greatly pleased to say that the small plot of dynamited soil has shown a better crop, in fact the yield from this dynamited soil will be, in my judgment, between 800 and 1,000 pounds per acre, or more than twice as many pounds of seed cotton as will be picked from the same size of plot adjoining the dynamited plot.

The success of this tested plot is so assured that I am going to use dynamite on thirty to sixty acres of land now growing good crops. I feel that dynamiting the subsoil of these acres is going to result in greater crops. I figure that I can do this at a cost of four or five dollars an acre. In dry soil I use a quarter of a dynamite cartridge in holes placed fifteen feet from each other. This takes fortynine sticks of cartridges of dynamite to the acre, approximately twenty-five pounds. My test of dynamiting the cotton plot was the means of showing me how I can make my acres grow bigger, better and more valuable crops at small cost and increase the fertility of my farm.

W. R. COBB,

Steward Oconee County Poor Farm. 


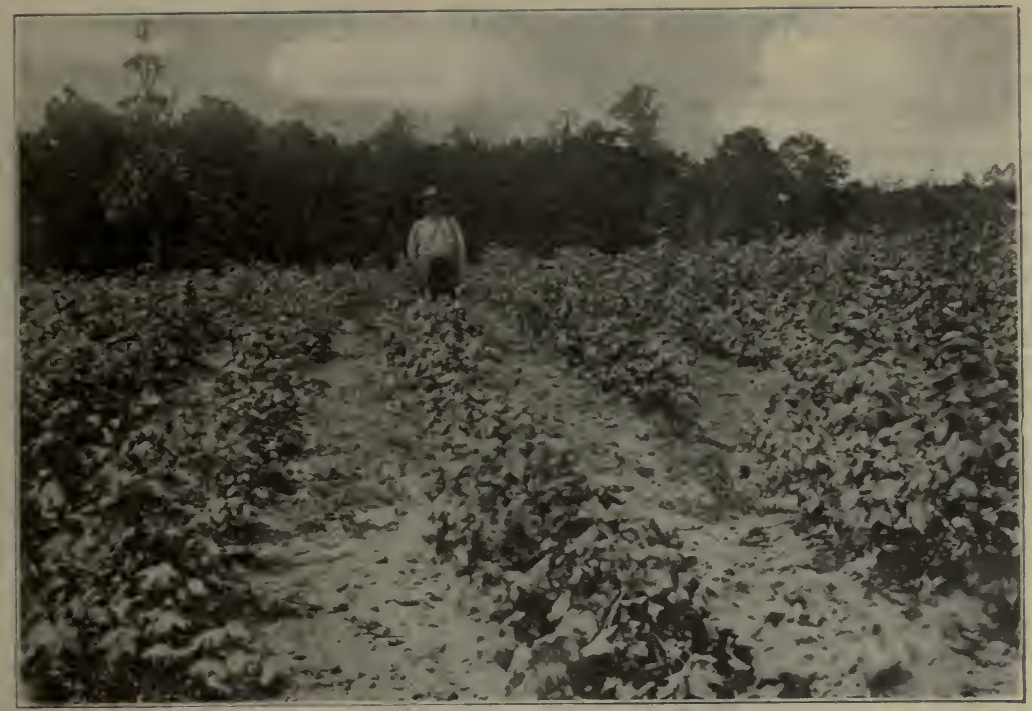

FIG. 78.-COBB'S COTTON, 1912-NOT SUBSOILED

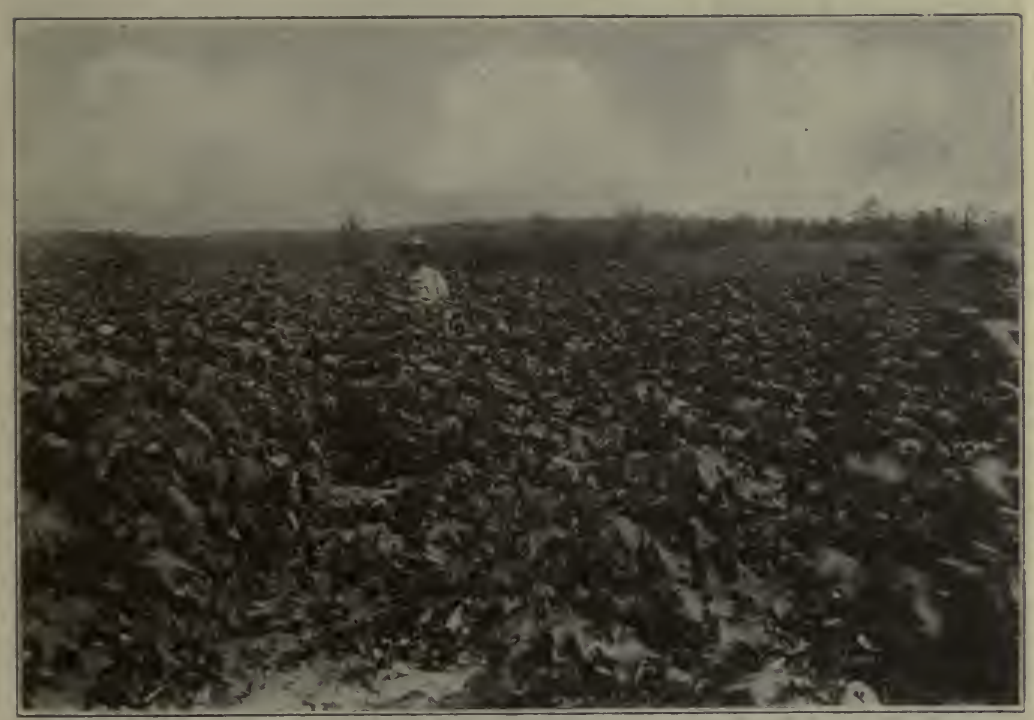

FIG. 79.-COBB'S COTTON, I9I2-SUBSOILED

Under date of Sept. 14, 1912, Mr. Cobb wrote that the 1911 crop on the subsoiled plot yielded 1,500 lbs. per acre as compared with $\$ 00$ lbs. yield per acre of the unsubsoiled portion, and that the 1912 crop would probably be still better on the subsoiled plot. Both plots received the same cultivation and the usual fertilization with stable manure and guano. 


\section{Another Big Yield of Cotton}

Regarding the dynamited field of cotton of J. G. Spivey:

Eatonton, Ga., September 21, 1911 .

Mr. Spivey told us last week that he picked two and one-quarter bales of cotton off of the one and three-quarters acres of dynamited land the first picking and says he will get five bales from this piece of land when he finishes.

This cotton has been the talk of the country, and a great number of people have visited this particular spot. We are sure it is going to do your Company a great deal of good in the sale of dynamite.

One of the pictures shows dynamited cotton on one side of the road and cotton where dynamite was not used on the other. It does not do full justice, as the cotton dynamited is about five or six times as good, botli in size and fruitage, as that which was not dynamited. No one can well conceive the difference unless they were on the ground like the writer was some thirty days ago. HEARN \& GREEN HDWE. CO.

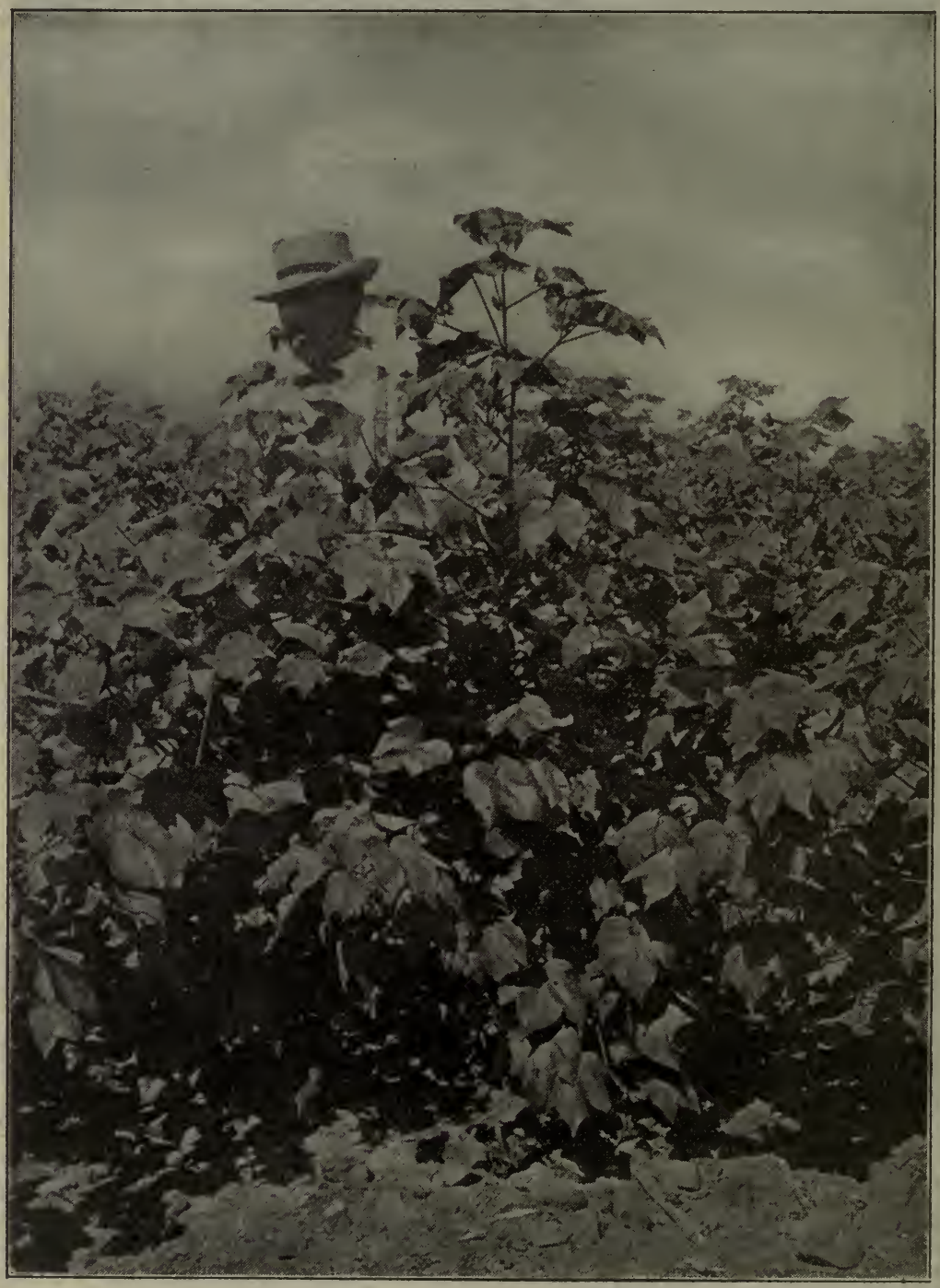

FIG. 80.-SPIVEY IN HIS $21 / 2$ BALE PER ACRE COTTON 


\section{Red Cross Dynamite Increased Cotton Yield $150 \%$}

“Thirty-five dollars' worth of Du Pont's Red Cross Dynamite resulted this year in an increased cotton yield of 150 per cent.

Land that never before had produced over one bale to the acre has this year yielded two and one-half bales of 500 pounds each. Other lands lying immediately alongside the dynamited land, and which were treated the same in every particular save dynamiting, made only one bale to the acre; while still other land removed only the width of a plantation roadway from the dynamited field yielded less than one-half bale to the acre.

The above highly profitable cotton-growing experience was realized this year on the plantation of Mr. J. G. Spivey, near Eatonton, Ga., and has been witnessed throughout the year by hundreds of interested citizens of Putnam County.

The land is a red, sticky soil, located on the summit of a ridge not less than one-quarter of a mile from the nearest running water of any kind. Heretofore the average crop has been less than one-half bale. This year the splendid yield of two and one-half bales has been realized; and that, too, when at least enough bolls to make a half bale dropped off during some cool nights in July. To Du Pont's Red Cross Dynamite is due the credit.

That dynamiting is the direct cause of the increased yield is evident from the fact that on all lands not dynamited, yet prepared and cultivated in exactly the same way as the dynamited land save in this one particular, the usual yield of only one bale was made, while the dynamited field gave two and one-half bales to the acre.

When the land had been disced and subsoiled, it was laid off in six-foot checks. At each check was placed a charge of Du Pont's Red Cross Dynamite.* The blasting broke and tore the land thoroughly to the depth of from three to five feet through subsoil and hardpan. The ground was again disced and harrowed, then allowed to stand till planting.

Cleveland big boll variety of cotton was used, being planted in three and one-half foot checks, and thinned to two stalks in a hill. A perfect stand was secured, and the crop grew rapidly. Beginning in early June and lasting for seven weeks a severe drouth came upon the cotton at its most critical time. Cotton on undynamited land lying immediately alongside the dynamited field stopped growing and also wilted. Dynamited cotton suffered no delay whatever, no wilting or other evidences of injury. In August a long-continued rainy season caused a much too rapid growth and fruiting of undynamited cotton, with a consequent heavy falling off of squares. This was not experienced in the Spivey dynamited field.

Long after other cotton had ceased to grow this dynamited cotton continued to spread out and to fruit, and even to this day, the 25 th of October, it has a large number of new blooms upon it, while other crops shown in the photographs are dead and the entire crop made and gathered. During the year the dynamited cotton has not suffered a day from worms or blight of any kind. The average height of dynamited stalks was five feet, while that not dynamited ranged from eighteen to thirty inches. Dynamited cotton fruited very heavily and thoroughly. In hills of two stalks 255 bolls were counted, while in hills of one stalk 158 bolls were to be seen.

This field of dynamited cotton has been the sensation of Putnam county's farming circles this year. Many visitors have gone out to witness this modern method of farming, and every one confesses it to be the finest field of cotton ever grown in Putnam county."

- The writer of the above states that Mr. Spivey's land was laid off in six-foot checks and that at each check a charge of dynamite was exploded. Unless the subsoil on this plantation was exceptionally hard, more dynamite was used and more work done on this subsoil than was necessary. Ordinarily, placing charges at the corners of is foot squares as explained above is entirely sufficient. Another point to bear in mind is that blasting with dynamite is not necessary every year, as the effect endures many years when the work is properly done. So that cost can be distributed over, at least, five crops, thus greatly reducing cost of cultivation per crop. 


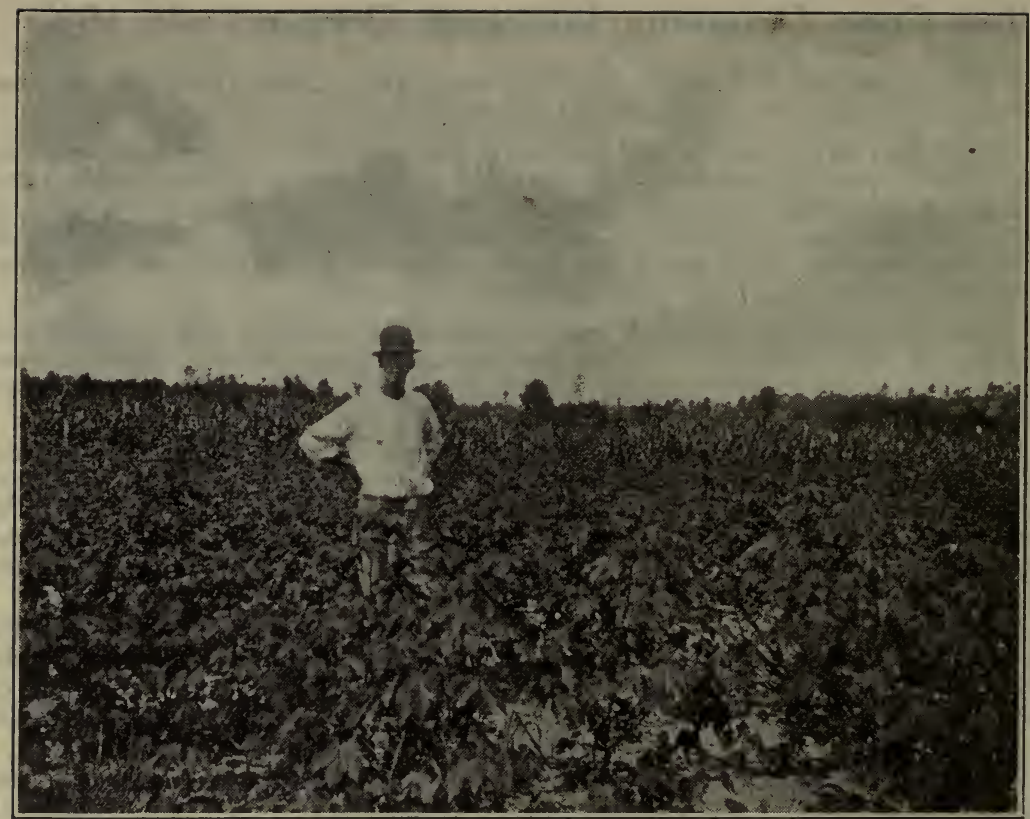

FIG 81.-COTTON NOT SUBSOILED, DEMONSTRATION FARM OF INTERNATIONAL HARVESTER CO., BROOKHAVEN, MISS. SEE PAGE 104

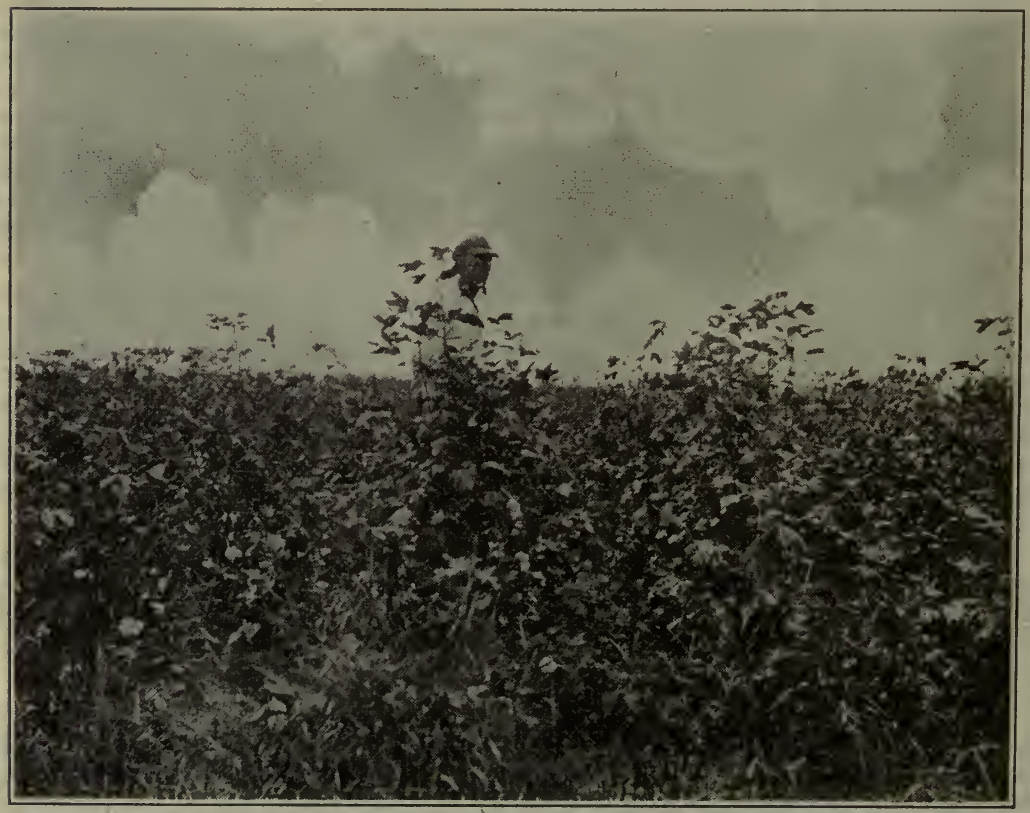

FIG. 82.-COTTON SUBSOILED WITH RED CROSS EXTRA DYNAMITE, SAME FARM. SEE PAGE 104 


\section{Remarkable Results Achieved on Barren Ground by Dynamiting Subsoil on Farm of Agricultiural Experimental Station, Clarksville, Tenn.}

(See cut on page 76 )

Under date of August 16, 1911, Mr. S. L. Smith, Superintendent of City Schools, Clarksville, Tenn., writes as follows regarding "Subsoiling with dynamite":

"During December, 1910, I subsoiled one acre of ground on the Experiment Farm here which is run under the direction of the Agricultural Department of the joint High Schools, which ground before that time had produced nothing for several years. It was 'worn-out' land. This subsoiling cost about $\$ 12.00$ per acre, but as compared with the excellent results obtained, I consider that it has paid us well.

"The corn shown on the left of the photograph which I sent you is on the dynamited ground. That on the right of the same photograph represents corn planted and cultivated in the ordinary way without any scientific methods-no subsoiling. No fertilizer used on either the subsoiled or unsubsoiled ground, but well cultivated. Otherwise, the land not subsoiled was considered better than that subsoiled.

"Both acres were planted the same day and the subsoiled land will yield possibly three times as much as that not subsoiled. In fact, it is the best corn in the county, and all the farmers of the county who have seen it realize there is something in scientific farming. We selected the poorest land we could find, and it is my intention to subsoil more ground this fall."

\section{A Director of Agriculture Convinced}

\section{Sacramento Valley Irrigation Company.}

During the past week your Messrs. Jones and Doremus have given the farmers of Glenn County a very fine demonstration of the use of dynamite in farming.

There is no question but that hundreds of pounds of your Red Cross Dynamite will be used here during the next year as a result of the work of your representatives.

While there is no hardpan through this section of the west side of the Sacramento Valley, the loosening up of a big body of soil in land where trees are to be planted will give the tree roots a perfect environment for growth and development, and be of great value. The opening up of lands that have been pastured when wet and otherwise abused will be accomplished by the use of dynamite in a very effective manner. Your work here is appreciated.

W. S. GUILFORD,

Director of Agriculture. 


\section{Duration of Subsoiling With Red Cross Dynamite}

Ty pibicity given to these astonishing results which point to a revolution in farming methods, has naturally created much inquiry in the minds of the farmers as to the cost of subsoiling and the length of time before subsoiled land will have to be again subsoiled in order to keep it open.

The cost averages about $\$ 15.00$ an acre, including dynamite, blasting caps, fuse and the labor of making the holes and doing the blasting. In most cases the cost is recovered within the year, out of the increased yield, but in other cases where the increased yield would not be worth more than $\$ 15.00$ an acre, it is important to know how long this increased production is going to keep up so as to justify the expense.

Let us first consider the matter from a theoretical point of view.

One of the first uses of dynamite for subsoiling was in tree planting. Twenty-one years ago W. R. Gunnis planted an orchard with dynamite at $\mathrm{La}$ Mesa, $\mathrm{Cal}$. This orchard matured more rapidly than orchards set out with a spade, resisting drouth and other unfavorable conditions with marked success, and although the tract has been subdivided and used as a residence property, some of the trees are still thriving and for years this orchard was recognized as the most productive and best appearing in the neighborhood.

W. W. Stevens, Orchardist, Mayfield, Ga., planted trees with dynamite eighteen or twenty years ago. He says:

"They are the finest trees I have ever seen grow for their age. In the planting of peach trees I gained two years in six; in other words, I got as much fruit from a tree planted with dynamite at four years old as we usually get at six years old. I not only plant them with it, but where a tree is failing and seems to be on the decline, I start it off to growing again by firing charges from three to ten feet apart. Nothing seems to tickle the earth so much as planting watermelons after explosion of dynamite from three to four feet under ground."

Mr. James Craig, President of the Rose Cliff Farm, Waynesboro, Va., began planting trees with dynamite nine years ago. He writes under date November 15,1911 -

"I should think from the thoroughness of the work done by dynamite that it will last fifteen or twenty years without question."

Mr. Craig plants all his trees with dynamite.

Mr. Arthur E. Cole, Proprietor of High Point Farm, a small-fruit nursery at Chamblee, Ga., writes as follows under date of November $17,1911-$

"About eight years ago the New Roswell Road was graded. In the cut through the steep hill just south of Nancy Creek, between the eight and ninemile post (from Atlanta). much blasting was done. A vigorous growth of clover and young sycamore trees immediately sprang up on the roadside where this blasting was done. The clover seed found their own way from the hay where the mules were fed, into the porous soil where the dynamite was used. A good stand has appeared each succeeding year without any cultivation. Noticing this I began to observe rock quarries and other places where explosives had been used, and found similar conditions prevailing. Wherever the ground has been broken with dynamite a perfect system of subsoiling results. Cut a cake of butter with a sharp knife; the cut surface is left hard and smooth. Just so in s'sbsoiling with a plow. It rains, the water soaks through topsoil 
and then follows the course of the plow, soaking no further. But in subsoiling with dynamite exactly the opposite condition prevails. The ground is 'heaved,' shaken and broken many feet deep, and is left so open and porous that all the rainfall is absorbed and retained. This is given back as growing crops demand. Subsoiling with Du Pont Red Cross Dynamite has now become a common practice with farmers and orchardists. This process has the double advantage of irrigating and draining both at one time. Each place where a cartridge is discharged becomes an underground reservoir, and if thus broken in squares of ten to fourteen feet, with one-third to one-half stick of Red Cross 20 per cent., the ground will be sufficiently broken for drainage from hole to hole as a result. Perhaps the most valuable feature of subsoiling with dynamite is the lasting effects. Modern machinery can plow our ground very fast, but the work is not permanent, while in dynamited land the good effects are underneath and not affected by sun or wind and the porous condition remains for years. Of course the length of time varies with different soils and different crops and different modes of cultivation-limestone soil remaining open longest. Once the land is well subsoiled with dynamite and leguminous crops, peas, alfalfa, clover or rye are sown, thus feeding nitrogen deep into the soil from the air through the roots, a porous subsoil may be expected for from three to four years from one dynamiting. Of course it is not necessary to keep these particular crops growing continuously, but a good idea is to rotate, using one of them every second or third year. Last spring I dynamited some tree holes on my place, spaced about twenty-five feet. About mid-summer when everything was dry as a crisp from severe drought I decided to plant vegetables in the same rows with the young trees, between these dynamited holes. It was a test case and no cultivation was given, except one hoeing. The results were wonderful. I not only had vegetables, but they continued to bear till frost. It is evident that in the clay belt of middle Georgia, progressive farmers will all of them soon resort to subsoiling with dynamite. It is faster, more simple, less expensive and far less dangerous than often supposed to be. The public is invited to come at any time and see my apple trees, one year old, that have put on new growth of from five to seven feet in one year. They were planted last spring (consider the dry vear), in holes blasted with half stick of Du Pont Dynamite."

J. H. Baird, Supt. of the famous Hale Georgia Orchard Company, Fort Valley, Ga., operating the largest peach orchard in the world, writes under date of November 16, 1911.

"We have been subsoiling with dynamite for tree planting for three years; the results have been very satisfactory indeed. Just how long the benefit of breaking this hardpan will last is a problem. Our first dynamiting three years ago shows up splendidly on our trees and up to this time they are much in advance of those not dynamited. I should think at least one year. I believe the results in subsoiling in this manner will last eight to ten years, and it is my intention now to use dynamite in our old orchards at their very first appearance of 'going back.' I am sorry that I cannot give you more information on this line, but my experience with dynamite, as stated above, is only three years old. All agriculturists know that in order to get gieater yields the land has to be broken deeply and the new way of doing things is to cultivate less land and grow more per acre. Will certainly bring your product more in use each year." See also pages 87 and 97.

\section{Increased Wheat Yield $25 \%$}

Extract from letter of Mr. D. A. Beamer, manager, Missouri Immigration Association, Lamar, Mo., dated August 2, 1911 :

"The writer, on his own account, dynamited about three acres two years ago. The present season it carried a crop of wheat which was sown last fall. This three acres was part of a ten-acre field, and was decidedly the wettest and least productive part prior to the dynamiting.

"The wheat on this dynamited ground was treated exactly like the balance of the ten acres of which it is a part. and the wheat on the dynamited portion was at least 25 per cent. better than the balance on the ten-acre plot.

"As a result of my experience, I will subsoil ten acres of land this fall because the very first crop taken from the above three acres has shown a good profit on the cost of subsoiling." 


\section{Subsoiling a Success on I. H. C. Demonstration Farm}

International Harvester Company of America.

W. K. Wood, Manager.

W. A. Renn, Superintendent.

Brookhaven, Miss., September 11, 1912.

Du Pont Powder Co., Wilmington, Del.

Gentlemen.-As requested I am sending under separate cover four views, one each of cotton and corn, not subsoiled and one of each subsoiled.

You will note the great difference, and we will subsoil more extensively the coming year.

Yours truly,

W. A. RENN.

\section{Subsoiling a Success in Europe}

February 13, 1912.

I thought you might be interested to know that while a student at the Tokay Agricultural School at Tokay, Austria-Hungary, I subsoiled three acres of ground with dynamite prior to planting grape vines. The ground was in a very steep hillside and practically covered with shale rock. The dynamite broke up the ground and made it porous, and it is conservative to say that the vines planted in this way produced 50 per cent. more than those adjacent planted in the ordinary way.

Yours truly,

ALEX RICHTER, Highland, Arkansas.

\section{The Best Time to Subsoil}

Subsoiling with Red Cross Dynamite should be done only when the soil is dry-preferably immediately after harvest. Wheat or other cereal crops are usually harvested early in summer. The field may then be subsoiled under ideal conditions in July or August. Ground bearing corn, potatoes, hops, or other late maturing crops, should be subsoiled in September, October or November-as soon as the crop is off. Spring subsoiling is not advisable unless the soil is quite dry and when good rains may be expected soon after.

\section{Get What You Pay For}

The strength of all Du Pont dynamites is shown on the cartridges and cases with the exception of our Permissible Explosives and explosives having strengths of 20 per cent. or less. We guarantee the strength marking on cartridges and cases to be correct.

Anyone using dynamite the strength of which is not marked is probably getting less than the represented strength and is therefore paying too high a price for what he buys. Inferior goods, you know, can be sold at lower prices than standard manufactures. 


\section{HOW TO TRANSPORT,}

STORE, AND

- USE

\section{RED CROSS D Y N A M I T E}

DO NOT TRY TO

USE DYNAMITE

UNTIL YOU HAVE

CAREFULLY READ

THIS SECTION 


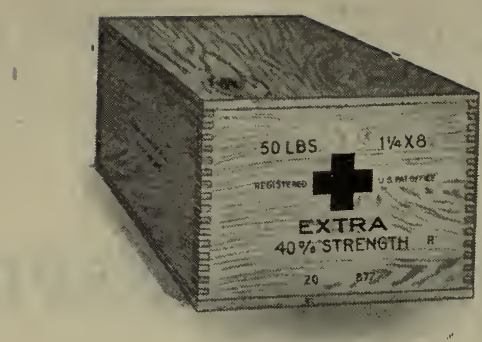

FIG. 83

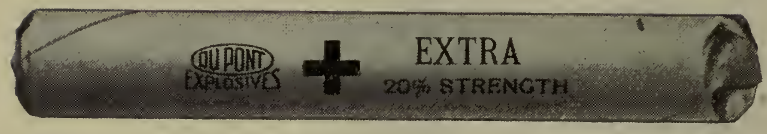

FIG. 84

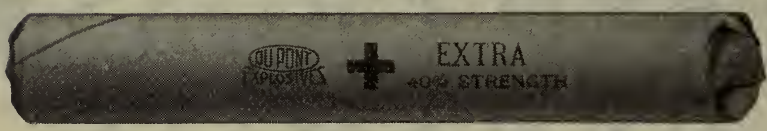

FIG. 85

TABLE SHOWING THE AGRICULTURAL WORK IN WHICH THE USE OF DYNAMITE WILL SAVE MONEY AND TIME, AND THE MOST SUITABLE BRAND AND STRENGTH OF DYNMITE FOR IT.

Kind of Work.

Brand and Strength of Explosive.

Boulder Blasting ........... Red Cross Extra Dynamite $40 \%$ to $60 \%$ strength Cellar and Foundation Ex-

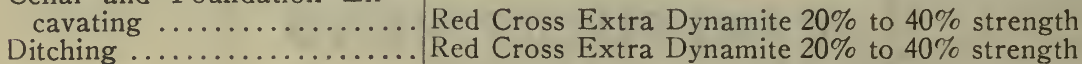

Fruit Tree Planting and Cultivating ................... Hardpan or Subsoil Blasting.. Log Splitting ..............

Log or Ice Jam Starting.... Red Cross Extra Dynamite $40 \%$ Pole or Post Hole Digging. . Red Cross Extra Dynamite $40 \%$ Road Grading ............... Red Cross Extra Dynamite 20\% to $40 \%$ Swamp Draining ............. Red Cross Extra Dynamite 40\% Stump Blasting $\ldots . . . \ldots \ldots \ldots . . .6$ Red Cross Extra Dynamite $40 \%$ Tree Felling ................. Red Cross Extra Dynamite 40\% Well Sinking ................. Red Cross Extra Dynamite 40\% Red Cross Extra Dynamite 20\% strength Red Cross Extra Dynamite $20 \%$ to $40 \%$ strength
Red Cross Extra Dynamite 20\% Du Pont Blasting Powder strength strength strength strength strength strength strength 


\section{Explosives}

Explosives are solids or liquids which can be changed almost instantaneously by a spark, great heat or powerful shock into gases having many times the volume of the explosive in its original form. Coal and wood are changed slowly into large volumes of gas by burning; water is changed into a large volume of gas (steam) by heating it. This is the whole theory of explosives and much in their use, which would otherwise seem difficult to explain, is easily understood if this theory be borne in mind.

Blasting explosives are divided into two classes, namely: High Explosives and Low Explosives. High Explosives are more commonly known as "dynamite," including all of those explosives which can be properly detonated only by means of an intermediate agent such as a blasting cap or electric fuze and not by simple ignition. Blasting powders are classified as low explosives and are exploded by a spark.

\section{Blasting Powder}

Blasting Powder is black and is produced in granulations or grains of various sizes. It is packed in bulk in steel kegs containing twenty-five pounds. Although it is invaluable for many kinds of coal mine, quarry and general excavating, it is not generally applicable to any blasting about the farm except for splitting logs as described on page 137.

\section{Dynamite}

Dynamite differs from blasting powder in that it detonates with much greater rapidity and has a greater shattering effect. The most important properties which contribute to the effect of dynamite are strength or disruptive power and quickness or shattering power. The other principal factors in the usefulness of dynamite are its stability or keeping qualities and such qualities as may tend to make it safer to handle. These essentials can only be secured and maintained by the employment of the highest quality of ingredients, greatest care and attention, expensive and complicated machinery, skillful labor and supervision, long experience, and continued tests. The Du Pont Company fulfills all of these requirements. It has been engaged in the explosive manufacturing business since 1802, has factories in all parts of the United States and no other manufacturing concern in this country maintains a greater number of technical chemists than are engaged at the Du Pont laboratories, who test daily the output of the factories to prevent deviation from standards, and constantly study and experiment with explosives in order to improve them.

Furthermore, a corps of experts in the use of explosives is maintained, not only to study the exact requirements of explosives in the various fields and differing conditions, but to demonstrate their qualities, action and method of using them.

The Du Pont Company manufactures numerous kinds of dynamite, each having some particular property which makes it different from any other kind. Almost every kind is made in different strengths. Some kinds will burn if a spark falls on them and all kinds can be burned if put in a fire. Don't, therefore, leave dynamite where it can be ignited any way, because, when hot it is very sensitive and often explodes. 


\section{Red Cross Dynamite, the Agricultural Explosive}

The Du Pont Company manufactures a special brand which is named "Red Cross .Extra Dynamite," and is especially adapted to farming purposes. It is a mixture of nitroglycerin and other explosives with an absorbent which renders the compound less sensitive to shock and more safely used and transported than ordinary dynamite.

Red Cross Dynamite explodes with great power, shattering or excavating anything which is in the immediate vicinity. Its general appearance and consistency is similar to damp sawdust, and it is placed on the market in paper-covered cartridges 8 inches long and of different diameters, the standard being $11 / 4$ inches. The cartridges are packed in cases containing 25 pounds or 50 pounds.

\section{Safe Handling of Dynamite}

There is a popular misconception of dynamite in the public mind. Newspapers in reporting outrages such as bomb throwing by anarchists, safe cracking "jobs" by burglars, etc., incorrectly report them as perpetrated with "Dynamite." The result is an erroneous, widespread impression that a dynamite cartridge will explode if dropped on the ground or thrown against the body of a person.

As a matter of fact, safe breakers and bomb throwers do not use dynamite cartridges at all; they would not be suitable for their purpose because it is so difficult to explode them. What these criminals use as a rule is nitro-glycerin. This dangerous explosive is used commercially for shooting oil wells, etc.

True there is a certain proportion of nitro-glycerin in dynamite cartridges, but the dangerous explosive is scientifically compounded with wood meal and some other ingredients in such a way that it can be absolutely depended upon not to explode accidentally if our simple and plain instructions for its use are complied with.

One of the safest of explosives manufactured by the $\mathrm{Du}$ Pont Powder Company is Red Cross Extra Dynamite, which is especially recommended for agricultural purposes. This brand of dynamite, in practice, is detonated by the powerful shock of an exploding blasting cap or electric fuze, the strongest cap or fuze being necessary because this dynamite is so insensitive.

Responsible people can use and handle dynamite just as safely as they can handle gasoline, matches, or coal oil. The energy of dynamite can be directed in the work to which it is adapted as well as the energy of steam can be directed in the work for which it is used.

\section{Prompt Removal From Freight Station}

The law requires prompt removal of all high explosives from freight stations. Hence farmers expecting shipment of dynamite or blasting caps should arrange with the freight agent or station master to notify them immediately on arrival of shipment, which should be removed within 24 hours. 


\section{Hauling}

When transporting explosives by team always keep the wagon boxes thoroughly swept out, and when using an open wagon protect the load from sparks, rain, etc., with a canvas covering. Store the cases of explosives so that they will not shift and never haul detonators and explosives together.

\section{Handling and Storing}

When dynamite is handled with bare hands, it nearly always causes a headache. Old gloves should therefore always be worn when using it, and they should be destroyed and clean ones provided, before they become damp and sticky. A pair of gloves will remain in good condition for a long time if the dynamite is handled carefully.

$\mathrm{Du}$ Pont Red Cross Dynamite is not so sensitive to shock that it is likely to explode from a slight jar. It is made just as insensitive as is practicable so that it is much safer to handle and use than ordinary dynamite, and this is why a strong detonator is necessary to explode it properly. Nevertheless it should be handled sensibly and carefully and only by responsible persons.

Dynamite and detonators should not be hauled together from the dealer's or the railroad station. The detonators do not weigh much, and can be brought along on some other trip. If blasting caps are purchased from a dealer in the tin boxes separate from the wooden shipping case, it is a good plan to put these boxes in a basket or wooden box with a horse blanket, coat, hay or anything else that would keep them from being roughly jarred and shaken on the way home. As soon as explosives are received they should be stored in a dry, properly ventilated building, which will not be likely to be set on fire or shot into, and far enough away from dwellings or roads to prevent loss of life if they were to be exploded accidentally. They should be kept under lock and key and where children or irresponsible persons cannot get at them. If large quantities are to be stored for some time, a dry, well-ventilated, fire-proof and bullet-proof magazine, located in an out of the way place should be provided. Fuse, wire, thawing kettles and blasting machines may be stored in the same building with the dynamite, but blasting caps and electric fuzes must never be stored in the same building, because they are more easily exploded than dynamite, and it would be possible to explode them accidentally by a hard shock or jar which would not explode dynamite. If detonators were to explode by themselves, they would be unlikely to do much damage unless there were a great many of them, but if they were to explode in the same room with dynamite, they would probably cause the dynamite to explode too, and this might do very serious damage. 


\section{Opening Cases}

When ready to use the dynamite, open the box or case with a hardwood wedge and a mallet, and take to the work, in a dry box or pail, the number of cartridges required immediately. Never take more than the day's supply even in warm weather, and in cold weather, take only what can be kept thawed until it is to be used, unless there are arrangements for keeping it thawed where the blasting is to be done. Let somebody else carry the tamping stick, fuse, and detonators, to the work. As soon as holes are ready for the dynamite-and when possible the holes should all be ready before the dynamite is brought to the work-the priming, charging, tamping and firing should be carried on as rapidly as possible without becoming careless.

A very little practice will put you in the way of doing blasting quickly, systematically and economically, and you will wonder how you ever got along without dynamite.

\section{Thawing}

Some kinds of dynamite freeze at about 50 degrees Fahrenheit and will not explode at all, or only imperfectly, when in that condition. Even when chilled they cannot be depended on to work well. Red Cross Dynamite is an exception to this rule, for it will not freeze until the weather is quite cold. When dynamite is frozen it must be thawed, or if chilled it must be warmed before using. Frozen dynamite is easily recognized because it is hard and rigid.

If, after the thawed dynamite is ready to use, something causes a delay and it becomes chilled or frozen before it can be put into the borehole, it should be thawed or warmed again. It does not harm dynamite to thaw it many times, provided this is done in the right way.

Red Cross Dynamite, if loaded in the ground below the frost line and properly tamped, will not freeze again, but other dynamite may chill or freeze almost immediately when loaded in cold ground, which makes it necessary to detonate it immediately after charging. It is this that makes Red Cross Dynamite so valuable in cold weather.

The best way to thaw dynamite, and to keep it thawed until it is to be used, is in a thawing kettle made for the purpose. Dynamite may be thawed by leaving it spread out on a shelf in a warm room (not in a dwelling) over night, or by burying it, while in the case, in manure. It may also be thawed by putting it in a covered, water-tight pail and hanging this pail in warm water and it may be carried to the work in any kind of dry bucket or box if covered with an old coat, a piece of blanket or something of the kind to keep it warm. It is exceedingly dangerous to try to thaw dynamite in front of an open fire, or in hot sand, or on hot stones, or metal or steam pipes, or in an oven, and it is in attempting to thaw dynamite in some of these ways that accidents frequently happen. Do not attempt to thaw dynamite by putting the cartridges in hot water or by turning a jet of steam on it. 
The Catasauqua Thawing Kettle is made in one piece with an outside jacket for the hot water all around the dynamite section. The No. 1 size holds 30 pounds of dynamite and the No. 2 size 60 pounds.

The water must never be heated in the Catasauqua Kettle, but must be heated in some other vessel, and when not too hot to burn the hand, poured into the water compartment provided the dynamite compartment is empty. It is dangerous to heat the water in the Catasauqua Kettle even when the dynamite section is empty, because there may be a little nitroglycerin in it which has soaked out of the dynamite previously thawed. Dynamite should not be put into the thawing kettles without first carefully wiping out the dynamite compartment clean and dry.

Do not place a thawing kettle over a fire while it contains dynamite.

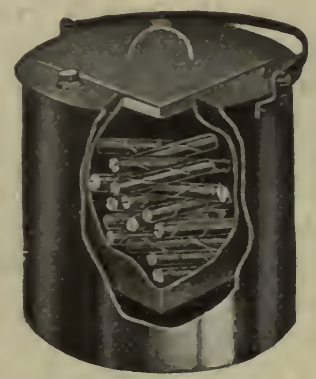

Fig. 86.-CATASAUQUA THAWING KeTtLE

\section{Du Pont Blasting Caps}

Du Pont Blasting Caps are made in several different strengths, but nothing weaker than the No. 6 (red label) strength should be used, because:

They insure complete detonation.

They increase the execution of the explosive.

They offset to some extent deterioration, due to improper storage.

They prevent the loss of the charge by burning.

Blasting caps are put up in boxes of 100 and from 5 to 50 boxes are packed for shipment in wooden cases. They may be exploded by shock, heat or sparks, so must be kept away from fire. They are weakened by moisture and therefore must be stored in a dry, cool place. 


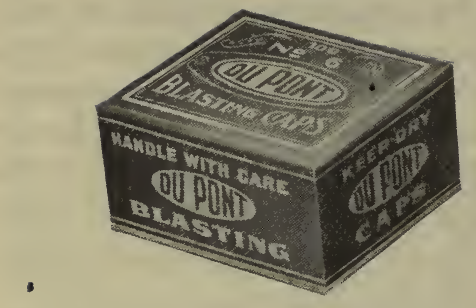

FIG. 87.-DU PONT NO. 6 BI.ASTING CAPS

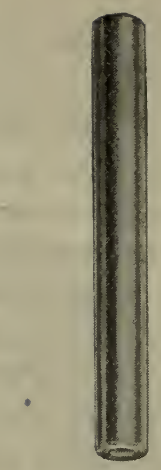

FIG. 88

When handling blasting caps great care should be exercised as they are much more sensitive than dynamite. Therefore, do not under any circumstances carry them together with dynamite, or loose in your pocket. Keep then away from children or irresponsible people, and do not attempt to investigate their contents by tapping, picking or scraping. In withdrawing them from the box do not use wire, nails or any other sharp instruments as the friction might cause them to explode. A good way to withdraw a cap from the box is to place the cover over all but one of the caps, then invert the box over your hand, when the uncovered cap will fall into the hand. When inserting fuse before crimping, do not rotate the fuse as the end may scratch the fulminate charge of the cap and explode it.

\section{Fuse}

Powder wrapped in jute and cotton yarn and sometimes in tape. Many kinds are made, but either the Crescent or Beaver grades are satisfactory for most work about the farm.

Sometimes, especially in windy weather, it is difficult to light fuse because the powder in the outer end may have become damp or a little of it may have spilled out. When this occurs it is well to cut off an inch or so, in order that the powder will be dry. A half inch of the outer end of the fuse should be split with a sharp knife and spread out so that it can be easily lighted in windy weather by pushing the burning end of the match against the fuse immediately after the match has been struck.

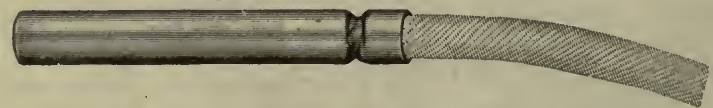

FIG. 89.-BLASTING CAP CRIMPED TO FUSE

Fuse should always be kept dry and should be stored in a cool, dry place. If stored in a damp place it becomes damaged after a time and many fail to burn through. If stored in a hot, poorly ventilated place, as for example, close under the roof of a small shed in summer time, it may be damaged either by becoming soft and oily or by drying out and becoming so hard and brittle that it will break when unrolled. Fuse also may become stiff and brittle in cold weather and when in this condition should be warmed before being unrolled. 
Fuse is put up in a double roll, one fitting inside the other each 50 feet long. Each double roll of 100 feet is wrapped separately. It is packed for shipment in wooden cases containing from 500 to 6,000 feet and in barrels containing 8,000 to 12,000 feet.

\section{Dupont Cap Crimpers}

Du Pont Cap Crimpers are necessary wherever blasting is done with fuse and blasting caps. Without a cap crimper it is impossible to attach the blasting cap securely or safely to the fuse. The Du Pont Cap Crimper has in

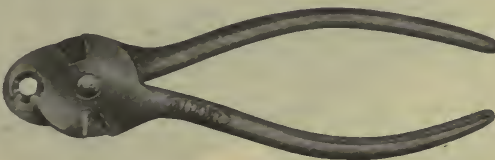

FIG. 90.-DU PONT CAP CRIMPER addition to the crimping jaws, which make a water-tight crimp, two shears for cutting fuse and a straight arm to make the hole in the cartridge for the insertion of the blasting cap.

\section{Victor Electric Fuzes}

Victor Electric Fuzes are made in three strengths-Nos. 6, 7 and 8with two copper wires 4 feet, 6 feet, 8 feet and so on up to 30 feet in length. For work on the farm the No. 6 strength is sufficient. Victor Electric Fuzes, like blasting caps, can be exploded by shock or heat, and therefore must be handled in exactly the same way. The same precautions regarding storage and handling as given for blasting caps should be strictly observed. Never attempt to pull the wires out of their setting or investigate the contents of Victor Electric Fuzes.

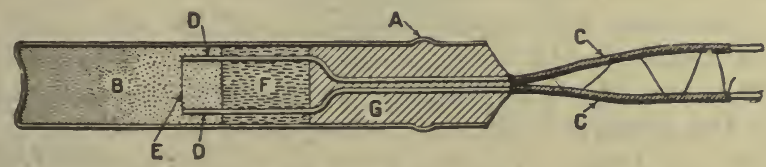

FIG. 91.-ELECTRIC FUZE CROSS SECTION

" $\mathrm{A}$ " is the shell of copper, having a corrugation thrown out from the inside, which holds the filling material more firmly in place; " $\mathrm{B}$ " is the chamber containing the explosive charge; "C" the insulated copper wires entering the cap; "D" the bare ends of the copper wires projecting through the plug into the charge; " $\mathrm{E}$ " the small platinum wire or "bridge" soldered to and connecting the two ends of the copper wires, which is heated by the electric current; " $F$ " the composition plug holding the fuze wires firmly in place; "G" the filling material.

Electric fuzes have two insulated copper wires sealed in the cap. The tips of these wires inside of the cap are bare and joined together by a platinum wire finer than a thread. When the electric current passes through the electric fuze it makes the platinum wire hot enough to detonate the explosive in the copper cap.

Besides the advantageous properties of the No. 6 Blasting Caps, as enumerated, No. 6 Victor Electric Fuzes reduce the chances of misfires, save time, eliminate delayed or premature explosions and in a good many instances, such as in stump blasting, save dynamite. 

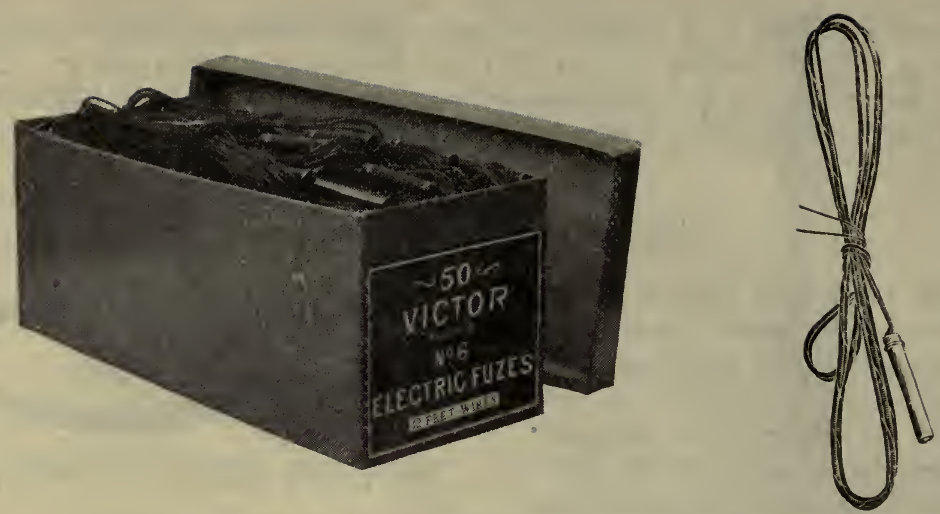

FIG. 92.-VICTOR NO. 6 (RED LABEL) ELECTRIC FUZES

\section{Reliable Blasting Machines}

Reliable Blasting Machines are made in three sizes. The No. 2 will detonate from one to ten Electric Fuzes; the No. 3 will detonate from one to thirty Electric Fuzes, and the No. 4 will detonate from one to fifty Electric Fuzes when all of the Electric Fuzes are connected in series. The Blasting Machine is operated by lifting the handle of the rack bar as far as possible and then pushing it down with a constant hard, quick blow. When the rack bar strikes the bottom of the Blasting Machine the current of electricity passes through the wires and detonates the Electric Fuzes. It is well to always place the Blasting Machine upon something firm, level and dry when operating it.

Reliable No. 2 Blasting Machines have two binding posts and the No. 3 size also has two posts unless specially ordered with three. Threepost Blasting Machines will explode at one time $50 \%$ more Electric Fuzes than two-post Blasting Machines of the same size. The leading wires are connected to the Blasting Machine by pushing the well-scraped bare ends through the small hole in the binding posts and screwing the wing nut down firmly on them. When a three-post Blasting Machine is used with three leading wires, the ones from the two outside posts are connected to the first and the last Electric Fuzes in the circuit, and the one from the middle post is connected between the two middle Electric Fuzes in the circuit. A three-post Blasting Machine may be used with two wires only by connecting these wires to the middle and either one of the outside binding posts-not the two outside ones. Reliable Blasting Machines, if properly used, will wear for many years. They must be kept out of the wet and mud and must not be thrown about carelessly. If it is necessary to use them in wet weather or on wet work, they should be carefully wiped off before putting them away. A Blasting Machine should not be put in a hot place to dry out if it has become wet, but after being wiped off should be put away in a cool, dry place until it has had time to dry out slowly.

Blasting Machines should be tested occasionally with a Du Pont Rheostat to be sure that they are up to standard capacity. A description of the Rheostat and instructions for using it will be forwarded on application. 

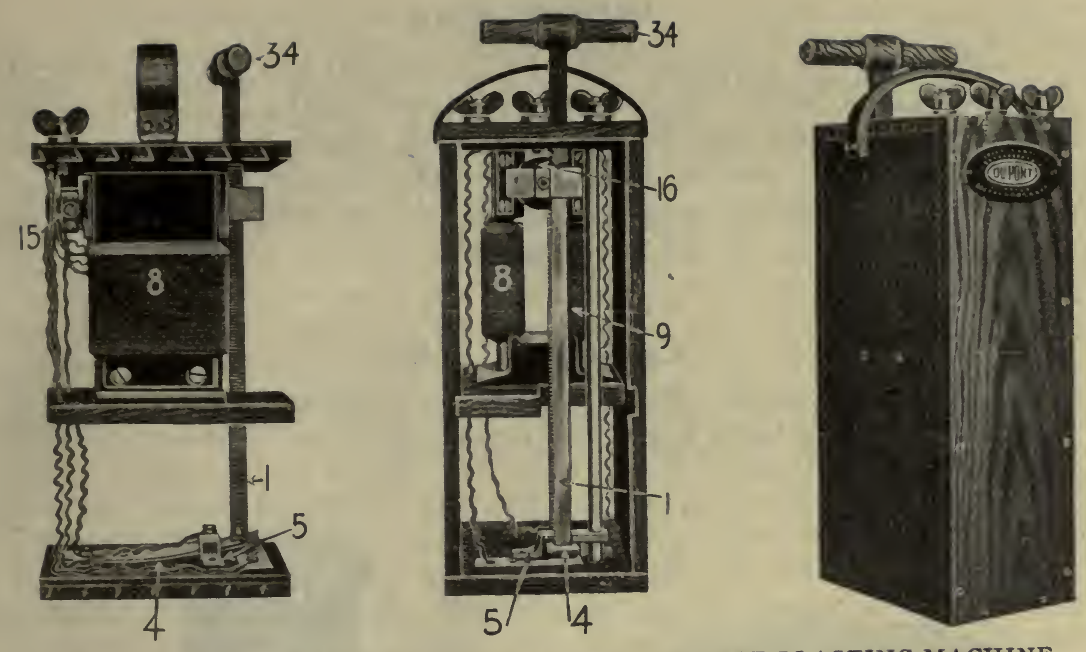

FIG. 93.-INTERIOR AND EXTERIOR VIEWS OF 3-POST BLASTING MACHINE

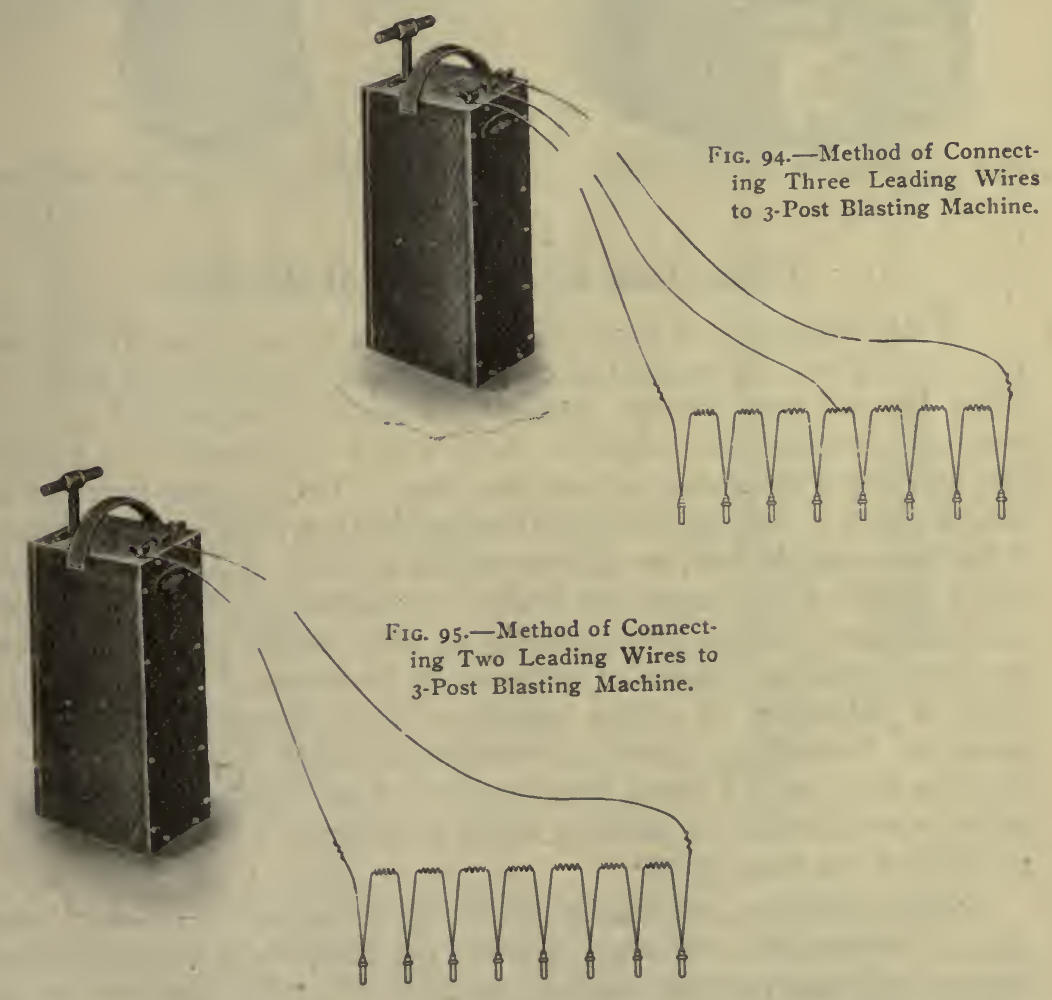

Series connection with blasting machine. The break in the wires is merely to indicate that any required length of wire may be used between electric fuzes and blasting machine. There must be no break in the actual circuit. 


\section{Leading; Wire}

Leading Wire is sold in coils of 200 feet, 250 feet, 300 feet and 500 feet. There are two kinds, Single and Duplex. In the Duplex Wire, the two wires are bound together, which usually makes it more convenient to handle. Single Leading Wire weighs about two pounds to the hundred feet, and Duplex Leading Wire weighs four pounds to the hundred feet. Leading Wire is sold by the pound.

\section{Connecting Wire}

Connecting Wire is sold in 1-1b. and 2-1b. spools. A 1-1b. spool of No. 20 Connecting Wire holds about 210 feet.

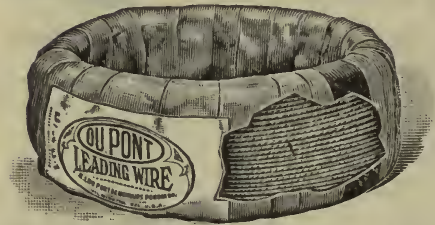

FIG. 96.-COIL OF LEADING WIRE

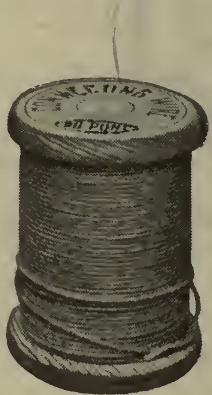

FIG. 97.-SPOOL OF CONNECTING WIRE

\section{Tools Used in Agricultural Blasting}

Tools necessary in farm blasting are to be found on almost every farm or can be easily made there or at the nearest blacksmith shop. The holes for blasting stumps, boulders, trees, ditches, post holes, road grading, trenches, etc., can all be made with a crowbar having a point at one end and a flat chisel edge at the other. The wooden tamping stick can be made in half an hour by dressing down a hard wood sapling, or, if the holes are shallow, an old broomstick will do. A long handle shovel and a grub-hoe or mattock are always serviceable when blasting stumps and boulders. Although a crowbar is very satisfactory for making a moderate number of holes, it will usually be found of advantage, if the work is extensive, to secure augers or bars especially made for the purpose. Sometimes a steel rod one-quarter of an inch in diameter and five feet long with a sharp slender point at one end and a ring on the other is serviceable for probing under a stump to find out the size and position of the main roots.

When draining swamps by shattering the impervious subsoil under them it is sometimes necessary to make the holes for the dynamite much deeper than can be done with a crowbar. For this work rod or pipe extensions for the augers are used. In subsoiling, a bar a little heavier and shorter than a crowbar is also used. This subsoil bar can be removed when it becomes fast by means of a trace chain and a lever. 
Below we illustrate a punch-bar which can be made by any blacksmith in a very short time. All the materials required are nine feet of ordinary water piping $11 / 4$ in. inside diam., one $11 / 4$ in. tee, one $11 / 4$ in. coupling, and nine inches of $11 / 2$ in. round steel. The pipe should be cut into two lengths $3 \mathrm{r} / 2$ feet each and two lengths 12 inches each. The 9 in. piece of steel should be inserted into one of the $3 \mathrm{r} / 2 \mathrm{ft}$. lengths, about 3 inches, and welded, it should then be pointed pin shape. The remaining parts should be put together as per illustrations.

This tool can be very successfully used for putting down subsoil, tree planting, ditching, and, with extensions, deep drainage holes. The method of working with it is to start the hole in exactly the same manner as when a crowbar is used. After the hole is some 6 or 8 inches deep a little water should be poured into it. The drill is then placed in the hole and by working it up and down a three-foot hole can be put down in less than one minute. Holes of any depth and at any angle can be put down without difficulty. When putting down deep holes, extensions have to be added. It is especially adapted for placing holes under stumps or boulders as it will work around the small roots of stumps, and push aside small stones or pebbles around and under boulders. The use of the water facilitates its penetrating power and prevents jamming.

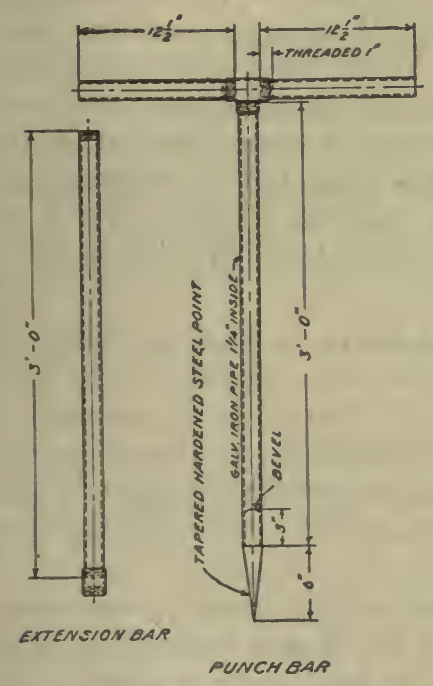

FIG. 98.-PUGH PUNCH BAR AND EXTENSION

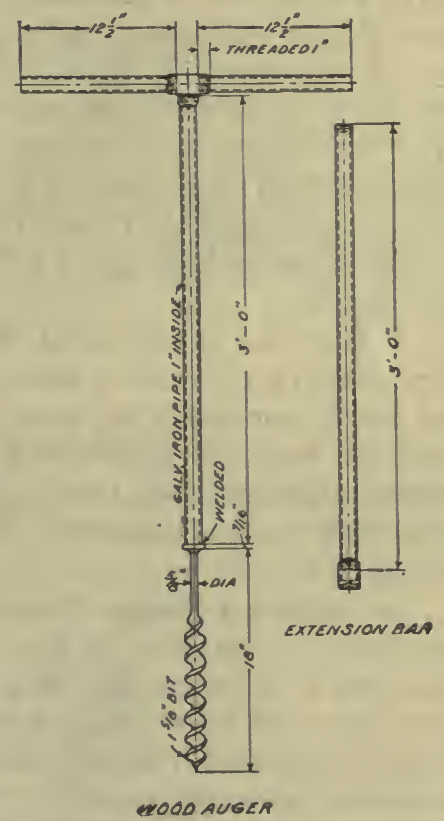

liIG. 99.-PUGH WOOD AUGER AND EXTENSION

These tools may be obtained of any hardware dealer or direct from Job. T. Pugh, 31 st and Ludlow Sts., Philadelphia, Pa., at these prices: F. O. B. Philadelphia, Punch Bar, \$2.40; Wood Auger, $\$ 2.60 ; 3$-ft. Extensions, 50 cents each. Local prices will run higher to cover freight charges. These tools are made on specifications of the Du Pont Company, and will be all that the average blaster will need for making bore holes in earth or wood. 
FIG. I0o.-STEEL SUBSOIL BAR

Useful for making holes in shale or very tough hardpan. It can be made by any blacksmith from $11 / 2$ steel. It is driven in by means of a 16-pound matul. If it sticks, it may be withdrawn by looping a stout chain a few times around it near the ground, and prying it with a rail or crowbar passed through the loop of the chain.

\section{Principles of Blasting}

When dynamite explodes, that is, when the small mass of dynamite is changed into a very large volume of hot gases, these gases exert a strong pushing force equally in every direction because they require a much larger space than the dynamite which produced them. If the dynamite is shut up in a space just large enough to hold it, that is, if it is closely confined before it is exploded, the gases in escaping to the open force out and carry along with them the material which shuts them in.

These gases, pressing equally in every direction, will escape principally where there is the least pressure to hold them in, that is, along the lines of least resistance, and will force out the material confining them more in that direction than in any other. If the back pressure holding them in is about the same over the top and on all sides, then they will carry with them, or break up as they escape, a large amount of the material which shuts them in, but if one place in the earth or rock around them is much weaker than all of the rest then the pressure will force through there and the gases will escape without doing as much work as they should.

It must be remembered then that in order to have a charge of dynamite do good work it must be so placed that the holding-in pressure is as nearly as possible the same on top and all sides of it. If a charge of dynamite explodes properly the change into gases is almost instantaneous, although some time is always required and some kinds of dynamite explode-or "detonate" as it is often called-more rapidly than others.

Sometimes a charge of dynamite explodes imperfectly or may even burn partly or entirely. When only part of the charge explodes so little work may be accomplished that it will have to be done over again. The gases given off by burning dynamite are quite different from those of properly exploded dynamite and are often very poisonous. Imperfect detonation is usually caused by the use of weak detonators or dynamite that is insensitive because of being frozen or chilled.

Chilled or frozen dynamite will rarely do good work. The other principal causes of poor results in blasting are insufficient tamping or the improper location of the charge. Poor results may also be due to too large or too small a charge or to the use of the wrong strength or wrong kind of dynamite. 
Dynamite is exploded by a detonator. There are two styles of detonators, one known as a blasting cap and the other as an electric fuze (pronounced fu-zee). Both are small copper cylinders about a quarter of an inch in diameter and from one and a half to two and one-eighth inches long, which contain a small quantity of a very powerful explosive. This explosive is quite sensitive to heat and shock and a hard, sharp blow may explode it, so detonators must be carefully handled.

The heat to detonate a blasting cap is provided by the spark from a piece of fuse, one end of which has been pushed into the open end of the blasting cap, and fastened there by crimping the blasting cap on it with a cap crimper. When the other end of the fuse is lighted it burns through slowly and when the fire reaches it the blasting cap explodes.

Nothing weaker than the No. 6 (red label) Blasting Cap or Electric Fuze can be depended on to properly explode dynamite.

When more than one charge of dynamite is to be exploded at the same instant, the blasting must be done electrically. If the charges are too far apart for the wire of one electric fuze to be connected directly to that of the next one, it is necessary to use connecting wire to join them.

The electric current for detonating electric fuzes is produced by the blasting machine and is carried to the electric fuzes through leading wire.

\section{Method of Exploding Dynamite}

The detonator, to do its work properly, must be closely surrounded by the dynamite, because air in the open space between the detonator and the dynamite acts as a cushion when the detonator explodes and lessens the shock to the dynamite. This may result in an imperfect explosion of the dynamite with but little work done. When the charge of dynamite is all pressed together in a mass one detonator is sufficient to explode it. If it is strung out for fifteen or twenty feet in a deep bore hole it is generally best to use two detonators.

\section{Preparing Caps and Fuse}

Placing the detonator in the cartridge of dynamite is called priming it, and the cartridge with the detonator in it is called the primer cartridge or primer. When the charge consists of more than one cartridge the primer should generally be loaded last or next to last.

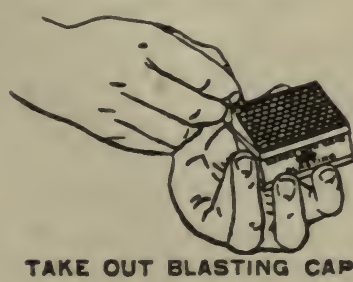

FIG. 101

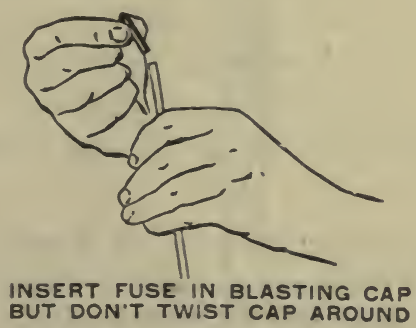

FIG. 102 


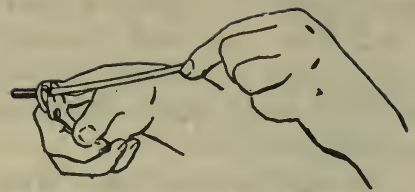

CRIMP THE BLASTING CAP TO FUSE SECURELY WITH DU PONT
CAP CRIMPER

FIG. 103

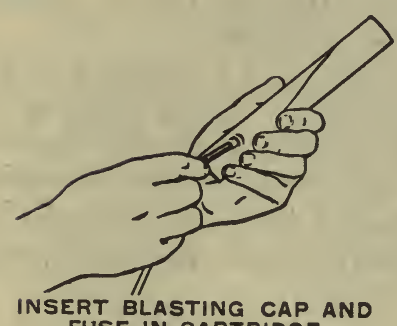

FUSE IN CARTRIDGE

FIG. 105

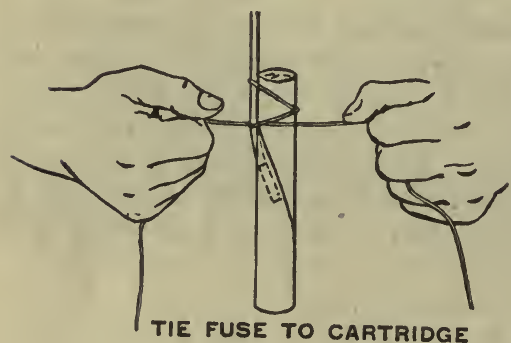

FIG. 107

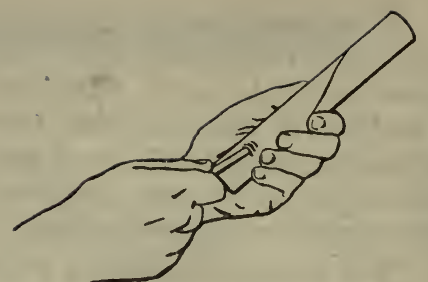

PUNCH HOLE IN SIDE OF CARTRIDGE WITH ROUND POINTED HANDLE OF CAP CRIMPER

FIG. 104

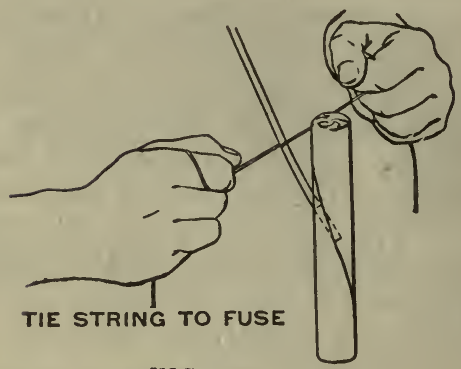

FIG. 106

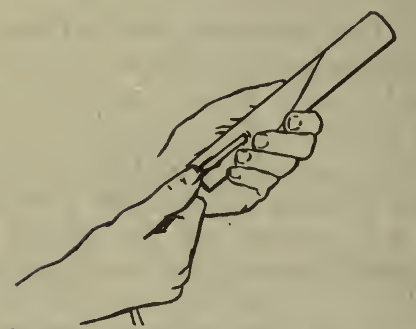

FASTEN FUSE TO CARTRIDGE BY PUNCHING A HAIRPIN THROUGH CARTRIDGE ON BOTH SIDES OF FUSE

FIG. 108

\section{HOW TO PRIME}

A DYNAMITE,

CARTRIDGE

FOLLOW THESE,

DIRECTIONS

C.AREFULLY

BEND HAIRPIN POINTS UP

FIG. 109 
The FIRST STEP in the preparation of the primer, when using fuse and blasting cap, is to examine your dynamite and see that it is not frozen. Frozen dynamite is hard and rigid; when thawed it is soft. Next examine your fuse, see that it is not stiff and brittle; in this condition it is advisable to warm same slightly before a fire until it becomes pliable. Take your cap crimpers and cut the required length from the roll; cut should be made squarely across and not diagonally. Sometimes in the cutting the end becomes flattened, thereby making the end of the fuse too large to enter the blasting cap. It is therefore advisable to squeeze the end round with index finger and thumb. Insert this end carefully into the detonator, well down to the explosive charge. Do not twist it about. The charge is very sensitive and the friction caused may explode it. Although this operation is not dangerous, yet great care should be exercised. After the fuse is inserted into the detonator as above described, take the cap crimper and crimp detonator to the fuse. The crimp should be made near the end which the fuse enters, so as not to disturb in any way the explosive charge which the blasting cap contains. Do not use common pincers, knife, or the teeth in this operation. If the work is wet, then smear the joint with tallow, wax or soap. Do not use oily grease as the oil might penetrate the fuse wrapping and spoil the powder.

The next operation is the insertion of the cap into the dynamite cartridge. There are two methods of doing this, namely: (1) By punching a hole diagonally into the side of cartridge, insert blasting cap into same and tie fuse with a piece of twine to side of cartridge. Electric fuzes may be inserted and fastened in the same manner. Another quick method of fastening fuse-but not electric fuze wires-is to straddle the fuse with an ordinary soft iron wire hairpin, pushing the legs of same right through the cartridge and bending them upward on the opposite side. Do not use steel wire hairpins and do not use this method to fasten electric fuze wires as it may short-circuit them and cause a misfire. If only a half cartridge is required for a charge, each end of the whole cartridge should be primed as described above before cutting it in half, as by doing this lose of dynamite from spilling is obviated-do not cut, break, or punch a hole into frozen dynamite cartridges; or (2) by unfolding paper wrapper at one end of cartridge and punching a hole about $1 \frac{1}{2}$ inches deep with the rounded handle of the cap crimper. Into this insert the cap with fuse, draw paper wrapper over and tie same tight with a piece of twine.

Method No. 1 is preferred by most agricultural blasters because it leaves the whole top of the cartridge intact for tamping, and also leaves a cushion of dynamite between the tamping stick and the detonator, making the operation of tamping easier and safer. 


\section{Charging}

Having primed the cartridge in the manner described, insert it in the borehole on top or next to top of the rest of the charge if more than one cartridge is used and push it carefully home. Putting the explosive into the borehole is called charging or loading the borehole. It is generally best in dry ground to slit the paper shells lengthwise in two or three places with a sharp knife before putting the cartridge into the borehole, as a slit cartridge will spread out in the borehole better. The primer should not be slit. Push the cartridges, except the primer cartridge, firmly into place with a wooden stick so that they will expand and fill up their part of the hole, for crevices or air spaces may lessen the power of an explosive. Expanded cartridges also occupy less of the length of the borehole and make possible a heavy charge at bottom of hole. The primer is loaded last, or next to last, and is pushed down only hard enough to touch the preceding cartridge. Each cartridge must touch the one previously loaded, for if any space between the cartridge occurs through falling dirt or stones, or through the sticking of a cartridge in the borehole, a part of the charge may fail to explode.

Never force a primer into a borehole, because the detonator which it contains is sensitive to shock and might explode if too much force is used.

\section{Tamping}

After the charge is pressed home, as directed, put in two or three inches of fine dirt or damp sand, and with a wooden stick press it gently on top of the dynamite. Then fill up two or three inches more of the hole, packing it in a little more firmly. After five or six inches covers the charge, it may be pressed firmly into place without danger of premature explosion. The tamping material should be packed as firmly on top of the charge as can be done without moving the electric fuze or blasting cap in the primer, but it is not safe to tamp by a blow any stronger than can be given by hand. Fill the borehole up with 'tamping until even with the surface. The firmer and harder the tamping can be made (without overlooking the above precautions) the better will be the results. If the borehole is not properly tamped, the charge is likely to "blow out," or at any rate some of its force will be wasted.

Do not use iron or steel bars or tools for tamping because the metal tools may detonate the explosives. Use only a wooden tamping stick with no metal parts. 


\section{Firing}

Exploding the charge is called firing and can be done either by caps and fuse or electrically by electric fuzes and blasting machine. When cap and fuse are used cut the fuse long enough to enable you to retire to a safe distance. Fuse burns on an average of two feet per minute and on page 140 is a table showing the line of safety to be observed for various classes of blasting, as also the amount of fuse required to enable the blaster to reach same.

Never light the fuse or operate the blasting machine until you have warned everyone near that you are about to fire, and until you are thoroughly satisfied that there is no one sufficiently near to be injured by the material thrown into the air by the blast.

Never investigate a misfire immediately. It sometimes happens that the charge does not explode exactly when it should but does so a little later. This rarely if ever occurs when firing electrically, but is not so infrequent when fuse is used, because careless tamping sometimes tears or abrades the fuse so that it will burn very slowly. A misfire with fuse should not be investigated for at least one-half hour, but it is much better to wait a full hour. When firing electrically be sure that all your connections are $\mathrm{OK}$ and do not connect the leading wire to the blasting machine until everything else is ready for the blast. This will prevent some inexperienced person from accidentally operating the blasting machine and exploding the charge before the blaster has had time to reach the safety line.

\section{What To Do in Case of Misfire}

Never try to dig out the old charge. Make, charge and prime a new borehole far enough from the first to make sure the tools will not touch the first charge.

Always fire just as soon as possible after tamping. In fact priming, charging, tamping and firing should be done as quickly as it is possible to do them thoroughly, because wet or even damp ground may injure the dynamite or even the detonator to some extent and in cold weather dynamite may become chilled or frozen which makes it insensitive. When viewing a blast it is always advisable to look out carefully for falling material which may be thrown farther than anticipated and a position should always be taken so that the sun and wind will be at your back. In any case the sun should not be faced, as in doing so it is naturally difficult to discern material flying through the air. Look up in the air, rather than at the stump or boulder being blasted. 


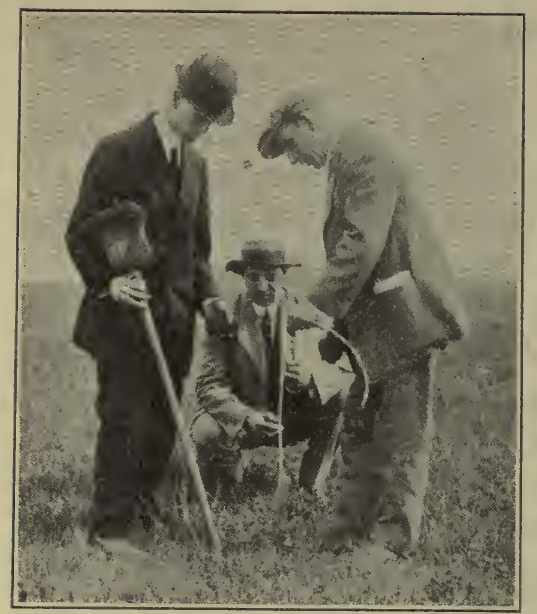

FIG. III

Lowering Primed Cartridge Into Hole

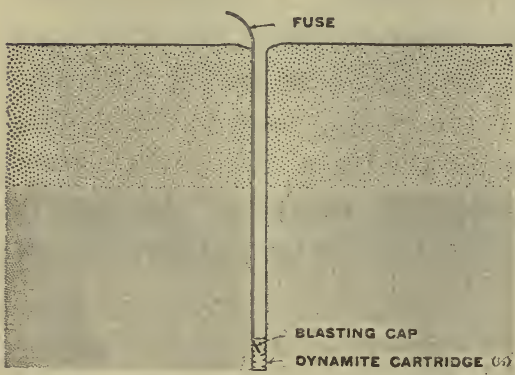

PRESS CARTRIDGE DOWN GENTLY: DON'T POUND

FIG. 113

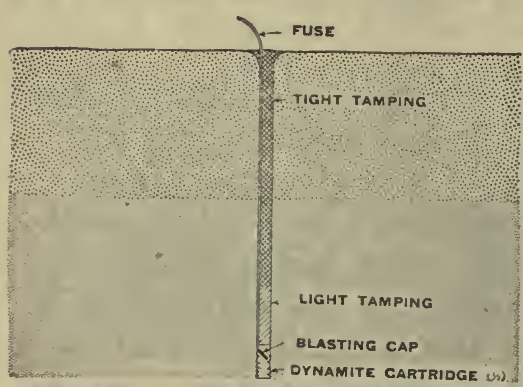

TAMP FIRMLY TO THE TOP AND IT IS READY TO FIRE

FIG. 115

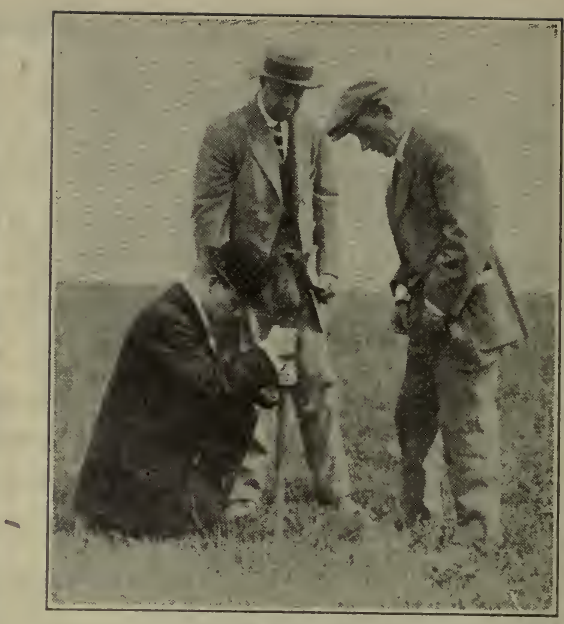

FIG. II 2

TAMPINg With Broom-Stick

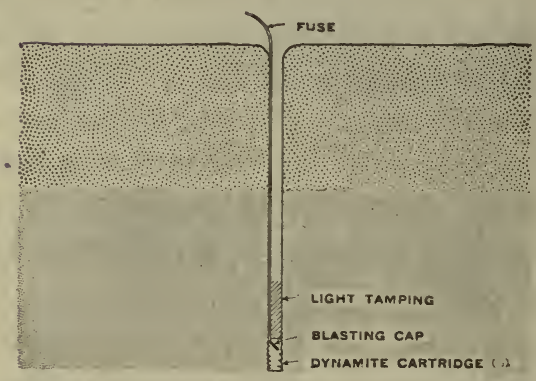

PUT IN 6 TOIO INCHES OF EARTH AND TAMP LIGHTLY

FIG. 114

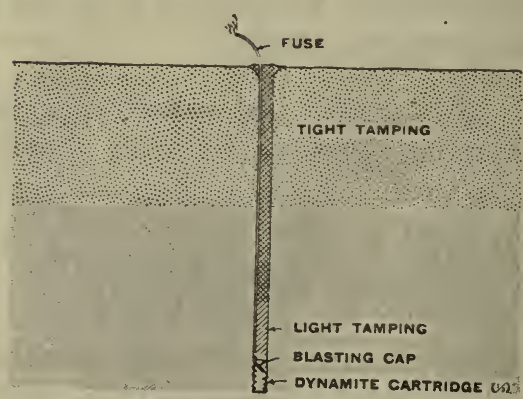

LIGHT FUSE AND RETIRE TO A SAFE DISTANCE

FIG. 116 


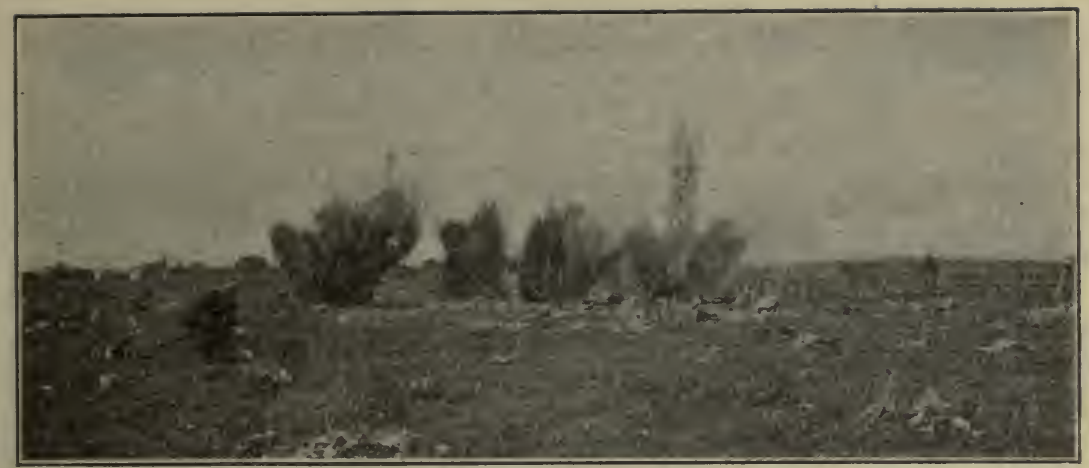

FIG. 117.-BLASTING STUMPS ELECTRICALLY

\section{Blasting by Electricity}

Large boulders and large stumps with spreading roots can often be blown out and broken up more thoroughly and with less dynamite if it is distributed in several charges in different places under the boulder or stump and all of these charges exploded at one time. Groups of stumps standing close together can also be blasted in this way. In order to dig a ditch satisfactorily it is always necessary to explode a number of charges simultaneously. In well sinking and other kinds of blasting it is of advantage to explode a number of charges at one time, as each tends to help the other. The only way in which several charges some distance apart can be exploded at exactly the same time is by the electric method of blasting. Electric blasting may, of course, if so desired, be applied to all of the work described in this Handbook, but it is generally unnecessary and more expensive, except in the blasting just described.

The equipment for blasting by electricity, in addition to dynamite, consists of
Electric Fuzes
Leading Wire
Connecting Wire
Blasting Machine

When the charges of dynamite have been primed with electric fuzes and tamped as already described, the two electric fuze wires extend from the ground over each charge. These two wires should be separated and one of them connected to one of the wires of the next electric fuze on one side and the other one should be connected in the same way to one of the wires of the electric fuze in the hole on the other side. This should be continued until all of the charges are connected in a row with one free wire extending from the first charge and another extending from the last charge. This is called "connecting in series." If the holes are too far apart for the electric fuze wires to reach between them, pieces of connecting wire will have to be used to connect the electric fuze wires in adjoining charges. 
Connections are all made by twisting bare wire ends securely together. All wire ends should be scraped with an old knife so that they will be free from grease or corrosion when connections are made.

All bare joints or other uncovered places in the wire must be kept away from water or damp ground. This can be accomplished by putting a stick, block of wood or stone under the wire on each side of the bare place.

The Du Pont Company manufactures an instrument for testing blasting circuits, called the Du Pont Galvanometer. This is a very ingenious and useful instrument where much blasting is done by electricity, and saves much time in locating breaks in electric circuits. For instructions as to its use ask for Galvanometer Booklet.

\section{Instructions for Agricultural Blasting}

In the following pages it is our endeavor to give as nearly as possible definite instructions as to the various methods employed to do different kinds of blasting about the farm. Due to the diversity of local conditions, such as nature of soil, thickness and quality of the subsoil or hardpan, the root system of trees, position and grain of boulders, etc., it can be readily understood that it is practically an impossibility to be able to outline any precise method of procedure, that will fit every case, and accordingly it may be found of advantage to vary from the instructions relative to the charge of explosives to be used. Nevertheless if they are fully followed in a general way, but little experience will enable the operator to do the work even more quickly and economically than when first he attempts it.

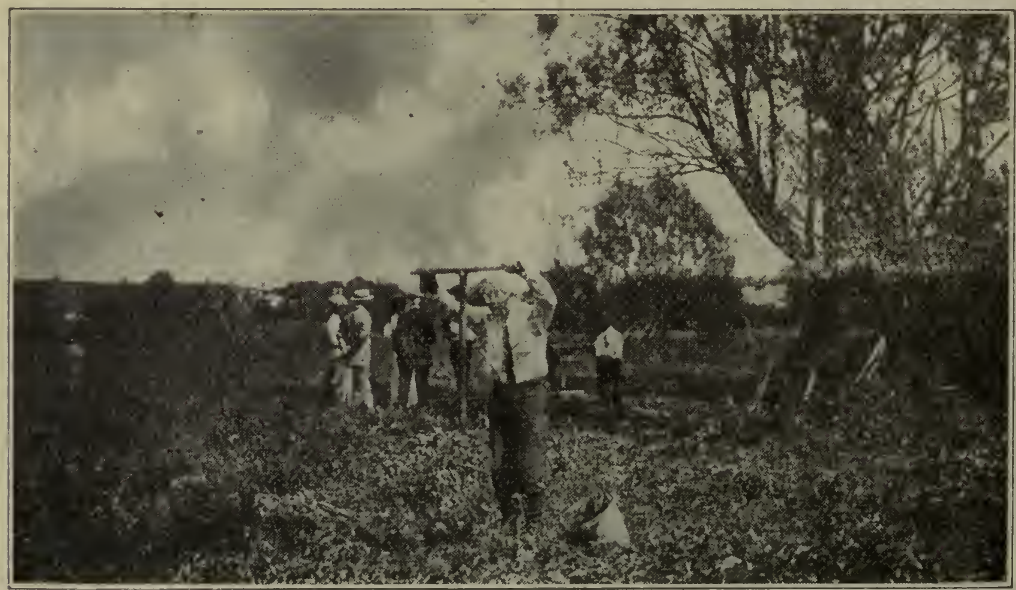

FIG. II8A.-MAKING HOLES WITH PUNCH BAR 


\section{Blasting Stumps}

"Root systems of the different forest trees are stibject to a considerable number of variations, due to the class of tree, the soil and the depth to sheet water. Ordinarily, forest trees are divided according to their root systems into three classes. These are: Those having tap roots; those having no tap roots but only lateral fibrous roots; and those having both a small tap root and many fibrous roots. When trees that normally develop heavy tap roots are grown on soils where the ground water level is very near the surface, the tap root will be materially shortened or entirely wanting. Fibrous rooted trees growing in loose soils not troubled by bad drainage, may send heavy lateral roots to considerable depths. The highly resinous tap roots of such trees as the pine decay very slowly."

Several factors very materialy influence the blasting of stumps, notable of which are:

The character of the root, whether tap or fibrous.

The nature of the soil with regard to the resistance it offers the explosive.

The state of preservation of the stump, whether sound or partially decayed.

Freshly cut or green stumps are much harder to blast than those from which the small fibrous roots and bark have decayed.

Tap rooted stumps are easier to blast than fibrous rooted ones. The semi-tap rooted ones are slightly more difficult to blast than the tap rooted ones, but not so difficult as the fibrous rooted ones.

In doing successful and economical stump blasting all depends on the proper location of the charge. For stumps of the tap-root variety the best method is to bore into the tap root as shown in Fig. 119. The usual method of doing this is to start a hole with a $11 / 2$-inch punch bar or dirt auger at a distance away from the center of the stump equal to its diameter, inclined at an angle of about 45 degrees towards the center until the tap root is encountered. The earth tool should then be exchanged for a wood auger and the hole continued to $3 / 4$ of the way through tap root. Care should be exercised not to bore entirely through this as in that case a good deal of the force of the dynamite when it explodes will be wasted in the soft ground beyond the tap root. The charge to be employed should vary from 1 to 6 cartridges of Red Cross Extra $40 \%$ Dynamite, the size of the charge varying in proportion to the size of the stump. Charge should be primed with cap and fuse and firmly packed-the tighter the better. Priming, charging and tamping instructions are found on pages 119 to 124 .

If you have a blasting machine and Victor Electric Fuzes and you wish to avoid the necessity of boring into tap root, we recommend placing the charges of dynamite firmly against the tap root as in Fig. 120. Charges should be primed witl No. 6 Victor Electric Fuzes and firmly tamped. The electrical blasting methods are fully explained on pages 125 and 126. 


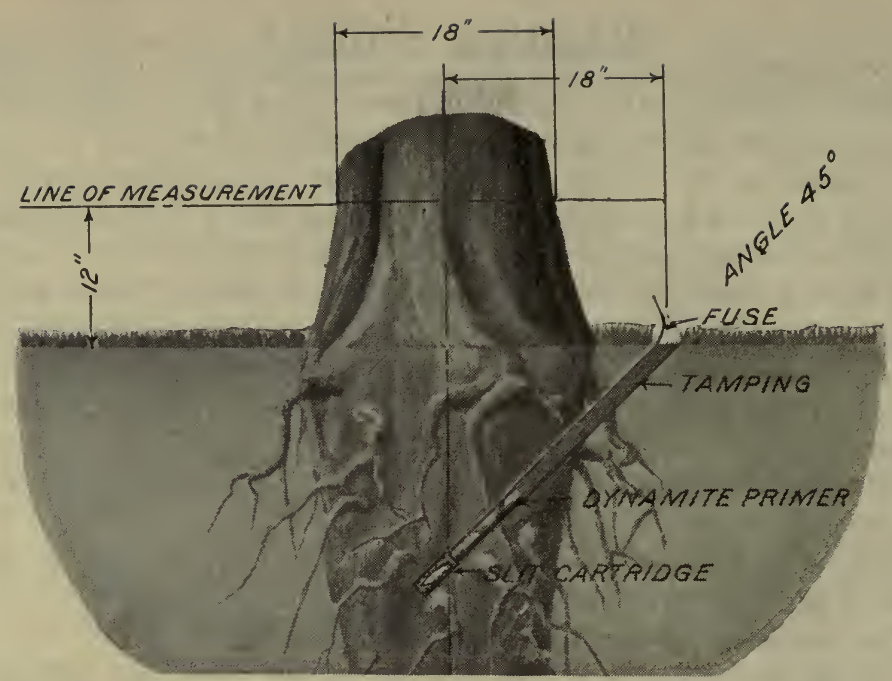

SHOWING CORRECT LOCATION OF CHARGE PLACED INTO TAP ROOT

FIG. 119

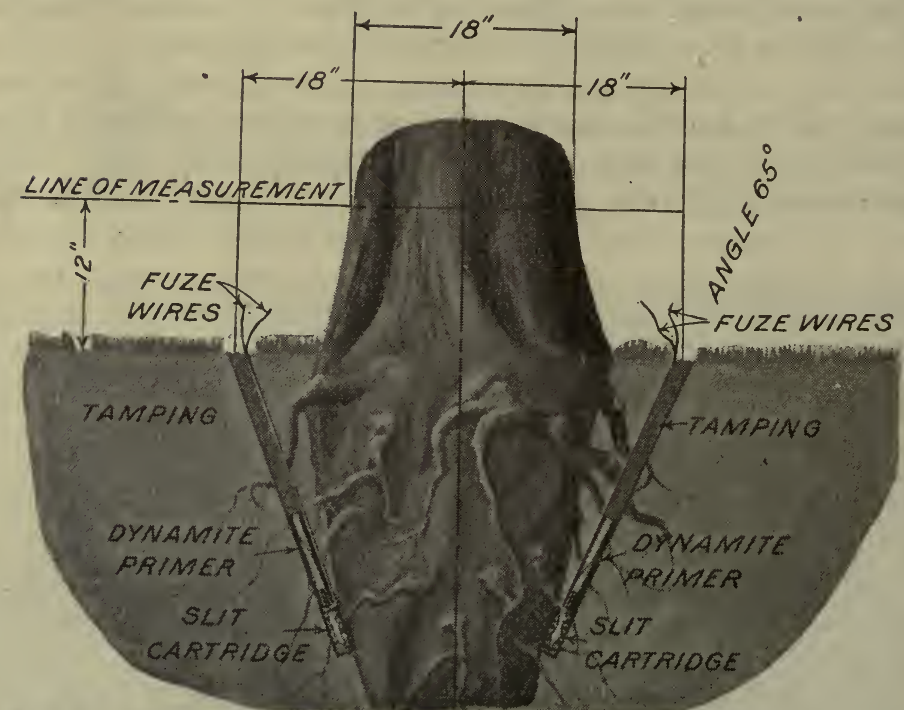

METHOD OF PLACING CHARGES AGAINST TAP ROOT FOR ELECTRICAL BLAST

FIG. 120 
When blasting out stumps of the semi-tap or lateral root variety, that is stumps having both tap and lateral roots, the paramount idea is to remove not only the part of it that projects above the ground, but to cut off and displace the roots below plow level. It is therefore necessary to place the charge well down in a central position below the stump in order that the explosion may exercise an equal pressure on all the roots.

A good many beginners in trying to carry out this principle make the common mistake of calculating to get the bottom of the borehole under the center of the stump as we endeavor to show in Fig. 121. As may be observed that point would be the ideal location for the charge, but it must be taken into consideration that if a charge of 3 cartridges is used in a $1 \frac{1}{2}$-inch borehole, this will occupy at least 20 inches of the length of same, thereby leaving very little space for thorough tamping.

Furthermore, the bulk of the charge would not be under the center of the stump and would have the tendency to blow out the loaded side only and in doing so it would probably remove only half of the stump, leaving the other half remaining in the ground, with practically no soil resistance to enable the blaster to put a fresh charge on the opposite side.

It is therefore apparent that an effort should be made to locate the centre of the charge at a point beyond the centre line of the stump, as shown in Fig. 122. To accomplish this correctly, a $11 / 2$-inch diameter hole should be bored at an angle of about 45 degrees inclined towards the center of the stump. This hole should be started at a distance away from the center of the stump equal to its diameter, and should be of sufficient length so that the bottom of same will be past the center line of the stump. Primer should be made with cap and fuse. The instruction for making the primer as also regarding loading and tamping should be carefully carried out as contained on pages 119 to 124 .

Stumps having a large diameter can also be blasted out by the cap and fuse method with a single charge by boring a hole past the center line and enlarging end of same with one-quarter of a cartridge of dynamite primed with cap and fuse. This small charge should be pressed down to the bottom of borehole and should not be tamped. The result will be as shown in Fig. 123. Under no consideration should the hoie be charged until it has had time to cool off. The best plan is to work on other stumps awhile to give the chamber ample time to cool.

We recommend, however, that large stumps be blasted electrically. This is done by boring auger holes either partly through or under the principal spreading roots and one deep hole placed under the center of stump (Fig. 124). All charges should be primed with No. 6 Victor Electric Fuzes, wires of which should be connected together to form a circuit. The first and last wires remaining should be attached to the two leading wires which are connected to blasting machine. Although large stumps can be successfully blasted by the ordinary cap and fuse method, we recommend the electrical system, as there is an econony in dynamite and results more satisfactory. 


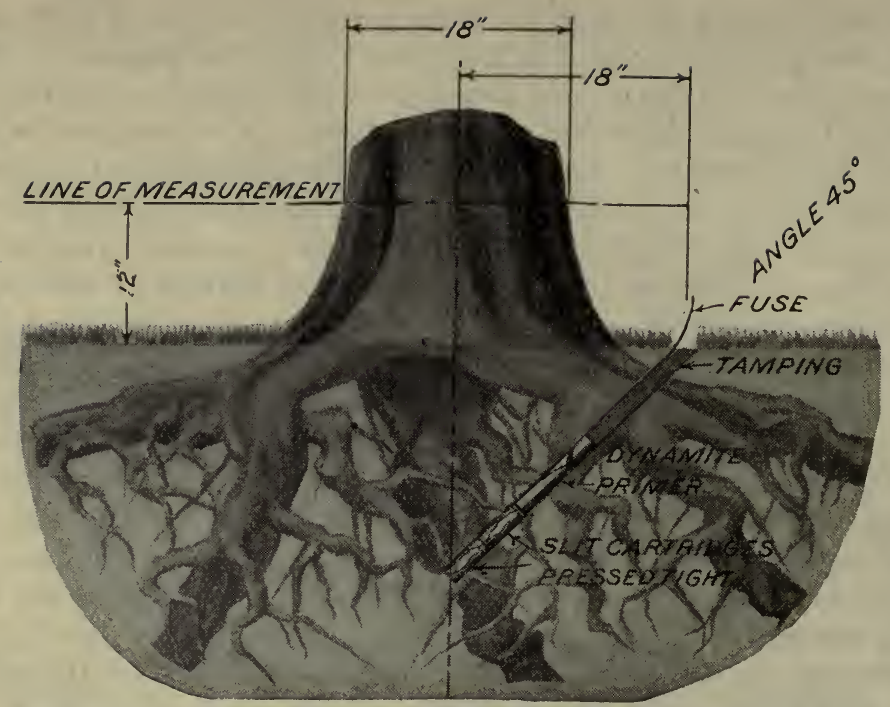

SHOWING INCORRECT LOCATION OF CHARGE BORE HOLE NOT LONG ENOUGH

FIG. I2I

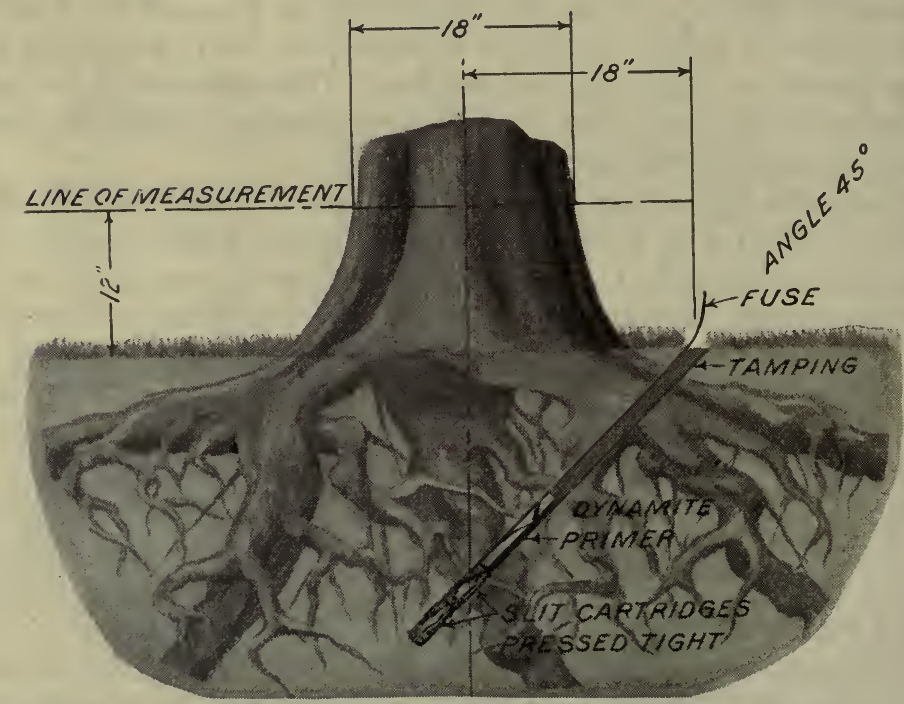

SHOWING CORRECT LOCATION AND DEPTH OF CHARGE

FIG. 122 
For cypress, willows or stumps in very soft soil the following method of blasting is recommended. Place three to six holes (according to size of stump) twelve to eighteen inches away from stump between lateral roots at an angle of about 75 degrees inclined towards center of same (Fig. 126A). Each hole should be charged with one or more cartridges of Red Cross Extra $40 \%$ primed with electric fuze and fired with blasting machine. By adopting this method, the stump will be split into six or seven pieces and all roots extracted, leaving a very slight indentation in ground.

\section{Table of Stump Charges}

The following table will enable the beginner to obtain an idea of the number of Red Cross Extra 40\% Dynamite cartridges required for various size stumps. These figures are for old but sound stumps. Fresh, green stumps will require one-half more or twice as much dynamite, and partly decayed stumps less than amounts shown. After he has obtained a little efficiency in doing his work he will see that he can in the majority of cases considerably reduce these charges.

\begin{tabular}{|c|c|c|c|c|c|c|c|c|c|c|c|}
\hline Diameter of Stumps in Inches & 12 & 18 & 24 & 30 & 36 & 42 & 48 & 54 & 60 & 66 & 72 \\
\hline $\begin{array}{l}\text { Approximate No. of } 1 t^{\prime \prime} \times 8^{\prime \prime} \\
\text { Cartridges Red Cross } \\
40 \% \text { Extra Dynamite. }\end{array}$ & I $1 / 2$ & 2 & 3 & 4 & 6 & 8 & I0 & I 2 & I4 & I 8 & 22 \\
\hline
\end{tabular}

\section{0\% Red Cross Dynamite for Stumping}

In many soils, except loose sand or swamps, it is possible to blast out stumps more economically with $20 \%$ Red Cross Dynamite than with the $40 \%$ strength. On the other hand in very loose or swampy soil it is sometimes advantageous to use Du Pont N. G. Dynamite, 60\% strength. The theory is this: Sand or muck will blow out much easier than the stump and offers little resistance. Hence, unless there is a good amount of sand or muck between the charge and the stump, the stump may not be blown out. But $60 \%$ N. G. Dynamite is so fast and powerful it blows the stump out before its power is lost through the sand or muck. On the other hand where the soil is loam or clay it offers good resistance and confines the force of $40 \%$ or $20 \%$ Red Cross Dynamite long enough to ensure getting out the stump. 


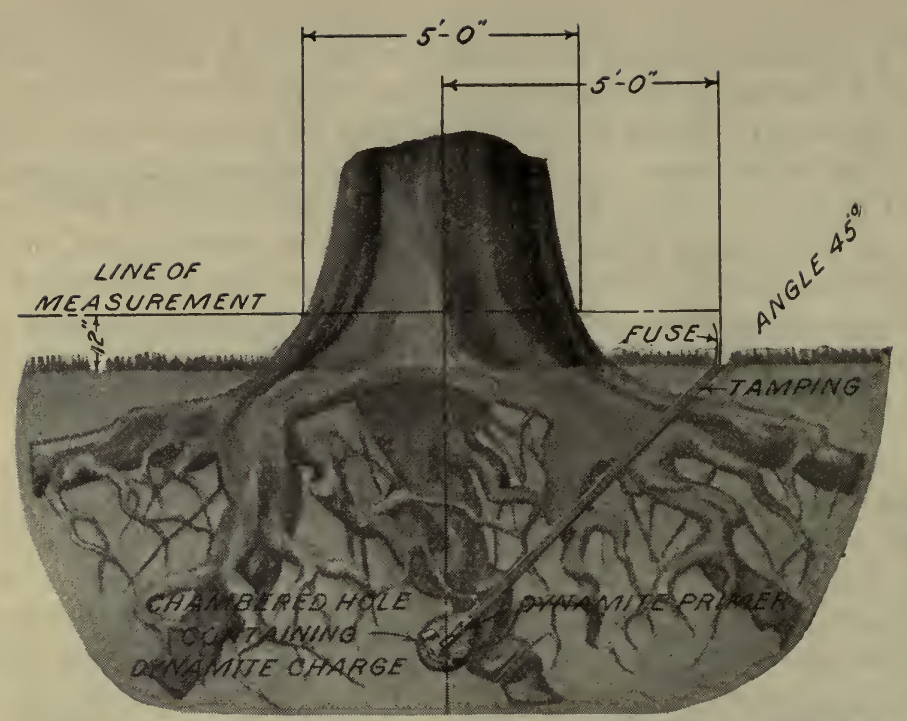

SHOWING "CHAMBERED" OR "SPRUNG" BORE HOLE FOR BLASTING LARGE STUMPS WITH ONLY ONE CHARGE

FIG. 123

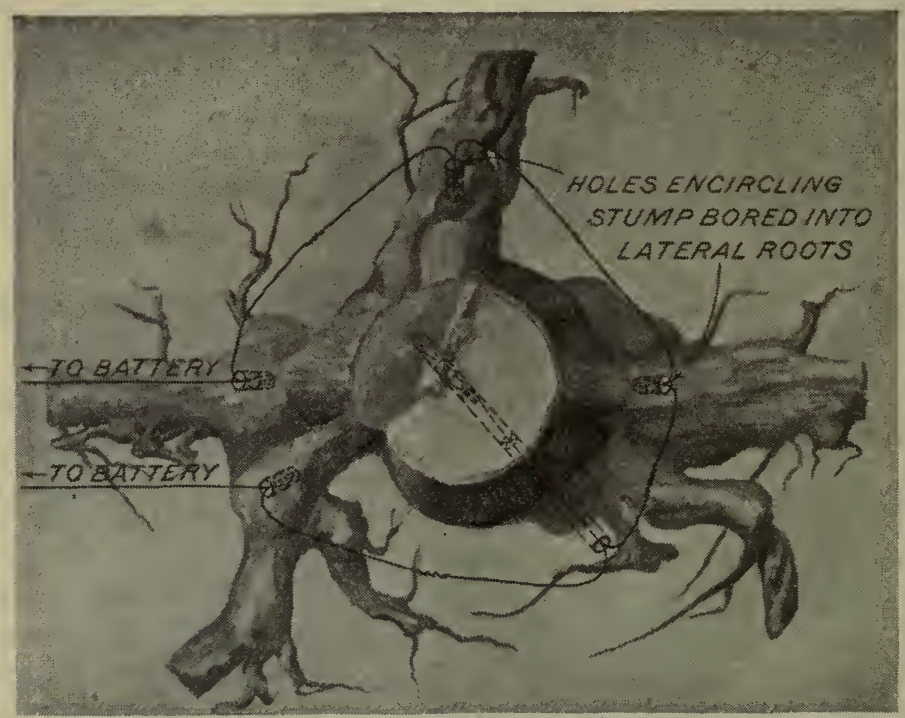

ELECTRICAL BLASTING-TOP VIEW SHOWING CORRECT LOCATION OF HOLES BORED INTO LATERAL ROOTS AND METHOD OF CONNECTING FUZE WIRES

FIG. 124 


\section{Western Fir, Pine and Cedar Stumps}

In the States of Washington, Oregon and parts of California, where the rainfall is large and the ground in the forests is always damp, many of the trees grow to great size-some being eight or ten feet in diameter. The roots of these trees usually spread out near the surface and do not grow deep into the ground as might be expected, tap roots being extremely rare.

The object when blasting these stumps is not to split them but to bring them out entire at one blast, with all of the roots possible, because if the charge of explosives is so gauged and located as to split the stump, it generally fails to bring out all of the pieces. As the principal object is to get out as much of the stump as possible at a minimum cost, it is better to blast it out first and then it can be easily split afterwards by means of a small quantity of dynamite exploded in auger holes.

The common rule in blasting these stumps is to use one and one-half pounds of Hercules Powder-Stumping L. F. per foot of diameter, with stumps up to four feet, when the subsoil is clay. For larger sizes from two to two and one-half pounds for each foot in diameter should be used. Stumps in gravelly or loose ground require one pound more for each foot in diameter.

The charge of explosives is best placed when there is sixteen to twenty-four inches of earth between it and the bottom of the stump. This results in the force of the explosion radiating to all sides, lifting the stump clear of the ground, and bringing with it the greatest length of roots. If the charge is placed too close to the stump, the effect is to split it, leaving the roots to be dug out at extra labor and expense.

When these stumps are large the bottom of the borehole is "sprung" or chambered until it is so large that the increased charge required can be concentrated under the center of the stump. The chambering is done by exploding without tamping, first a half cartridge, then several successive charges of from one to five cartridges each in the bottom of the borehole. When the hole is large enough it is given time to cool off and is then charged with the necessary quantity of Hercules Powder-Stumping L. F. to bring out the stump. Under no consideration should the hole be charged until it has had time to cool off.

The best plan is to work on other stumps awhile to give the chamber time to cool.

See pages 119 to 126 for proper methods of priming, charging, tamping and firing. 


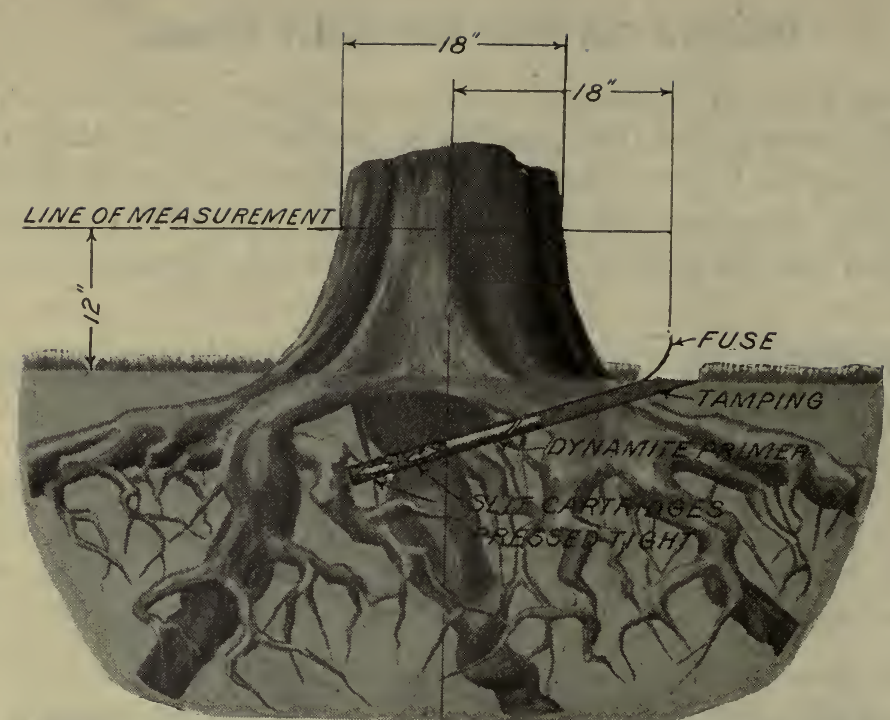

BORE HOLE TOO SHALLOW AND CHARGE PLACED TOO CLOSE TO BOTTOM OF STUMP

FIG. 125

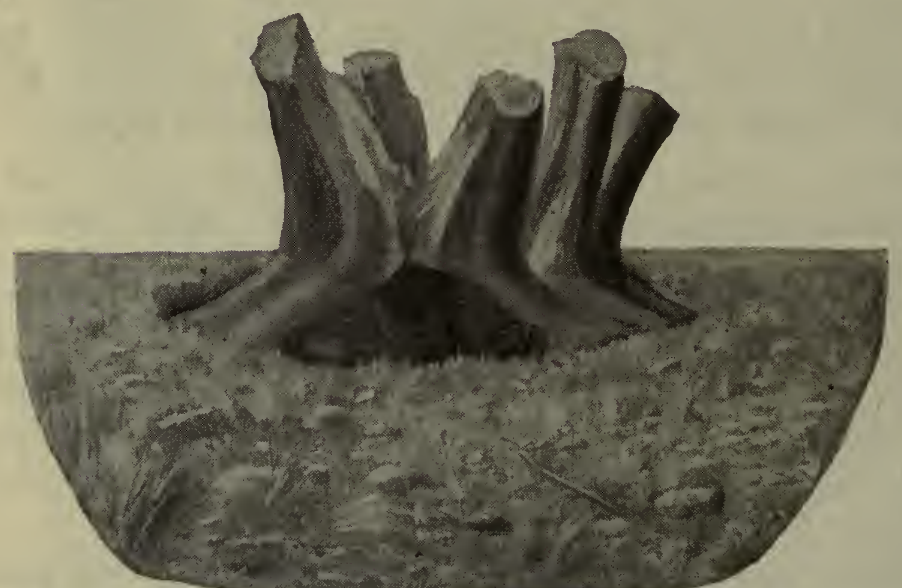

RESULT ATTAINED WHEN CHARGE IS PLACED TOO CLOSE TO BOTTOM OF STUMP AS SHOWN ABOVE

FIG. 126 


\section{Redwood and Bigtree Stumps}

The way to estimate the quantity of Hercules Powder-Stumping L. F. necessary to blast out stumps larger than eight feet in diameter, is to square the largest diameter in feet, the result being approximately the number of pounds required. For example, if a stump is eight feet in diameter the charge of Hercules Powder-Stumping L. F. should be about the square of eight, or sixty-four pounds. Stumps less than eight feet in diameter require a little greater charge for their size than do the larger stumps, and the rule with them is to use as many pounds of Hercules Powder-Stumping L. F. as eight times the largest diameter in feet. On this basis a stump six feet in diameter would need about fortyeight pounds of powder. However, the successful blasting of these large stumps depends greatly on the judgment of the blaster, and these rules can only be considered as a general guide. This can easily be understood when it is remembered that, owing to difference in soil or some peculiarity in the growth of the tree, it sometimes requires the same quantity of explosives to properly bring out a stump six feet in diameter as it does another one eight feet in diameter.

In blasting these stumps a trench is dug large enough to permit placing the entire charge of explosives directly underneath the center of the stump. A little powder blasted in holes punched with a crowbar will prove of great assistance in digging this trench. (See Fig. 127.)
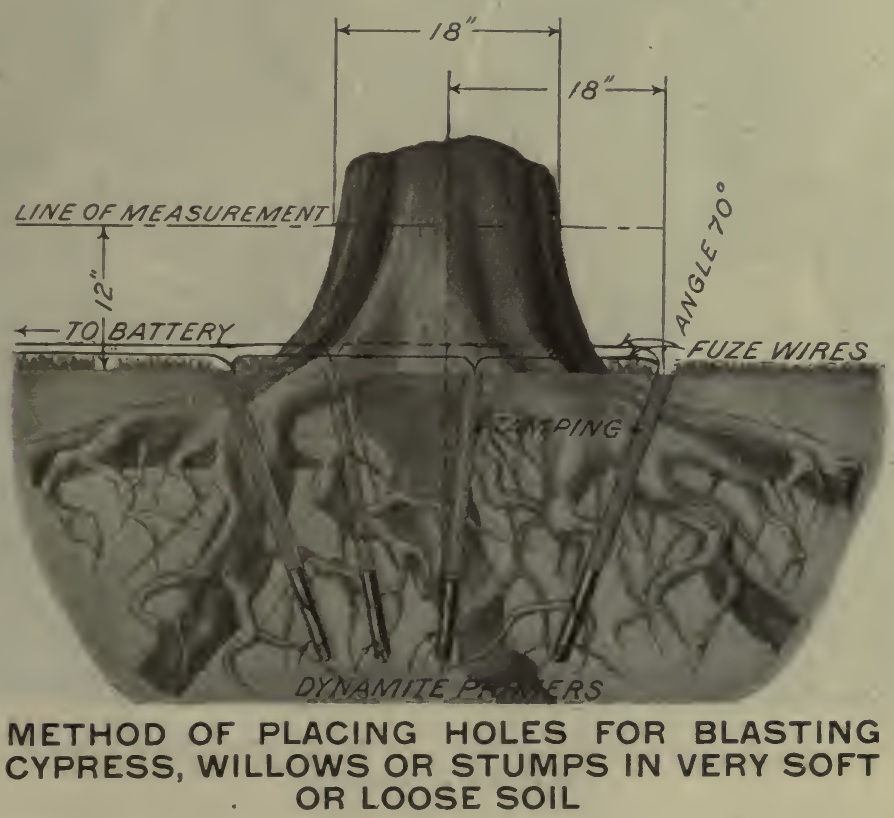

FIG. $126 \mathrm{~A}$ 


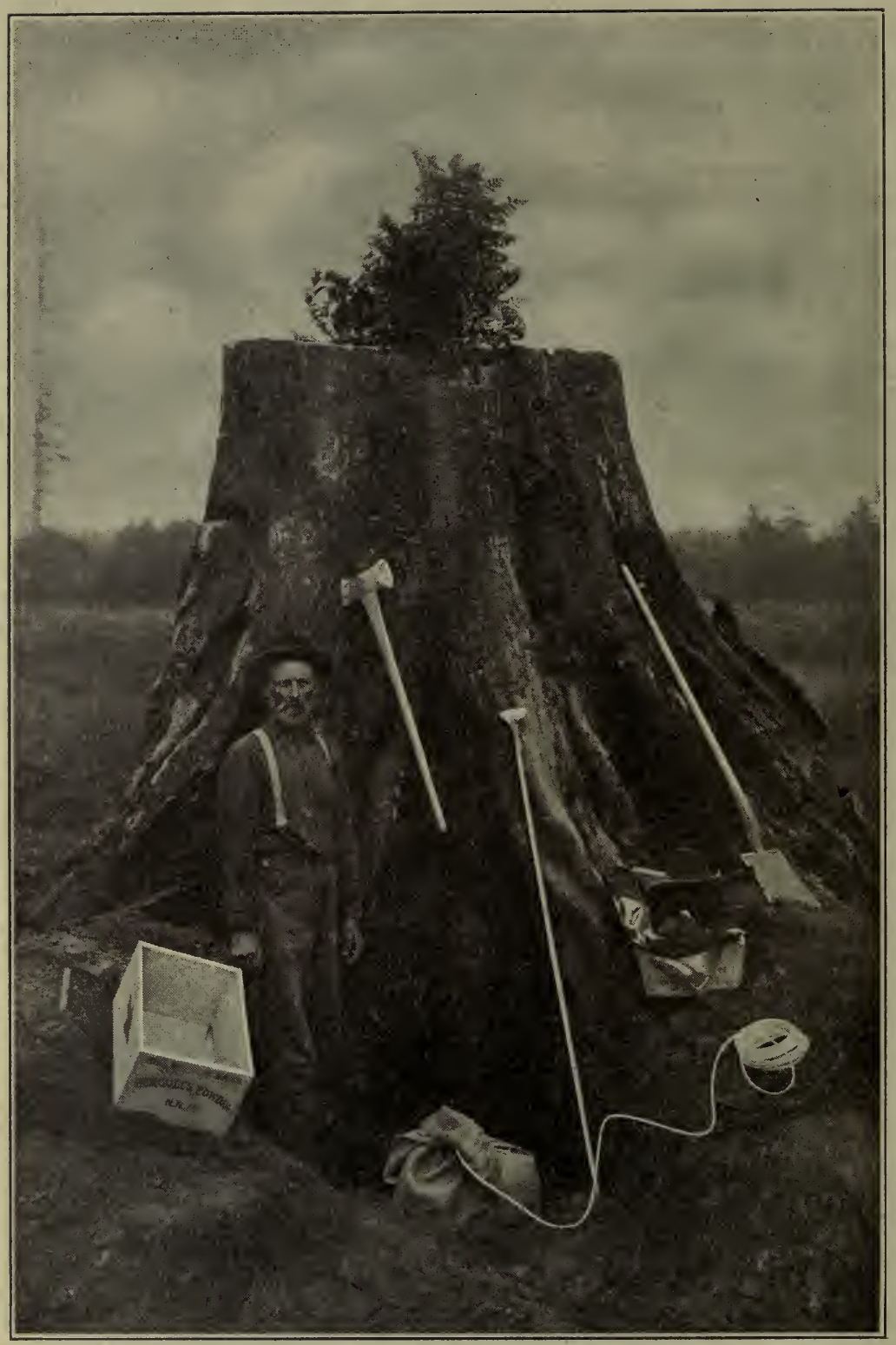

FIG. I27.-ILLUSTRATING METHOD OF PLACING CHARGE UNDER A CALIFORNIA BIG-TREE 
The charge should be firmly tamped. Avoid being on the same side of the stump as the trench when the blast is fired, as fragments, etc., are thrown with more violence and to greater distances on that side.

\section{Second-growth Stumps}

There is often directly under a second-growth stump the decayed remains of the original stump; this is soft, and the force of the explosive when placed on it seems to merely scatter this dead wood and has no marked effect upon the stump above. To overcome this difficulty, it is a good plan to dig under the stump and place a good sized flat stone between the roots, leaving only room on top of stone for the dynamite. Damp clay should then be firmly packed around the dynamite. This gives sufficient resistance to the explosive to enable it to lift out the stump. Red Cross Extra 40\% dynamite should be used. See pages 119 to 126 for proper method of priming, charging, tamping and firing.

\section{Felling Trees}

Occasionally when clearing land of growing timber, it is of advantage to blast out the entire tree and saw off the root afterwards.

This process here is exactly the same as in stump blasting, but a little more dynamite is required to bring out the tree, roots and all, than to blast the stump after the tree has been cut and the lower part of the trunk is usually split some. The blast lifts the tree straight up a foot or two; then it falls, generally with the wind. See pages 119 to 126 for proper method of priming, charging, tamping and firing.

\section{Splitting Stumps and Logs}

When stumps, particularly large ones, are blasted out whole or nearly so, it is sometimes necessary to split them up so that they can be conveniently handled or burned. This can be readily accomplished with dynamite; only a small quantity of explosives being required if the charge is properly tamped in auger holes bored part way through the stump.

In the South the pine stumps are very large producers of turpentine and by-products. Nothing is so effective as dynamite for breaking up a stump for this purpose. Charges of a few inches of Red Cross $40 \%$ Extra Dynamite, exploded simultaneously in several auger holes bored in the stump, will shatter it up into exactly the size required.

When logs are split up to be burned quickly, the same method is used as when splitting stumps; but if they are to be split for fence rails, cordwood, charcoal, or other purposes where comparatively even and regular sections are required, Du Pont Blasting Powder, in granulation FF, FFF or FFFF, should be used. 

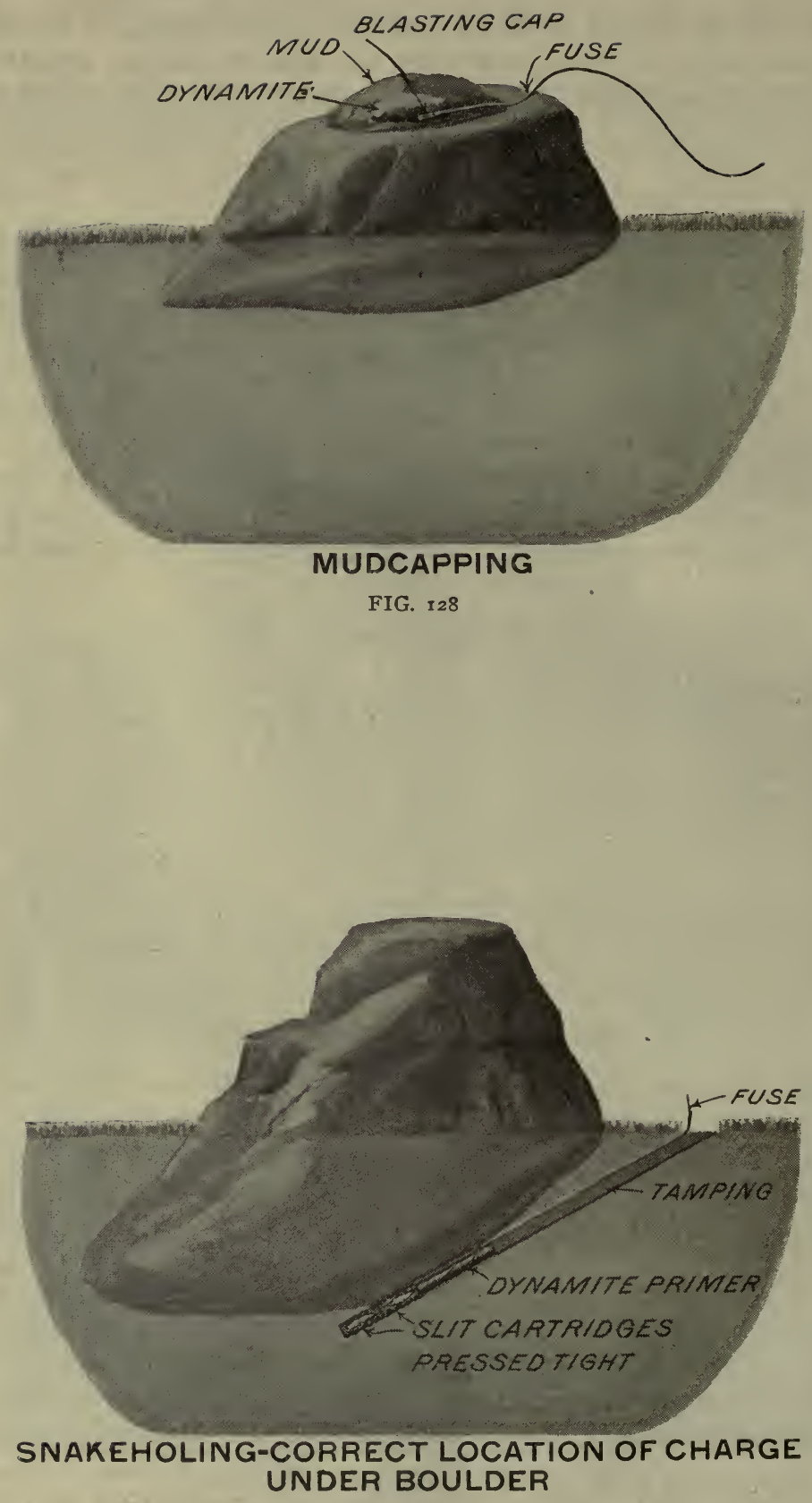

FIG. 129 
This explosive is so much slower in action than dynamite that a series of properly gauged and properly placed charges will split a log along the grain, just as evenly as if a number of wedges were used.

This method of splitting logs is so much quicker, cheaper and easier than any other, that those who have once become proficient at it never give it up. Auger holes one inch or more in diameter are bored along the line of the grain, about one-quarter to one-half of the way through the $\log$, the depth of the holes and the distance between them depending on the kind of wood, the grain and the diameter of the log. A few ounces of FF Blasting Powder are put into the bottom of each hole, care being first taken to see that the hole is dry, then wooden plugs are driven firmly into the tops of the holes to tamp or confine the charge.

In some kinds of wood it is best to leãve a considerable air space between the bottom of the plug and the powder. The plug must have a groove in the side large enough to admit the electric squib wire or the fuse. As blasting powder is exploded by a spark or flame it is not necessary to use a detonator with it. Electric squibs are similar in appearance to electric fuzes, except that they have a paper capsule instead of a copper cap. They do not explode when the electric current passes through them, but ignite the blasting powder by a flash. If electric squibs and a blasting machine are used for exploding the charges, they can all be fired simultaneously. This usually is the best and cheapest way as a little less powder is required than when the charges are exploded separately with fuse. When using electric squibs, it is only necessary to have the groove or channel in the sides of the wooden plugs large enough for the two small wires to run through it, if the cap of the electric squib is put in place before the plug is driven in. When driving the plug care must be taken that the wires are kept free, and that the insulation on them is not damaged. If it is not convenient to provide wooden plugs in this work, damp clay tamping may be used on top of a wad of newspaper. A log two feet in diameter and four or five feet long, can usually be split in two with one two-ounce charge of $\mathrm{FF}$ Blasting Powder. Longer logs require two or more holes and logs of greater diameter require heavier charges. The holes should be from one to two inches in diameter.

Logs may all be split into fairly regular sections with dynamite if care is taken not to use too much. To split a solid oak log ten feet long and four feet in diameter, two or two and a half $11 / 4 \times 8$-inch cartridges of Red Cross Extra 20\% Dynamite are exploded in a hole drilled from the outside to the center of the log, midway between the ends. This will sometimes split the log in quarters if the charge is properly confined with tamping. Only about half as much dynamite is required to split a poplar $\log$ of this size. A two-foot pine log twenty feet long can usually be split in halves with a single $11 / 4$ x 8 -inch cartridge or less of Red Cross Extra $20 \%$ Dynamite exploded as described above. 


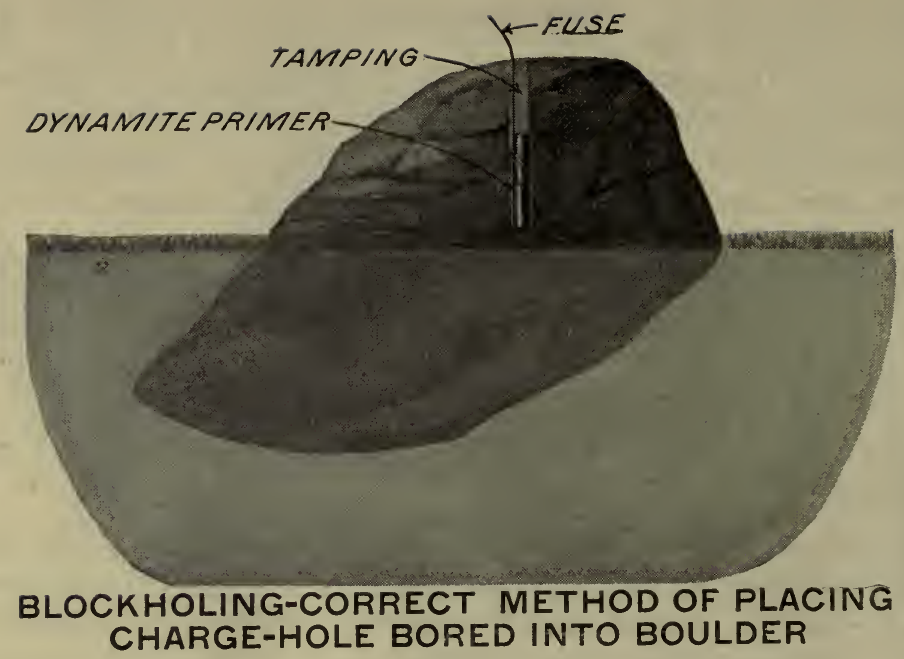

FIG. 130

\section{Table of Fuse Lengths}

This table is. based on an average burning speed of Crescent Fuse of 3 feet per minute. However, fuse that has been loosely rolled-thus admitting more air to the powder train inside the fuse, will burn more rapidly. Also, fuse in tightly tamped holes, being under pressure, burns more rapidly. In extreme cases the speed reaches 5 feet per minute. In subsoiling, as there is very little material thrown up, the fuse may safely be cut just long enough to reach from the charge of dynamite to a few inches above the surface of the ground. But in stump blasting, ditching and especially in boulder blasting it is necessary to use a fuse long enough to allow the blaster plenty of time to run far enough away to be out of reach of flying stones or sections of stumps. When a safe distance has been reached keep the eyes on the stump or boulder until the blast occurs, then look upward for falling pieces.

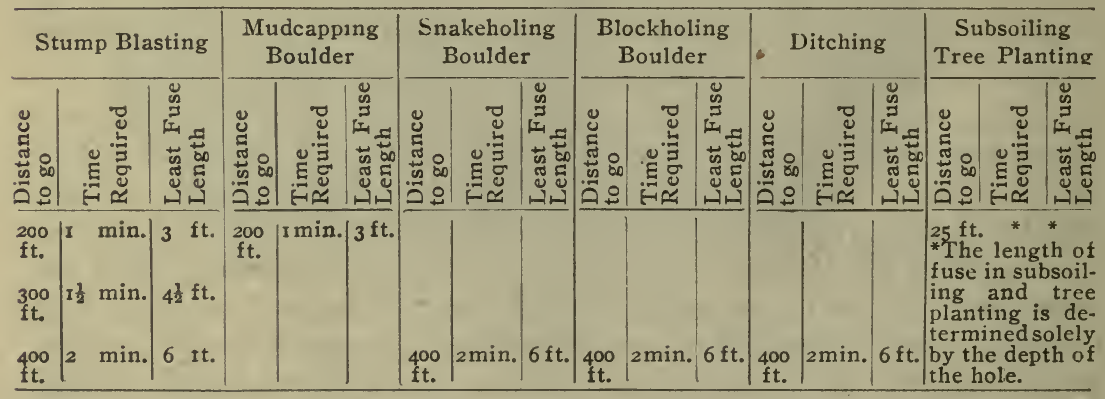




\section{Boulder Blasting}

There are three ways in which boulders can be blasted. These are known as "Mudcapping," "Snakeholing," and "Blockholing." "Mudcapping" and "Snakeholing" are the easier and quicker methods, but require more dynamite. It is almost impossible to shatter large round boulders of hard rock by either of these methods, without using an excessive quantity of explosives.

\section{Mudcapping}

When blasting boulders by mudcapping them (also called "doby shooting" or "blistering") the charge of dynamite is packed closely against the surface on the top or side of the boulder, covered with mud and exploded. The charge should be placed on the spot which would be struck with a sledge if the boulder were small enough to be broken in that way, and should be packed in a solid mass by removing the paper cartridge shells, but not spreading the contents over the surface of the boulder any more than absolutely necessary. When working with bare hands, it is a good plan to cover the dynamite with the original paper wrappers of the cartridges to prevent absorption of nitroglycerin by the pores. This paper also protects the dynamite against the water in the mudcap. A blasting cap crimped on to fuse should be placed in the middle of the charge, and the whole covered with six inches of damp clay or sand. The idea is to get the mass of explosive in direct contact with the boulder and exclude all air cushions. The mud or damp sand should be pressed firmly over the mass of dynamite, care being taken not to cover the outer end of the fuse. If the boulder is deeply imbedded in the ground, it is best, before blasting, to dig away or loosen some of the earth surrounding it.

\section{Blockholing}

This is the most economical way to use dynamite in breaking up boulders, although it takes some time and labor to drill the one or more necessary holes in the boulder. The holes in large boulders should be an inch or more in diameter, while three-quarters or seven-eighths of an inch will answer for the smaller ones.

A boulder weighing from eight to ten tons can be well broken by drilling a one-inch hole in it near the center from two to three feet deep as the shape and grain of the rock may demand, and exploding in the hole four to five one and one-quarter by eight-inch cartridges of Red Cross Extra Dynamite $40 \%$. The dynamite should be poured out of the paper shells and packed down into the hole with a stick. When it is all in place a hole is made in it with a sharp stick and the blasting cap, crimped to the necessary length of fuse, is pushed down into this hole and held in position by carefully packing any clay tamping there is room for about the fuse. 
To break up a boulder weighing approximately a ton, a one-inch hole eight inches deep, charged from half to two-thirds full of Red Cross Extra Dynamite, is required. Smaller boulders require holes from four to six inches in depth, which, if necessary, can be filled full of Red Cross Extra Dynamite, and no tamping used.

\section{Snakeholing}

In this method of breaking boulders the dynamite is placed in holes underneath them just as in stump blasting. The hole is made with a crowbar or dirt auger in such a direction that the charge of dynamite will be against the center of the lower side of the boulder. If the boulder is hollow or flat underneath, the explosion of the charge will break it in pieces and throw it out of its bed. If the lower side is round or bulging the boulder will be heaved out, but will not be so well broken. When this occurs the large pieces may be broken by mudcapping. Care should be taken when the charge is placed to leave no means by which the force of the dynamite may be wasted. If it has not been thoroughly tamped, or if it is too near the surface of the ground and not in the proper position beneath the boulder, the dynamite may blow the dirt out and leave the boulder untouched.

Red Cross $40 \%$ Extra Dynamite should be used when breaking up boulders in this way. Only from one-half to two-thirds the quantity that would be required to mudcap the same boulder is needed, provided it has a hollow or flat side underneath. Less dynamite is required in damp, heavy soil than in light or sandy soil.

Caution: Blockholing and snakeholing boulders are the most dangerous operations in agricultural blasting, because pieces of rock are often thrown great distances. Hence it is necessary to get 300 to 400 feet away before the blast. To reduce the risk from flying stones, especially when blasting near a dwelling, cover the boulder with a number of leafy, branchy boughs. These tend to retard the flying stones the same as the rope blankets used by contractors in blasting in cities.

The quantity and strength of dynamite required naturally depends on the size and shape of the boulder. The "grain" and kind of rock are also important points. Red Cross Extra Dynamite $40 \%$ or Du Pont $60 \%$ N. G. Dynamite is best for blasting boulders. The following table gives approximately the number of $1 \frac{1}{4} \times$ x 8 -inch cartridges to blast boulders of different sizes, so that they will be broken into pieces small enough for one man to handle, provided the boulders are mostly above the surface of the ground. 
Table of Charges for Boulder Blasting

\begin{tabular}{|c|c|c|c|}
\hline \multirow[t]{2}{*}{ Weight of Boulder } & \multicolumn{3}{|c|}{$\begin{array}{c}\text { Approximate Number of } 1\}^{\prime \prime} \times 8^{\prime \prime} \text { Cartridges } \\
\text { Required for: }\end{array}$} \\
\hline & Mudcapping & Snakeholing & Blockholing \\
\hline $100 \mathrm{lbs}$. to $500 \mathrm{lbs}$ & $\frac{1}{2}$ to $I \frac{1}{2}$ & $\frac{1}{2}$ to I & $\frac{1}{2}$ \\
\hline 1000 lbs. & 2 & $1 \frac{1}{2}$ & $\frac{1}{2}$ \\
\hline $2000 \mathrm{lbs}$. & 3 & $2 \frac{1}{2}$ & 3 \\
\hline $3000 \mathrm{lbs}$. & 32 & 3 & I \\
\hline $4000 \mathrm{lbs}$. & 4 & $3^{\frac{1}{2}}$ & $1 \frac{1}{4}$ \\
\hline $5000 \mathrm{lbs}$. & $4^{\frac{1}{2}}$ & 4 & $1 \frac{3}{4}$ \\
\hline $7500 \mathrm{lbs}$. & 6 & 5 & $2 \frac{1}{2}$ \\
\hline I0000 lbs. & 8 & 6 & $3 \frac{1}{2}$ \\
\hline
\end{tabular}

If boulders are largely buried in the ground they may be broken by doubling or trebling the above charges, but it is generally less expensive under these conditions to lift the boulder out of the ground by snakeholing and then if it is too large to handle, to break it in pieces by mudcapping. For lifting without breaking, the charges in above table may be approximately reduced one-half.

\section{Ditching}

When properly used dynamite will excavate ditches entirely, spreading the earth over the land some distance away. In the same way much valuable land can be saved by blasting straight channels to straighten and shorten the course of creeks and streams. It is not necessary in this work to blast a large ditch or channel, for if the current is once started through a small one it will soon wash it out to the proper size.

Ditches can be dug economically and satisfactorily either through dry ground, or in wet heavy soil, even though it should be covered with several inches of water. The best and most systematic way of doing this class of work is to:

(1) Stake out and measure the entire length of the ditch required.

(2) Multiply the total length in feet by 12 inches and divide by 28 in order to ascertain the number of holes to be punched or bored. The divisor 28 is given to represent the normal distance between holes. In stiff clay or hardpan holes should be 26 to 28 inches apart. In loose or mucky soil where there will be a good flow of water to clean out bottom, holes may be 30 inches apart.

(3) Carry the necessary number of Red Cross Extra 20\% cartridges required (one or two per hole according to conditions), as also the number of Victor No. 6 Electric Fuzes with wires the required length according to the depth and spacing of the holes (one fuze to each hole), to where the work is to be done. 

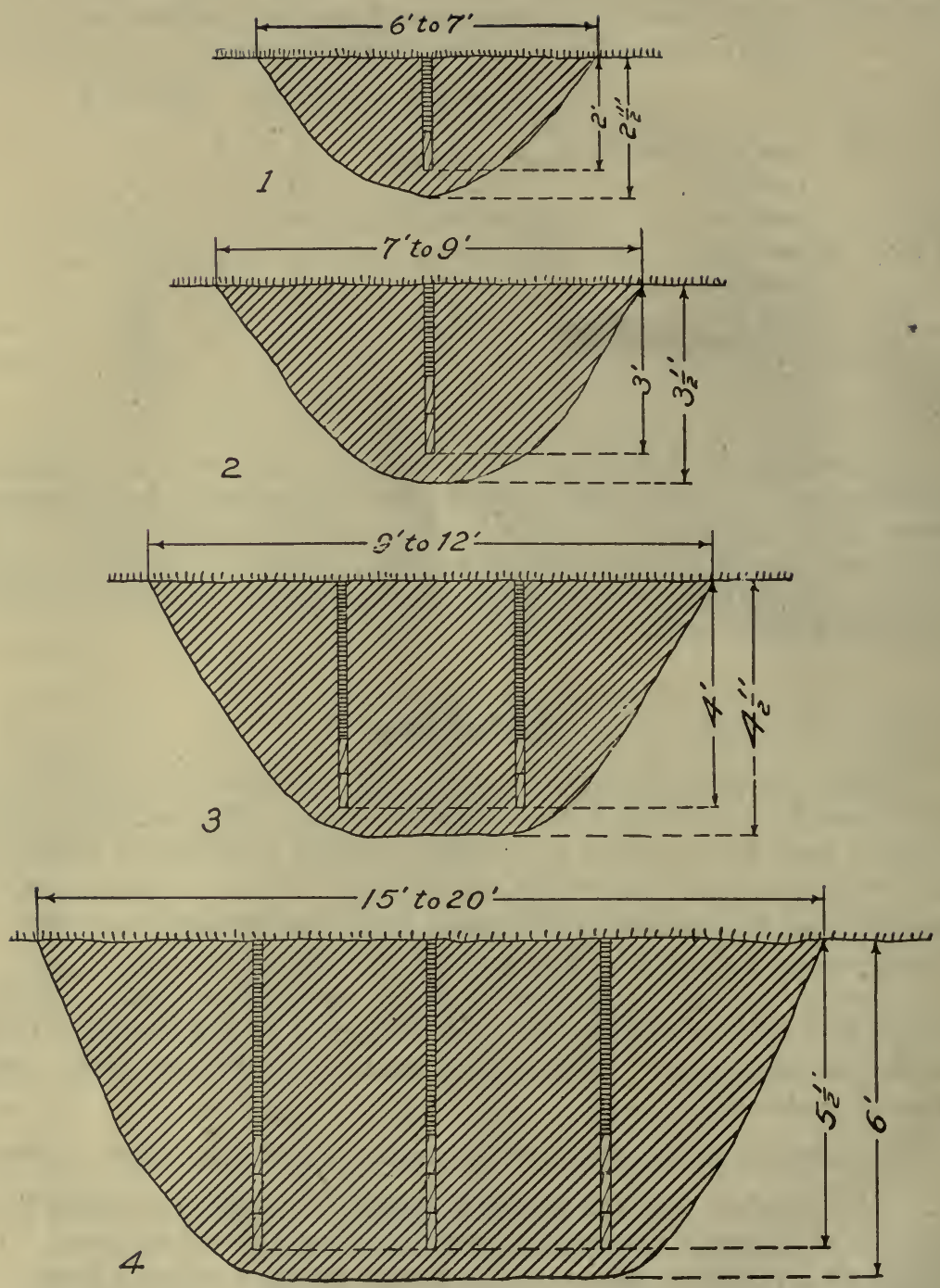

FIG. 13 I

Diagram showing approximate cross-section of blasted ditches with location and amount of charge required. No. 1 shows 1 cartridge tamped in, No. 2 two cartridges, No. 3 two cartridges in each of two holes, No. 4 three cartridges in each of three holes. 
(4) Prepare as many primers as there are holes required. Primers should be made in accordance with the instructions contained on page using for this purpose one Victor No. 6 Electric Fuze.

(5) Punch or bore a row of holes along the center line where the ditch has to be made. Holes should be made vertically with a bar not less than one and one-half inches in diameter, spaced 28 inches apart, and sunk to a depth approximately within 6 inches of the desired depth of the ditch. The number of holes bored for each blast should be consistent with the capacity of the blasting machine to be used.

(6) If the work is dry, charge the holes after they have all been bored to save time. If a charge of more than one cartridge is required, place the primed cartridge in last, and tamp well to top of the ground.

If the work is in very wet or swamp soil it is very often advisable to load the holes as soon as bored as wet shifting soil may refill the hole. No tamping is required if cartridges are well covered with water.

(7) Connect electric fuze wires in one of the ways illustrated on page 146.

(8) As soon as the last hole is charged stretch out leading wire and connect same to electric fuze wires, caution everyone to retire and when certain that every one is at a safe distance away connect leading wire to blasting machine and fire. Never connect leading wire to blasting machine until ready to fire.

In this way ditches can be dug up to 9 feet wide at the top, 3 feet wide at the bottom and $41 / 2$ feet deep for approximately $6 c$. per lineal foot or 8c. per cubic yard. The top width depends on the depth, size of the charge, kind of soil and consistency of same. When digging ditches requiring a width of from 9 to 20 feet, two or three rows of holes are necessary. The holes should be the same distance apart in the rows, the same depth and charged with the same quantity and kind of dynamite as for the narrower ditches.

Note: If in doubt as to the proper depth of holes or charge, try a short test blast of five to ten holes.

If the first hole in the second or succeeding sections is spaced the regular 26 or 28 inches away from the end of the first blast, a ridge will be left at that point in the finished ditch. To overcome this, place the first charge in each string not more than a few inches, away from the end of the last blasted section.

In heavy dry soil it may prove advantageous to load at the bottom of each hole one cartridge of Red Cross Extra $40 \%$ Dynamite, underneath the $20 \%$ load, the idea being that the weaker dynamite will break the upper soil and the $40 \%$ will then throw it out better than if $20 \%$ were used exclusively. It must be remembered that the kind and condition of the soil greatly affect the work, hence no hard and fast rules can apply.

In strongly sodded soil, cutting the sod with a spade along the proposed sides of the ditch help to produce a clean excavation. 

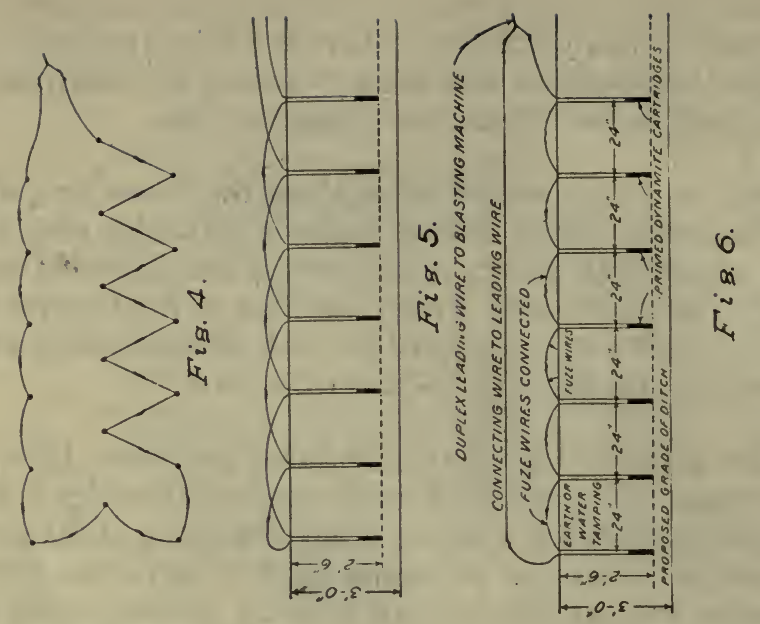


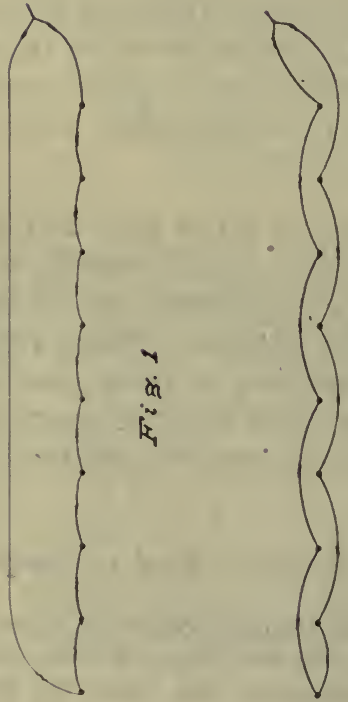

Q

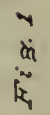

in

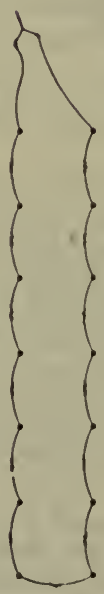

m

ai

Fig. 1 shows method of connecting single row of holes when the fuze wires are short, the leading wire being connected to the two ends of the series. Fig. 2 shows a method requiring less leading wire, both wires of the duplex leading wire being connected to separate fuze wires at one end of the series. Fig. 3 shows connections for a two-row blast, Fig. 4 for a thrée-row blast, Fig. 5 shows a vertical view of Fig. 2 connections, and Fig. 6 a vertical view of Fig. 1 connections. 


\section{Table of Charges for Ditch Blasting}

\begin{tabular}{|c|c|c|c|c|c|c|}
\hline \multirow{2}{*}{$\begin{array}{l}\text { Approximate tup } \\
\text { width of ditch } \\
\text { in feet. }\end{array}$} & \multicolumn{3}{|c|}{$\begin{array}{l}\text { Approximate No. of ctgs. re } \\
\text { quired for various depths. }\end{array}$} & \multirow{2}{*}{$\begin{array}{l}\text { No. of rows of } \\
\text { holes required. }\end{array}$} & \multirow{2}{*}{\multicolumn{2}{|c|}{ Distance between rows. }} \\
\hline & 2l to $3 \mathrm{ft}$. & 4 & 5 to $6 \mathrm{ft}$. & & & \\
\hline 3 & $\frac{1}{2}$ & & & I & & nches \\
\hline 6 & I & 2 & 3 & I & 0 & “ \\
\hline 8 & I & 2 & 3 & 2 & 20 & “ \\
\hline IO & I & 2 & 3 & 2 & 28 & is \\
\hline 12 & I & 2 & 3 & 2 & 36 & “ \\
\hline 14 & I & 2 & 3 & 2 & 42 & $" 1$ \\
\hline 16 & I & 2 & 3 & 3 & 42 & $"$ \\
\hline
\end{tabular}

Required length of

No. 6 Victor Electric Fuzes.

$4 \mathrm{ft} . \quad 6 \mathrm{ft} .6$ to $8 \mathrm{ft}$.

\section{Blasting Ditches Without a Blasting Machine}

There are occasions when a ditch has to be cut through very swampy and untrafficable muck, which makes it very difficult for the blaster to conveniently carry out all the work necessary when the blasting machine has to be used. Then again in the same soil it may be imperative to cut a ditch 300 to 500 feet in length in one blast, which cannot be done by means of a blasting machine, as a blasting machine will fire from 30 to 250 feet at one time according to its size. When this occurs the following method should be adopted:

Punch or bore a row of holes vertically along the center line of the proposed ditch with a bar not less than $1 \mathrm{~T} / 2$ inches in diameter, down to a depth approximately within 6 inches of the desired depth of the ditch, spacing them from 18 to 24 inches apart. Each hole should be charged, as soon as made, with one or more cartridges of Du Pont N. G. $60 \%$ Dynamite according to depth, as soon as bored. Place in the center hole one extra cartridge primed with a blasting cap carefully crimped to the proper length of waterproof fuse. No tamping is needed provided mud or water covers the charge. The primed cartridge should not be loaded until everybody except the blaster has retired to a considerable distance from the line of the ditch in order to avoid the great amount of dirt thrown out around that vicinity. The primer fuse should be lighted just as soon as possible after the primer is loaded, the blaster, of course, retiring to a safe distance. The charge in the middle hole explodes those in the holes on either side, and the effect of these two is carried to the next and so on almost instantaneously to the ends of the ditch. 
Due to the fact that the closer spacing of holes and more expensive dynamite are required, this method is usually somewhat more expensive than when the electrical method is employed. It must be remembered that cold weather checks the action of Du Pont N. G. 60\% Dynamite and it is necessary to use larger charges and put the holes closer together than in warm weather. This work can be done best when the temperature of the water or earth is above 50 degrees Fahr., and is not recommended for lower temperatures.

For ditches with a width at the top greater than 6 feet two or three rows of holes are required. The holes should be the same distance apart in the rows, the same depth and charged with the same quantity and kind of dynamite as for narrower ditches. The following table shows the spacing of the rows and charge per hole required for various size ditches:

\section{Table of Charges for Blasting Ditch Without a Blasting Machine}

\begin{tabular}{|c|c|c|c|c|c|c|}
\hline \multirow{2}{*}{$\begin{array}{l}\text { Top width } \\
\text { of ditch }\end{array}$} & \multicolumn{4}{|c|}{$\begin{array}{c}\text { Approximate number of cartridges } \\
\text { per hole required for } \\
\text { various depths }\end{array}$} & \multirow{2}{*}{$\begin{array}{l}\text { Number of } \\
\text { rows required }\end{array}$} & \multirow{2}{*}{$\begin{array}{l}\text { Distance } \\
\text { between rows } \\
\text { in inches }\end{array}$} \\
\hline & $2 \frac{1}{2}$ to $3 \mathrm{ft}$. & $4 \mathrm{ft}$. & $5 \mathrm{ft}$. & $6 \mathrm{ft}$. & & \\
\hline 6 & I & 2 & $2 \frac{1}{2}$ & 3 & I & -. \\
\hline 8 & I & 2 & $2 \frac{1}{2}$ & 3 & 2 & 30 \\
\hline 10 & I & 2 & $2 \frac{1}{2}$ & 3 & 2 & 36 \\
\hline 12 & $\mathbf{I}$ & 2 & $2 \frac{1}{2}$ & 3 & 2 & 42 \\
\hline I4 & I & 2 & $2 \frac{1}{2}$ & 3 & 2 & 48 \\
\hline 16 & I & 2 & $2 \frac{1}{2}$ & 3 & 3 & 36 \\
\hline 18 & I & 2 & $2 \frac{1}{2}$ & 3 & 3 & 42 \\
\hline 20 & I & 2 & $2 \frac{1}{2}$ & 3 & 3 & 48 \\
\hline
\end{tabular}

In order to enable the blaster to calculate the amount of dynamite required to cut various size ditches, the following table used in conjunction with either of the preceding tables should prove very useful:

\begin{tabular}{|c|c|c|c|c|c|c|c|c|c|}
\hline \multirow{3}{*}{ Spacing } & \multicolumn{3}{|c|}{ Io Rods } & \multicolumn{3}{|c|}{ T/4 MiLe } & \multicolumn{3}{|c|}{ I/2 MiLe } \\
\hline & \multirow{2}{*}{$\begin{array}{c}\text { Number } \\
\text { of } \\
\text { holes }\end{array}$} & \multicolumn{2}{|c|}{$\begin{array}{c}\text { Dynamite required } \\
\text { using charges } \\
\text { per hole of }\end{array}$} & \multirow{2}{*}{$\begin{array}{c}\text { Number } \\
\text { of } \\
\text { holes }\end{array}$} & \multicolumn{2}{|c|}{$\begin{array}{c}\text { Dynamite required } \\
\text { using charges } \\
\text { per hole ot }\end{array}$} & \multirow{2}{*}{$\begin{array}{c}\text { Number } \\
\text { of } \\
\text { holes }\end{array}$} & \multicolumn{2}{|c|}{$\begin{array}{c}\text { Dynamite required } \\
\text { using charges } \\
\text { per hole of }\end{array}$} \\
\hline & & $\begin{array}{c}1 / 2 \\
\text { cartridg }\end{array}$ & $\begin{array}{c}\text { Whole } \\
\text { cartridge }\end{array}$ & & $\begin{array}{c}1 / 2 \\
\text { cartridge }\end{array}$ & $\begin{array}{c}\text { Whole } \\
\text { cartridge }\end{array}$ & & $\begin{array}{c}1 / 2 \\
\text { cartridge }\end{array}$ & $\begin{array}{c}\text { Whole } \\
\text { cartridge }\end{array}$ \\
\hline I8 ins. & IIO & $28 \mathrm{lbs}$ & $55 \mathrm{lbs}$. & 880 & 220 lbs. & $440 \mathrm{lbs}$ & 1760 & $440 \mathrm{lbs}$ & $88 \mathrm{olbs}$ \\
\hline $20 "$ & 99 & $25^{\prime \prime}$ & $49^{\prime \prime}$ & 792 & 198 “، & 396 “" & 1584 & 396 " & 792 “ \\
\hline 24 " & 83 & $21 "$ & $4 I \cdots$ & 664 & I66، & 332 “ & 1328 & 332 “ & 664 '، \\
\hline 26 ، & 76 & 19 " & 38 ' & 608 & I52 “ & 304 “" & I 216 & $304^{\prime \prime}$ & 608 “. \\
\hline 28 ، & 71 & $18 \cdots$ & 36 “ & 566 & 142 “" & 284 “، & II 32 & $28_{3}$ “" & 566 “ \\
\hline & & $1 / 2$ & $\begin{array}{l}\mathrm{d}= \\
\text { ds }= \\
\text { ile } \equiv \\
\text { ile } \equiv\end{array}$ & $\begin{array}{r}16 \frac{1}{2} \mathrm{f} \\
165 \mathrm{f} \\
1320 \mathrm{f} \\
2640 \mathrm{f}\end{array}$ & et or 8 & yards & 160 & & \\
\hline
\end{tabular}

If longer ditches or larger charges are required, multiply the above figures by two, three or four, according to the number of rows. 
Note: In case of doubt as to proper distance between holes or rows, or depth and strength of charges, try several 10-hole test blasts, with different charges at different distances and depths.

When wide ditches are blasted requiring two or three rows of holes, the center hole in each of the rows should be primed with a Victor No. 6 Electric Fuze. These should be connected together and fired by means of a blasting machine. In some cases, when the rows are not more than 36 inches apart, the blast can be effectually made by placing extra holes between the rows midway between the two center holes. The primed cartridge with cap and fuse is then inserted in the center hole of the middle row; the detonation then will carry by means of the extra holes to the other rows already charged as shown in the diagram below.

Note: Wasting of earth. The dirt excavated in a ditch blast will fall the way the wind blows. It is better to ditch on a windy day to obviate the possibility of dirt falling back into the ditch.

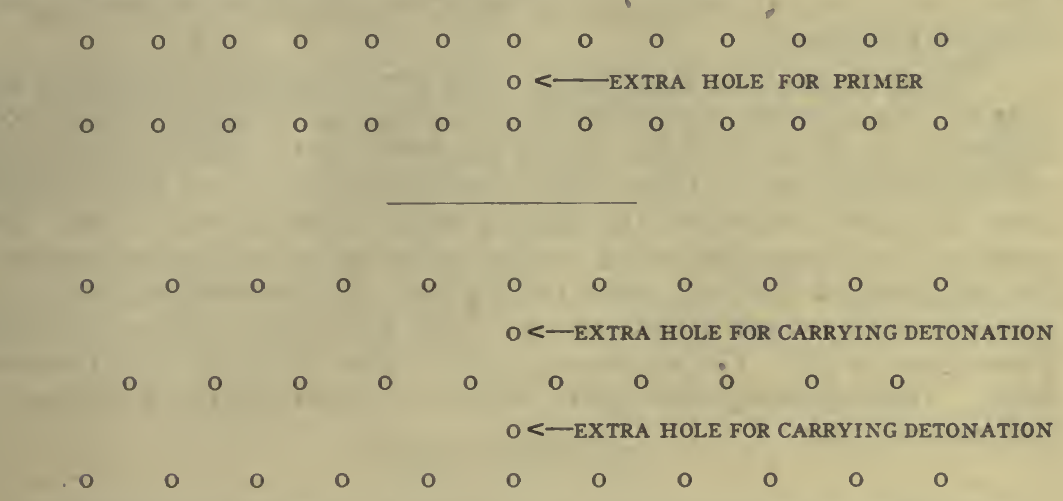

SHOWING LOCATION OF PRIMER HOLES IN PROPAGATED BLASTING OF DITCHES

\section{Draining Swamps and Ponds}

Swamps and ponds, except where they are close to rivers, lakes or the ocean, are caused by spring or surface water collecting on low ground without a lower outlet. As a rule they are underlaid by a hard clay or other impervious subsoils which prevent the water from sinking. In a great many instances it is impracticable to drain these by surface methods or ditching, yet they can often be permanently dried up by exploding deep charges of dynamite and shattering the impervious subsoil beneath. The number of charges required and depth of same depend of course on the size of area to be drained, the amount of water required to be sunk, and the thickness of the various subsoil strata encountered until the water-absorbing sand or gravel is reached. In order to determine the depth required, a test hole is hored with a dirt auger, which should be pulled up from time to time in order to clean hole out, as also to ascertain the nature of the soil encountered which is readily seen on the spiral thread of the auger. Once the water-absorbing sand or gravel is reached the depth of the hole is noted on the auger shank. This test hole must not be charged, as it is too deep. The hole or holes for charging should 
stop about 6 inches above the sand or gravel in shallow holes, and 12 to 18 inches in deep holes. It very often happens that holes have to be bored to depths averaging from 15 to 30 feet before the water-absorbing strata are reached and in order to do this it is necessary to use an extension auger. If the place where the holes are to be put down is covered with water too deep to work in, the boring should be done from a raft anchored in the proper position. It is much easier to operate the auger through a hole in the center of the raft than over the side. As soon as the hole has been bored to the required depth the auger is withdrawn and a piece of $1 / 2$-inch pipe sufficiently long to reach the bottom of same and 5 or 6 inches above the water level is inserted. Through this the dynamite cartridges are dropped one at a time and pushed to the bottom with a wooden tamping rod. A good firm push will hold each cartridge in position. The last cartridge but one is primed with a Victor Waterproof Electric Fuze and one cartridge is put on top of it to hold same in place, as it is not advisable to give the primed cartridge too hard a push with the tamping rod.

When the hole has been charged the loading pipe is withdrawn and slipped over the ends of the electric fuze wires, the leading wires are connected on to the electric fuze wires, the joints being carefully protected with insulating tape and the raft is poled to the shore or a safe distance away from the hole while the leading wire is carefully paid out. The outer ends of the leading wires are then attached to the blasting machine, the operation of which explodes the charge. It is unnecessary to do any tamping in this work if the holes are filled with water. The cartridges should not be slit. The explosive to use is Red Cross Extra Dynamite $40 \%$. The following table gives the approximate charge for holes of different depths :

\begin{tabular}{c|c}
\hline Depth of Hole. & $\begin{array}{r}\text { Approximate Number of }{ }^{1 / 1} \\
\times 8^{\prime \prime} \text { Cartridges. }\end{array}$ \\
\hline $5 \mathrm{ft.}$ & 4 \\
I0 ft. & 7 \\
$15 \mathrm{ft}$. & 12 \\
$20 \mathrm{ft}$. & 17 \\
$30 \mathrm{ft}$. & 25 \\
$40 \mathrm{ft.}$ & 35 \\
\hline
\end{tabular}

Where the ground is swampy or ponds forn in the wet season only and dry up later in the year, the blasting should be done in the dry season when a raft will not be required. This blasting should be done just as described above except that it is necessary to tamp the charge thoroughly unless the borehole fills up with water. In this work it is 
sometimes of advantage to make a chamber in the bottom of the hole by first exploding a single cartridge in the bottom. This makes it possible to get more of the main charge into the bottom and break the rock or subsoil better. The explosion of the single cartridge may close the hole a little, but it can easily be opened again with the auger or an iron rod. The main charge must never be loaded immediately after chambering, but a half hour or more allowed for the bottom of the borehole to cool off. This plan of chambering the bottom may also be followed when water fills the bore holes.

As the movement of water into this hole tends to carry dissolved clay with it, which may eventually form an impervious coating over the sand or gravel at the bottom and thus stop the drainage, it is advisable to guard against this by filling the hole with coarse material immediately after the blast.

Have ready, 15 or 20 feet from the proposed hole, a pile of rubbish such as pieces of corn stalks, cotton stalks, small pieces of stump wood and a few forkfuls of hay or straw. Dump the rubbish into the blasted hole, being careful not to clog it. Poke it down with a pole, then put the hay or straw on top, filling in the last few feet with heavy chunks of earth. Such a filled hole should establish permanent drainage.

See pages 119 to 126 for proper methods of priming, cliarging, tamping and firing.

\section{Road Building}

Road grading and ditching always take more or less digging, but by using dynamite to loosen up the hard ground or shale, and to blast out the rock, roads can be built quickly and at reduced-expense.

To blast cuts not more than five feet deep through hard earth or shale a bar should be driven down to grade and two or three $11 / 4 \times 8$-inch cartridges of Red Cross Extra Dynamite $40 \%$ exploded in the hole thus made. Be sure to first tamp the charge properly. Holes should be spaced five to eight feet apart. In this way the material to be removed is not only broken up so that it can be shoveled very easily, but a good portion of it is spread over the surrounding land and does not have to be handled.

Roads can be ditched with but little shoveling, by exploding about half a cartridge of the same kind of dynamite in holes along the sides a foot deep and two to three feet apart.

If it is necessary to cut through rock, the holes slould be drilled closer together and charged heavier. See pages 119 to 126 for proper methods of priming, charging, tamping and firing. 


\section{Excavating Cellars}

If the work is in rock, drill the holes four feet deep and two and a talf to three feet apart. Charge with one or one and a half $1 \frac{1}{4} \times 8$-inch cartridges of Red Cross Extra Dynamite $40 \%$. As hand drills are not often larger than one inch in diameter, it will be necessary to pour the dynamite out of the shells and pack it in the bottoms of the holes with a wooden stick exactly as when blockholing a boulder as already described. The priming and tamping are also done as when blockholing boulders. After one cut or bench has been taken out in part or over the entire surface of the cellar or trench, the second cut of three or four feet may be commenced and the excavating continued in this way until the proper depth is reached.

When the cellar foundations are to be in earth or shale the blasting is done as in road grading already described. A small shallow cellar not larger than fifteen by twenty feet nor deeper than four feet can be economically excavated in earth almost entirely and with practically no shoveling by drilling holes three feet apart each way, and three feet nine inches deep and loading in each hole two $11 / 4 \times 8$-inch cartridges of Red Cross Extra Dynamite 20\%. The explosion spreads practically all of the material excavated over the adjacent ground for some distance.

The charges should each be primed with an electric fuze, should be well tamped, and all exploded together with a Reliable Blasting Machine. See pages 119 to 126 for proper methods of priming, charging, tamping and firing.

\section{Sinking Wells}

Wells are generally sunk through rock or ground which cannot be dug to advantage without the aid of explosives. In well sinking when rock is reached and the earth or sand above is properly supported, a circle of four or five drill holes should be started about half-way between the center and the sides of the well and pointed at such an angle that they will come closer together near the center when they are three or four feet deep. These holes should be loaded about half full of Red Cross Extra Dynamite $40 \%$, with damp clay or sand tamping packed firmly above to the top of the hole and then exploded all together from the-surface by electricity. The result of this shot will be to blow out a funnel-shaped opening in the center, and the bottom can then be squared up with another circle of holes drilled straight down as close to the sides as possible. If the well is large it may be necessary to drill a circle of holes between the inner and outer circle. The above process should be repeated until the well has passed through the rock or has been sunk to the necessary depth. Do not in any case enter a well until all the fumes of the last blast have come out. If in doubt, lower a lighted candle to the bottom, if it continues to burn the well may be entered safely. See pages 119 to 126 for proper methods of priming, charging, tamping and firing. 


\section{Digging Post Holes}

Only enough dynamite slould be used in this work to make the digging easy because larger charges loosen the ground to such an extent that it is difficult to make the poles or posts as firm as they should be. This applies particularly to large poles.

To do this blasting a hole is bored into the ground within 6 inches of the desired depth of the hole. In the bottom of this hole from onequarter to a whole cartridge of Red Cross Extra Dynamite $40 \%$ is exploded. No tamping should be done as this would cause the dynamite to loosen the surrounding ground too much.

\section{Shattering Subsoil and Hardpan}

Plowing and cropping the same soil year after year robs the topsoil of many of its original crop-bearing properties. Deep plowing as a rule is the remedy for soil deterioration. When a subsoil plow is used a noticeable increase in the crops is obtained although the soil is only indifferently broken up to a maximum depth of 18 inches. How much more then may be expected if 4 or 5 feet of virgin soil is rendered porous and mellow! Red Cross Extra Dynamite accomplishes this, as it thoroughly breaks up and shatters the hardpan, or hard impervious clay to this depth. It aerates same and places at the disposal of plant life an enlarged moisture reservoir and all the soluble fertilizing mineral elements contained in that virgin ground.

In doing this work the greatest efficiency is obtained by boring holes at intervals of 15 to 20 feet to a depth of 3 to 4 feet according to thickness of the clay subsoil. Each hole is charged with one-half of a $11 / 4 \times 8$-inch cartridge of Red Cross Extra Dynamite $20 \%$, primed with cap and fuse. After the charge is placed, holes are tamped as compactly as possible up to the surface. The tighter the tamping is done the better will the results be and it is very important that this be done properly in order to minimize as much as possible the effect of the explosion on the surface soil. See page 122 .

When blasting hardpan the holes should be bored to within about six inches of the bottom of the hardpan and the charge of dynamite placed at that point, the object being to shatter the greatest area possible and not to merely make a chamber in the ground under the hardpan. The spacing of holes should be somewhat closer and charge of dynamite should be somewhat heavier than when blasting ordinary subsoil. When the hardpan is thin, six to twelve inches, the charge should be not more than half a cartridge placed in the middle of the hardpan. 
In some kinds of hardpan, like cemented gravel, it may be necessary to vary a little the instructions given above. These instructions will, however, answer for a guide until practice shows that some slight changes in the way of blasting these irregular hardpans will prove of advantage. If properly done, it may not be necessary to blast subsoil or hardpan more often than once in ten years. In orchards in California hardpan, heavier charges are sometimes used in the boreholes so that the blast will leave a considerable opening, which can be filled with special fertilizers. Subsoil blasting should be done only when the ground is dry because wet subsoil is not easily cracked and shattered, and tends to come up on top, leaving a large hole where each blast was fired.

\section{Tree Planting}

The method to be employed in cloing this work is to punch a hole in the ground at the point selected for planting the tree, to a depth of two to five feet according to nature of soil, and location of hardpan, if any.

In very tight soils, as in California hardpan a whole cartridge of Red Cross Extra $20 \%$ or even $40 \%$ may be necessary. These heavy charges should be tamped.

The usual charge is one-half cartridge of Red Cross Extra Dynamite $20 \%$ per hole, primed with cap and fuse. If the soil in which the tree is to be planted is of a hardpan, shale or very compact clay, holes should be tamped, as also in the case when pecan trees are planted, otherwise no tamping is necessary.

The common practice is to plant the trees shortly after the holes are blasted. Some orchardists, however, believe best results will be obtained when holes for Spring planting are blasted in the Fall.

This affords about six months time for the air, moisture and sunlight to work on the subsoil and mellow it.

If trees are planted immediately after the blast, care must be taken to poke down the upheaved soil at the bottom of the hole or settle it well with water. If this is not done, the dirt may shrink away from the roots of the tree, leaving is suspended in air or water and thus killing it. This is undoubtedly the cause of the death of the few dynamite-set trees reported as failures. A little care in settling the dirt will prevent this trouble.

\section{Table of Charges and Amount of Red Cross Extra Dynamite 20\% Required per Acre for Planting Trees}

\begin{tabular}{|c|c|c|c|c|}
\hline $\begin{array}{c}\text { Distance between } \\
\text { trees, } \\
\text { square method. }\end{array}$ & $\begin{array}{c}\text { Trees } \\
\text { per acre. }\end{array}$ & $\begin{array}{l}\text { Amount of } \\
\text { dynamite per acre, } \\
\text { using } \frac{1}{2} \text { cart. } \\
\text { per tree. }\end{array}$ & $\begin{array}{l}\text { No. } 6 \\
\text { Blasting Caps, } \\
\text { per acre. }\end{array}$ & $\begin{array}{c}{ }^{*} \text { Fuse per acre, } \\
2 \frac{1}{2} \mathrm{ft} . \\
\text { per tree. }\end{array}$ \\
\hline $15 \mathrm{ft}$. & 196 & 49 lbs. & 196 & $490 \mathrm{ft}$ \\
\hline $20 "$ & IIO & 28 & IIO & 275 “ \\
\hline $30 "$ & 49 & 13 " & 49 & $122 "$ \\
\hline $40 "$ & 25 & 7 " & 25 & $63 "$ \\
\hline
\end{tabular}

* It is necessary to have as many feet of fuse per hole as the hole is deep. 


\section{Cultivating or Rejuvenating Old Fruit Trees, Grape Vines, Etc.}

The principal objects to be attained by using dynamite in cultivating or rejuvenating old fruit and other trees, grapevines, etc., is to open up the subsoil so that the roots may spread farther and go deeper and also so as to increase the waterholding capacity of the soil, to prevent the surplus moisture from lying on or near to the surface. This work is, therefore, very much like subsoil or hardpan blasting, especially in such places where resistant soil conditions are encountered.

In California and other States, where many orchards grow over hardpan, holes are often drilled from 3 to 5 feet deep and sometimes placed only 6 feet away from the trees. When holes are within 6 feet of the trees, the charge is reduced.

It is not often advisable to blast with large charges or so close to the tree that many of the roots will be broken. When this occurs it is necessary to prune the top of the tree so that the transpiration will properly correspond with the feeding. Do not fail to carry out the priming, charging and tamping instructions as contained on pages 119 to 126.

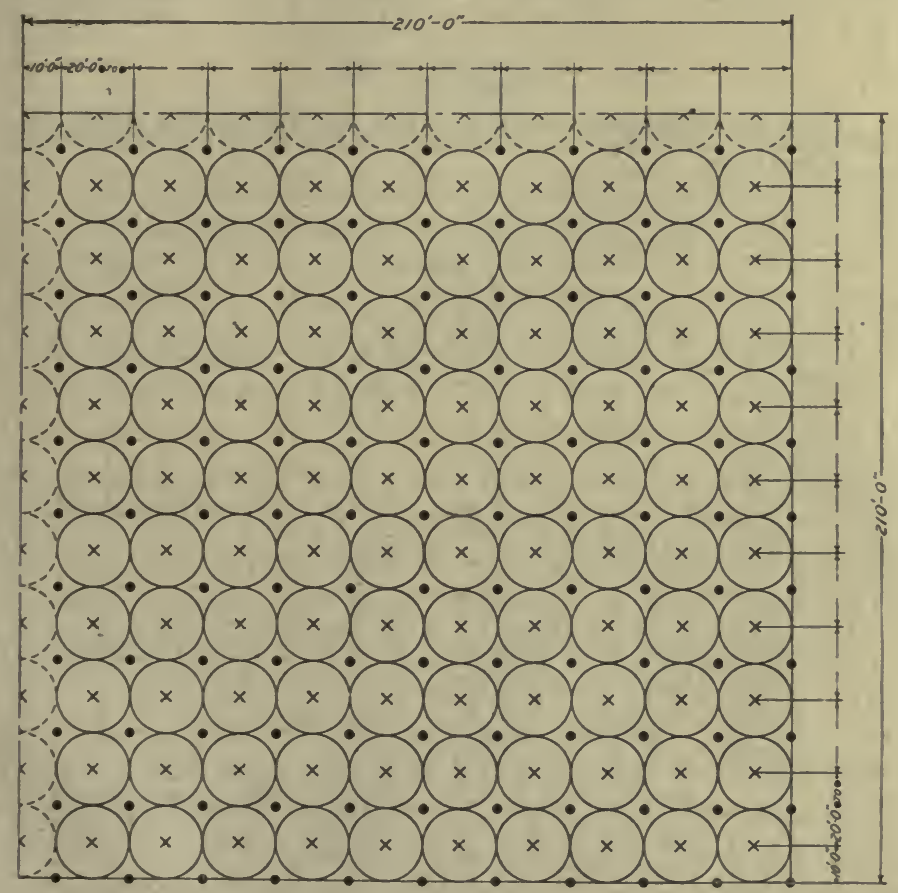

FIG. 133

This diagram represents a square acre, approximately, with trees growing at 20 feet distances " on the square." The black dots represent the trees, the crosses the blasts, and the circles the areas broken by the blasts. This system, with holes punched in the centers of the squares is the best when trees are spaced up to twenty feet apart. As 20 -feet spacing does not exactly cover a square acre half the effect of the blasts on two sides of the acre will be in the two adjacent acres. 


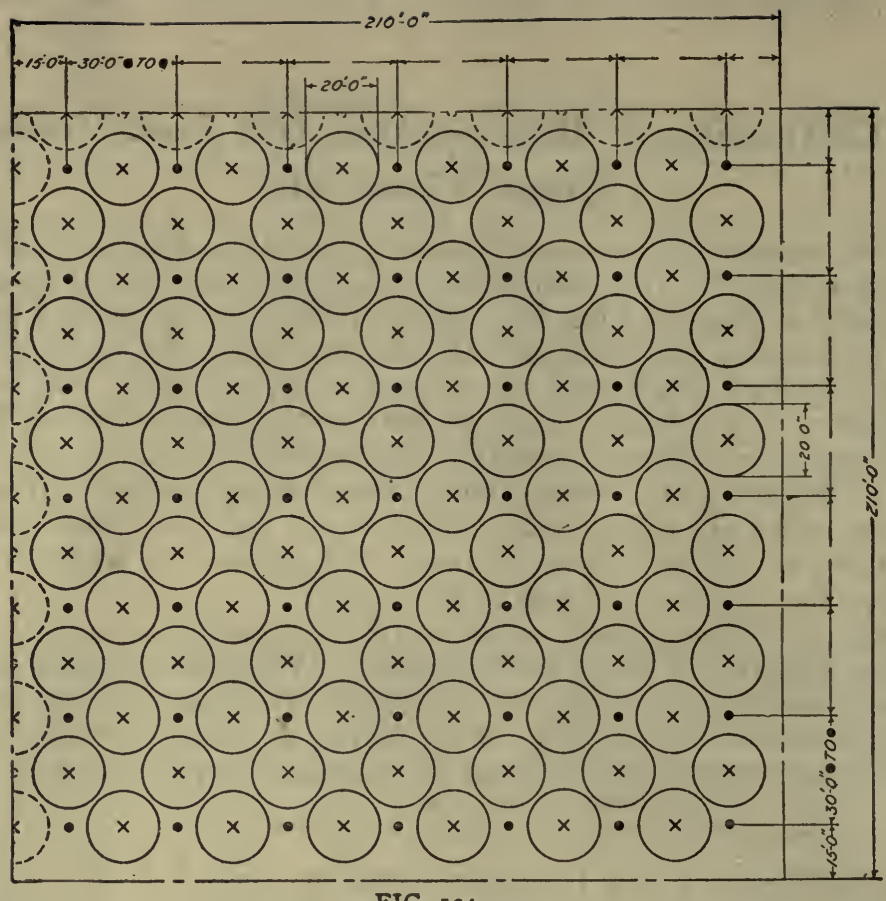

FIG. 134

This represents a square acre of orchard set on the 30 feet square plan. with blasts between the trees. This system is best where trees are from 20 to 30 feet apart.

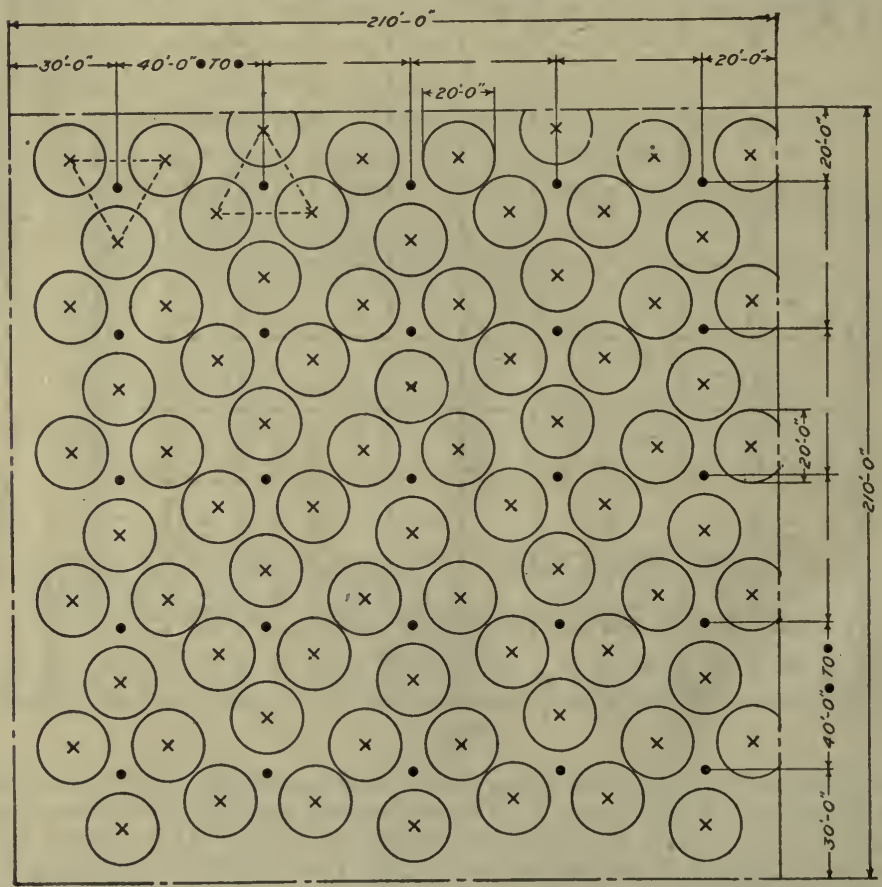

1.1U. 135

This represents a square acre of orchard set on the 40 feet square plan, with blasts on three sides of each tree. The holes are punched at the apexes of an equilateral triangle, the tree being in the center and the apexes at ro feet distances from the tree. As shown, the triangles for two adjacent rows should point in opposite directions to distribute the blasting to best advantage. This method is best when trees are more than 30 feet apart. 
Table of Charges and Amount of Red Cross Extra Dynamite

\section{Required per Acre for Orchard Rejuvenation}

\begin{tabular}{|c|c|c|c|c|}
\hline $\begin{array}{c}\text { Distance } \\
\text { between } \\
\text { trees, } \\
\text { square } \\
\text { method. }\end{array}$ & $\begin{array}{l}\text { Trees } \\
\text { per } \\
\text { acre. }\end{array}$ & Location of holes for Dynamite. & $\begin{array}{l}\text { Number of } \\
\text { holes } \\
\text { per acre. }\end{array}$ & $\begin{array}{l}\text { Pounds of } \\
\text { Red Cross } \\
\text { Extra } \\
\text { Dynamite } \\
\text { per acre } \\
\text { using } \\
\text { Cartridge } \\
\text { per hole. } \\
\end{array}$ \\
\hline $\begin{array}{l}\text { I } 5 \mathrm{ft} \text {. } \\
20 \mathrm{ft} \text {. }\end{array}$ & $\begin{array}{l}196 \\
\text { I } 10\end{array}$ & Midway between on diagonal lines. & $\begin{array}{l}198 \\
\text { I } 10\end{array}$ & $\begin{array}{l}49 \\
28\end{array}$ \\
\hline $\begin{array}{l}20 \mathrm{ft} . \\
30 \mathrm{ft} \text {. }\end{array}$ & $\begin{array}{r}\text { I IO } \\
49\end{array}$ & Midway between on square lines. & $\begin{array}{r}210 \\
91\end{array}$ & $\begin{array}{l}53 \\
23\end{array}$ \\
\hline $\begin{array}{l}30 \mathrm{ft} . \\
40 \mathrm{ft} .\end{array}$ & $\begin{array}{l}49 \\
25\end{array}$ & Ten feet from tree on three sides. & $\begin{array}{r}147 \\
75\end{array}$ & $\begin{array}{l}37 \\
19\end{array}$ \\
\hline
\end{tabular}

\section{Blasting Ice}

Ice gorges may often be prevented by shattering the large floating cakes with Red Cross Extra Dynamite $40 \%$ so that they will not lodge at dams or in the narrow parts of the stream. To break these cakes several cartridges of the dynamite tied together in a bundle are laid on the ice and exploded. This is repeated until the cake is thoroughly shattered and broken up. The size of the charge and the number of times the blasting must be repeated depend altogether on the thickness of the ice and the size of the cake. One cartridge of the bundle is primed with blasting cap and fuse, but before this the clynamite must be thoroughly thawed and kept thawed untii it is laid on the ice. This blasting can be done best along broad, slow-moving parts of the stream where it is easy to get on to the ice cakes either from the shore or from boats. When the streams are narrow the charges of dynamite may be thrown on to the ice from the shores, or, if the ice is running swiftly, they may be dropped on to the cakes from the downstream side of bridges. When the charges consisting of two or more cartridges tied together in a bundle are to be thrown on to the floating ice either from bridges or the shore a block of wood, piece of board or something of that kind should be tied to the charge to keep it from rolling out of position after it lands on the ice. As it is necessary when blasting ice in this way to light the fuse while the dynamite is in the hands of the blaster, particular attention must be given to having the fuse plenty long enough and the charge must be thrown just as soon as the fuse is lighted. 
The following table gives the approximate quantity of Red Cross Extra Dynamite $40 \%$ required to break floating ice cakes of different thickness when the dynamite is exploded on the surface of the ice. The number of charges necessary depends on the size and extent of the ice cake :

\begin{tabular}{c|c}
\hline $\begin{array}{c}\text { Thickness of Ice } \\
\text { Cakes. }\end{array}$ & $\begin{array}{c}\text { Approximate No. of } \\
\text { Cartridges. }\end{array}$ \\
\hline I 2 in. & 2 to 3 \\
$24 \mathrm{in.}$ & 6 to 8 \\
$36 \mathrm{in.}$ & 10 to 12 \\
\hline
\end{tabular}

To open ice gorges already formed, a channel should be cut through them beginning on the down-stream side and working up stream along the line of the strongest current. In large streams this channel should be about fifty feet wide, and if the gorge does not move after the channel has been cut through, it will then be necessary to begin at the downstream side of the gorge again and widen the channel until the ice has been carried away.

To make the channel, holes are cut with an axe, bar or ice spade through the ice twenty to thirty feet apart. These holes are laid out in a semi-circle with the two end holes about twenty to thirty feet back frnm the open water and fifty feet apart.

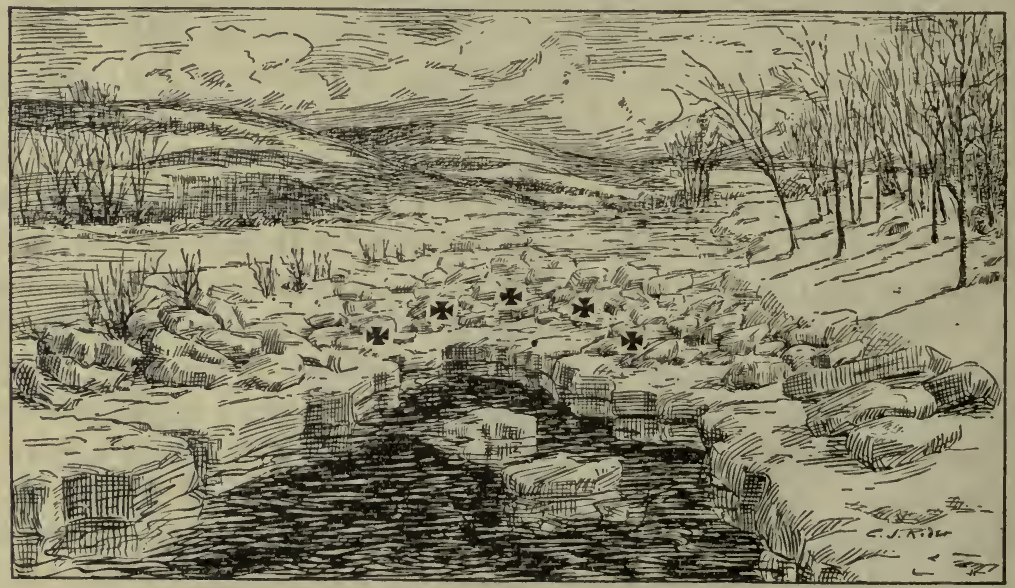

FIG. 36.-DIAGRAM SIIOWING LOCATION OF ROW OF HOLES FOR BLASTING AN ICE GORGE 
The charge consists of several 1 1 $\frac{1}{4} \times$ S-inch cartridges of Red Cross Extra Dynamite $40 \%$, tied sécurely together with string, one of the cartridges having been primed with a Victor Waterproof Electric Fuze. When the charges for all of the holes are prepared they are connected together and to the leading wires. Each charge is then lowered by the electric fuze wires into the water and pushed under the down-stream ice with the tamping stick. If the current is strong enough to carry the charge down stream the electric fuze wires should be long enough to let it float six or eight feet below the holes. In a slow current a block of light wood may be fastened to each bundle of cartridges to make it float against under side of ice. The explosion of all of these charges simultaneously by the operation of the blasting machine will break up the first fifty or sixty feet of the channel and the broken ice will immediately float away unless the current of the stream is very sluggish. In that case the broken ice should be pushed out with poles into open water, before it has time to freeze in place again. This same operation is repeated cutting out fifty or sixty feet or more of the channel with each blast until the gorge has been cut through. If the ice is from two to four feet thick the charge in each hole should be from two to five $11 / 4 \times 8$-inch cartridges of Red Cross Extra Dynamite $40 \%$. In ice six ta eight feet thick, each charge must be increased to ten or twelve cartridges. When the ice is thick, and large charges are necessary, the holes have to be from six to twelve inches in diameter in order to get the bundle of cartridges through them. These large holes can be cut through the ice more easily by exploding half cartridges of the dynamite in small holes made with bars.

In this work particular attention should be given to having the dynamite in a well-thawed and soft condition when it is used, and to guard against breaking insulation of fuze wires or withdrawal of fuzes by the pull of the current.

Ice is blasted from watering places for stock either by exploding the dynamite on the ice or in the water under the ice. See pages 119 to 126 for proper methods of priming, charging, tamping and firing.

\section{Starting Log Jams}

To start log jams with dynamite the charge of several cartridges or in some instances of many pounds of dynamite is exploded on or under the logs forming the key of the jam. When small charges are enough, the cartridges are tied in a bundle as when blasting ice. If charges of fifty pounds or more are necessary the dynamite may be put in a bag or left in the original wooden cases. The charge is primed with a Victor Waterproof Electric Fuze and after being firmly secured in the proper position is exploded from the shore with a blasting machine.

Blocks in log rollways caused by rain and snow freezing and binding the logs together are broken up by exploding charges of dynamite in different places under the logs until they are loosened and can be rolled apart.

Red Cross Extra Dynamite $40 \%$ is recommended for starting log jams and for opening the rollways. See pages 119 to 126 for proper methods of priming, charging, tamping and firing. 


\section{WHAT TO DO WHEN WANTING DYNAMITE}

In the foregoing, Red Cross Extra Dynamite and Du Pont Blasting Supplies have been carefully described, and the way to store and use them explained. When blasting is contemplated refer to the section on the kind of work to be done and find the kind of dynamite recommended for that work and about how much will be required.

If the dynamite is to be used for blasting stumps, multiply the number of stumps to be blasted by the number of cartridges for a stump the size they will average and divide the number of cartridges by two to get the number of pounds required.

We prefer to sell through local dealers when possible. If we have a representative in your locality carrying stock, your order will be forwarded to him to be filled from his own stock. If we have no dealer nearby, we shall make shipment from our nearest distributing point, and if it is to be a charge account, the goods will be invoiced to the storekeeper who has agreed to carry your account, but shipment will be made direct to you.

You can buy any quantity of dynamite from one cartridge up from local dealers who have stock on hand, but on orders sent to this Company for direct shipment, broken lots cannot be purchased. The smallest direct shipment that we can accept for dynamite is 25 pounds; for caps, 100; for fuse, 100 feet. Orders for larger quantities must be in multiples of these figures; for instance, 50, 75, 100 and upwards pounds of dynamite; $100,200,300$, etc., caps; $100,200,300$, etc., feet of fuse.

The minimum freight charge is on the basis of 100 pounds; hence freight will be the same on $25,50,75$ or 100 pounds.

As soon as you have sent in an order, be sure to notify your local freight agent, so that he may advise you promptly of the arrival of the shipment. It is required by law that explosives be removed from freight stations within 48 hours after their arrival. Order about 3 to 4 weeks before you need the dynamite and supplies.

\section{Tear Out and Fill In Opposite Page When Ordering Supplies}

It is best to do this whether you can get them from your local dealer or not. Many of our dealers do not carry Blasting Supplies in stock, but will see that your order is filled. They need this written order. Even if the dealer carries a stock of Blasting Supplies, it is a great convenience for him to have this written order, and tends to prevent errors or omissions.

If we have no dealer in your locality send us the order and remittance and we will see that you are supplied.

$$
\begin{aligned}
& \text { E. I. du PONT de NEMOURS POWDER CO., } \\
& \text { Wilmington, Del. }
\end{aligned}
$$




\section{Professional Blasters Can Find}

\section{Profitable Employment on Farms}

We should like to hear from men with blasting experience in mines, quarries or with contractors, etc.; also from inexperienced men willing to learn blasting.

Men having leisure time on their hands at certain seasons of the year can obtain profitable employment from farm owners and fruit growers who have land to clear of stumps and boulders, ditches to be dug, ponds and low spots to drain, trees to plant or cultivate, roads to make, or fields to subsoil.

Hundreds of men scattered all over the United States are making a very good living by devoting their time to work of this kind, but there are not nearly as many men engaged in it as are necessary to take care of all of the work to be had.

We do not employ agricultural blasters, but we do everything in our power to assist those who take up the work to secure blasting contracts from parties in their locality who have replied to our extensive advertising. The parties employing them pay them for their work. We also give agricultural blasters attractive handbills and posters, advertising their business, and letterheads and envelopes, booklets and other printed matter which, when properly distributed and used, assist them in securing work.

BLASTER CARO

\section{IF YOU WANT TO TAKE UP AGRICULTURAL BLASTING-CUT OUT, FILL IN AND MAIL THIS CARD}

E. I. du Pont de Nemours Powder Co.,

Wilmington, Del.

Gentlemen-Please explain how I may become an agricultural blaster and how you will help me secure work at blasting from farmers in my neighborhood.

Name

St. \& No. or R. F. D 
Mr. Thomas $\mathrm{H}$. Benton, of Tennessee, explains below his methods of securing blasting contracts:

"My attention was first called to the agricultural uses of dynamite by a friend and neighbor, named C. R. Johnson, who employed me to subsoil two acres of land. I had no one to instruct me, obtaining all my knowledge and instructions from the Du Pont Company's Farmer's Handbook, which I studied closely. I was very successful in the subsoiling and other little jobs.

"The next thing I did was to co-operate with our jobber, Levi, Joy \& Co. Right at this point is where I must give much credit for my success. Knowing the interest the jobber was taking in me and even sharing part of the expense on some local ads which I got up, I at once got busy and had some individual printing done. I bought a horse and spring wagon, tools for blasting, etc., a small stock of dynamite and went out among the farmers. My wagon is painted red and lettered nicely, (Du Pont) Red Cross Extra Dynamite, Agricultural Demonstrator and Salesman. And say! the farmers take their hats off to me. Work! Why I can hardly keep up with the contracts. I have several large contracts on hand for later dates, among which is a job of ditching in the Mississippi Delta. Where the other man buys the dynamite and supplies, I work for $\$ 5.00$ per day and all expenses. I will say that the best way to be able to figure on a certain work is to let the other fellow buy the material and work by the day for others until experience helps a blaster on estimating prices, etc. I can figure almost to the stick required on most work.

"I won't explain in detail everyone I have worked for, but I have just completed a three days' stump-blasting job, 20 miles north of this city, for a man named Cummins. He is making a model farm of his property and I figured on 200 old stumps, only ten bad ones in the lot. I furnished the dynamite and did the work for $\$ 64.60$, used 250 lbs. 40 per cent., 400 feet fuse, 2 boxes caps. He was so well pleased with my work that he gave me $\$ 5.00$ extra money, a $\$ 15.00$ white Orpington cock, a setting of fine eggs and a side of meat. As I have a family, of course I appreciated all these things. Each day I was there several people came to see me work and I actually believe I could keep busy all spring in that neighborhood. Have closed several small contracts to hold me for awhile,

"I am glad to say that Agricultural Blasting puts a man in touch with the very best people in the country."

The above should prove encouraging to every Agricultural Blaster. Mr. Benton has been successful not because he was an experienced solicitor, nor because he was an experienced blaster at the time of taking up this proposition. In fact, he was a plain everyday farmer who had never done any soliciting for contracts of any kind and whose only knowledge of the use of dynamite to begin with was obtained from our Farmer's Handbook of Explosives. His success, therefore, has been due altogether to his own energetic and intelligent efforts. The first good move he made was to form a business connection with our dealer in his locality. That is something every blaster ought to do. This dealer has been of assistance to Mr. Benton in securing work. For the main part, however, his success has been due to energetic hustling. below.

For further information on this subject, tear out, fill in and mail the card
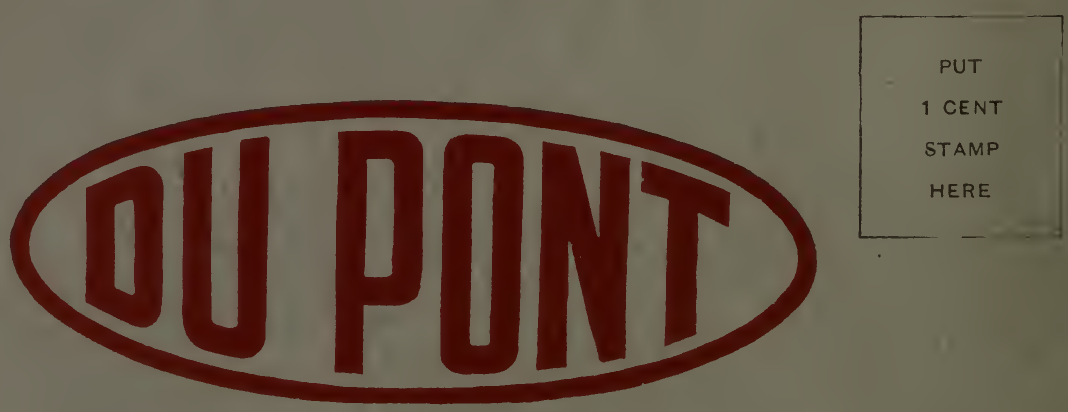

MGR. AGRICULTURAL DIVISION, 
$\rightarrow$

$$
\text { - }
$$


THIS BOOK IS DUE ON THE LAST DATE STAMPED BELOW

AN INITIAL FINE OF 25 CENTS WILL BE ASSESSED FOR FAILURE TO RETURN THIS BOOK ON THE DATE DUE. THE PENALTY WILL INCREASE TO 50 CENTS ON THE FOURTH DAY AND TO \$1.00 ON THE SEVENTH DAY OVERDUE.

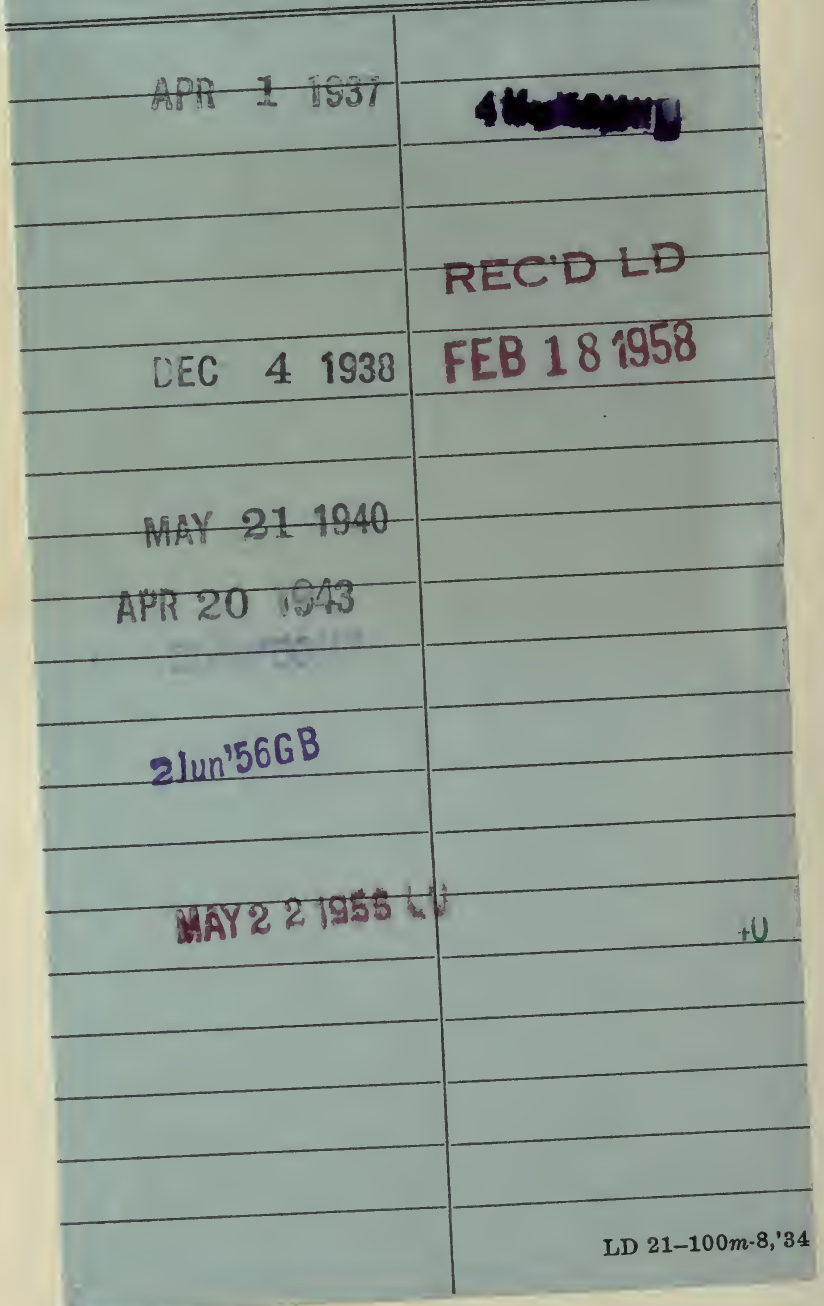




\section{YC $\quad 11933$}

ᄀ

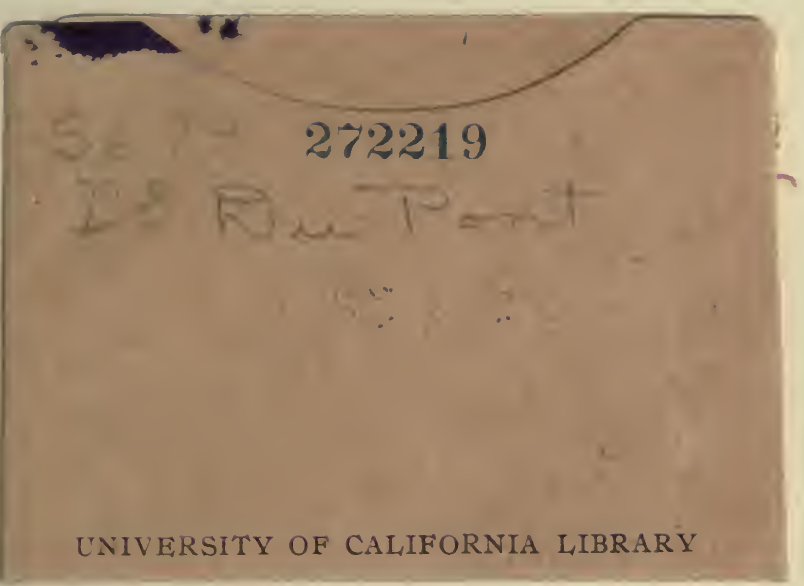


